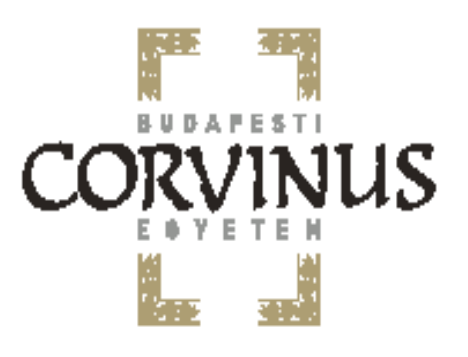

Szociológia Doktori Iskola

\title{
MÉDIA MULTITASKING
}

Az új generációk megváltozó médiafogyasztási és kommunikációs szokásairól

Ph.D. értekezés

C Székely Levente

Témavezető:

Gálik Mihály, CS.c

Budapest, 2013 


\section{TARTALOM}

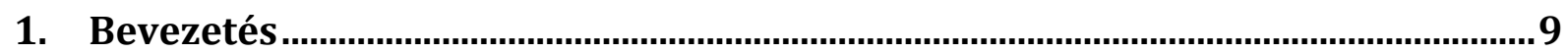

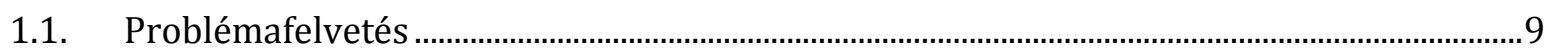

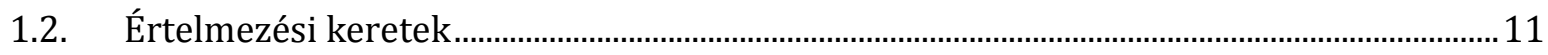

2. Elméleti megközelítések...................................................................................14

2.1. Az egyidejü többcsatornás kommunikáció és médiafogyasztás fogalma ................................... 14

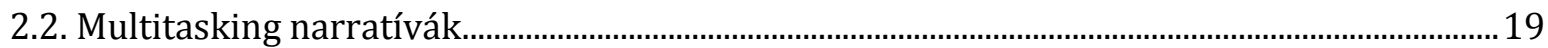

2.3. (Média és kommunikációs) multitasking modellkísérlet................................................................53

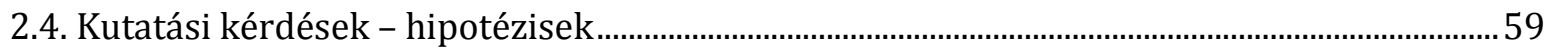

3. A média és kommunikációs multitasking kutatás nemzetközi eredményei.... 62

3.1. Nemzetközi hozzáférési és használati statisztikák...................................................................... 62

3.2. Átalakuló médiafogyasztási és kommunikációs szokások ...................................................64

3.3. Média és kommunikációs multitasking sajátosságai ............................................................. 71

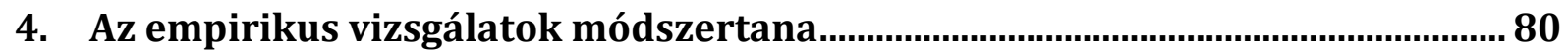

4.1. Az empirikus vizsgálatok környezete és tematikája ................................................................. 82

4.2. Az elemzés és a hipotézisvizsgálat módszerei......................................................................... 94

\section{5. Újabb lépések az egyidejű többcsatornás kommunikáció és médiafogyasztás}

kutatásában ...................................................................................................................107

5.1. Médiafogyasztási és párhuzamos fogyasztási trendek ………….......................................... 107

5.2. Generációs és életkori hatások ………………......................................................................... 133

5.3. A multitasking kognitív rendszerre gyakorolt hatása ............................................................ 154

5.4. Rekreációs és erőforrás-bővítő tevékenységek …………………………………………….... 157

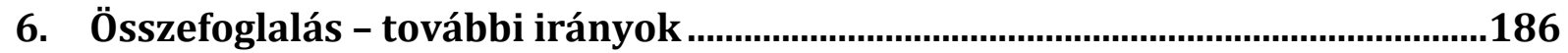

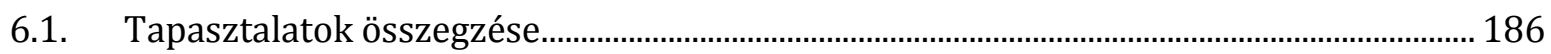

6.2. Hipotézisek vizsgálatának eredményei .................................................................................. 189

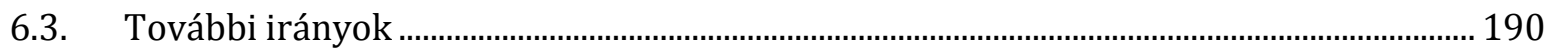


1.1. Tanulmányok, monográfiák 195

1.2. Jelentések, online cikkek. 206

8. Függelék

\section{TÁBLÁZATJEGYZÉK}

\section{Táblázatok a fószövegben}

1. táblázat: Hasonlóságok és különbségek a szocializációs közegekben (Forrás: Nagy - Trencsényi, 2012)

27. oldal

2. táblázat: Tanulók és tanárok kulturális jellemzői (Forrás: Bessenyei, 2007)

49. oldal

3. táblázat: A 16-24 évesek és a felnőtt társadalom jellemzői (UK) (Forrás: Hulme, 2009)

66. oldal

4. táblázat: A Multitasking az USA-ban (Forrás: Lawler, 2010)

67. oldal

5. táblázat: A médiafogyasztás és -kitettség változása 1999-2004 (Forrás:

Roberts - Foehr, 2008)

72. oldal

6. táblázat: A 12-18 évesek multitasking szokásai az USA-ban (Forrás: Foehr, 2006)

7. táblázat: Az televízió használata más médiumokkal (Forrás: Foehr, 2006)

75. oldal

8. táblázat: Az instant messenger (IM) használata más (Forrás: Foehr, 2006)

75. oldal

9. táblázat: Az e-mail használata más médiumokkal (Forrás: Foehr, 2006)

76. oldal

10. táblázat: A webes böngészés használata más médiumokkal (Forrás:

Foehr, 2006)

76. oldal

11. táblázat: Elsődleges és másodlagos tevékenységekkel töltött idő (óra/hét; N=96) (Forrás: Kenyon, 2008)

78. oldal

12. táblázat: Multitasking mértéke az elsődleges tevékenységekre fordított idő során (N=86) (Forrás: Kenyon, 2008)

78. oldal

13. táblázat: Többet tud-e multitaskingolni az alábbi tevékenységek végzése mellett, ha online végzi azokat (Forrás: Kenyon, 2008)

79. oldal

14. táblázat: Az adatfelvételekbe került évfolyamok a különböző kutatásokban

103. oldal

15. táblázat: Néhány európai ország médiafogyasztása; óra/hét (Forrás: WIP, 2009)

108. oldal

16. táblázat: 2001-2002-es médiafogyasztási tipológia (Forrás: Pintér, 2004; 111. oldal 
WIP, 2001-2002)

17. táblázat: 2009-es „hagyományos” médiafogyasztási tipológia (Forrás: WIP, 2009)

113. oldal

18. táblázat: 2009-es, internettel bővített médiafogyasztási tipológia (Forrás: WIP, 2009)

113. oldal

19. táblázat: Médiafogyasztás mennyisége multitasking gyakorlata szerint (N=1338; WIP, 2007)

118. oldal

20. táblázat: Felhasználói tudás és multitasking korcsoportok szerint (Totál százalékok, N=1349; Forrás: WIP, 2007)

129. oldal

21. táblázat: Varianciaanalízisek eredménye

150. oldal

22. táblázat: Médiafogyasztási generációk

151. oldal

23. táblázat: Életkori és generációs varianciaanalízisek eredménye

151. oldal

24. táblázat: Az internetezés célja a diákok és a szülők szerint $\left(\mathrm{N}_{\text {szülő }}=754\right.$,

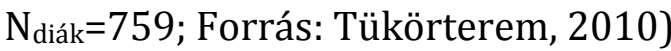

172. oldal

25. táblázat: Az internetezés céljai nemek szerint $\left(\mathrm{N}_{\text {szülolo }}=754, \mathrm{~N}_{\text {diák }}=759\right.$;

Forrás: Tükörterem, 2010)

26. táblázat: Hipotézisek vizsgálatának eredménye

173. oldal

190. oldal

Táblázatok a függelékben

27. táblázat: Regressziós modellek magyarázóereje

215. oldal

\section{ÁBRAJEGYZÉK}

\section{Ábrákk a főszövegben}

1. ábra: A média és kommunikációs multitasking keretei és kontextuális jellemzői

54. oldal

2. ábra: A multitasking tipizálásának szempontjai

57. oldal

3. ábra: A média és kommunikációs multitasking speciális szempontjai

58. oldal

4. ábra: Internethasználók a világban (Forrás: ITU, 2011)

62. oldal

5. ábra: Mobiltelefon-előfizetések a világban (Forrás: ITU, 2011)

63. oldal

6. ábra: Háztartások felszereltsége (Forrás: Special Eurobarometer 381, 2012)

63. oldal

7. ábra: Televízió és egyéb szabadidős elfoglaltságok trendjei az USA-ban

(Forrás: Robinson - Martin, 2009)

64. oldal 
8. ábra: Médiafogyasztás mennyisége egy átlagos napon (óra:perc, a multitaskingot nem tartalmazza) (Forrás: Dolliver, 2012)

65. oldal

9. ábra: Az új technológiákhoz kapcsolódó attitűdök (UK) (Forrás: Hulme, 2009)

66. oldal

10. ábra: TV-nézés közben másik eszköz használatának valószínűsége a 18-

44 évesek körében (Forrás: IAB, 2012)

68. oldal

11. ábra: Mobileszköz használata a televízióban látottak hatására (Forrás:

IAB, 2012)

69. oldal

12. ábra: A kedvenc műsorral kapcsolatos márka visszaidézésének

képessége (Forrás: IAB, 2012)

70. oldal

13. ábra: Televíziózást gyakran vagy néha kísérő egyéb elfoglaltságok (UK) (Forrás: Ofcom, 2007)

74. oldal

14. ábra: Az empirikus kutatássorozat folyamata és részei

81. oldal

15. ábra: Különböző médiumok fogyasztásának gyakorisága (Forrás:

WIP,2009)

109. oldal

16. ábra: Médiafogyasztási trendek [óra/hét] (Forrás: WIP, 2001-2009)

110. oldal

17. ábra: Médiumok fontossága (Forrás: WIP, 2007-2009)

115. oldal

18. ábra: Távközlési szolgáltatásokhoz kapcsolódó igényszintek (Forrás:

NHH, 2009)

116. oldal

19. ábra: Internetezés közben más médiumok fogyasztásának gyakorisága (Forrás: WIP, 2009)

117. oldal

20. ábra: Számítógépezés, internetezés közbeni hagyományos

médiafogyasztás gyakorisága ( $\mathrm{N}=1000$; Forrás: ITTK-NRC, 2008)

118. oldal

21. ábra: Végzett-e más NEM a számítógéphez kötődő tevékenységet

miközben a kérdőívet kitöltötte? (N=1000; Forrás: ITTK-NRC, 2008)

119. oldal

22. ábra: Végzett-e más a számítógéphez kötődő tevékenységet miközben a kérdőívet kitöltötte? (N=1000; Forrás: ITTK-NRC, 2008)

121. oldal

23. ábra: Média multitasking tevékenységek előfordulásának gyakorisága

(N=8000; Forrás: Magyar Ifjúság 2012)

122. oldal

24. ábra: Online multitasking tevékenységek előfordulásának gyakorisága

(N=8000; Forrás: Magyar Ifjúság 2012)

123. oldal

25. ábra: DIDIX (Forrás: WIP, 2001-2009)

125. oldal

26. ábra: Internet-felhasználói tudás (Forrás: WIP, 2007-2009)

126. oldal

27. ábra: Internet-felhasználói tudás és a multitasking gyakorlása $(\mathrm{N}=1349$;

Forrás: WIP, 2007)

127. oldal

28. ábra: Segítségnyújtás a számítógép, internet használatában (Forrás:

Tükörterem, 2010, Nszülő=754, Ndiák=759)

128. oldal

29. ábra: Internetezés közben más médiumok fogyasztásának gyakorisága korcsoportok szerint (N=1096; Forrás: WIP, 2009)

131. oldal 
30. ábra: Internetezés közben más médiumok fogyasztásának gyakorisága szubjektív anyagi helyzet szerint ( $N=1056$; Forrás: WIP, 2009)

31. ábra: A médiafogyasztás szerkezete korcsoportok szerint (Forrás: PintérSzékely, 2006; WIP, 2004)

141. oldal

32. ábra: Az egyes médiumok fontossága korcsoportok szerint (Forrás:

Székely, 2006; WIP, 2004)

142. oldal

33. ábra: Internetezés közbeni multitasking jelenléte az egyes korcsoportokban (N=1338; WIP, 2007)

145. oldal

31. ábra: MI0-100 index korcsoportok szerint (N=1000; Forrás: ITTK-NRC, 2008)

146. oldal

35. ábra: Mennyire megerőltető az Ön számára, ha különböző számítógépesinternetes tevékenységeket (online rádiózás, zenehallgatás, e-mailezés stb.) egyszerre kell végeznie? (N=978; Forrás: ITTK-NRC, 2008)

154. oldal

36. ábra: Milyen gyakran fordul elő, hogy számítógépezés, internetezés

közben a televízión nézett műsornál elveszti a fonalat? ( $N=610$; Forrás:

ITTK-NRC, 2008)

155. oldal

37. ábra: Mennyire megerőltető az Ön számára a különböző online tevékenységek mellett a televízióra is figyelni? ( $\mathrm{N}=610$; Forrás: ITTK-NRC, 2008)

155. oldal

38. ábra: Multitasking index a terhelés megítélése szerint $(\mathrm{N}=610 ; \mathrm{N}=978$;

Forrás: ITTK-NRC, 2008)

156. oldal

39. ábra: Végez-e más számítógéphez kötődő tevékenységet miközben..?

(N=1000; Forrás: ITTK-NRC, 2008)

158. oldal

40. ábra: Az online tevékenységek faktorstruktúrája

159. oldal

41. ábra: Erőforrás-bővítő és rekreációs faktorok korcsoportok szerint

(N=3025; Forrás: Magyar Ifjúság 2012)

160. oldal

42. ábra: Tevékenységekhez társuló zenehallgatás (N=1000; Forrás:

Kutatópont, 2012)

167. oldal

43. ábra: Internetezés közbeni multitasking jelenléte az egyes korcsoportokban (N=121; Forrás: ITTK-NRC, 2008)

168. oldal

44. ábra: Tanulással összefüggő tartalmak fogyasztási gyakorisága (N=759;

Forrás: Tükörterem, 2010)

174. oldal

45. ábra: Ön számára az odafigyelést igénylő tevékenységek (pl. munka, tanulás) esetén a zene inkább zavarja, vagy inkább segíti a koncentrációt? (N=1000; Forrás: Kutatópont, 2012)

185. oldal

46. ábra: Milyen gyakran szakítja meg a zene miatt az éppen végzett feladatát (pl. együtt dúdolja a dallamot a zenével, vagy az éppen hallgatott zeneszám hatására rákeres valamire az interneten)? (N=1000; Forrás:

Kutatópont, 2012)

185. oldal 


\section{Ábrák a függelékben}

47. ábra: Internetezés mennyisége (World Internet Project 2001; 2007 és Lakossági Médiafogyasztás Kutatás 2012)

209. oldal

48. ábra: Internet fontossága (World Internet Project 2001; 2007 és

Lakossági Médiafogyasztás Kutatás 2012)

210. oldal

49. ábra: Televízió-nézés mennyisége (World Internet Project 2001; 2007 és Lakossági Médiafogyasztás Kutatás 2012)

210. oldal

50. ábra: Televízió fontossága (World Internet Project 2001; 2007 és Lakossági Médiafogyasztás Kutatás 2012)

211. oldal

51. ábra: Rádióhallgatás mennyisége (World Internet Project 2001; 2007 és Lakossági Médiafogyasztás Kutatás 2012)

211. oldal

52. ábra: Rádió fontossága (World Internet Project 2001; 2007 és Lakossági Médiafogyasztás Kutatás 2012)

212. oldal

53. ábra: Újságolvasás mennyisége (World Internet Project 2001; 2007 és Lakossági Médiafogyasztás Kutatás 2012)

212. oldal

54. ábra: Újságok fontossága (World Internet Project 2001; 2007 és

Lakossági Médiafogyasztás Kutatás 2012)

213. oldal

55. ábra: Könyvolvasás mennyisége (World Internet Project 2001; 2007 és Lakossági Médiafogyasztás Kutatás 2012)

213. oldal

56. ábra: Könyvek fontossága (World Internet Project 2001; 2007 és Lakossági Médiafogyasztás Kutatás 2012)

214. oldal

57. ábra: Multitasking (World Internet Project 2007 és Lakossági

Médiafogyasztás Kutatás 2012)

214. oldal 


\section{KÖSZÖNETNYILVÁNÍTÁS}

Ez a dolgozat minden bizonnyal nem készült volna el, ha Nagy Ádám kitartó unszolására nem jelentkezem a Budapesti Corvinus Egyetem Szociológia Doktori Iskolájába köszönet neki ezért.

Köszönettel tartozom Gálik Mihálynak, hogy elvállalta a témavezetést és szakmai tanácsaival mindvégig segítette a munkámat.

Köszönöm tanáraimnak, barátaimnak és kutatótársaimnak: Csótó Mihálynak, Hajdu Miklósnak, Kolin Péternek, Lengyel Györgynek, Németh Renátának, Pintér Róbertnek, Rab Árpádnak, Urbán Ágnesnek, Z. Karvalics Lászlónak, akiktől az együtt gondolkozás és a közös munka során nagyon sokat tanultam. Hálás vagyok továbbá az Információs Társadalom- és Trendkutató Központban és jelenlegi munkahelyemen a Kutatópontban kapott támogatásért.

Köszönöm a tézistervem opponenseinek, Lőrincz Lászlónak és Nagy Rékának, de elsősorban Futó Péternek, aki több lépcsőben is hasznos kritikáival segített tovább csiszolni a dolgozatot.

Végül, de mindenekelőtt köszönöm a családomnak: feleségemnek és szüleimnek, hogy a kezdetektől támogatnak és gyermekeimnek, Aisának és Hunornak, hogy hagytak dolgozni. 


\section{BEVEZETÉS}

\subsection{PRoblémAFELVETÉS}

Doktori kutatásomban elsősorban az információs társadalomban szocializálódott fiatal generációkkal kívánok foglalkozni, koncentrálva az infokommunikációs technológiákhoz (IKT) kapcsolódó megváltozó médiafogyasztási és kommunikációs szokásaikra és annak egy jelenségére az egyidejü többcsatornás (kommunikációra és) médiafogyasztásra.

A témában végzett hazai és nemzetközi kutatások arra engednek következtetni, hogy a digitális korban szocializált generáció nem pusztán szokásaiban, de gondolkodásában, megismerési útjaiban is más, mint az azt megelőzők. Főleg a fiatalok körében tapasztalható átalakulás egyik jelensége, hogy a korábban többé-kevésbé jól elkülöníthető tevékenységek egyre inkább összecsúsznak, ezt az angol nyelvű szakirodalom „multitasking” kifejezéssel illeti. Kutatásomban ennek a párhuzamosságnak elsősorban a kommunikációs és médiafogyasztásbeli aspektusait kívánom körüljárni. Egyes kutatások bemutatják, hogy ha az egyes tevékenységekre fordított napi időt összegezzük, akkor az elvártnak tekinthető 24 óránál jóval magasabb számokat is kaphatunk. Ez a napi tevékenységekre fordított idő megítélésének szubjektivitása mellett nyilvánvalóan a párhuzamosságnak is köszönhető.

Habár a pszichológusok már régóta foglalkoznak a szimultán tevékenységek kognitív rendszerre gyakorolt hatásaival, a párhuzamos, többcsatornás médiafogyasztás és az infokommunikációs eszközökhöz kötődő digitális kommunikáció „tevékenységeinek összecsúszása" csak az utóbbi néhány évben kezdte el igazán érdekelni a kutatókat. A felfokozott érdeklődés minden bizonnyal annak köszönhető, hogy az infokommunikációs technológia egyre inkább az életünk részévé válik. Az ember és a gép konvergenciája, a technológia háziasítása (Silverstone - Haddon, 1996) számos területen megfigyelhető.

Az infokommunikációs technológia nem csak arra biztosít széleskörü lehetőséget, hogy különböző médiatartalmakat fogyasszunk és különféle felületeken kommunikáljunk barátainkkal, vagy akár ismeretlenekkel, hanem egy olyan egyéni módon 
paraméterezhető digitális ökoszisztéma részesei lehetünk (vagy már azok is vagyunk), amelyben a tartalomfogyasztás és a kommunikáció szimultán módon zajlik.

A kutatási kérdéseim ugyan nem számítanak korunk társadalmának alapvető kérdései közé, mégis egy olyan, az információs társadalmat átható jelenséggel foglalkoznak, amelynek megértése számos terület alapvetéseit változtathatja meg. A munkám központi tematikáját jelentő egyidejű többcsatornás kommunikáció és médiafogyasztás terjedése alapvetően befolyásolja a tartalomfogyasztást, ami a tartalom előállítói és az eszközfejlesztők számára jelent olyan új kihívást, ami válaszolni kell pl. új, a multitaskingra alkalmas eszközökkel, vagy a figyelmet megtartó tartalmakkal.

A párhuzamosság továbbá a tartalom-előállítók és átadók szervezett tereiben is jelen van, így az oktatási rendszerben is. Az oktatáshoz hasonlóan a munka világában is fontos a párhuzamos tevékenységek terjedése, mindkét esetben elsősorban a hatékonyság kérdésével összefonódva. Kulcskérdés, hogy a multitasking rontja-e az iskolai, vagy a munkateljesítményt, és egyáltalán milyen stratégiával kell közelíteni a szimultán feldolgozás felé, pl. a tartalmak hangolásával a megismerés jellegzetességeihez, vagy éppen az alternatív ingerek kiszűrésével?

Kutatásomban válaszokat keresek arra, hogy mit jelent ez a párhuzamosság a különböző tevékenységeinkben, legyenek azok olyan, elsősorban szabadidős elfoglaltságok, mint a médiafogyasztás, vagy kötődjenek olyan tevékenységekhez, mint a tanulás, vagy a munka világa. Vizsgálom a párhuzamos fogyasztás életkori és más szociodemográfiai jellemzők szerinti jellegzetességeit, illetve a multitasking folyamatait elsősorban a fiatal médiafogyasztók körében. 


\section{2. ÉRTELMEZÉSI KERETEK}

Az értekezés első bekezdésében megfogalmazott szándék azaz, hogy „elsősorban az információs társadalomban szocializálódott fiatal generációkkal kívánok foglalkozni, koncentrálva az infokommunikációs technológiákhoz (IKT) kapcsolódó megváltozó médiafogyasztási és kommunikációs szokásaikra és annak egy jelenségére az egyidejü többcsatornás (kommunikációra és) médiafogyasztásra” mindenképpen magyarázatra szorul.

A doktori kutatásomban használt legalapvetőbb fogalmak egyike az információs társadalom ${ }^{1}$. Az ipari társadalmak után kifejlődő új szerkezet, amelyet Daniel Bell posztindusztriális társadalomnak (Bell, 1973), vagy Manuel Castells információs társadalomnak (Castells, 2005) nevez az egész világot érintő és átható a napjainkban is zajló gazdasági - társadalmi - kulturális átalakulás².

Az információs társadalmi átmenet leglátványosabb megmutatkozása kétségtelenül az infokommunikációs technológiák így a számítógép, a mobiltelefon, az internet, stb. megnövekedett szerepéhez kapcsolódik, a lényegi változások ugyanakkor az egész (gazdasági - társadalmi - kulturális) struktúrára érvényesek. Az információs társadalom elméletének egyik alaptézise a megváltozó kommunikációs és médiafogyasztási szokások $^{3}$. Az integrált médiakörnyezet, az újfajta kommunikációs formák olyan

\footnotetext{
${ }^{1}$ A szakirodalomban közel félszáz nevesebb definíció található az információs társadalomról, Z. Karvalics (2007a) ezek közül választott ki néhány olyat, amelyik megőrizte erejét a mai napig is. Az összegyüjtött definíciók egészen eltérő aspektusokat emelnek ki így az innovációt, a tudást (pl.: Bell, Naisbitt) az információs javak termelését (pl.: Masuda, Nick Moore). Murányi Béla definíciója szerint olyan új típusú társadalomról beszélünk, „melyben az információs és telekommunikációs technológiák globális elterjedésének segítségével az emberiségnek új típusú életvitelre, magasabb minőségú életre, munkavégzésre, társadalomban betöltött szerepre van lehetősége."

2 Urbán (2006) hivatkozik Toffler 1980-as művére, ahol Toffler a mezőgazdasági, majd ipari forradalmat követő ún. harmadik hullám várható jellemzőit vizsgálja, már említve az információs társadalom, elektronikus világ, globális falu fogalmakat. Wirtz (1999) az ipari forradalommal kezdődő időtávot vizsgálva megállapítja, hogy az információs társadalom megszilárdulása beleillik a Kondratyev-ciklusba. „A gőzgép megszületése (1800 körül), a vasút és acélipar fejlődése (1850 körül), az elektromosság és a vegyipar megjelenése (1900 körül) és a molekuláris biológia, illetve az autóipar térhódítása (1950 körül) egyaránt az ipari társadalom fontos fejlődési fokait jelentették. Az ipariból az információs társadalomba lépve a Kondratyev-ciklus valamelyest felgyorsult ugyan, de az információs technológia és az internet robbanásszerű terjedése (1990-es évek) beleillik a gazdasági élet ciklikusságának eddigi folyamatába." (Urbán, 2006)

${ }^{3} \mathrm{Az}$ információs társadalom mérhetőségének két fontos próbaköve (1) az inter-konnektivitás, amely a kölcsönös összekapcsoltság mértékében telefonhálózatnál 50 százalék feletti és (2) a fogyasztás, amely a vásárolt információs és kulturális javak, eszközök és szolgáltatások tekintetében egyharmados (a fogyasztói kosár szerinti) lélektani határt határoz meg. (Z. Karvalics, 2007a)
} 
fogalmakat hoznak a köztudatba, mint a közösségi média, vagy az egyidejü többcsatornás kommunikáció és médiafogyasztás.

Az egyidejű többcsatornás kommunikáció és médiafogyasztás elnevezés összefoglalóan próbálja megragadni a média multitasking (Baron, 2005; Ahlers, 2006; Kenyon és Lions, 2007; Greenfield, 2009; Ophir, 2009; Roberts és Foehr, 2009, Salvucci és mtsai, 2009; Bannister és Remenyi, 2009; Wallis, 2010) és az infokommunikációs eszközökhöz kötődő multikommunikáció (Turner - Reinsch, 2007; Stephens, et al., 2008) fogalmát.

A továbbiakban multitasking ${ }^{4}$ alatt két vagy több tevékenység adott idő alatt történő párhuzamos lefolyását értem. Az egyidejű többcsatornás kommunikáció és médiafogyasztás, vagy másként média és kommunikációs multitasking fogalmát azokra a szimultán folyamatokra használom, amikor egy adott kontextusban legalább egy5 média és kommunikációs tevékenység jelen van.

Habár kutatásomban elsősorban az fiatal generációk (ifjúság) kommunikációs és médiafogyasztási szokásaira koncentrálok, azonban a téma megköveteli, hogy az idősebbek korosztályával összehasonlítva határozzuk meg annak jellegzetességeit. Az ifjúság meghatározását jelen szűk keretek között is fontosnak tartom. Az ifjúságról szólva kézenfekvő életkori csoportokkal dolgozni, a szakirodalmakban azonban többféle meghatározásról, lehatárolásról olvashatunk. (Nagy, 2008) Ezek általában kétféle, adminisztratív és fejlődési szempontból közelítik meg az ifjúság fogalmát. Előbbit elsősorban a jogtudomány, utóbbit a biológiai és a társadalomtudományok használják. A pszichológiai és szociológiai megközelítések bár közös tőről fakadnak a legkülönbözőbb meghatározással, felosztással élnek. Az Ifjúságügy című könyv szerint az ifjúság a gyermekek és a fiatalok (valamint a posztadoleszcens) korosztályai együttesen. A különböző értelmezések alapján kijelenthető, hogy a gyermek és a fiatal nem két diszjunkt halmazt, hanem egymást átfedő viszonyok együttese. (Nagy, 2008) A társadalomtudományos definíció többdimenziós (élethelyzetre és nem elsősorban

\footnotetext{
${ }^{4}$ Megtalálható még: szimultán, átfedő, egyidejű, parallel, másodlagos tevékenységek, többfeladatos feldolgozás. Munkámban ezeket a különböző jelzőket egymásnak megfeleltetve, ugyanarra a jelenségre használom.

${ }^{5}$ Szigorúbb definíció lehetne, ha legalább két ilyen jellegű tevékenység esetén beszélhetnénk csak média és kommunikációs multitaskingról, hiszen ez fogalmilag megalapozottabb, a jelenséget pontosabban leíró meghatározás. Illetve beszélhetnénk média, vagy kommunikációs jellegű multitaskingról, amennyiben csupán egy ilyen tevékenység van jelen más jellegű (nem média vagy kommunikációs) tevékenységek mellett, továbbá beszélhetnénk tisztán média és kommunikációs multitaskingról, amennyiben kizárólag ilyen tevékenységek vannak jelen a kontextusban. Habár ez a terminológia logikailag tisztább konstrukció, a megértést segítő lényegi funkciója nincs, ezért munkámban nélkülözöm a használatát.
} 
életkorra korlátozódó) igénye abból fakad, hogy a köznapi gondolkodás is részletgazdag és szituációfüggő meghatározással dolgozik abban, hogy kit tekintünk fiatalnak, gyermeknek, serdülőnek, fiatal felnőttnek, stb. Kutatásomban az alábbi életkorhoz kötődő ifjúsági csoportokra kívánok kiemelt figyelmet fordítani: a gyerekekre (kb. 8-12 éves kortól - kb. 14 éves korig), a serdülőkorúakra (kb. 14 éves kortól - kb. 18 éves korig), valamint a fiatal felnőttek korosztályára (kb. 19 éves kortól - kb. 25/30 éves korig).

A vizsgálni kívánt ifjúsági csoportok értelmezéséhez szorosan kapcsolódnak az információs társadalom szocializációs szerepe szempontjából értelmezett $\mathrm{Y}$ és $\mathrm{Z}$ generációk. Munkám szempontjából a generációs értelmezés azért fontos, mert az Y generációként azonosított fiatal korcsoportban figyelik meg elsőként a korcsoportra általánosan jellemző média és kommunikációs multitaskingot, ami a Z generáció tagjai között teljesedik ki és válik az egyik legfontosabb karakteres elemmé. A szakirodalomban az egyes generációk meghatározása alapvetően születési év alapján történik, azonban többféle egymással konkuráló - más születési kohorszokat érintő definíció is használatos. Dolgozatomban megkísérlem az empirikus adatok alapján megvizsgálni az életkori és a generációs hatások erősségét a párhuzamos médiafogyasztás és általában a médiafogyasztás mennyiségének alakulása tekintetében. 


\section{ELMÉLETI MEGKÖZELÍTÉSEK}

\subsection{AZ EGYIDEJÜ TÖBBCSATORNÁS KOMMUNIKÁCIÓ ÉS MÉDIAFOGYASZTÁS FOGALMA}

A multitasking a számítástechnikában az alapvető fogalmak közé tartozik. Multitasking alatt több feladat, vagy folyamat egyidejű, egy központi feldolgozó egység (processzor) általi kezelését értjük, a párhuzamosság képessége a felhasználó számára úgy jelenik meg, hogy egyidejűleg tud több programot futtatni (pl. nyomtatás közben internetezni; letöltés közben dokumentumot szerkeszteni, stb.).

Míg a computer multitasking lehetősége a processzorok megnövekedett kapacitásának köszönhető, az ebből alkotott humán multitasking az idő fogalmának átalakulásához köthető 6 . Az információs társadalom korában az idő (és a tér) nem igazodási keretként adott, hanem változtatható paramétereként van jelen. Az idő fogalmának megváltozása a gazdasági, társadalmi és kulturális alrendszerben egyaránt érzékelhető. Robinson és Godbey (1997) a multitasking fogalmát úgy közelítették meg, mint az idő mélyítése (deepening of time), Kenyon (2008) az idő kiszélesítéséről (broadening of time) beszél.

Az idő átalakuló szerepére az információs társadalom alrendszereiben számtalan példát találunk. Az információs társadalom gazdasági rendszerének - amit Szabó és Hámori információgazdaságnak, Castells hálózati gazdaságnak nevez - egyik jellegzetessége, hogy általánossá válik az időalapú verseny, felértékelődik a gyorsaság, a vállalatok egyre nagyobb választékot, egyre változatosabb, személyre szabottabb terméket dobnak piacra. Lerövidült a termékek kifejlesztése, előállítása és forgalmazása között eltelt idő, a profitot jelentősen befolyásolja, hogy a termékek milyen gyorsan kerülnek piacra, valamint az is, hogy a vállalatok milyen sűrűn frissítik termékpalettájukat?7.

\footnotetext{
${ }^{6}$ Futó és Rab (2007) a Budapesti Corvinus Egyetemen tartott „Információs Társadalom” c. kurzushoz kapcsolódó fogalomtárjukban a következőképp határozzák meg a multitaskingot: „Többfeladatos feldolgozás. Eredetileg csak számítógépeknél, mára az élet egyéb területein is használt kifejezés, mely a felhasználó által egy időben végzett több cselekvést jelenti." Barabási világhírű könyvében beszél a multitaskingról, ami „olyan gyakorlat, amelyet a saját alkotásunktól, a számítógéptől kölcsönöztünk”. (Barabási, 2008)

${ }^{7}$ Erre számos példát lehetne hozni, míg korábban egy-egy autótípust évtizedekig gyártottak, pl.: a legendás „bogárhátú” Volkswagent hatvan évig gyártották, a Volkswagen Passat első három szériája közel tíz évig (1973-1981, majd 1980-1989 és 1988-1997) futott le a gyártószalagról, addig az azt követő modellek fele ennyi idő alatt váltották egymást (1996-2000 és 2000-2005). Az elvárt gyorsaságra másik
} 
A posztindusztriális társadalom a tercier szektor felemelkedésének korszaka. (Bell, 1973) A gyorsaság mellett a szolgáltatásközpontú szemlélet is nagyfokú rugalmasságot követel meg a vállalatok részéről, amelyhez kapcsolódóan erősödött meg az 1990-es évek második felétől a napi 24-órás, heti 7 napos szolgáltatási kultúra elsősorban az Egyesült Államokban. A szolgáltatásközpontú gondolkodás a korábbi kereteket átalakítva (idő)zsonglőrködésre készteti a menedzsereket, hogy rugalmasan megfeleljenek az ügyféligényeknek.

Castells (2005) szerint a hálózati társadalomban mind a biológiai, mind a társadalmi életciklus ritmusa megbomlik (pl. kitolódó gyermekvállalás, hosszú időskor). A valóságos virtualitás átalakítja az idő kezelését egyidejűség és időtlenség dimenzióiba transzformálva azt, kialakul az örökkévalóság és az ideiglenesség kultúrája. Az idő kezelése folyamatos stresszt jelent az információs társadalom embere számára, aki egyre harcol a korosodással és az életpályán való előrehaladással. Az idő szorítása leginkább a mindennapokban mutatkozik meg, ahol a feladatok és igények által hajszoltan olyan stratégiákra kényszerülünk, amelyeket az idő kibővíthetőségének illúziója táplál ${ }^{8}$. Kenyon (2008) Kitterod (2001) és Ruuskanene (2004) munkái alapján megállapítja, hogy a párhuzamosság leggyakoribb oka a szükséglet és az időhiány (time pressure), ritkák azonban a multitasking mélyebb okait firtató kvalitatív kutatások.

Az idő szorítása azonban nem csupán a kötelezettségeinkkel (feladatok, határidők) kapcsolatban érzékelhető, hanem az alapvetően szabadidős tereket - így a tartalomfogyasztást - is áthatja, bár paradox módon elsősorban nem a növekvő elvárások, hanem a lehetőségek miatt. Gálik (2003) megemlíti, hogy miközben folyamatosan növekszik az egyén számára elérhető médiatartalmak mennyisége a fogyasztásnak gátat szabhat az időkorlát (egy nap továbbra is 24 órából áll), amelynek következtében a médiafogyasztás során szerepet kap a szelektív figyelem és a részleges odafigyelés. Míg előbbi a fogyasztó számára lényeges tartalmat választja el a lényegtelentől, utóbbi az odafigyelés intenzitását csökkenti, azaz az üzenetek eljutnak

példa, hogy az egy percen belüli hitelbírálat már Magyarországon sem lehetetlen dolog, ugyanez a procedúra Japánban mindössze 10 másodperc.

${ }^{8} \mathrm{Az}$ időhiány jelenségével többen is foglalkoztak, Moshe (2012) gyűjtése alapján a következőkről beszélhetünk: krónikus időhiány (chronic time pressure) (Szollos, 2009), idő válság (time crunch) (Zuzanek, 2004), idő deficit (time deficit) (Bianchi et al., 2005), idő éhség (time famine) (Robinson és Godbey, 1999), idő szegénység (time poverty) (De Graaf, 2003), idő szűkösség (time scarcity) (Hirsch, 1976), idő betegség (time sickness) (Dossey, 1982), idő stressz (time stress) (Csikszentmihalyi, 1997), időprés (time squeeze) (Jacobs és Gerson, 2004). 
ugyan, de a befogadó nem mélyed el bennük. Az idő paraméterezését alapértelmezésként tartalmazó online megoldások a hagyományos média területén is helyet követelnek maguknak és olyan médiafogyasztási szokásokat szolgálnak ki, mint a televíziózás területén megjelenő késleltetett nézést (time-shifting). (Nyirő - Urbán, 2007)

Az időmérleg-vizsgálatok korábban nem foglalkoztak a párhuzamos tevékenységekkel, bár elég korán felismerték a jelenség fontosságát ${ }^{9}$, de csak az utóbbi évtizedben kezdték igazán rögzíteni és elemezni ilyen adatokat. (Kenyon, 2008) Habár az egyidejű tevékenységek gyakorisága a hétköznapi életben könnyedén megfigyelhető, az időmérleg-vizsgálatokban alig jelent meg a nehezen kezelhetősége miatt. Az idő lineáris szemléletét számosan megkérdőjelezik, mondván a valóságtól teljesen idegen az, hogy egy-egy tevékenységet csak bizonyos időpillanatig végzünk világos határral elválasztva egy másik tevékenységtől. (Adams, 1995; Gershuny and Sullivan, 1998) Azokban az időmérleg-vizsgálatokban, ahol vizsgálták a párhuzamosan végzett tevékenységek jelenségét, azt találták, hogy a népesség túlnyomó többsége beszámol ilyen tapasztalatokról. Kenyon (2008) korábbi kutatásokra hivatkozva (Hungerford, 2001; Bittman - Wajcman, 2000; Floro - Miles, 2001; Ruuskanene, 2004) azt állítja, hogy az emberek 95 százalékára jellemző a multitasking tevékenység és mindennapjaik mintegy egyharmadában végeznek párhuzamos tevékenységeket. (Kenyon, 2008)

A multitasking tehát mindennapos tevékenység, az emberek túlnyomó többsége naponta gyakorolja úgy, hogy valójában nincs is ennek tudatában. Spink és munkatársai idézik MacIntyre (2001) megállapítását, miszerint a multitasking egy lényeges emberi viselkedés, mind otthoni mind munkahelyi környezetben. Több, konkurens tevékenységet foglal magában, amit egyre inkább elősegítenek az információs rendszerek. (Spink et al., 2007)

Gyakran adódnak olyan helyzetek, amikor megosztjuk figyelmünket és gyakoriak az olyan tevékenységek, amelyek természetüknél fogva megkövetelik a

\footnotetext{
${ }^{9}$ Kenyon (2008) Szalai 1972-es munkájára hivatkozik példaként (Szalai, A. (1972): The Use of Time: Daily Activities of Urban and Suburban Populations in Twelve Countries. The Hague: Mouton). A szimultán folyamatként, egymást átfedő tevékenységként, konkurens feladatokként, párhuzamos aktivitásokként, másodlagos tevékenységekként, polikrónikus időhasználatként, vagy éppen multitaskingként azonosított jelenség régóta ismert és fontos kérdése az időmérleg-vizsgálatoknak.

Stephens és munkatársai felhívják a figyelmet több kapcsolódó fogalomra, így a több infokommunikációs technológia (IKT) egyidejű, vagy szimultán használatára (Monge - Kalman, 1996), rekombináns használatra (Lievrouw - Livingstone, 2002), az oktatási környezetben való médiakeveredésre (Rice, et al., 2004). (Stephens, et al., 2008)
} 
figyelemmegosztást. A multitasking vonatkozhat kognitív és fizikai akciók kombinációira, két vagy több feladatra konkurens, illetve szekvenciális módon, beleértve a váltást a feladatok között. (Spink et al., 2007) Vannak kifejezetten olyan cselekvések, amelyek a másodlagos tevékenységek közé sorolódnak, ilyen például a gyermeknevelés ${ }^{10}$ (Ironmongert hivatkozza Kenyon, 2008), amely a ráfordított idő háromnegyedében csupán másodlagos tevékenység, de ilyen a házimunka (Sullivan, 1997; Bittman - Wajcman, 2000), a szabadidő passzív eltöltése így a médiafogyasztás vagy a kommunikációs tevékenységek (Ironmonger, 2003; Baron, 2005). Egyes kutatók a szimultán tevékenységek felértékelődését az utazással kötik össze, állításuk szerint az utazással töltött idő kihasználatlan idő, így különösen praktikus összekötni más tevékenységekkel, szórakozással, kapcsolattartással, vagy munkával. Újabban a közlekedéssel kapcsolatos tanulmányok is elkezdtek foglalkozni a multitasking jelenségével, Kenyon (2008) idézi Laurier (2004), Lyons és Urry (2005) illetve Kenyon és Lyons (2007) munkáit. Az idézett munkák kiemelik az utazás során zajló multitasking előnyeit, miáltal kommunikálni, szórakozni és a fizetett munkát végezni is lehet az út során. (Kenyon, 2008) Az utazás szerepéhez kapcsolódóan Schroeder (2010) Haddon (2004) nyomán megjegyzi, hogy a mobiltelefon használat gyakran holt időben történik, például utazás közben. ${ }^{11} \mathrm{~A}$ holt időben történő eszközhasználat az okostelefonok elterjedésével vált igazán népszerűvé, ennek vélhetően az az oka, hogy az okostelefonok funkcionalitása és élménykínálata sokkal bővebb, mint a hagyományos mobiltelefonoké. Az okostelefonok holt időben történő használata (instant játék, böngészés, közösségi oldalak, e-mail ellenőrzés stb.) egészen köznapi jelenség, amelyet csipegető kultúrának (snacking culture) is neveznek. A tapasztalatok szerint a holt időben történő használat mellett egyre gyakoribb, hogy más tevékenységek alatt is megjelennek ezek a csipegetések (pl. a vasárnapi ebéd alatt, barátokkal, munkatársakkal folytatott

\footnotetext{
${ }^{10}$ A gyermekneveléshez és az otthoni teendőkhöz kapcsolódó multitasking tevékenységet Bianchi (2011) a családok kényszerű stresszes stratégiájának látja, amivel a szülők megpróbálják az idejüket menedzselni, azonban a feszített időbeosztások következményeként később vállalnak gyermeket, ami végső soron a társadalom elöregedéséhez vezet.

${ }^{11}$ Schroeder (2010) összehasonlítja Svédország, az Egyesült Államok, Japán és Korea a mobiltelefonhoz és számítógéphez kötődő internethasználatát. A távol-keleti országokban a mobil-internet használati aránya magasnak mondható, míg a számítógépes szörfölés kisebb mértékű, míg Svédországban és az USA-ban ennek a fordítottja tapasztalható. Magyarázatként felvethető, hogy a japánok és a koreaiak jellemzően hosszú időt töltenek a tömegközlekedéssel, ami közben mobiltelefonjukkal elvégezhetik internetes tennivalóikat, sőt a mobilokon történő könyvolvasás is értelmet kap a hosszú tömegközlekedéssel töltött idő miatt. Ez arra enged következtetni, hogy ugyanaz az eszköz egymással versengő funkciókra (emailezés, telefonálás, videonézés, stb.) is használható, de ezt a versenyt korlátozza a felhasználó figyelme.
} 
beszélgetések alkalmával, médiafogyasztás közben, stb.), amely ilyen módon már átfedő tevékenységekként értelmezhető ${ }^{12}$.

A kutatók egyetérteni látszanak abban, hogy a párhuzamosság egyfajta válasz az időprésre, egyre több feladatot kellene elvégezni egyre rövidebb idő alatt. Az egyén oldaláról a multitasking azt jelenti, hogy megkísérel egy időintervallumba belesűríteni két vagy több együttesen az adott időintervallumot meghaladó időmennyiséget igénylő tevékenységet. Kenyon (2008) számításai szerint a párhuzamosság átlagosan 7 órát ad hozzá egy naphoz, ami egybevág Ironmonger 7,5 órás eredményével.

Az idő, mint rugalmasan változtatható paraméter soha korábban nem volt ennyire fontos. Az időalapú verseny és az annak eredményeképpen megjelenő termék- és szolgáltatásbőség olyan időspirálba szorítja az információs társadalom emberét, ahol egyik felől erőforrás-bővítő tevékenységei (pl. határidős munkák, vizsgák, stb.) késztetik rugalmasságra, másik felől a szabadidős lehetőségeinek megnövekedett kínálata ösztönzi idejének hatékonyabb menedzselésére. A felborult időt már nem pusztán az éjszakai műszakokban, vagy a folyamatosan „nyitva tartó” internetben, hanem az összecsúszó alaptevékenységekben (pl. élethosszig tartó tanulás) és életszakaszokban (pl. a fiatalkor különböző formáinak kialakulása) is tetten érhetjük. Az idő szorításában tehát a párhuzamosság olyan eszköz, vagy készség, ami az apró feladatoktól (pl. tévézés közbeni online csevegés) az életet alapvetően meghatározó tevékenységekig (pl. munka és tanulás összehangolása) lehetővé teszi, hogy alkalmazkodjunk a körülményekhez, hiszen az alkalmazkodóképesség az egyik legfontosabb emberi tulajdonság.

\footnotetext{
12 Turkle (2011) azt állítja, hogy sokszor előfordul, hogy a társas tevékenységeink során is inkább az eszközeinkhez fordulunk, hiszen lehetőség van arra, hogy ha a kontextust holt időként érzékeljük, valami sokkal fontosabbat csináljunk. Ez a gyakorlat állítása szerint egyfajta társas magánnyá vezethet.
} 


\subsection{MULTITASKING NARRATÍVÁK}

Barabási (2008) világhírű könyvében a multitaskingról szólva kiemeli, hogy az effajta készség, azaz annak képessége, hogy több dolgot hatékonyan képes az ember egyszerre végezni „őseinktől örökölt” tulajdonság, amire az élő és élettelen komplex rendszerek legtöbbje képes. A rendszerek párhuzamos feldolgozási képessége a modularitásnak, az önálló részekből való felépülésnek köszönhető, amely a legtöbb komplex rendszernek meghatározója. Barabási könyve a hálózatok szerepéről számos tudóst és tudományágat megihletett már a biológiától a vezetéstudományig. A skálafüggetlen hálózatokat (pl. az internet ilyen) kutatva megfigyelte, hogy az úgynevezett hierarchikus modularitás a párhuzamosság szervezőelve, amely a különböző feladatok, különböző szinteken való önálló elvégzését jelenti. A hierarchikus modularitást egy nagyvállalat példáján bemutatva azt jelenti, hogy a különböző vállalat-részek a maguk feladatát hatékonyan tudják végezni, míg a felső szinteken az egész vállalat menedzselése, az egyes részek összekötése történik. Barabási munkája rávilágít arra, hogy az egymást átfedő tevékenységek korlátai is a modularitásban rejlenek, azaz ha egy-egy modul túl sok feladatot kap a rendszer lelassul. Míg a hatékonyság a számítógépek esetén a központi egység, azaz a processzor számítási teljesítményének, addig az emberi szervezet esetén a kognitív rendszer függvénye.

A rendelkezésre álló kutatási eredmények szerint a párhuzamos tevékenységeket (kiemelten a média multitaskingot) többféle keretben és kontextusban lehet értelmezni. A következőkben a legfontosabb narratívákat veszem sorra (amelyek több helyen össze is kapcsolódnak), kívülről befelé haladva: elsőként az információs társadalom rendszerszintű hatásaival foglalkozom, amelyek megteremtik azokat az újfajta lehetőségeket, amelyek a média és kommunikációs multitasking hajtóerejét jelenthetik. Ezt követően a média és kommunikációs multitasking szocializációs és környezeti kapcsolódásaival foglalkozom, amelyek egy-egy generáció karakterét is meghatározhatják, továbbá a multitasking szociodemográfiai magyarázóit mutatom be. Fontosnak tartom megemlíteni azokat a kognitív szempontokat is, amelyekre a jelenségre elsőként reflektáló pszichológiai kutatások hívják fel a figyelmet. A különböző megközelítések bemutatását a szimultán folyamatokba belépő tevékenység céljainak és jellegének elemzésével zárom. 
A média és kommunikációs multitasking az információs társadalom által biztosított környezetben tud igazán kiteljesedni ${ }^{13}$. Az információs társadalom hatásai ugyan globálisan érvényesülnek, azonban a bevonódás (vagy felzárkózás) a nagyobb paradigmaváltásokhoz hasonlóan lassabban megy végbe, így az olyan fogyasztási jellegzetességek, mint a párhuzamos médiafogyasztás különbözőképpen vannak jelen az egyes társadalmi csoportokban. Számos kutatás megerősítette azt a felismerést, hogy a digitális egyenlőtlenség a hagyományos egyenlőtlenségek mentén termelődik, és tovább növeli ezeket. $\mathrm{Az}$ is nyilvánvaló, hogy az ún. digitális szakadék és a társadalmi egyenlőtlenség hagyományos dimenziói kölcsönösen hatnak egymásra ${ }^{14}$ és magyarázzák egymást ${ }^{15}$.

\footnotetext{
${ }^{13}$ Maga a média multitasking fogalma is kapcsolódik a számítógépes szaknyelv multitasking fogalmához, ami arra utal, hogy a számítógépek egyszerre több alkalmazást tudnak futtatni a video-streamingtől kezdve a szokványos alkalmazásokig. (Vandewater - Lee, 2009)

${ }^{14}$ Ebből adódóan az infokommunikációs eszközökhöz kapcsolódó tudás, elsősorban a számítógép, illetve az internet használatához szükséges ismeretek megléte közvetlenül is hatással lehet az egyén társadalmi helyzetének megváltozására.

Az IKT eszközökhöz kapcsolódó tudás, ha előnyhöz nem is juttat, hiánya mindenképpen hátrányként jelentkezik más dimenziókban, például a munkaerőpiacon. Ezen kívül létezhet közvetett hatás is: ez az elmélet arra a gondolatra épít, hogy az infokommunikációs eszközök alkalmazási készségei és az alkalmazásban való jártasság a kulturális tőke részét képezi. Az IKT eszközök alkalmazásával egyúttal növekszik a kommunikációs potenciál, ami a társadalmi tőke növekedéséhez vezet. Mivel bizonyított tény, hogy a kulturális tőke hatással van az egyén státusára, az IKT használati szintjének változásával az egyén erőforrásainak mennyisége is megváltozik, ami egyszersmind a társadalmi mobilitásra való esély mértékének megváltozását is jelenti. Szintén bizonyítottnak tekinthető, hogy a társadalmi tőke erősíti a mobilitást is, a gyenge kötések ugyanis nagyban segítik a felfelé irányuló mobilitást. (Rigler, 2005)

${ }^{15}$ A digitális szakadék leírásakor legalább két jelenséget kell megkülönböztetni. Egyrészt a hozzáférés és az ellátottság eltéréseiről beszélhetünk, aminek gyakran területi (vidéki területek gyengébb infrastrukturális ellátottsága) vagy anyagi okai vannak. Másrészt azonban azonosítani lehet a használat módjában tapasztalható különbségeket: azok, akik hozzáférnek a világhálóhoz, messze nem ugyanúgy használják, sőt, a használat képességében is óriási különbségek vannak.

Goldfarb és Prince (2008) kimutatta, hogy a jövedelem és az iskolázottság függvényében eltérően alakulnak a hozzáférési és használati jellemzők. A magasabb jövedelmű és a magasabb iskolai végzettségű csoportokban magasabb a hozzáférés aránya is, a használattal töltött idő azonban negatívan korrelál. A kutatás ezt azzal magyarázza, hogy az alacsonyabb jövedelműek és végzettségúek szabadidejének alternatív költsége (opportunity cost) alacsonyabb, vagyis inkább megengedhetik maguknak, hogy sok időt töltsenek a számítógép előtt ülve.

Az internettől való távolmaradás okait számos külföldi és hazai kutatás vizsgálta. A kérdés bonyolultságát az adja, hogy társadalmi és egyéni szintű változók egyaránt befolyásolják, hogy kiből lesz felhasználó és ki az, aki teljesen elzárkózik a technológiától. A társadalmi-gazdasági jellemzők mellett az egyéni, pszichológia jellegú változók szerepére is érdemes odafigyelni, ami részben a belső ösztönzők, részben pedig a félelmek, gátak összességéből áll össze. Egy, a flamand kamaszok körében végzett kutatás szerint a szociodemográfiai jellemzők mellett a pszichológiai faktoroknak van kiemelkedő jelentőségük a számítógép- és internet használat szempontjából. Meglepő módon, ebből a kutatásból az derült ki, hogy a fiúk és a lányok használata között jelentős különbségek vannak, holott általában az a vélemény, hogy a nemnek inkább csak később, felnőtt korban van szerepe. (Broos-Roe, 2007)
} 
Az empirikus kutatások szerint az információs társadalom szempontjaiból hátrányos helyzetű csoportok más (gazdasági, kulturális, társadalmi) szempontokból is rendre hátrányos helyzetűnek bizonyulnak. Mindez azonban nem jelenti azt, hogy ne lennének kritikái az információs társadalom evangélistáinak, a technooptimista megközelítéseknek. Goldhaber (2004) például a homo interneticusról azaz az internethasználó emberről beszél, amellyel az olvasás képessége utáni fázist írja le. Goldhaber érvelése szerint a korábbiak (szóbeli kommunikáció, írásbeli kommunikáció) nem vesznek ugyan el, azonban gyökeresen átalakulnak felületesebbé válnak az új paradigma érvényesülésével. Sherry Turkle (2011) szerint túlságosan „belehabarodtunk” a technológiába, átadtuk a vezérlést az eszközeinknek, ami elmagányosodáshoz vezet. A technológia új vívmányai képessé tesznek jobban irányítani a figyelmünket a minket érdeklő dolgokra, az állandó bekapcsoltság a társaság érzetét kelti, a világét, ahol sohasem vagyunk egyedül, ahol meghallgatnak minket. Ez azonban csupán illúzió, vallja Turkle, aki szerint a tudatosság hiánya egyfajta társas magányhoz ${ }^{16}$ vezet.

A digitális megosztottság kezdeti (mennyiségi) indikátorai mellett ma már egyre többet beszélnek a minőségi különbségekről. Galácz-Ságvári (2008) arra hívták fel a figyelmet, hogy a hozzáférés növekedésével már nem az a fontos, hogy ki fér hozzá az internethez

Beckers és társai (2008) az ún. számítógép szorongást (computer anxiety) vizsgálták. Számítógép szorongásnak definiálják azt, ha valaki félelmet vagy nyugtalanságot érez akkor, amikor számítógépet használ. Ilyen jellegű kutatások a korábbiakban is készültek és a számítógép szorongás leírására olyan változókat alkalmaznak, mint például a magabiztosság mértéke a használat elsajátítása során, a számítógép nem-kedvelése, a számítógép elkerülése vagy előzetes idegesség amiatt, mert használni kell.

A számítógéphez kapcsolódó szorongás megjelenése erős kapcsolatban van az életkorral és az iskolai végzettséggel. Az idősebb emberek - a fiatalabbakkal összehasonlítva - másképp működnek, rosszabb a rövidtávú memóriájuk, gyengébbek a vizuális képességeik és fejletlenebbek a mozgással kapcsolatos adottságaik (pl. gépelés). Mindezek hozzájárulnak az csekélyebb arányú számítógép-használathoz. Beckers és társai elemzése azonban azt a meglepő eredményt hozta, hogy ez a szorongás jelen van fiatal, képzett és tapasztalt felhasználókban is. A tanulmány következtetése szerint a számítógéphez kapcsolódó szorongás egyéni szinten kezelhető és megszüntethető, alapvetően azonban sokakban vannak zsigeri félelmek a technológiával szemben, így társadalmi szinten aligha számolható fel ez a jelenség.

Beckers és Schmidt (2003) kutatása arra hívja fel a figyelmet, hogy a számítógép szorongás nagyban függ attól, hogy az adott felhasználónak milyen élmény volt a számítógéppel való első találkozás: az, hogy ez mennyire volt pozitív, rendelkezésre állt-e hozzáértő és türelmes segítség, hosszú időre meghatározza a technológiához való viszonyt.

Az idősebbek internet használati szokásait Morris és szerzőtársai (2007) mélyinterjúk és fókuszcsoportok segítségével vizsgálta. A kutatás fontos eredménye, hogy az idősebb korosztályon belül is jelentős különbségek vannak, nem lehet homogén csoportként kezelni még az egyazon korosztályba tartozókat sem. Általánosságként azonban elmondható, hogy az idősebbeket elsősorban a levelezés és az információszerzés vonzza az internetben. Hasonló következtetésre jut Nagy Réka is a fiatalokra koncentráló munkájában, meglátása szerint hasonlóan markáns különbségek jellemzik a fiatalok technológiahasználatát, mint az idősebbekét. (Nagy, 2007)

16 Turkle téziseihez hasonlóan Jackson (2008) is (a kreativitás visszaesése mellett) az elmagányosodást emeli ki a könyvében, mint káros hatását a figyelem technológiaorientáltságának. 
és ki nem, hanem hogy ki mit csinál és mit képes csinálni, amikor használja a világhálót, azaz a használat minősége válik a megkülönböztetés dimenziójává. Még ha elméletileg meg is valósulhat a 100 százalékos penetráció, ez nem jelenti a digitális megosztottság megszűnését, hanem inkább a felhasználók között fennálló különbségek válnak egyre fontosabbá.

De nem csak a készségek hiánya, hanem az igények és a szokások is árnyalják a képet. A felhasználók jó része ritkán és keveset használja az internetet, használata beszűkül néhány oldal látogatására, míg mások szinte online élik az életüket - munkájuk, szórakozásuk, és másokkal való kommunikációjuk nagy részét a világhálón élik meg. A használók - nem használók dichotómiára építő digitális megosztottság továbbgondolása abba az irányba mutat, hogy a használat puszta tényén kívül figyelembe veszik annak jellemzőit, az információs igényeket, azt, hogy a technológia miként segíti az egyéneket a mindennapi társadalmi életben.

Ahogy a hozzáférés és a használat egyszerű dichotóm kategóriái kezdik elveszíteni erejüket egyre fontosabbá válnak az olyan alternatív fogalmak mint a digitális írástudás, a média írástudás (műveltség), vagy az információs írástudás, amelyek többé-kevésbé a használatbeli különbségeket kívánják megvilágítani.

Az egyes fogalmak különböző forrásokból erednek és különbözőképpen használatosak, azonban definícióikban találhatunk számos egyezőséget. A digitális írástudás, vagy digitális műveltség gyakorta használatos a digitális kompetencia szinonimájaként, azaz utal azokra a készségekre és tudásokra, amelyek az infokommunikációs eszközök kezelésének szintjét hivatottak mérni. A Gilster (1997) által alkotott fogalom azonban az eredeti szándék szerint sokkal többet jelentene ennél, többféle írástudást (műveltséget) is átfog. A leszűkített jelentéshez képest tartalmazza az írás, az olvasás és a számolás készségeit; az értő olvasást és a megszerzett információk kritikus kezelését; a könyvtárak használatának készségét; az információforrások (pl.: tömegkommunikációs források) és az információ kritikus mérlegelésének képességét; továbbá olyan beállítódások és képességek is ide értendők, amelyek a technológia nem pusztán eszközszintű használatát feltételezik. A média írástudás vagy műveltség fogalmának meghatározásakor Koltay (2009), Vargára hivatkozik, eszerint a média műveltség annak képessége, hogy a különböző médiumokból származó információkat értelmezzük, feldolgozzuk, megosszuk, tároljuk, megalkossuk, reflektáljunk azokra. (Koltay, 2009). 
Az információs írástudás sokféle meghatározása használatos. Burchinal (1976), Behrens (1994) és Bawden (2001) nyomán Rab (2008) az információs írástudásra, mint képességek halmazára utal, ahol három szintet határoz meg: „1. azok a képességek, melyek segítenek megtalálni, és használni az információt; 2. az információ használata a problémamegoldásban és a döntéshozásban; 3. hatékony információkeresés és hasznosítás." A fenti fogalom-meghatározásokból jól érzékelhető, hogy mindhárom megközelítés az információ megértését, kezelését (kiválogatását) helyezi középpontba és egyfajta hatékonysági mutatóként funkcionál. A különböző megközelítések közül az információs írástudásnak van olyan általánosító ereje, amely képes magába foglalni mindkét másik fogalmat ${ }^{17}$.

\section{A digitális megosztottság és a párhuzamos fogyasztás összefüggései}

A digitális megosztottság jellegzetességeiből, illetve ehhez kapcsolódóan a készségek és felhasználói tudások különbözőségéből fakadó megközelítések megtalálhatóak a média és kommunikációs multitasking irodalmában is.

A hozzáférés és a használati különbségekre utal Vega (2009) összefoglalója, amely szerint számos az információs társadalmi fejlődésből következő oka van a párhuzamos tevékenységeknek. Az internet által lehetővé válik két, vagy több független tevékenység térbeli és időbeli együttes jelenléte. A virtuális mobilitás hatására, amely meglazítja az idő és a tér tradicionális kötelékeit, olyan tevékenységek is végezhetőek fizikai helyváltoztatás nélkül, amelyek korábban utazás nélkül nem voltak lehetségesek. A számítógép és az internet növeli a multitaskingra alkalmas és az elérhető tevékenységek számát. Roberts és Foehr (2008) szerint a számítógép hiánya csökkeni a multitasking valószínűségét, minden bizonnyal azért, mert a számítógép minden médiumnál jobban támogatja a szimultán feladatmegoldást. Robinson és társai (2002) szerint az internethasználók csoportja többet végez szimultán tevékenységeket, mint akik nem interneteznek. A World Internet Project nemzetközi eredményeire hivatkozva Schroeder

\footnotetext{
${ }^{17} \mathrm{Az}$ információs írástudásnak különböző szintjei vannak, ezek Eisenberg - Berkowitz (1990) és Rab alapján a következők: az információs írástudás első szintjén azonosítjuk a feladatot, meghatározzuk a keresett információt, az eléréshez kapcsolható energia befektetést. A következőkben azonosítjuk az információ lehetséges forrásait majd meghatározzuk a keresés irányát. Az információ megszerzése után (fel kell ismerni a keresett információt) annak megfelelő felhasználása (megértés) és új kombinációk létrehozására (beépítés) is sor kerül. Végül a legmagasabb szinten biztosítjuk a feldolgozott tudás tárolását, visszakereshetőségét és későbbi felhasználását. (Rab, 2008)
} 
(2010) megjegyzi, hogy a legtöbb internetező az online töltött idő során párhuzamos tevékenységeket folytat, zenét hallgat, tévét néz, telefonál. Anderson és Tracey (2002), illetve Nie és társai (2002) arra jutottak, hogy az internethasználat inkább a meglévő tevékenységek mellé épült be, nem pedig azok helyét vette át.

Schroeder (2010) a mobilkommunikációról szóló tanulmányában a multimodális összekapcsoltság ${ }^{18}$ fogalmán keresztül vizsgálja az IKT eszközök használatát és versengését a felhasználói figyelméért' ${ }^{19}$. Megállapítja, hogy a kapcsolatteremtések száma és gyakorisága nem növelhető a végtelenségig, így a kapcsolattartás a csatornák közötti váltásokkal (pl. hang helyett szöveg), több személy felé irányuló kommunikációval (pl. chat szobák, közösségi oldalak), vagy multitasking révén valósítható meg.

Nguyen (2010) az online hírfogyasztás terjedésének okairól készült tanulmányában megállapítja, hogy az egyszerű és a kényelmes hozzáférés mellett legfontosabb tényezők között szerepelnek az internetes hírek különleges tulajdonságai is, elsősorban az állandó elérhetőség és a hírböngészés kombinálhatósága más online tevékenységekkel. Az internetezők miközben barátaikkal lépnek interakcióba, vagy nem hír-értékű információkat keresnek, akár véletlenszerűen is belefuthatnak hírekbe, amelyeket alkalomadtán meg is néznek, el is olvasnak. Nguyen egy Nielsen/NetRatings kutatást idéz, miszerint 2005-ben az internetet többen választották a hagyományos médiánál köszönhetően két kényelmi tulajdonságának: az állandó elérhetőségnek (a felhasználók 83\%-a jelölte meg) és a párhuzamosság lehetőségének (70\% preferálta) ${ }^{20}$.

Spink (2004) illetve Spink és társai (2002) a könyvtárlátogatók felhasználói szokásait vizsgálták a könyvtárak információs rendszereivel kapcsolatban. Megfigyelték, hogy az emberek könyvtárazás, vagy elektronikus információ-keresés során gyakran több információkeresési feladat megoldásán dolgoznak, gondolkoznak, a folyamatban lévő keresési feladat közben újabb témákra kezdenek rákeresni (pl. a kertészeti információk keresése mellett egészségügyi témákra is rákeresnek). (Spink et al., 2007)

\footnotetext{
${ }^{18}$ A különféle kommunikációs csatornák együttes használata a mindennapi élet során.

${ }^{19}$ A multimodális összekapcsoltság egyes formái átfedik egymást, még akkor is, ha az egyes csatornák különböző eszközök által érhetőek el - ennek következtében egyfajta figyelem-gazdálkodás alakul ki közöttük. (Schroeder, 2010)

${ }^{20}$ Hasonló eredményeket mutat be egy Salwen és társai (2005) által készített tanulmány, mely szerint az online hírfogyasztásban komoly szerepet kap az érdekes híreknek való kitettség más online tevékenységek végzése közben a kérdezettek kétharmadánál (68\%). Tewksbury és társai megállapították, hogy az online tevékenységek közben az interneten megjelenő hírekkel való véletlen találkozások növelik a tájékozottságot, ami által egyben kiemelkedik az online hírek kényelmes elérhetősége is. (Nguyen, 2010)
} 
A felhasználói tudással kapcsolatban Ahlers (2006) Cole (2004) munkájára támaszkodva megállapítja, hogy a multitasking főleg az internetet már évek óta, magabiztosan használók körében 21 jellemző. Mindezek alapján elmondható tehát, hogy az infokommunikációs technológiák használata jellemzően párhuzamossággal társul, a magasabb felhasználó tudás fokozza az egyidejű tevékenységeket.

\subsubsection{SZOCIALIZÁCIÓS ÉS KÖRNYEZETI HATÁSOK}

A szocializáció, amelynek hatásai rendszerszinten (szocializációs közegek) és egyéni szinten (környezeti hatások) is értelmezhetők alapvetően befolyásolhatják a viselkedést a gondolati struktúráktól kezdve a fogyasztási szokásokig.

A fiatalok médiafogyasztásával, különösen az új médiával kapcsolatban végzett kutatások egyik legfőbb megállapítása, hogy az döntően különbözik az idősebbek, illetve a korábbi fiatal generációk médiafogyasztásától. Dolgozatom egyik fő kérdése, hogy a fiatalok médiafogyasztásában tapasztalható jellegzetességek inkább korspecifikusak, vagy a digitális korszak fiataljai valóban minőségi változás hordozói.

\section{A szocializációs közegek szerepe}

Nagy és Trencsényi (2012) a szocializációs közegekről szóló munkájukban Giddens elméletéből kiindulva amellett érvelnek, hogy a hagyományos kételemű (család és iskola), illetve háromelemű (család-iskola és munka világa) szocializációs közeg modellek ${ }^{22}$ kiegészítésre szorulnak. A szocializációs közegek, vagy ágensek Giddens szerinti felosztásában is megjelennek a két és háromelemű modelleknél hiányzó tömegkommunikációs eszközök. Megítélésük szerint beszélhetünk olyan harmadlagos szocializációs közegről, amely alapvetően a családon és iskolán kívüli szabadidő

\footnotetext{
${ }^{21} \mathrm{~A}$ magabiztos használók csoportjába tartozók 47 százaléka hallgat rádiót, 33 százaléka néz tévét és 44 százaléka telefonál, miközben online van. (Ahlers, 2006)

22 Léteznek többelemű modellek is, pl. Trencsényi (2006) négyelemű modellel dolgozik, ahol a nevelés „tudatos” szervezeti aktorait veszi figyelembe (természet adta közösségek, állami intézmények, piaci szolgáltatók és civil kezdeményezések) nem tagadja azonban a „spontán” szocializációs közegek létét. Különböző felosztásokban kettőtől-hétig nevezhetünk meg szocializációs közegeket, azonban ezek kritériumai - mitől szocializációs közeg a szocializációs közeg - tisztázatlanok.
} 
különböző tereit hordozza magában, illetve egyes jellemzőiben negyedleges közegről is, amely az információs társadalom virtuális tereit tartalmazza.

A szocializációs közegek közösségi szintű értelmezésében fontos kritérium a hatókör, az eltöltött idő és intenzitás, illetve a saját szabályrendszer léte, amelyek együttállása szükséges ahhoz, hogy egy-egy szocializációs közeget önállóan értelmezhessünk ${ }^{23}$. Nagy és Trencsényi (2012) ezen ismérvek mentén mutatják be és igazolják a harmadlagos és a negyedleges amolyan félközeg működését.

A harmadlagos közegként értelmezett szabadidő hatóköre napjaink társadalmában általánosnak mondható, noha az információs társadalmi átmenet sok esetben elmossa az éles határvonalakat az erőforrás-bővítő tevékenységek (tanulás, munka) és a szabadidős (köztük a rekreációs) tevékenységek között. Az idő és intenzitás tekintetében elmondható, hogy elsősorban a számunkra legérdekesebb ifjúsági korcsoportban a legintenzívebb a családon és iskolán túli kortárscsoport szerepe, az eltöltött idő az életkor előrehaladtával folyamatosan növekszik. Nagy és Trencsényi (2012) kilenc, a család és az iskola jellemzőitől különböző ismérvvel támasztják alá a harmadlagos szocializációs közeg önállóságát. Míg a család (1) fő viszonybeli jellemzője szerint adottság az iskola kötelezettség, addig a szabadidős tevékenységek önkéntes alapon szerveződnek, (2) szervezőelvük az önálló rendelkezés, amely (3) változtathatóságot a kapcsolatok szabad kötését és bontását hordozzák magukban és (4) kölcsönösséget ${ }^{24}$ feltételez. A szabadidős közegben a (5) hatalom nem előre meghatározott, a (6) szabályelfogadás önkéntes alapon történik. A közeg kikristályosodott (7) megjelenése nagyjából egy időben történik, az (8) intézményesítettség inkább nem jellemző rá. A szabadidős közeg érvényesülését erősen meghatározza (9) a család és az iskola, amely rendelkezik az időbeosztás felett.

A negyedleges szocializációs közegként értelmezett új médiatér, amely a tömegkommunikáció és az internet világát foglalja össze hasonlóan általánosan jelen

\footnotetext{
${ }^{23}$ A minőségében is új szocializációs felületet színtérnek, (makro)terepnek, közegnek, a csak tartalmában új felületet szocializációs elemnek, csoportnak nevezhetjük. Egy egyszerű példán keresztül bemutatva: a család szocializációs közegként értelmezhető a származási család és a nemző család szocializációs elemnek tekinthető. (Nagy - Trencsényi, 2012)

${ }^{24} \mathrm{~A}$ kölcsönösség a családon és iskolán túli közegekben túlnyomóan jellemző, a legtöbb esetben szimmetriát és tranzitvitást mutat.
} 
van napjaink társadalmában ${ }^{25}$. A fentiekben már bemutatott kritériumrendszer első elemét a hatókört igazoltnak találjuk, a tömegmédia a társadalom majd minden tagját eléri az infokommunikációs eszközök, a virtuális színterek is egyre fontosabb szereplői az életünknek és ennek megfelelően egyre több időt töltünk ezekben a terekben, az eszközök egyre intenzívebb használata jellemző. A negyedleges közeg kettéválasztásával „tömegkommunikáció” és „modern kommunikáció” szabályszerűségeit megkülönböztethetjük a versengő, illetve hálózatszerű szervezőelv, továbbá az egyirányú és többirányú kölcsönösségi viszony alapján. További különbség az intézményesülés és a hatalom definiálhatósága a tömegkommunikációs térben. Mindezek alapján Nagy és Trencsényi (2012) a tömegkommunikációs tereket inkább önálló, míg a modern kommunikációs tereket inkább nem önálló, amolyan „fél szocializációs közegként" értelmezik.

1. táblázat: Hasonlóságok és különbségek a szocializációs közegekben (Forrás: Nagy - Trencsényi, 2012)

\begin{tabular}{|c|c|c|c|c|c|}
\hline Jellegzetesség & Család & Iskola & $\begin{array}{l}\text { Családon és } \\
\text { iskolán túli } \\
\text { (szabadidős) } \\
\text { tevékenységek }\end{array}$ & Tömegkommunikáció & $\begin{array}{c}\text { Modern } \\
\text { kommunikáció }\end{array}$ \\
\hline $\begin{array}{l}\text { Fő viszonybeli } \\
\text { jellemző }\end{array}$ & adottság & kötelezettség & $\begin{array}{l}\text { önkéntesség } \\
\text { (önkéntesen lehet a } \\
\text { terület egyes } \\
\text { elemeit használni) }\end{array}$ & $\begin{array}{c}\text { önkéntesség (önkéntesen } \\
\text { lehet a terület egyes } \\
\text { elemeit használni) }\end{array}$ & $\begin{array}{c}\text { önkéntesség } \\
\text { (önkéntesen lehet a } \\
\text { terület egyes } \\
\text { elemeit használni) }\end{array}$ \\
\hline Szervezőelv & feltétel-nélküliség & feltételhez kötöttség & $\begin{array}{c}\text { szabad } \\
\text { választhatóság } \\
\text { (önálló, szabad } \\
\text { rendelkezés az } \\
\text { idővel) }\end{array}$ & $\begin{array}{l}\text { versengő } \\
\text { egyközpontúság, szabad } \\
\text { választhatóság }\end{array}$ & $\begin{array}{l}\text { hálózatszerűség, } \\
\text { szabad } \\
\text { választhatóság }\end{array}$ \\
\hline Változása & $\begin{array}{l}\text { nem változtatható } \\
\text { sem személyében, } \\
\text { sem intézményében }\end{array}$ & időben változik & $\begin{array}{l}\text { a kapcsolatok } \\
\text { szabadon oldhatók } \\
\text { és köthetők }\end{array}$ & bármikor & bármikor \\
\hline $\begin{array}{l}\text { Kölcsönösségi } \\
\text { viszony }\end{array}$ & nincs kölcsönösség & nincs kölcsönösség & $\begin{array}{c}\text { megvan a } \\
\text { kölcsönösség }\end{array}$ & $\begin{array}{l}\text { egyirányú, a kölcsönösség } \\
\text { (kevés kivétellel) nem } \\
\text { jellemző }\end{array}$ & $\begin{array}{l}\text { kétirányú jellemző } \\
\text { a kölcsönösség }\end{array}$ \\
\hline Hatalom léte & $\begin{array}{l}\text { létezik a közegben } \\
\text { előre meghatározott } \\
\text { hatalom, mint } \\
\text { természetes } \\
\text { hierarchia (szülők), } \\
\text { aszimmetrikus } \\
\text { hatalom }\end{array}$ & $\begin{array}{l}\text { létezik a közegben előre } \\
\text { meghatározott hatalom, } \\
\text { mint mesterséges } \\
\text { hierarchia (tanárok), } \\
\text { aszimmetrikus hatalom }\end{array}$ & $\begin{array}{l}\text { nem létezik a } \\
\text { közegben előre } \\
\text { meghatározott } \\
\text { hatalom, nincs } \\
\text { előre definiált } \\
\text { hierarchia, } \\
\text { szimmetrikus } \\
\text { hatalom }\end{array}$ & $\begin{array}{c}\text { létezik előre } \\
\text { meghatározott hatalom, } \\
\text { mint mesterséges } \\
\text { hierarchia } \\
\text { (médiamunkások), } \\
\text { aszimmetrikus hatalom }\end{array}$ & $\begin{array}{c}\text { nincs, legfeljebb } \\
\text { piacszerű hatalmi } \\
\text { viszony, a belépés } \\
\text { alacsonyküszöbű, } \\
\text { félaszimmetrikus } \\
\text { hatalom }\end{array}$ \\
\hline Szabályelfogadás & $\begin{array}{l}\text { a fegyelemvállalás- } \\
\text { szabályelfogadás } \\
\text { nem önkéntes }\end{array}$ & $\begin{array}{l}\text { a fegyelemvállalás- } \\
\text { szabályelfogadás nem } \\
\text { önkéntes }\end{array}$ & $\begin{array}{c}\text { a fegyelemvállalás, } \\
\text { szabályelfogadás } \\
\text { önkéntes }\end{array}$ & önkéntes & önkéntes \\
\hline Megjelenés & $\begin{array}{c}\text { a születéstől létező } \\
\text { közeg }\end{array}$ & $\begin{array}{l}\text { iskolás(óvodás)kortól } \\
\text { létező közeg }\end{array}$ & $\begin{array}{l}\text { elemei iránt } \\
\text { felébredő igény } \\
\text { nagyjából egy } \\
\text { időben jelenik meg }\end{array}$ & $\begin{array}{c}\text { koragyerekkortól (2-6 év } \\
\text { között) }\end{array}$ & $\begin{array}{l}\text { koragyerekkortól } \\
\text { (3-8 év között) }\end{array}$ \\
\hline Intézményesítettség & inkább intézményes & intézményes & $\begin{array}{l}\text { inkább nem } \\
\text { intézményes }\end{array}$ & intézményes & nem intézményes \\
\hline Kapcsolatrendszer & $\begin{array}{l}\text { erősen determinált a } \\
\text { más szocializációs } \\
\text { közegekkel alakuló } \\
\text { kapcsolatrendszer }\end{array}$ & $\begin{array}{l}\text { erős hatás más } \\
\text { szocializációs közegekre }\end{array}$ & $\begin{array}{l}\text { függő viszony a } \\
\text { többi közegtől }\end{array}$ & $\begin{array}{l}\text { erős hatás más } \\
\text { szocializációs közegekre }\end{array}$ & $\begin{array}{l}\text { erős hatás más } \\
\text { szocializációs } \\
\text { közegekre }\end{array}$ \\
\hline
\end{tabular}

${ }^{25}$ Akár a szabadidő által kitöltött harmadlagos közeg esetében, itt is találhatunk földrajzi és időbeli korlátokat. Világos, hogy a tömegkommunikációs forradalmat megelőzően nem lehet beszélni ilyen közeg jelenlétéről, ahogy egyes zárt, vagy kevésbé fejlett társadalmakra sem érvényesek ezek a megállapítások. 
A szocializációs közegek természete alapvetően különbözhet egymástól, míg az elsődleges családi közeg a maga természetességével az ősidőktől fogva jelen van és a társadalom alapeleme, addig a másodlagos iskola feltételez egy fejlettségi és intézményesültségi fokot (közoktatás), amely jellemzően egybeesik a nemzetállamok kialakulásával. Szervezett oktatás ugyan létezett már az ókori Egyiptomban is, ugyanakkor a társadalom nagy részét átfogó, általános, formális oktatási tevékenység a modern nemzetállamok sajátja ${ }^{26}$.

A harmadlagos és negyedleges szocializációs közegek kikristályosodása27 nyilvánvalóan egybeesik az információs társadalom megszületésével, kiépülése a '60-as évek óta folyamatos. Az ipari társadalom racionalitásának (mellék)terméke a gyermek és ifjúkori szabadidő, amelynek csak egy része intézményesült. A nem intézményesített szabadidőben egyre fontosabbá válik az elektronikus média, kezdetben a rádió, majd a televízió és ma már az internet tölti ki a szabadidő nagy részét. A szabadidő elektronikus gyarmatosításáról tanúskodnak az időmérleg-vizsgálatok is. (Nyeste, 2003)

A szabadidő nem intézményesült és intézményesült terei mellett olyan közegekben és tevékenységek mellett is helyet szorítanak számára, amelyeket korábban a család, az iskola, vagy éppen a munka uralt. A családi vacsora alatt frissített Facebook-állapot, a tanóra alatti internetes csevegés mindennapos tevékenység, amely nem ritkán a szocializációs közegek konfliktusával28 jár együtt.

\footnotetext{
${ }^{26} \mathrm{~A}$ kötelező iskolai népoktatás követelményét először Luther fogalmazza meg, az 1500-as években, de hosszú időnek kellett eltelnie ahhoz, hogy általános gyakorlat lehessen. Magyarországra vonatkoztatva az első lépést a Ratio Educationis (1777) jelentette, amely kísérletet tett az állami oktatási rendszer kialakítására. Egy 1845-ös kormányrendelet már pénzbírság kiszabását is elrendelte a gyermekét nem iskoláztató szülőre. Habár a törvényi háttér és az infrastruktúra rendelkezésre állt a gyakorlatban az iskola korántsem volt általános. Fényes Elek 1857 -es statisztikája szerint Magyarországon az iskolaképes gyerekeknek mindössze 61 százaléka volt az oktatási rendszerben (ugyanekkor Csehországban 93, Alsóés Felső Ausztriában 96-97 százalék). (Szebenyi, 2001)

${ }^{27}$ Habár a hagyományos és az új média meglehetősen sok tekintetben különbözik egymástól a konvergencia folyamatainak köszönhetően az integráció irányába mutat, az eszközök a tartalmak konvergenciájának eredményeképpen akár egy közegként is értelmezhetjük mindazt, ami a hagyományos és az új médiatérben megjelenik.

${ }^{28}$ A szocializációs közegek konfliktusa nem a harmadlagos-negyedleges közeg belépésével jelent meg. Az általános és kötelező közoktatás bevezetését is konfliktusok kísérték, ráadásul az iskola nem pusztán az ott töltött időt osztotta be, hanem a házi feladat révén a családi közeget is ugyanúgy gyarmatosította, ahogy napjainkban az infokommunikációs eszközök keresik helyüket a különböző terekben, így az osztálytermekben is. Az iskolában megjelenő mobiltelefonok, multimédiás eszközök és az ezekhez kötődő multitaskingról szóló legfrissebb vizsgálat szerint minden második diák szöveges üzeneteket ír/fogad, minden negyedik közösségi oldalakat használ a tanóra alatt. (Burak, 2012)
} 


\section{Negyedleges szocializációs hatások a generációk karakterében}

A multitasking jelenségével foglalkozó kutatások egybehangzóan megállapítják, hogy a demográfiai szempontból az idősebbek kisebb gyakorisággal végeznek párhuzamos tevékenységet, főleg ha médiafogyasztásról van szó. A jelenség okát többen a szocializációban látják, miszerint az idősebb generációk olyan környezetben nőttek fel, amelyben az offline források (pl. nyomtatott sajtó) voltak jellemzőek szemben a mai kor képernyőivel (Ahlers, 2006), amelyek nem csupán teret engednek, hanem kifejezetten ösztönzik a párhuzamos fogyasztást.

Amennyiben a szocializációs hatások képesek tartósságot felmutatni és hatókörük kiterjed a társadalmi normák elsajátításának legfontosabb életszakaszára - amely a gyermek- és fiatalkor - meghatározhatják egy-egy generáció karakterét is. Visszatekintve a közelmúltra magunk tanúi lehettünk szocializációs (fél)közegek születésének (információs társadalom) és eltűnésének (sorkatonaság) is. A harmadlagos és negyedleges szocializációs közeg befolyásoló hatásai megjelennek az egyes generációs felosztásokban is, mint a fiatal generációknak önálló karaktert adó jellemzők. A generációs felosztás sokféle lehet, főleg ami a generációs határokat illeti29. Nagyjából a következő generációkról beszélhetünk, megjegyezve azt, hogy leginkább az Egyesült Államokra és Nyugat-Európára érvényes generációs felosztások Magyarországon nem minden esetben igazak:

- Veteránok: A II. világháború előtt születettek generációja ${ }^{30}$, más néven csendes generáció. Ők azok, akik az elektronikus médiával többnyire fiatal felnőttként ismerkedtek meg, az infokommunikációs forradalommal legfeljebb aktív koruk végén kerülhettek kapcsolatba.

- Baby boom nemzedéke: Az ún. baby boom II. világháború után következett be, a generáció határai 1946 és 1964 a U.S. Census Bureau alapján. A baby boom nemzedéke nem csak létszámában, de évfolyamait tekintve is nagy generációnak számít, amelynek nemzedéki mivoltát a születési évek mellett kulturális

\footnotetext{
${ }^{29}$ Pontos határokat nem is érdemes megfogalmazni, hiszen elég nehéz amellett érvelni, hogy miért tartozik valaki, aki történetesen X év december 31-én született más generációhoz mint az aki X+1 év január 1-én született. A tapasztalatok azt mutatják, hogy a határokat illetően leginkább 3-4 évfolyamnyi átmeneti korosztályban kell gondolkodni.

30 Tari (2010) szerint a húszas, harmincas években születettek tartoznak ide.
} 
tartalma ${ }^{31}$ is meghatározza. Ez az a nemzedék, amely többnyire már gyermekkorában találkozik az elektronikus médiával, esetükben főleg a televízió óriási hatásáról beszélhetünk. Az információs társadalomba már felnőttként, aktív életük alatt kapcsolódnak be.

○ Magyarországon az 1950-1956 közötti Ratkó-korszak feleltethető meg a nyugati baby boomnak. Ez a generáció szocializációs közegeit tekintve meglehetősen különbözik a nyugati megfelelőitől. Gyermekkorát és ifjúságát meghatározzák a szocialista ideológia által uralt iskolai és szabadidős terek. A nyugati baby boom generáció határait figyelembe véve, elmondható, hogy a magyarországi 1946-1964-es kohorsz sokkal kevésbé tekinthető televíziós nemzedéknek. Magyarországon 1957-ben indult meg, heti három adásnappal a rendszeres televíziós adás, amely 10 évvel később is csupán egymillió előfizetővel bírt.

- X generáció: A baby boom nemzedékét követő X generáció születési évszámbeli határai nehezebb meghatározni, mint az előző generációk esetében tehettük. X generációról az 1960-as évek közepétől az 1970-es évek végéig32, az 1980-as évek elejéig születettekkel kapcsolatban beszélhetünk. Az X generáció tagjai technikailag már az információs társadalomba születtek ${ }^{33}$ ami azt jelenti, hogy jó részük a különböző infokommunikációs eszközökkel már aktív korukat megelőzően, gyermekként, fiatalként ismerkedhetett meg.

○ Magyarországon az X generáció derékhadát a Ratkó-korszak unokái adják, akik még voltak úttörők, tehát a szocializmusban szocializálódtak, a rendszerváltást tinédzserként, vagy fiatal felnőttként élték meg. A nyugati $\mathrm{X}$ generációtól való megkésettség jól érzékelhető, a magyar X generáció tagjait, ha a televízió hatását tekintjük leginkább a nyugati baby boom nemzedékéhez hasonlíthatjuk.

- Y generáció: Más neveken Millennium nemzedék (Millennials, Generation We, Global Generation, the Millennial Generation, Generation Next, the Net Generation the Echo Boomers). Az Y generáció tagjai jellemzően a Baby boom és az $\mathrm{X}$ generáció gyermekei, akik valahol a '70-es évek vége és a 2000-es évek eleje

\footnotetext{
${ }^{31}$ Ennek a generációnak a tagjaiból kerültek ki a hippik, az 1960-as és 1970-es évek lázadó szubkultúrája, de a 1980-as évekbeli yuppie-k is.

32 Coupland (1991) éppen 1965 és 1979 között értelmezi az X generációt. (Carrier et al., 2009)

33 Z. Karvalics az információs társadalom megszületését 1961-re teszi. (Z. Karvalics, 2007b)
} 
között születtek ${ }^{34}$. Az Y generáció az információs társadalom generációja, akik az infokommunikációs technológiákat már gyermekkorukban elkezdik használni, ők a digitális bennszülöttek, akik számára az infokommunikációs technológia természetes dolog.

○ A magyarországi Y generáció gyakorlatilag behozta azokat a lemaradásokat, amelyek korábban jellemzőek voltak. Az Y generáció már nagyrészt a rendszerváltás után éli gyermekkorát, a számítógéppel és az internettel, ha otthon nem is az iskolában már mindenképpen találkozik. Az Y generációval kapcsolatban figyelik meg elsőként a korcsoportra általánosan jellemző média és kommunikációs multitaskingot.

- Z generáció: Másképpen (inter)net generáció, vagy éppen maga a multitasking generáció, amelynek határai szintén bizonytalanok. A kezdetek beleérnek az Y generáció életkori határaiba, hiszen már a '90-es években születettektől kezdődően beszélhetünk Z generációról egészen napjainkig35. Ez az a generáció, amely nem ismerte a mobiltelefonok és internet nélküli világot, szocializációs közegeiben egytől-egyig végbement az információs társadalom paradigmaváltása ${ }^{36}$ új eszközöket, szokásokat, kultúrát teremtve.

○ Magyarországon a rendszerváltást követően kialakuló kapitalista, fogyasztói társadalom értékrendszere jelentős hatással volt a fiatalok egész életére, a gazdasági helyzetüktől fogva a kultúra- és médiafogyasztásukig. Habár a magyar piacgazdaság fejlettségében elmarad a nyugati országokétól, így a magyar fiatalok pénztárcája is soványabb európai társaikénál, ugyanakkor a kínálati oldalon több a hasonlóság, mint a különbözőség, ugyanazok a világmárkák, nagyon hasonló, jól körülhatárolható igények, hasonló trendek, gyökeresen eltérő lehetőségek jellemzőek. (Székely, 2008a) A kulturális fogyasztási lehetőségeinek különbsége főleg a budapesti és a vidéki településeken lakók között jelentős. Az egész társadalmi csoportot (az ifjúsági generációkat) érintő különbség az információs társadalomhoz füződő viszony. Már az Y generációra is érvényes, de a Z generáció tagjai között

\footnotetext{
34 Tapscott 1997-ben megjelent munkájában a net generációt az 1980-tól születettekre használja.

${ }^{35}$ A Grail Research 1995 és 2010 között születetteket értelmezi Z generációként.

${ }^{36}$ Gondoljunk akár a háztartások, akár az oktatási intézmények infokommunikációs forradalmára.
} 
teljesedik ki a digitális szocializáció, az infokommunikációs eszközök valóban az életük természetes részét képezik.

- Alfa generáció: Beszélhetünk az előzőekhez képest még kevésbé meghatározható Alfa generációról, egyes helyeken Google generációként is hivatkoznak rájuk. Tagjai már a második évezredben ${ }^{37}$ születtek és egy olyan korban fognak felnőni, amelyet nem ismerhetünk, csak találgathatunk. $\mathrm{Az}$ infokommunikációs technológiák fejlődése óriási léptékű. Az olyan megoldások sikere, mint az SMS és az olyanok kudarca mint az MMS, stb., arra figyelmeztetnek, hogy a korábbi tapasztalatok alapján a mai állapotokból nem következtethetünk a jövőre.

Nem szabad arról megfeledkeznünk, hogy a generációk meghatározása meglehetősen önkényes és a fentiektől eltérő más megoldásokkal is találkozhatunk. A média- és kommunikációs tereket tekintve beszélhetünk még AO generációról (Always-On Generation), amelyet Anderson és Rainie (2012) definiált a 2000 és 2020 között születetteket értve ez alatt, akik az internet és mobileszközök segítségével egymással folyamatosan kapcsolatban vannak. Gyors információfeldolgozás, multitasking, az internet egyfajta külső agyként való használata jellemzi őket. Vágyaik azonnali kielégítésére törekszenek, türelmetlenek és nélkülözik a mély gondolkodás képességét.

A Nielsen piackutató C generációnak (Connect, Create, Contribute, Communicate) nevezi azt a csoportot, amelynek tagjai sokféle kapcsolódásra alkalmas készüléket, táblagépet, okostelefont, stb. használnak. A C generáció - szemben a fentiekkel - nem elsősorban a születési évek alapján, hanem életmód alapján meghatározott csoport. A C generáció tagjai életük jelentős részét töltik online, tájékozottak, folyton keresik az újat, szeretnek újabb és újabb közösségekbe is tartozni.

Tari (2010) a multitaskinghoz tulajdonképpen a szocializációs és környezeti hatásokat társítja, véleménye szerint az ismerős közegekben az egyszerre végzett tevékenységek problémamentesen mennek végbe. A párhuzamos tevékenységekről szólva a vezetni tanulók problémáit hozza fel példaként, akik a figyelemmegosztás kihívását kezdetben rendszerint hatalmasnak érzik. A gyakorlást követően azonban rendszerint problémamentesen kezelik a pedálokat, kormányt és egyéb eszközöket, figyelemmel

${ }^{37}$ A Grail Research 2010-től születettektől beszél alfákról. 
követik a forgalmat és beszélgetés, zenehallgatás sem okoz számukra nehézséget. Ez a gyakorlottság magyarázza azt, hogy míg egy Y generációba tartozónak a számítógépen megnyitott több ablak teljesen természetes addig ugyanez egy idősebbnek kaotikusnak tűnik. (Tari, 2010)

\section{Környezeti hatások}

A globális, nagy társadalmi csoportokat, generációkat érintő hatások mellett jelen lehetnek olyan befolyásoló tényezők is, amelyek hatása nem ilyen kiterjedt, de alapvetően meghatározhatja a multitasking gyakorlásának feltételeit.

Foehr (2006) kutatásából kiderül, hogy a média multitaskingot meghatározó tényezők közül a legmagasabb értéket a médiának való kitettség lehetősége kapta, ezt pedig egy hasonló tényező, vagyis a tévékészülék elhelyezése követi a számítógéphez viszonyítva. Azon háztartásokban, ahol a tévéadás a számítógépnél ülve is követhető a fiatalok esetében nagyobb a párhuzamos fogyasztás valószínűsége, mint azon háztartásokban, ahol ez nem áll fenn. Amennyiben tehát a fogyasztó számára több médium is elérhető, illetve egy helységben található a számítógép és a televízió, jellemzőbb a párhuzamos fogyasztás, mint ott, ahol erre eleve nincs is lehetőség. Korábbi kutatások (Foehr, 2006; Jeong - Fishbein, 2007; Block, 2008) eredményei szerint azon gyerekek, akiknek hálószobájában megtalálható valamilyen médium hajlamosabbak a média multitasking tevékenységekre. (Vega, 2009)

A párhuzamos médiafogyasztás mértékében szerepet kap továbbá a háztartás tévé orientációja, azaz azokban a háztartásokban, ahol a tévé általában be van kapcsolva, (pl. vacsora közben is), illetve nem övezik szabályok a tévéhasználatot, a fiatalok jellemzően egyszerre több médiumot használnak, mint az alacsonyan tévé-orientált háztartásokban élő társaik. (Foehr, 2006; Roberts - Foehr, 2008)

A médiumok elérésének fontosságát Pilotta és szerzőtársai (2003) is megerősítik. Eszerint a párhuzamos tévénézés és internethasználat este 7 és 11 óra között a legjellemzőbb, vagyis akkor, amikor a televíziós kínálat - a főműsoridő jellegből következően - a legerősebb. Az, hogy milyen médiatermékek és szolgáltatások érhetők el a fogyasztó számára egy adott pillanatban, nagymértékben meghatározza, hogy milyen módon történik a fogyasztás. 


\subsubsection{SZOCIODEMOGRÁFIAIJELLEMZÖK}

A szociodemográfiai jellemzők általában jó magyarázói a fogyasztási szokásoknak és ennek megfelelően a kulturális- és médiafogyasztási szokásoknak is. Gálik (2003) megemlíti, hogy a társadalmi státus és a médiafogyasztás kapcsolatát például már a hetvenes-nyolcvanas években is bemutatták, magyarországi kutatásokban is (Szekfú, 1976; Angelusz, 1983).

A munkám szempontjából legfontosabb vizsgálandó szociodemográfiai jellemző az életkor. A fiatalok számos okból tekinthetők - Marc Prensky (2001) szavaival élve digitális bennszülöttnek (digital natives). Ők azok, akik elsőként képesek elsajátítani az új technikai eszközök használatát. Az ilyen ismeretek elsajátítása nem pusztán kevésbé megterhelő a netgenerációo ${ }^{38}$ számára, hanem spontán és természetes módon történik (Rushkoff, 1996), továbbá e generáció tagjai nemcsak magukévá teszik, hanem a mindennapokban használják és a maguk képére formálják ezeket az eszközöket és tartalmakat. Ez a mindennapos használat nagymértékben átalakítja az információszerzési - információfogyasztási, kommunikációs és médiafogyasztási szokásaikat, azok egyre inkább eltérnek az idősebbek szokásaitól. (Prensky, 2001)

Az ifjúság megkülönböztetett helyzete (információs társadalmi szempontból) világosan megmutatkozik, amint a nemzetközi infokommunikációs technológiákhoz kapcsolódó hozzáférési és használati indexeket vizsgáljuk, ahol Magyarország - a lakosság egészét tekintve - rendre rosszul szerepel, ugyanakkor a korosztályos bontások szerint az ifjúság együtt mozog a globális változásokkal. 2011 év közepén a magyar társadalom több mint 60 százaléka, ezzel szemben a fiatalok (15-24 évesek) kilenctizede ${ }^{39}$ használt internetet- a tizenévesek esetében ez az arány még magasabb. A kutatók számára világossá vált, hogy ez a nemzedék sok szempontból különbözik más generációktól. Ennek a generációnak három olyan fontos jellemzője van, amely a szolgáltatásokat tervezők szempontjából különösen fontos (Z. Karvalics, 2006):

- multitasking: egyidejűleg több csatornán „fogyasztanak” (az együttes fogyasztásuk meghaladja az egy fő által „fizikailag” elérhető mennyiséget). Hazai

\footnotetext{
${ }^{38}$ Elterjedt rövidítése szerint: $\mathrm{N}-\mathrm{Gen}$

${ }^{39}$ Az NRC Piackutató 2011. harmadik negyedévi adatai szerint 61 százalék a 15-69 éves populációban, míg a 15-24 évesek 88 százaléka internetezik.
} 
és nemzetközi kutatások eredményei szerint a heti médiafogyasztással több idő megy el, mint egy teljes állással. 2007-es adatok szerint egy átlagos nem internetező több mint 40 órát, egy internetező több mint 50 órát tölt médiával hetente. (Székely, 2008b) Roberts és Foehr (2008) ezzel kapcsolatban arra figyelmeztetnek, hogy ugyan a párhuzamos médiafogyasztás a tinédzserek rendszeres tevékenysége, de ez főként a médiának való kitettséget jelenti és kevésbé a valódi médiahasználatot.

- info-support: környezetüktől egy ideje információs segítséget igényelnek a technológiai támogatás (tech-support) mellett.

- nagy részükben nincs semmilyen reflektív tudatosság a tipikus és megszokott internet-használatuk (pl. letöltés, fájlcsere) jogi-intézményi környezete iránt. Az Ifjúság2008 adatai szerint a fiatalok komoly CD-DVD gyűjteménnyel rendelkeztek otthonukban, amelyeknek mintegy fele másolt lemez volt. (Szabó - Bauer, 2009)

A digitális nemzedék jellemzőit már többen is megkísérelték összefoglalni. Prensky (2001) alapján a digitális bennszülöttek jellemzői a következők: gyorsan befogadják az információkat; az információkat párhuzamosan dolgozzák fel, tevékenységeiket szimultán végzik; a szöveg helyett a képet és a hangot preferálják; előnyben részesítik a véletlenszerű kapcsolódásokat (hipertext); kitűnően dolgoznak hálózatban; vágyaik azonnali és gyakori kielégítésére törekszenek; előnyben részesítik a játékot a „komoly” munka helyett; a technológiában a kényelmetlen, de szükségszerű társ helyett barátot látnak.

Természetesen nem mindenki osztja a fiatal korosztályokhoz kapcsolódó optimista nézeteket. Carr (2010) legfrissebb könyvében sokat foglalkozik azzal, hogy az infokommunikációs eszközök - elsősorban az internet - egyszerű és konyhakész megoldásai leépítik a gondolkodást és végeredményben elbutítanak. A hipertext, azaz a szövegek egymásba kapcsolódása egyre felületesebbé teszi az olvasást, a gyors előszűrt keresések megspórolják a mély gondolkodást. A Carrhoz hasonlóan gondolkodók elsősorban az elmélyülés képességét hiányolják az információs társadalomban szocializálódott korosztályok esetében, felületes tudást, gyorsabb felejtést, ráadásul az egymást átfedő tevékenységek révén a hatékonyság helyett hatékonyságcsökkenést érzékelnek. Hargittai (2010) empirikus adatokra is támaszkodó munkájában arra hívja fel a figyelmet, hogy a digitális bennszülöttek infokommunikációs technológiákhoz 
kapcsolódó tudása nem olyan általános és magától értetődő, mint ahogy azt sokan feltételezik. Hargittai megfigyelései arra engednek következtetni, hogy a digitális generációkon belül is léteznek különbségek a felhasználói szokásokban és készségekben egyaránt, amelyeket az olyan szociodemográfiai jellemzők magyaráznak, mint a gazdasági helyzet, vagy a származás.

A multitasking életkori határaira utalva Wallis (2010) Anderson 2008-as megfigyeléses vizsgálatának eredményeit idézi, amelyből kiderült, hogy a csecsemőkorúak megszakítják a játékot, ha a televízió be van kapcsolva a háttérben. A kisgyermekek 2 éves korukra tanulják meg játék mellett nyomon követni a televízióból, vagy a társadalmi interakciókból ${ }^{40}$ származó audio ingereket is. Anderson szerint ebben az életkorban jelenik meg a média multitasking legkorábbi formája, kérdés azonban, hogy hol van (ha van egyáltalán) a jelenség felső életkori határa.

A szociodemográfiai jellemzők közül az életkor mellett a szimultán tevékenységek szempontjából kiemelendő a nem szerepe. Foehr (2006) megfigyelései alapján elmondható, hogy a lányok körében jellemzőbb a multitasking, mint a fiúk esetében. Ez a megállapítás összeegyeztethető azzal a sztereotípiával, hogy a nők a gyereknevelés miatt folyamatosan párhuzamos tevékenységeket folytatnak. (Roberts - Foehr, 2008) Alperstein (2005) az internethasználat és a televízió nézés párhuzamosságát vizsgálva nem talált jelentős különbséget a férfiak és a nők között.

Criss (2006) a multitasking nemek közötti különbségét laboratóriumi kutatással vizsgálta. Azt találta, hogy a párhuzamos tevékenységek végzése közben elért teljesítményben mennyiségi szempontból nem volt különbség a nők és a férfiak között, de a pontosság szempontjából a nők szignifikánsan jobb eredményt értek el, mint a férfiak.

Vega (2009) mások munkái alapján (Floro - Miles, 2003; Block, 2008) összefoglalja a multitaskingot magyarázó szociodemográfiai jellemzőket, amelyek a következők: az életkor, a nem, az iskolázottság, a foglalkoztatottság, a háztartási bevételek, a kulturális státusz. Míg a párhuzamosság dichotóm felosztását a szociodemográfiai jellemzők jól magyarázzák, Kenyon (2008) eredményei szerint a párhuzamos tevékenységekkel

${ }^{40}$ Christakis (2009) vizsgálata szerint a háttér televíziózás csökkenti a vokális interakciókat a szülők és gyermekek között, továbbá a kisgyermek önálló megszólalásait is. 
töltött idő nem áll összefüggésben olyan tulajdonságokkal, mint az életkor, az anyagi státusz, vagy a lakhely.

\subsubsection{KOGNITÍV SZEMPONTOK - PSZICHOLÓGIAI MEGKÖZELÍTÉSEK}

A tudományágak közül a pszichológiát foglalkoztatja legrégebben a feladatok együttes elvégzésének jellegzetessége ${ }^{41}$. A média multitaskingot a háttérfogyasztás felől megközelítve Gálik és Urbán (2008) felhívják a figyelmet pszichológiai kísérletek tapasztalatára, hogy a minket egyszerre érő ingerek egy részét képtelenek vagyunk feldolgozni és tárolni a rövidtávú memóriánkban. A pszichológusok közül a legtöbben arra a következtetésre jutnak, hogy a kognitív rendszer többfeladatos feldolgozása rontja a teljesítményt, amely megállapítást olyan kísérletek igazolnak, mint például a számsorok megjegyzési képességének romlása tévézés közben. A több feladat feldolgozását az is nehezítheti, ha ugyanarra az érzékszervünkre kell hagyatkoznunk, szemben azzal, ha különböző formában (pl. hang és kép) érkeznek a különböző feladatok. (Baron, 2006) Stroop (1935) kísérletében színek neveit írta fel más színnel, aminek következtében az ellentétes információk megnehezítették az olvasást bizonyítva az ellentétes információk feldolgozásának nehézségét. (Estes, 1976) A párhuzamos tevékenységek koncentrációcsökkentő hatására más források is felhívják a figyelmet (Wallis, 2006; Jain, 2007; Hembrooke és Gay, 2003). Vega (2009) Block (2008) munkájára hivatkozva a koncentrációs problémák mellett az internetfüggőség hatását is megemlíti.

Léteznek azonban olyan munkák is, amelyek ellenkező következtetésre jutnak. Stephens és munkatársai (2008) idézik Dahle 1954-es kutatását ${ }^{42}$ ahol a szimultán IKT használat vizsgálata során kiderült, hogy az információ egyszerre orális (face-to-face) és írott

\footnotetext{
${ }^{41}$ A figyelem megoszthatóságát Jevons (1871) egyszerủ kísérlettel vizsgálta. Egy-egy marék babot dobott egy tálcára, majd egy pillantással igyekezett megbecsülni, hogy hány babszem van a tálcán. A kísérletet ezernél is többször ismételve azt találta, hogy három-négy babszem esetében a becslése hibátlan, míg öt vagy több darab esetében már előfordulnak hibák (öt darabnál 95\%, hat darabnál 82\%, hét darabnál 72\%, nyolc darabnál 56\%, stb. volt a helyes tippek száma). (Cowan, 2005) Jevons kísérlete az mutatta meg, hogy a figyelem által egyszerre rögzíthető tárgyak száma véges. Woodworth és Schlosberg (1954) átlagosan 7-8 tárgyról beszél. (Estes, 1976) A kognitív tudományok a multitaskingot másodpercek töredékeinek szintjén tanulmányozzák. (Burgess, 2000; Carlson - Sohn, 2000) Megállapításaik (Just et al., 2001; Rubenstein et al., 2001) szerint a multitasking visszafoghatja a produktivitást. (Spink et al., 2007)

${ }^{42}$ Dahle, T. L. (1954): An objective and comparative study of five methods of transmitting information to business and industrial employees. Speech Monographs, 21
} 
csatornákon történő közvetítése nem, hogy rontotta, hanem egyenesen kedvezett megértésnek. Hsia 1968-as vizsgálata is alátámasztotta Dahle megállapításait, bemutatva azt, hogy az üzenettovábbítás pontossága megnövekedett azáltal, hogy a hangalapú közlés kiegészült vizuális információkkal. Hsia továbbá amellett érvelt, hogy nem okoz mindenképpen túlterhelést az, hogy egyszerre több csatornán fogadnak információkat, sőt az egyes csatornák inkább kiegészítik egymást, nem interferálnak (between-channel rendundancy). (Stephens et al., 2008) Spink és munkatársai (2007) kognitív pszichológusok munkáira (Ishizaka et al., 2001) hivatkozva a priorizált és a nem-priorizált multitasking folyamatok közötti különbségre hívják fel a figyelmet. E feltevések mellett szól az egycsatornás elmélet (single channel theory) (Schweickert és Boggs, 1984), amely szerint a fő tevékenység korlátozza az emberek kapacitását az egyidejű mentális folyamatok esetén ${ }^{43}$. Kenyon és Lions (2007) szerint három attribútum határozza meg, hogy mely tevékenység mennyire alkalmas párhuzamosságra: (1) tevékenység helytől és időtől való függősége; (2) a tevékenységgel való elfoglaltság folytonosságának szükségessége; (3) az aktív vagy kognitív figyelem szükséges mértéke. (Kenyon, 2008)

Kirsch (2000) azonosította a kognitív túlterhelés (cognitive overload) fogalmát, ami arra utal, amikor az információkkal való túlterhelés (ahol az információ már nem segítség, hanem akadályozó tényező) hozzáadódik a multitaskinghoz és a tevékenységek félbeszakításához. West (2007) a könyvtári keresésekkel kapcsolatban megfogalmazza, hogy az információs túlterhelés ${ }^{44}$ hozzájárul a technostresszhez (technostress). (Bawden - Robinson, 2009) Stephens és munkatársai (2008) kitérnek Broadbent (1958) állítására miszerint az információs túlterhelődés több csatorna együttes használatával valószínűbbé válik. Hsia (1968) vitatkozok ezzel az állítással, kutatásai szerint a

\footnotetext{
43 Vega (2009) az összetett-erőforrás elméletekre (multiple-resource theories) (Navon - Gopher, 1979; Wickens, 2002) hivatkozva kifejti, hogy ezek az elméletek meghatározzák, hogy azon feladatok, amelyek az agy különböző erőforrásait kötik le, hogyan tudnak egy időben végbemenni interferencia nélkül, azonban amikor az erőforrások elosztásában konfliktus lép fel, az igényelt erőforrás teljesítményének csak egy részét tudja az egyes feladatok számára biztosítani. A multitasking egyik fő korlátja az ún. válaszszelekciós szűkület (response selection bottleneck), amely nem teszi lehetővé több döntési folyamat egyidejű kezelésének képességét - amikor konkurens tevékenységek zajlanak, a prefrontális kérgi terület sorba állítja a válaszokat, ami késleltetett feladatmegoldásokhoz vezet. (Dux et al., 2006) Bizonyított, hogy az emberek két feladatot hatékonyan tudnak végezni, ha ezek már begyakorlottak (Schumacher et al., 2001) - mivel az emberek egy időben csak egy döntési folyamatot tudnak kezelni, ahhoz, hogy egyszerre kettőt is le tudjanak bonyolítani, az egyiket automatizálniuk kell .

${ }^{44}$ Bawden és Robinson (2009) az információs túlterhelést egészen a Biblia lapjaihoz vezeti vissza: „Mindezekből, fiam, intessél meg: a sok könyvek írásának nincs vége, és a sok tanulás fáradságára van a testnek.” (Prédikátor 12:14; Károli Gáspár ford.)
} 
többcsatornás információátadás során (pl. audio és vizuális ingerek egyszerre) az üzenetátadás sikeresebb lehet, ugyanis a több csatorna egymást erősítve nem zavaró tényezőként ${ }^{45}$ van jelen. (Stephens et al., 2008)

Síklaki (2011, pp:156) idézi Herbert A. Simon találó megfogalmazását, miszerint „az információ a befogadóinak figyelmét fogyasztja el”, amiből az következik, hogy az információ gazdag környezetben az egy-egy információegységre fordított figyelem kisebb, mint az információ szegény környezetben. Ez kétségtelen igaz, azonban az információk gazdagsága nem feltétlenül csökkenti a hatékonyságot, sőt. Például az azonnali üzenetküldő szolgáltatások használata mellett szinte mindig jelen van valamilyen más, fő tevékenység tehát a figyelem megosztása is gyakori. Ugyanakkor az azonnali üzenetküldők lehetőséget biztosítanak arra, hogy a végzett főtevékenység során hatékonyabb megoldásokat, új információkat lehessen becsatornázni. „Ennek az üzemmódnak fontos mellékhatása, hogy a gondolkodás a többiekkel fenntartott interakció révén színesebb, változatosabb lesz, kevésbé lehatárolt, mint az egymagában tanuló vagy feladatot megoldó ember esetében".

Spink és társai (2007) rámutatnak arra, hogy az internetes keresések gyakran több információs feladatra irányulnak egy-egy alkalom során ${ }^{46}$. Az információs viselkedés (information behaviour) magában foglalja az információkeresést, -raktározást (foraging), -értelmezést, -rendezést és a felhasználást egy vagy több témát illető integrált folyamatban. Mindez azt jelenti, hogy az információs viselkedés feladatok sorozatából áll, amelyeket a feladatok közötti váltások kapcsolnak össze. Ilyenformán a multitasking egy összekötő folyamat, ami az emberi koordináció révén kialakítja az információs viselkedést ${ }^{47}$.

Ophir és munkatársai (2009) megkülönböztetik a gyakori (heavy media multitaskers) és az enyhe média multitaskingot gyakorlókat (light media multitaskers) egy kérdőívre

\footnotetext{
${ }^{45}$ A multitasking vonatkozhat kognitív és fizikai akciók kombinációira, két vagy több feladatra konkurens illetve szekvenciális módon, beleértve a váltásokat a feladatok között. (Spink et al., 2007)

${ }^{46}$ Spink 2004-ben egy könyvtárhasználó információgyủjtési viselkedését tanulmányozta, négy egymástól független információkeresési feladat megoldása során 17 feladatváltással. A feladatváltások okait a könyvtárazó következőkben látta: első körben azokat a feladatokat próbálta megoldani, amelyek jobban érdekelték. Miután megunta az egyik feladatot, elkezdett érdeklődni egy másik iránt, és azzal akart inkább foglalkozni. A könyvtárban olyan vizuális ingerekkel találkozott, amelyek arra késztették, hogy olyan információkat keressen, amelyeket korábban nem szándékozott. (Spink et al., 2007)

${ }^{47}$ Spink és munkatársai (2007) megkülönböztetik az információs (pl. információkeresési) és a neminformációs (pl. olvasási) feladatokat. Munkájuk egyik fő megállapítása szerint a könyvtárlátogatók jó része multitasking folyamatok során végez információkereső tevékenységet, amelyben helyet kapnak a kommunikációs és nem-információs feladatok is.
} 
adott válaszok alapján. Gyakori multitaskereknek nevezték azokat, akik a média multitasking index - ami a párhuzamosan használt médiumok átlagán alapul - felett, enyhének azokat, akik az alatt teljesítettek több, mint egy szórással. Az irreleváns környezeti hatások kiszűrését tekintve a gyakori multitaskerek rosszabbul teljesítettek, a zavaró tényezők visszahúzták teljesítményüket. A gyakori multitaskerekről elmondható, hogy kevésbé szelektálják a memóriájukba áramló információkat, lassabban tudnak átváltani az egyes feladatok között, nehezebben tudják kiszűrni az irreleváns reprezentációkat.

Az életkori jellemzőket ${ }^{48}$ tekintve a pszichológiai kutatásokban az egyik legfontosabb kérdés, hogy a párhuzamos tevékenységek hogyan befolyásolják a gyerekek agyi idegi struktúráinak fejlődését és kognitív képességeit. Vega (2009) által hivatkozott kutatások (Meyer - Kieras, 1997) szerint a multitasking képessége a felnőttek körében számos kognitív akadályba ütközhet, amelyek az érzékelés, az észlelés és a motoros működés különböző stádiumaiban jelentkezhetnek. A legújabb funkcionális MRI vizsgálatok szerint a gyerekek jobban teljesítenek a párhuzamosságot tekintve a felnőtteknél, valószínűleg azért, mert a figyelmüket jobban ki tudják osztani és ki tudják szűrni a fölösleges információkat a középkorú vagy idősebb felnőtteknél. (Grady et al., 2006; Hamilton, 2008) A multitasking képességének korlátozottságát figyelemhiányos hiperaktivitásban (AHDH) szenvedő 7-13 éves gyerekek körében dokumentálták (Siklos - Kerns, 2004; Chan et al., 2006), jelezve a folyamatos viselkedések monitorozásának, a célorientált tervezésnek és a feladatok teljesítéséhez szükséges stratégiák hiányát. (Vega, 2009)

A kognitív feladatmegoldás képessége mellett a multitasking mértékében szerepet kap a fogyasztó élmény-, vagy szenzációkereső (sensation-seeking) attitűdje, amely arra utal, hogy keresi-e a stimulációkat, vagy sem. Roberts és munkatársai (2008) megfigyelték, hogy a különböző médiumok, elsősorban a videojátékok magas stimulációs hatással bírnak. Az élménykeresők csoportjaiban magasabb volt a média jelenléte, mint azokban a csoportokban, ahol az élménykeresés attitűdje kisebb, továbbá az élménykeresők körében jellemzőbb volta multitasking, hiszen folyamatosan keresik a stimuláló hatásokat, akár egyszerre több forrást is.

\footnotetext{
${ }^{48} \mathrm{~A}$ felnőttek körében végzett kutatások kimutatták, hogy a párhuzamos tevékenységekben a pre-frontális kéreg kognitív és neuroanatómiai rendszerei vesznek részt (Burgess, 2000; Koechlin et al., 1999), de a feladattól függően további részek is bekapcsolódhatnak a multitasking elősegítésébe. (Foerde et al., 2006) (Vega, 2009)
} 
A multitasking káros, vagy segítő hatásaival kapcsolatban nincsenek megnyugtató empirikus tapasztalataink. Egyes kutatások (Green - Bavelier, 2003) szerint a videojátékokkal való játék növelheti a vizuális figyelem megosztásának képességét. Más kutatások (Ophir, et al., 2009) szerint azonban, akik intenzív párhuzamos tevékenységeket folytatnak, rosszabbul teljesítenek a multimédiás környezetekben azoknál, akik ritkábban osztják meg figyelmüket. (Cummings et al., 2010) Becker és munkatársai (2013) megfigyelései alapján elmondható, hogy a média multitasking összefüggést mutat egyes mentális problémákkal (depresszió, szorongás), bár oksági kapcsolatot nem állapítottak meg a kutatók. Wang és Tchernev (2012) arra kereste a választ, hogy mi az oka annak, hogy a média multitasking annak ellenére terjed, hogy a laboratóriumi kísérletek következményként a legtöbbször a hatékonyság-csökkenést emelik ki. Meglátásuk szerint lennie kell olyan pozitív, megerősítő visszajelzéseknek, amelyek a multitasking viselkedést ösztönzik. Kutatásuk szerint a kognitív költségek mellett érzelmi (szórakozás, kikapcsolódás) haszonnal számolhatnak a párhuzamosságot gyakorlók, azaz boldogabbak lesznek.

A fentiekben láthattuk, hogy a multitasking vizsgálatának kognitív megközelítései elsősorban a hatékonyságot helyezik vizsgálatuk középpontjába. A kutatások eredményei arra utalnak, hogy a párhuzamosság nem tekinthető egyértelműen hatékonyság-csökkentő hatásúnak, a hatékonyság mértéke nagyban függ a különböző érzékszervek terhelésétől így a multitasking során végzett tevékenységek kombinációjától, vagy másként a tevékenységek jellegétől.

\subsubsection{A TEVÉKENYSÉG JELLEGE}

A szakirodalmi utalások és a primer kutatási tapasztalatok arra engednek következtetni, hogy a szimultán tevékenységekben nem pusztán az információs társadalom globális hatásai, vagy a szociodemográfiai és egyéni pszichológiai jellemzők érvényesülnek, hanem szerepe van a tevékenység céljának, illetve a média jellegének egyaránt. Roberts és Foehr (2008) a média multitaskingra vonatkozó munkája alapján elmondható, hogy egyes médiumok alkalmasabbak szimultán fogyasztásra, mint mások, például sokan úgy szoktak olvasni, hogy közben zene, vagy a tévé szól a háttérben. Egyes médiumok párosítása tehát logikusabbnak tűnik, mint másoké (pl. zenehallgatás és olvasás a 
számítógépen keresztül probléma nélkül végezhető egyszerre, míg a tévénézés és zenehallgatás, vagy tévénézés és a videojáték már nehezebben összeegyeztethető).

A média és kommunikációs multitasking értelmezhető elsődleges- másodlagosharmadlagos 49 , vagy primer és háttérfogyasztásként, ahol a nem szándékolt háttérfogyasztás már a médiának való kitettség fogalmát használhatjuk. Az új médiatípusok megjelenésével különösen fontossá vált a médiahasználat és a médiának való kitettség megkülönböztetése, főleg a számítógép megjelenése óta, aminek hatására megnőtt a szimultán kommunikáció és médiafogyasztás. (Roberts - Foehr, 2008)

A legerőteljesebb magyarázó modell a párhuzamos tevékenységek közötti eloszlását illetően Baronhoz (2005) fűződik, aki az aktivitások kognitív-szociális egyensúlyára vonatkozóan azt állítja, hogy a magas kognitív megterheléssel járó tevékenységek többnyire elsődlegesek, a szociális aktivitások pedig másodlagosak. (Kenyon, 2008)

Foehr 2006-os eredményei mindezt alátámasztják, azonban több meglepő adattal is találkozhatunk. Figyelemreméltó, hogy a televízió mellett van a legkevésbé jelen más médium, Foehr szerint ez annak köszönhető, hogy a televízió mellett más, nem médiával kapcsolatos tevékenységeket végeznek az emberek. Habár Foehr szerint a tévé mellett történik arányaiban a legkevesebb más médiumot is érintő multitasking, figyelembe kell venni, hogy a tévére fordított idő mennyisége a legjelentősebb, továbbá a televízió a leginkább jellemző másodlagosan vagy többedlegesen használt médium. Az eredményekből kitűnik, hogy a multitasking jelenségének középpontjában a számítógép áll. Többnyire egy számítógépes tevékenység mellett egy másik számítógépes tevékenység zajlik. (Roberts - Foehr, 2008)

A kommunikációs és média multitasking elterjedésének újabb lökést ad az okostelefonok, tabletek, e-book-ok és más hordozható eszközök megjelenése. A többképernyős fogyasztást (multi-screening) vizsgáló kutatásokból kiderül, hogy eszközök számának növekedésével nő a valószínűsége a párhuzamos használatnak. Megfigyelhető továbbá, hogy a helytől független, megszakítható, tevékenységek esetében

\footnotetext{
${ }^{49} \mathrm{~A}$ médiával töltött időt rendkívül nehéz felmérni, hiszen a médiahasználat lehet másodlagos vagy akár harmadlagos tevékenység (pl. bekapcsolt televízió mellett lehet mosogatni, mialatt a fülhallgatón hallgatni a zenét).
} 
kitűnően alkalmazható a multitasking ${ }^{50}$. A tapasztalatok azt mutatják, hogy a hordozható eszközökhöz kötődő média és kommunikációs tevékenységek nem csak a holt idő kitöltésében vannak jelen, hanem egyre gyakrabban jelennek meg más tevékenységekhez társulva, konkurenciát teremtve a figyelemért folytatott versenyben, ami komoly kérdéseket vet fel az alaptevékenység jellegével kapcsolatban. Nyilvánvaló, hogy más kérdéseket kell feltennünk, ha a média és kommunikációs multitasking alapvetően szabadidős kontextusban történik (pl. az esti film alatti online böngészés) és egészen másokat, ha munka, vagy tanulás mellett van jelen valamilyen médium, vagy interakció (pl. zenehallgatás tanulás közben), vagy ha alapvetően egy társas eseményhez kapcsolódik (pl. családi vacsora alatti csevegés a közösségi oldalon).

A tevékenységek jellegének hasonló felosztását megtalálhatjuk Nagy Réka (2005) téziseiben is, aki az internetezéshez kapcsolódóan elkülöníti egymástól az értékes erőforrás-bővítő és a kevésbé értékes rekreációs célú használatot. A következőkben ennek a tevékenységtipológiának egy leágazásával foglalkozom, ugyanis a túlnyomórészt rekreációs célú médiafogyasztás mellett az egyidejű feladatvégzés kétségtelenül az erőforrás-bővítő, azaz komolyabb tevékenységek, főleg a munka és a tanulás mentén vet fel fontos kérdéseket.

\section{Multitasking és multikommunikáció a munkakörnyezetben 51}

Manapság egy irodai munkahely szinte elképzelhetetlen internetre kapcsolt számítógépek nélkül, ahogy az is immáron hosszú évek óta alapkövetelmény a legtöbb munkavállalóval szemben, hogy ezeket az eszközöket használni tudja. Ha csak a magyar statisztikákat vizsgáljuk, láthatjuk, hogy a magyarországi vállalkozások 93 százaléka rendelkezik internet-előfizetéssel. (GfK, 2008) Függetlenül attól, hogy nagyjából az ezredforduló közepétől az internethasználat igazi terepe az otthon lett, a mindennapi internetes tennivalók, mint például a vásárlás, a szabadidős tevékenységek megszervezése, a rádió- és tévéadások, újsághírek követése az online önmegvalósítás (blogok, videó portálok stb.), vagy a személyes kapcsolatok ápolásának lehetősége a

\footnotetext{
${ }^{50} \mathrm{Az}$ okostelefonok felhasználói körében csipegető kultúraként (snacking culture) hivatkoznak erre a jelenségre.

${ }^{51} \mathrm{~A}$ fejezet támaszkodik az Excenter Kutatási Központ „Ügyfélkommunikáció és ügyfélszolgálat az információs társadalomban" címủ kutatásra, illetve az annak tapasztalatiról beszámoló Excenter Füzetek VII. számára.
} 
munkahelyen is felkínálkozik. A tapasztalatok szerint az internet adta lehetőségeket a munkavállalók ki is használják. Egyes kutatások szerint a munkavállalók napi egy és két óra közötti időtartamot szánnak munkaidejükből a személyes célú internetezésre (Beam, 2011). Egyes esetekben a munkahelyi internethasználat az internetezés fő helyszíne. (Burst Media, 2007) Az infokommunikációs eszközök által kínált always on egyre fontosabbá válik a munkavállalók számára is, szívesebben is dolgoznának olyan cégnél, ahol hozzáférhetnek a közösségi oldali fiókjaikhoz. (Hopkins, 2008)

Nemzetközi kutatások ${ }^{52}$ szerint hatékonyságbeli problémákat vet fel ebből adódóan nemzetgazdasági szinten is - jelentős költségekkel járhat a munkaidő alatti magáncélú infokommunikációs eszközhasználat. A hatékonyság csökkenésétől rettegő vállalkozások igyekeznek megakadályozni53 azt, hogy a munkaidő alatt a munkavállalók magánügyeikkel (is) foglalkozzanak. Ugyanakkor, mint ahogy a kognitív megközelítések esetében láthattuk nem olyan egyértelmű a multitasking és a hatékonyság közötti

\footnotetext{
${ }^{52}$ A MyJobGroup.co.uk 2010-es kutatása szerint a brit gazdaság évente 14 milliárd font, vagyis évi 4,7 billió forint kárt szenved az alkalmazottak munkahelyi Facebook és Twitter látogatásai miatt. (MyJobGroup.co.uk, 2010) E kutatást megelőző évben egy hasonló tanulmány szerint az Egyesült Királyságban dolgozó munkavállalók több mint fele ismerte be, hogy munkaidő alatt frissíti a közösségi portálokon bejegyzett profiljait, míg harmaduk elmondta, hogy több mint fél órát tölt ezeken a honlapokon. A Peninsula is megpróbálta számszerűsíteni a munkahelyi privát célú internetezés okozta éves gazdasági veszteséget kutatása alapján, amely mintegy 30,8 milliárd fontot tesz ki. (MFor, 2008) Az internetes tartalmak szürésére és blokkolására szakosodott Websense egy 2005-ben kiadott beszámolójában több, mint évi 178 milliárd dollárra becsülte a nem megfelelő munkahelyi internethasználat okozta termeléskiesést az amerikai cégek körében, ami alkalmazottanként több mint évi 5.000 dollár veszteséget jelent. (Websense, 2005) A Websense tanulmánya éles sajtóvisszhangot váltott ki. Az egyik legérdekesebb felvetés a beszámolóval szemben, hogy vajon egy átlagos dolgozó hány órát tölt a munkájával kapcsolatos tennivalókkal otthonában, a munkaidején túl. (Fisher, 2005)

${ }^{53}$ Az OpenDNS ${ }^{\circledR}$ - a világon a legnagyobb DNS kiszolgáló - 2010-ben jelentést készített a leggyakrabban blokkolt tartalmakról domainekről. A jelentésből kiderül, hogy globálisan (vállalkozások, intézmények, magánszemélyek) leginkább a szexuális, pornográf, ízléstelen és erőszakos tartalmak mellett tiltják a reklámokat, az identitást elrejtő, illetve az online szerencsejátékkal, vagy drogokkal foglalkozó oldalakat. A vállalkozásokra vonatkozóan elmondható, hogy a leggyakrabban tiltott domainek többnyire közösségi oldalakat, ingyenes e-mail szolgáltatások, online piacterek oldalait tiltják. (OpenDNS®, 2011)

A Ponemon Intézet összesen 2100 IT szakembert kérdezett meg világszerte (USA, Franciaország, Ausztrália, Japán, Egyesült Királyság) a webkettes alkalmazásokkal kapcsolatos vállalati policy-ről. A megkérdezett szakemberek többsége igen komoly biztonsági kockázatnak tartja a különböző webkettes alkalmazásokat. Közel a kérdezett szakemberek kétharmada (64\%) nyilatkozott úgy, hogy cége biztonsági rendszerét jelentősen zavarják a webkettes alkalmazások. A Ponemon Intézet nemzetközi kutatása kitért a kockázatok típusaira is. A legfontosabb három kockázatból kettő - amelyeket minden második megkérdezett szakember említett - adatbiztonsági jellegű (vírusok és kártékony programok), míg a harmadik a munkahatékonysággal kapcsolatos. Utóbbival kapcsolatban komoly különbségeket figyelhetünk meg az egyes országok között. A munkahatékonyság elsősorban az angolszász országokban jelent komoly problémát (USA, 63\%; UK 62\%; AU 60\%), míg Franciaországban átlagos (52\%) és Japánban jelentősége eltörpül (26\%) a többi kockázat mellett. (Ponemon, 2010)

$\mathrm{Az}$ amerikai Robert Half Technology 1.400 cég vezető informatikusát kérdezte meg arról, hogy az alkalmazottak számára megtiltják-e a közösségi oldalak látogatását. A válaszadók harmada jelezte, hogy vállalatuknál a dolgozók személyes célból is látogathatják ezeket az oldalakat. (Robert Half Technology, 2011)
} 
kapcsolat. A Melbourne-i Egyetem kutatói által 2009-ben nyilvánosságra hozott eredmények szerint az alkalmazottak termelékenysége megnő abban az esetben, ha interneteznek munka közben. A kutatók egy új fogalmat is bevezettek: munkahelyi szabadidős internetböngészés (workplace internet leisure browsing, WILB). Meglátásuk szerint a személyes célú internethasználat révén az alkalmazottak szellemileg felfrissíthetik magukat és a pihenők után jobb közérzettel foghatnak munkájukhoz. Számszerűsítve a munkaidő legfeljebb húsz százaléka során alkalmazott munkahelyi szabadidős internetböngészés kilenc százalékkal növeli a produktivitást. (Coker, 2011).

Az információs társadalom munka az infokommunikációs eszközök egyre gyakoribb alkalmazása kikezdi a munkavégzés helyének és idejének (tér és idő) megszokott kereteit és egyfajta organikus modellre vált vissza. A történelem során folyamatosan alakult és átalakult a munka és a magántevékenységek pozicionálása. A 19. század elején, a már ipari termelésre váltott gazdaságokban is az extrém hosszú munkaidő (1416, akár 18 óra naponta) a munkatevékenységeket összemosta a háztartási teendőkkel, gyermekneveléssel (a családosok sokszor magukkal vitték a gyereküket is dolgozni). (Kuczi, 2004) Az infokommunikációs technológiával átszőtt munkakörnyezet lehetőséget ad arra, hogy olyan magánjellegű tevékenységeket végezzünk a munkahelyünkön és/vagy munkaidő alatt, amelyre korábban nem volt lehetőség, illetve megfordítva a vasárnapi ebéd mellett céges leveleket olvassunk.

Nem csupán a magán- és munkatevékenységek párhuzamos végzése, hanem kifejezetten a munkához kötődő feladatokkal való zsonglőrködés jelentősége is egyre nő a vállalati körökben (például meetingek közben SMS-írás). (Chudoba et al., 2005; Turner - Reinsch, 2007). (Stephens et al., 2008)

A Stanford Egyetemen tartott multitasking workshop résztvevői egyetértettek abban, hogy a 21. században a szimultán feladatvégzés kiemelten fontos munkahelyi készséggé vált. Egy amerikai kutatás (Spira - Feintuch, 2005) szerint folyamatosan növekszik a megszakítások miatt kárba veszett idő, eredményeik szerint az információs szektorban dolgozók átlagosan mindössze három percet töltenek egy-egy feladat előtt, mielőtt megszakítanák őket. (González - Mark, 2004) Bannister és Remenyi, (2009) idézik Mark és munkatársai megfigyelését miszerint egy átlagos munkavállaló számára 25 percre van szükség a megszakítást követő újrafókuszálásra. 
A munkakörnyezetben megvalósuló párhuzamos tevékenységek kutatása több évtizedes múltra tekint vissza ${ }^{54}$, miközben a kommunikációs és média multitasking friss területnek tekinthető. A korábbi munkákban elsősorban a vállalati kommunikációban megjelenő egyes infokommunikációs eszközöket külön, feladatokhoz rendelve vizsgálták (Daft - Lengel, 1984, 1986; Daft et al., 1987), az újabb munkákban rámutattak a kombinált IKT használat jelentőségére és azok szekvenciális illetve szimultán használatára is (Chudoba et al., 2005; Munkejord, 2007; Osterlund, 2007; Reinsch et al., 2008; Rice, et al., 2004; Stephens, 2012; Stephens, et al., 2008; Turner - Reinsch, 2007; Watson et al., 2007).

Turner és Reinsch (2007) az egyidejű, többcsatornás kommunikációt (multicommunication) vizsgálták a munkakörnyezetben kvalitatív interjús és kérdőíves módszerrel. A multikommunikáció fogalmát a polikronicitás (polychronicity) ${ }^{55}$ és a multitasking fogalma mentén alakítják ki. A szerzők szerint a multikommunikációt érdemes megkülönböztetni a multitasking egyéb formáitól, hiszen a kommunikáció interaktív. A multikommunikáció definíció szerint legalább két, egymást átfedő, szimultán beszélgetésben való részvétel különböző partnerekkel - ez gyakran történik a telefonhívások és az online csevegések során. Reinsch és társai (2008) megállapították, hogy a multikommunikáció gyakorlását alapvetően befolyásolják a vállalati normák. Állításuk szerint, ha valaki úgy érzi, hogy a produktivitás követelménye fontosabb a teljes figyelem vagy az azonnali válaszok követelményénél, akkor multikommunikációra hajlamos. (Reinsch et al., 2008).

Számos újságcikk is foglalkozik a területtel és figyelmezteti olvasóit a hordozható kommunikációs eszközökhöz kötődő multitasking terjedésére, kiemelve a munkahelyi viszonyokra és a magánéletre gyakorolt negatív hatásokat (Hwang, 2002; Israel, 2006; Kirn, 2007). Kirn (2007) rámutatott arra, hogy egyre nő azon megnyilatkozások száma, amelyek arról próbálnak meggyőzni minket, hogy folyamatosan több dolgot kell egyszerre csinálnunk és készen kell állnunk a kommunikációra minden pillanatban.

\footnotetext{
${ }^{54}$ Bannister és Remenyi, (2009) hivatkozik Mintzberg munkáira: Mintzberg, H. (1973): The Nature of Managerial Work, Prentice Hall, Englewood Cliffs, NJ. Mintzberg, H. (1970): Structured observation as a method to study managerial work, The Journal of Management Studies, 7. Mintzberg megállapította, hogy a menedzserek munkavégzésük során nagyjából egy-egy percet tudnak egy adott feladatra koncentrálni. ${ }^{55}$ A polikronik-monokronik (polychronic-monochronic) koncepcióját Edward Hall (1959) alakította ki a különböző kultúrák időfelhasználásának antropológiai szempontú kutatása során. A polikronicitás az egy időben végzett a több tevékenységre, gyakorlatilag ugyanarra a viselkedésfajtára utal, mint a multitasking. Hall szerint egyes kultúrákban jellemzőbb polikronicitás, mint másokban, pl. Dél-Európában elterjedtebb, mint Észak-Európában. (Turner - Reinsch, 2007)
} 
Turner és Reinsch (2007) interjús tapasztalatai szerint a multikommunikáció gyakran előfordul a cégeknél, minden alany (20 fő) beszámolt ilyen tapasztalatról, és többnyire hatékonynak találta azt ${ }^{56}$. A kutatásból kiderül, hogy az üzleti kommunikációs felek képesek személyes figyelmüket több egyszerre zajló beszélgetés között megosztani. A legtöbb interjúalany négy szimultán csevegést tud párhuzamosan kezelni saját bevallása szerint. A kutatás eredményei arra engednek következtetni, hogy a multikommunikáció valószínűségét meghatározzák az egyén döntései (hajlandósága a multikommunikációra) az aktorok közötti beosztásbeli viszonyok, illetve az üzenetek egyértelműsége (komplexitása). A kutatók Yates, Orlikowski és Okamura (1999) alapján megkülönböztetik a mennyiségi és minőségi multikommunikációt, mennyiségi jellemzőnek tartva az egy téma köré csoportosuló több aktort (pl. egy-egy projekt megbeszélése), illetve a minőséginek azokat az eseteket, amikor különböző témákban, különböző társadalmi szerepekben folytatnak interakciókat (pl. supervisor, beosztott, kolléga, barát, szülő). (Turner - Reinsch, 2007)

Stephens és Davis (2009) kutatása a vállalati megbeszéléseken végzett az infokommunikációs eszközökhöz kötődő átfedő tevékenységeket vizsgálta. A vállalati megbeszélések (meetingek) során az résztvevők számos a megbeszéléshez közvetlenül nem kötődő tevékenységgel vannak elfoglalva (más projekteken gondolkoznak, stb.). Az infokommunikációs eszközök nem csak a megbeszéléshez kapcsolódóan használhatóak fel, hanem ezen egyéb tevékenységekben is az emberek segítségére lehetnek, aminek egyre nő a jelentősége a hordozható készülékek terjedésével. A vezeték nélküli internetszolgáltatások lehetővé teszik az felhasználók számára, hogy egyszerűen és gyorsan végezzenek több tevékenységet egyszerre. Számos kutatás szerint az okostelefonok a leggyakoribb eszközei a multitaskingnak (Mazmanian et al., 2006).

Garrett és Danziger (2007) a munkahelyi IM (instant messaging) használatot tanulmányozták, és alapvető összefüggéseket találtak az IM és a multitasking között. A gyakori online csevegők körében valószínúbb volt a párhuzamosság, mint az azonnali üzenetküldőket kevésbé használók esetében. Az IM felhasználók kevésbé számoltak be megszakítások során zavaró hatásról, mindamellett gyakrabban folytattak a számítógéphez kötődő magántermészetű és munkához kötődő kommunikációról.

\footnotetext{
${ }^{56}$ Ezt erősíti Farhoomand és Drury menedzserek között végzett interjús kutatása, ahol az alanyok 16 százaléka számolt be arról, hogy túlterhelődnek, amikor ugyanazt az információt több csatornán kapják meg. (Stephens et al., 2008)
} 
Habár a multikommunikációval kapcsolatos kutatások főleg a többszörösen mediatizált beszélgetésekre irányulnak, a jelenség a szemtől szembeni találkozókon is előfordul, ugyanis az offline meetingeken résztvevők laptopokon és mobiltelefonokon keresztül másokkal is kommunikálhatnak. Mindemellett ezen eszközöket jegyzetelésre, internetezésre is használhatják és használják is a találkozók alatt.

Stephens és Davis (2009) úgy találták, hogy a technológiai jártasság növekedésével növekszik a megbeszélések során történő infokommunikációs eszközökhöz kötődő multitasking valószínűsége, míg a túlterheltség hatása nem szignifikáns. Stephens és munkatársai (2008) Farhoomand és Drury menedzserek között végzett interjús kutatását idézik, ahol az alanyok mindössze 16 százaléka számolt be arról, hogy túlterhelődnek, amikor ugyanazt az információt több csatornán kapják meg. A multitasking valószínűsége a szimultán tevékenységek vállalati elfogadottságával is összefügg. A vállalati elfogadottságot kétféleképp operacionalizálták: (1) mások multitasking tevékenységének percepciója a meetingeken (2) mások vélekedése a multitaskingról - mindkét verzió szignifikánsan valószínűsíti a multitaskingot (főleg az észlelés, azonban ezen változók mellett a technológiai jártasság elveszíti szignifikáns hatását). (Stephens - Davis, 2009)

Chudoba és társai egy technológiai cégnél készítettek interjúkat, és úgy találták, hogy a menedzserek két módszerrel próbálták visszafogni a multitaskingot a meetingeken, egyrészt véletlenszerűen ellenőrizték a résztvevőket, másrészt bevezették a laptop down policy-t, azaz a munkatársaknak le kellett csukniuk a laptopjukat.

Bannister és Remenyi, (2009) hivatkozik Aral és munkatársainak 2007-es vizsgálatára, amelynek eredményei szerint a párhuzamosság pozitív hatással van a termelékenységre, azaz azok a munkavállalók, akik gyakorolták a multitaskingot hatékonyabbak voltak társaiknál, ugyanakkor egy-egy projektet tekintve lassabb munkateljesítményt nyújtottak. Nem világos, hogy mi lehet a magyarázat a hatékonyság és a projektek összteljesítménye közötti ellentmondásra, talán pont az, hogy a multitaskingot gyakorlók egyszerre több projekten dolgoznak. A multitasking hatása a termelékenységre egy fordított U görbére hasonlított: a termelékenység javult, amikor egy feladatról több feladatra váltottak a munkavállalók, azonban a feladatok számának növekedésével a termelékenység előbb egyenletessé vált, majd egy kritikus pontot követően meredeken csökkent. 


\section{Multitasking és tanulás}

Az információs társadalomban az információkhoz való hozzáférés módja alapvetően megváltozott, a tudás megszerzése sok szempontból egyszerűbbé vált. A digitalizáció lehetővé teszi a legkülönbözőbb tartalmak (szöveg, kép, multimédia) tárolását és megosztását. A World Wide Web elterjedésével a felhasználók digitalizált információk tömkelegéhez férhettek hozzá. A web 1.0 korában jellemzően egyirányú folyamatként a internetezők letöltötték és felhasználták a tartalmakat, míg a web 2.0-ás alkalmazások korában már meg is osztják és létre is hoznak tartalmakat.

Az új tanulási formák, a gyorsan elérhető információk alapvető változást jelentenek az oktatási rendszer szereplői számára is, például a tanár már nem a tudás egyedüli letéteményese, állításai azonnal ellenőrizhetőek, megcáfolhatóak. Az információs társadalom paradigma alapvető változásokat jelent az oktatási rendszer, a tudásátadás és a tanulás, ismeretszerzés dimenzióiban egyaránt, ahogy Bessenyei (2007) az online környezetre utalva megjegyzi „a világhálón nagymértékű spontán tudáscsere zajlik”.

Bessenyei (2007) Jukes és Dosaj 2003-as munkáját idézve a következőképpen foglalja össze a web 2.0-át használó új generáció és az ipari társadalomban szocializálódott tanárok közötti kulturális különbséget:

2. táblázat: Tanulók és tanárok kulturális jellemzői (Forrás: Bessenyei, 2007)

\begin{tabular}{|c|c|}
\hline „Digitális bennszülött” tanulók & „Digitális bevándorló” tanárok \\
\hline $\begin{array}{l}\text { Gyorsan kívánnak információt szerezni számos } \\
\text { multimédia-forrásból }\end{array}$ & $\begin{array}{l}\text { Korlátozott számú forrásból származó információ lassú } \\
\text { es ellenőrzött átadását részesítik előnyben. }\end{array}$ \\
\hline $\begin{array}{l}\text { A párhuzamos információfeldolgozást és a több } \\
\text { feladattal való egyidejű foglalkozást (multitasking) } \\
\text { kedvelik. }\end{array}$ & $\begin{array}{l}\text { A szinguláris információfeldolgozást és az egyetlen (vagy } \\
\text { csekély számú) feladatra való koncentrálást kedvelik. }\end{array}$ \\
\hline $\begin{array}{l}\text { A szövegnél szívesebben dolgoznak kép-, hang- és } \\
\text { videoinformációkkal. }\end{array}$ & $\begin{array}{l}\text { A kép-, hang- es videoinformációkkal szemben előnyben } \\
\text { részesítik a szöveget. }\end{array}$ \\
\hline $\begin{array}{l}\text { Szívesen keresnek rá véletlenszerűen, hiperlinkek útján } \\
\text { elérhető multimediális információra. }\end{array}$ & $\begin{array}{l}\text { Lineárisan, logikusan felépített és adagokra bontott } \\
\text { információk nyújtására törekednek. }\end{array}$ \\
\hline $\begin{array}{l}\text { Kedvelik a szimultán kölcsönhatásokat, illetve a hálózati } \\
\text { kapcsolatok létesítését számos más felhasználóval. }\end{array}$ & $\begin{array}{l}\text { Azt szeretnék, ha a tanulók inkább függetlenül, mintsem } \\
\text { másokkal hálózati kapcsolatokat fenntartva, } \\
\text { kölcsönhatásban dolgoznának. }\end{array}$ \\
\hline $\begin{array}{l}\text { Legszívesebben „éppen időben” (just-in-time), vagyis az } \\
\text { utolsó pillanatban tanulnak. }\end{array}$ & $\begin{array}{l}\text { Szívesebben „minden eshetőségre felkészülve” (just-in- } \\
\text { case) tanítanak (a vizsgakövetelmények szem előtt } \\
\text { tartásával). }\end{array}$ \\
\hline Az azonnali megerősítést és azonnali jutalmat kedvelik. & $\begin{array}{l}\text { Szívesebben választják a késleltetett } \\
\text { megerősítést és jutalmazást. }\end{array}$ \\
\hline $\begin{array}{l}\text { Azt tanulják szívesebben, ami releváns, azonnal } \\
\text { hasznosítható és egyszersmind szórakoztató. }\end{array}$ & $\begin{array}{l}\text { A standardizált tesztekre való felkészítést szolgáló } \\
\text { oktatást részesítik előnyben, a tantervi irányelveknek } \\
\text { megfelelően. }\end{array}$ \\
\hline
\end{tabular}


Mint látható a fiatal generációk más minőséget képviselnek nem pusztán médiafogyasztásban, hanem abban is, ami a tanulási preferenciáikat illeti. Jenkins és munkatársai (2009) ezt a különbséget úgy írják le, mint a vadász és a gazda közötti készségek különbségét, míg a gazda tevékenységei a szinguláris készségeket igénylik, hiszen a gazdaságban a tevékenységeknek meghatározott rendje van, addig a vadász egy ingergazdag környezetben kell, hogy felkutassa és elejtse a vadat. Az oktatási rendszer hosszú idő óta gazdákat próbál képezni és nem vadászokat, ugyanakkor az infokommunikációs eszközökhöz kötődő multitasking viselkedés a vadászat készségeit erősíti. Amennyiben elfogadjuk az információs társadalom paradigma létezését azt is el kell fogadnunk, hogy van értelme annak a kulturális szocializációnak, amelynek segítségével részesei lehetünk a globális társadalomnak, így a különböző infokommunikációs technológiák, a web 2.0, a wikik, blogok, és közösségi oldalak, stb. világa és az ezekhez kapcsolódó felhasználói készségek kritikus fontosságúak.

Összességében kevés, főleg friss kutatás foglalkozott ${ }^{57}$ eddig a multitasking és a tanulás viszonyával, azon túl, hogy a kognitív rendszerre milyen terhelést jelentenek a különböző feladatok. Tapasztalataik szerint a figyelem megosztása megzavarja a memóriahasználatot, megjelenik a kognitív fáradtság és összességében a rosszabb teljesítményt nyújtanak főként azokban az esetekben, amikor az egyes információs csatornák szemantikailag eltérő adatokat szállítanak. (Vega, 2009) A felnőttek körében végzett kutatások (is) általában azt mutatják ki, hogy a párhuzamos módon történő feladatvégzés csökkenti a sebességet és a minőséget a soros feladatvégzéshez képest, ugyanakkor a mindennapi gyakorlatban jelen van. Spink és munkatársai (2007) kutatása szerint a könyvtárlátogatók kétharmada végez átfedő tevékenységeket átlagosan látogatásonként 2,5 témaváltással és közel három téma egyszerre történő kutatásával ez megfelel Spink (2004), illetve Spink és társai (2002) korábbi eredményeinek. Vega (2009) Foerde és munkatársai 2006-os munkájára utalva kifejti, hogy a multitasking közbeni tanulás és a fókuszált figyelem másfajta memóriahasználatot és így másfajta tudásáramlást eredményezhet. A felnőttek körében végzett kutatás szerint tanulás során, ha közben fókuszált figyelmet összpontosítanak, akkor a tanultak a deklaratív memóriában rögzülnek (így a tanultak jobban alkalmazható módon hívhatóak elő), míg a

\footnotetext{
${ }^{57}$ Vega (2009) Naveh-Benjamin és munkatársai (2000), Bergen és munkatársai (2005), Drew - Grimes (1987), Grimes (1991), Lang (1995), Reese (1984) munkáit említi Foehr-t (2006) idézve.
} 
multitasking közben tanultak a procedurális memóriában tárolódnak (ezeket az ismereteket nehezen tudjuk új, kreativitást és adaptív problémamegoldást kívánó helyzetekben alkalmazni, a megszokott cselekvésekben vannak inkább segítségünkre).

Lauricella és munkatársai (2009) négy éves gyerekeket és szüleiket vizsgálva megfigyelték, hogy a korosztály kétharmada szokott számítógépezni és a többség képes használni a számítógép egerét is, bár a közös számítógépezés során gyakorta jelen van a szülői segítség. A kutatók egy kísérletet terveztek, amelyben olyan számítógépes mesekönyveket (computer storybook) nézettek a gyerekekkel és szüleikkel, ahol aktív egérhasználatra volt szükség a történet továbbgörgetéséhez. A tapasztalatok szerint azok a gyerekek, akik képesek voltak az egérhasználatra ugyanúgy megértették a történetet mint, azok akiknek a szülei kezelték az egeret, pusztán annyi volt a különbség, hogy az egeret kezelő gyerekek később értek a történet végére.

A fiatalok körében tanulás terén leggyakrabban megfigyelhető párhuzamos tevékenységek az iskolai órákon, illetve a házi feladat készítés közben előforduló multitasking. Az előadások és a házi feladat írás párhuzamossága arra utalhat, hogy ezek a tevékenységek nem kötik le túlságosan a gyerekek figyelmét. A Kaiser Family Foundation naplós vizsgálatának tapasztalatai szerint számos gyerek esetében előfordult a tanulás közbeni multitasking, amely elmondásuk szerint elősegíti produktivitásukat, ellenkező esetben unatkoztak volna. (Roberts et al., 2005).

Vega (2009) beszámol olyan fiatalok körében végzett kutatások eredményéről (Schmidt - Vandewater, 2008; Schnabel, 2009), amelyek során a kutatók gyenge pozitív kapcsolatokat találtak a nagymértékű elektronikus médiahasználat és a koncentrációs problémák között, főleg a szórakoztató tartalmak esetében.

Vega (2009) beszámol egy kísérletről (Hembrooke - Gay, 2003), amelyet főiskolai hallgatók körében végeztek. A kísérlet során a hallgatók egy csoportjának engedélyezték másik csoportjának nem engedélyezték, hogy használják laptopjaikat az előadások alatt. A tapasztalatok szerint, a laptophasználó csoportba tartozók kevésbé tudták felidézni az előadásokon elhangzottakat a laptopot nem használó társaikhoz képest.

Pool és munkatársai (2003) 160 nyolcadikos tanuló házi feladatok terén nyújtott teljesítményét vizsgálták meg mediatizált és médiamentes környezetben. A kutatás megállapításai szerint amennyiben a különböző információs csatornák nem ugyanazon erőforrásokat kötik le, a szimultán feladatvégzés nem jár mindenképpen 
teljesítményveszteséggel - a fiatalok házi feladat írása közben nyújtott teljesítménye nem változott zenehallgatás vagy zenei klipek nézése alatt, ugyanakkor visszaesett szappanoperák nézése közben.

Calvert (2009) a Stanford Egyetemen tartott multitasking workshopon beszámolt egy olyan kísérletről is, melynek során középiskolások dolgozatírása közben vizsgálták a multitasking tevékenység hatását. Azt találták, hogy nem volt különbség a dolgozatok minőségében aszerint, hogy az illető élt-e a multitasking lehetőségével, vagy sem, ugyanakkor a többfeladatos feldolgozást gyakorlók átlagosan később készültek el a dolgozatukkal.

Mindez azt jelenti, hogy - felismerve a fiatal generációk eltérő tanulási, megismerési módjait - a kurrikulumok fejlesztése során elengedhetetlen a különböző médiumok fejlesztő hatására építeni. Míg az olvasás a szókincset, a képzelőerőt, vagy a kritikai gondolkodást, a vizuális elemek a vizuális feldolgozás képességét fejlesztik. Van, ahol már az intézmények is felfigyeltek ezekre a különbségekre és találtak megoldásokat arra, hogy a figyelem fókuszát hogyan irányítsák a konkrét iskolai feladatokra. Jenkins és társai (2009) számolnak be ilyen gyakorlatokról pl. a tantárgy témájában vezetett blogról, amely releváns, színes tartalmakkal tartja a témát folyamatosan a figyelem központjában; vagy olyan megoldásokról, amelyet a Manhattan-i Brearley School-nál vezettek be, ahol közvetlenül az iskola szervereiről kapják a diákok az idegennyelvi tartalmakat az iPod-jaikra. 


\section{3. (MÉDIA ÉS KOMMUNIKÁCIÓS) MULTITASKING MODELLKÍSÉRLET}

Az új médiához és fogyasztási jellegzetességekhez kapcsolódó - fentebb bemutatott narratívák és megosztottságok nem új keletűek, a többi médium esetén is jelen voltak, vannak hasonló tényezők. A (média)fogyasztói magatartást befolyásoló ismérveket Gálik (2003) Kotler és mások munkái nyomán foglalta össze. Eszerint a fogyasztó preferenciáira hatással vannak:

- a legközvetlenebb pszichológiai jellemzők (motiváció, észlelés, tanulás, gondolkodásmód és attitűdök);

- személyes jellemzők (kor és családi életciklus, foglalkozás, gazdasági körülmények, életmód, személyiség és az énkép)

- társadalmi jellemzők (referenciacsoportok, család, társadalmi szerepek és stílusok)

- kulturális jellemzők (kultúra, szubkultúra, társadalmi osztályok)

Dolgozatomban a fent bemutatottak alapján értelmezem a média és kommunikációs multitaskingot, tehát az információs társadalom ezen belül a szocializációs közegek generációs keretrendszerében, illetve a szociodemográfiai jellemzők szerint vizsgálom. Fontosnak tartom továbbá a média és kommunikációs multitasking kontextuális tényezőinek a vizsgálatát is, amit jelen esetben leginkább a multitaskingba belépő médiumokra illetve a tevékenységek jellegére korlátozódik. Utóbbival kapcsolatban vizsgálni kívánom a következő - elsősorban az infokommunikációs eszközökhöz köthető - tevékenységcsoportokat: (1) rekreáció - főleg médiafogyasztás, (2) kommunikáció főleg online és mobil kommunikáció, (3) erőforrás-bővítés - főleg az online tanulás és az infokommunikációs eszközök környezetében végzett munka. Jelen kutatás (empirikus része) ugyanakkor nem terjed ki a pszichológiai, kognitív aspektusok vizsgálatára, illetve csak érintőlegesen foglalkozik a kontextus környezeti jellemzőivel és a tevékenységtípusok társas jellegével. 
1. ábra: A média és kommunikációs multitasking keretei és kontextuális jellemzői

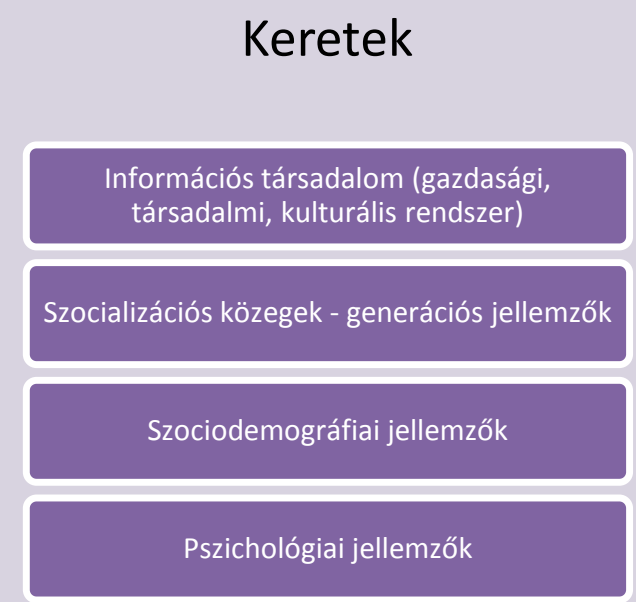

Kontextus

Tevékenység jellege (rekreációs, erőforrásbővítő és társas tevékenységek)

Médiumok, aktorok

A kontextus környezeti jellemzői (pl. helyszín)

Kognitív szempontok

A multitasking definíciójához kapcsolódóan többen (Baron, 2005; Ahlers, 2006; Kenyon és Lions, 2007; Greenfield, 2009; Ophir, 2009; Roberts és Foehr, 2009, Salvucci és munkatársai, 2009; Bannister és Remenyi, 2009; Wallis, 2010) próbálkoztak a különböző párhuzamos tevékenységek felosztásával és ez alapján valamilyen tipológia megalkotásával. A különböző felosztások a tevékenységek típusától függően, illetve a különböző közvetítő eszközök mentén tesznek különbségeket. Témánk szempontjából az egyik legfontosabb különbség ${ }^{58}$ a média és a nem média típusú multitasking. Utóbbira példa Baron (2006) „társas” és „kognitív” felosztása, ahol a kognitív multitasking azt jelenti, hogy a kognitív rendszert használjuk egy, vagy több feladat együttes végzése során, ilyen az, ha pl.: vezetés közben a térképen keressük a helyes útirányt. A társas multitasking arra utal, hogy a párhuzamosan végzett tevékenységek egy interaktív térben zajlanak, pl.: beszélgetés közben levelet írunk. Salvucci és Taatgen (2008) javaslatot tesz egy kifejezetten pszichológiai alapú kognitív multitasking modellre, amely a teljes multitasking helyzet megértésére törekszik a tényleges viselkedéstől a kognitív rendszeren keresztül az agyi folyamatokig.

A 2009-ben, a Stanford Egyetemen tartott konferencián több esetben is megfogalmazódott a média multitasking tevékenység viszonya a közösséghez. Volt, aki úgy fogalmazta ezt meg, hogy a multitaskingot gyakorlók „mindig máshol vannak” az itt

\footnotetext{
58 Jenkins és munkatársai megkülönböztetik a médiumok közötti navigáció (transmedia navigation), azaz többféle forrás mentén követni a történéseket és általában a multitasking (a környezet figyelme és a figyelem összpontosítása a szükségleteknek megfelelően) tevékenységét. (Salvucci et al., 2009)
} 
és most kereteitől eltávolodnak ${ }^{59}$. Mások ennek némileg ellentmondva azt látják, hogy ők „soha sincsenek egyedül", mert folyamatosan élvezik a mediatizált támogató közeget, az infokommunikációs eszközök közvetítette szociális teret. (Wallis, 2010)

Wallis (2010) egyéni és társas multitaskingot (social multitasking vs. solo multitasking) különböztet meg, ahol a nem virtuális közösségre utalva a közös filmnézés közbeni másokkal való SMS-ezést hozza fel példaként.

A média multitasking világában Roberts és munkatársai szerint fontos különbséget tenni a valódi médiahasználat ${ }^{60}$ (media use) és a média-elérés, médiának való kitettség (media exposure) között. Roberts és Foehr amellett érvelnek, hogy a kutatóknak újra kell gondolniuk a médiafogyasztás konceptualizációját, hogy elkülöníthetővé váljon a gyerekek valódi médiahasználata és a médiának való kitettsége ${ }^{61}$. (Roberts et al., 2005; Roberts - Foehr, 2009) Wallis (2010) összefoglaló munkájában hasonló megfontolásokból megjelenik az aktív és a passzív (vagy más kifejezéssel előredőlős, vagy hátradőlős) média multitasking kifejezése. Neuman és Pool 1986-os munkáját idézve Gálik (2003) amellett érvel, hogy a médiatermékek fogyasztása nem dichotóm (igen-nem) kategóriákban értendő, hanem folytonos szakaszonként ${ }^{62}$ az elmélyült odafigyelő fogyasztástól a háttérfogyasztásig.

Greenfield (2009) három különböző média multitasking típust különböztet meg: (1) a médiatevékenységgel kombinált „valóságos” interakciót (pl. gépelés ebéd közben), (2) több különböző médium együttes használatát (pl. SMS-ezés rádióhallgatás közben), (3) és az egy eszközhöz kötődő párhuzamos médiatevékenységet (pl. zenehallgatás az iTunes-en, e-mailezés és online kutatás végzése egy időben). Wallis (2010) szerint a

\footnotetext{
${ }^{59}$ Ahogy Sherry Turkle írja népszerű könyvében, „az internet több mint régi bor új palackokban, mostantól már mindig máshol lehetünk". (Turkle, 2011)

${ }^{60}$ A médiafogyasztás és médiahasználat fogalmait egymás szinonimájaként alkalmazom. Léteznek olyan megközelítések, amelyek megkülönböztetik a két fogalom jelentését a használathoz tudatosabb jegyeket társítva. Munkámban a médiafogyasztást és médiahasználatot tudatosnak tekintem és megkülönböztetem a kevésbé tudatos médiának való kitettségtől.

${ }^{61}$ A két fogalom közötti különbség a média multitasking miatt fontos. A médiafogyasztás a mediatizált környezetben eltöltött időt jelenti, míg a kitettség a médiumonkénti összfogyasztás idejét. Egy Roberts és munkatársai (2005) által bemutatott példa szerint: adott egy tinédzser, aki napi két órát néz televíziót, egy órát olvas és hallgat zenét egyszerre, és egy órán át játszik videojátékot, miközben szintén zenét hallgat a számítógépén. A médiának való kitettsége így összességében hat óra ( 2 óra TV+ 1 óra olvasás+ 1 óra videojáték+ 2 óra zene), míg a médiakörnyezetben eltöltött ideje négy óra ( 2 óra TV+ 1 óra olvasás és zene+ 1 óra videojáték és zene).

${ }^{62}$ A szakaszos felosztás médiatípusonként más és más, amely egyrészt technológiai sajátosságokra is visszavezethető, de függhet attól is, hogy milyen környezetben és milyen körülmények között történik (pl. nem mindegy, hogy egy áruházban hall(gat)juk a vásárlótérbe sugárzott zenét, vagy kedvenc CD-nket a számítógépünkön, stb.). A televíziózásra vonatkozóan megkülönböztethetjük a felületes, eseti nézést, vagy háttér-televíziózást a figyelmes nézéstől, illetve az odaadó, beleélő nézéstől. (Gálik - Urbán, 2008)
} 
média multitasking legalább három típusba sorolható: (1) valamilyen médium és faceto-face interakció között (2) két vagy több médium között, és (3) egyetlen médiumon belül.

A média multitasking a kontinuitás mentén is osztályozható, az egymással konkuráló tevékenységek közötti gyors váltásoktól kezdve a szekvenciális tevékenységekig, amelyek között ritkábban történik váltás. (Salvucci et al., 2009) Síklaki (2011, pp:157) szerint lényeges „különbséget tennünk az olyan multitasking között, amikor lényegében egy időben kell több feladatot végezni, és a között, amikor egy domináns feladatot időről időre megszakítunk". Ophir (2009) makro multitaskingnak nevezi azokat a tevékenységeket, amelyek pl. többféle projekt feladatainak és a feladatokhoz kapcsolódó átfedésben lévő határidők sokszor zsonglőri menedzselése során jelennek meg, míg mikro multitaskinggal utal azokra a gyorsabb tevékenységváltásokra, amelyek pl. munka - az elsődleges feladat végzése - közben érhetik az embert e-mailek, telefonhívások, háttérzene hallgatása, vagy a figyelem face-to-face megszakításai, stb. során. (Wallis, 2010)

A média multitasking típusok kötődhetnek eszközökhöz, technológiához is. Ezek alapján megkülönböztethetünk hagyományos, online, illetve online-hagyományos multitaskingot. Míg előbbi hagyományos médiumokon keresztül megy végbe (pl. rádióhallgatás és újságolvasás, vagy televízió nézés és újságolvasás párhuzamossága), az online multitasking során a párhuzamos használat digitális térben, kizárólag a számítógépen, interneten történik (különböző alkalmazások együttes futtatása, több ablak párhuzamos megnyitása). Lehetséges a kétféle forrás kombinációja is: online hagyományos multitasking. A tapasztalatok alapján az online tevékenységek közben leggyakrabban a televízió szól a háttérből, vagy a tévézés közben chat, levelezés folyik.

Bannister és Remenyi (2009) több tényezőt is figyelembe vesz, amikor megalkotja multitasking modelljét. Egyrészt megkülönbözteti a tudatos versus nem tudatos multitaskingot, előbbi részben megfelel Baron (2006) kognitív jellemzőjének azzal a különbséggel, hogy ebben az esetben azokat a tevékenységeket tekintjük nem tudatos cselekedeteknek, amelyek koncentráció nélkül is megvalósíthatók (pl. vezetés közben a kormány és a pedálkezelés automatikusan történik, míg a forgalom követése figyelmet igényel). Bannister és Remenyi a tudatos multitasking felosztásával foglalkozik és az alábbiak alapján 36 elméleti szimultán helyzetet határoz meg: tevékenységek szerint 
egy, vagy több tevékenység; kommunikáció szerint egy, vagy több kommunikáció, illetve kommunikációmentes állapot; szándék szerint szabályozott (önkéntes), illetve ellenőrizetlen (megszakítások), vagy mindkettő; széttagolt vagy nem széttagolt médiakörnyezetben. (Bannister - Remenyi, 2009)

A különböző megközelítéseket összegezve meglátásom szerint a következő szempontok tekinthetők fontosnak a multitasking tipizálásához ${ }^{63}$ :

2. ábra: A multitasking tipizálásának szempontjai

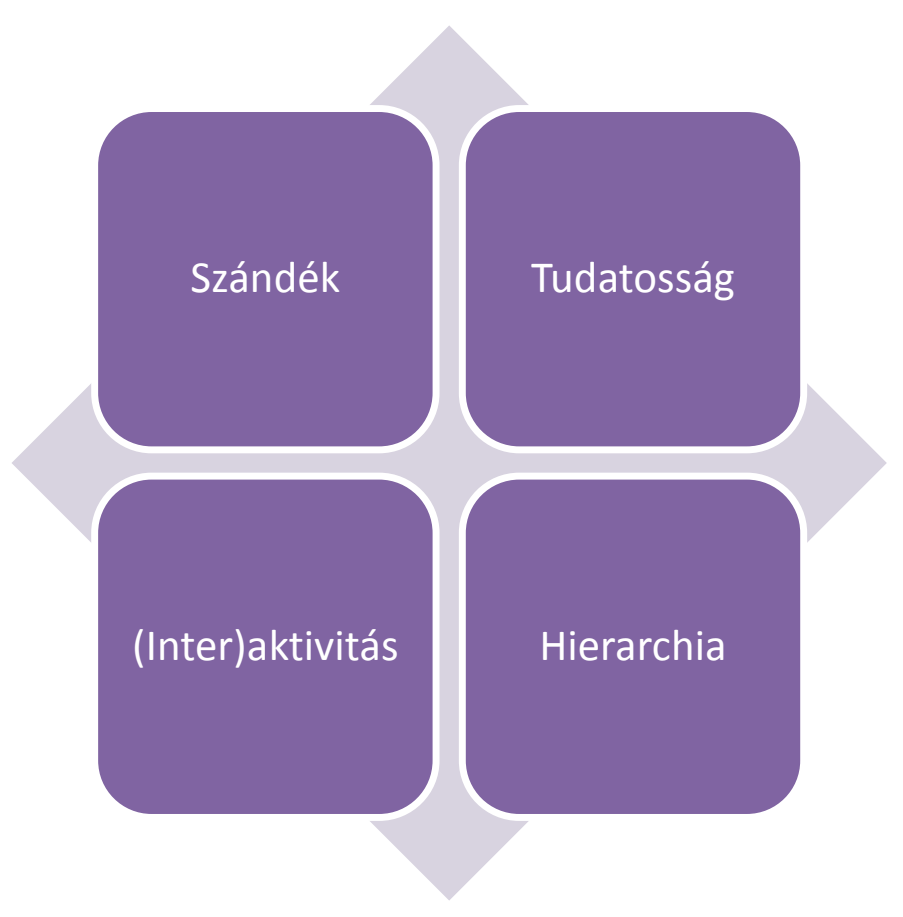

A szempontok részletesen:

1. Szándék: Az adott multitasking szituációban az egyes alkotóelemek jelenléte szándékolt (pl. online böngészés az esti film alatt), vagy nem szándékolt (média kitettség, tevékenység külső megszakítása pl. telefonhívás).

2. Tudatosság: Az adott tevékenység a kognitív rendszer leterheltségét befolyásoljae érdemben, vagy reflex-, rutinszerű-, háttértevékenységről van-e szó.

3. (Inter)aktivitás: $\mathrm{Az}$ adott tevékenységek passzív módón (figyelem és koncentráció nélkül pl. média kitettség) mennek végbe, vagy aktív cselekvés, figyelem társul hozzájuk, vagy interaktív (társas) környezetben zajlanak.

\footnotetext{
${ }^{63}$ Ezek a szempontok egy legalább 24 cellás tipológiamátrixot feltételeznek és ugyan létezhetnek olyan idáltipikus multitasking helyzetek, amelyek megfelelnek az egyes celláknak, azonban a valóságban leggyakrabban ezek valamilyen kombinációja megy végbe, ezért ezek részletes elemzésétől eltekintek.
} 
4. Hierarchia: Lényeges szempont lehet, hogy a multitasking folyamatban lévő tevékenységek megszakítások nélkül párhuzamosan zajlanak, vagy folyamatos a váltás a különböző tevékenységek között (pl. e-mail írás mellett online csevegés), vagy egyik (esetleg több) tevékenység domináns, míg a másik (vagy több másik) a háttérben zajlik (pl. zenehallgatás olvasás közben), esetleg kisebb megszakításokkal tarkítja a domináns tevékenység lefolyását.

A párhuzamos tevékenységek általánosan alkalmazható ismérvei mellett léteznek specifikusan, leginkább a média és kommunikációs multitasking területén értelmezhető tényezők ${ }^{64}$.

3. ábra: A média és kommunikációs multitasking speciális szempontjai

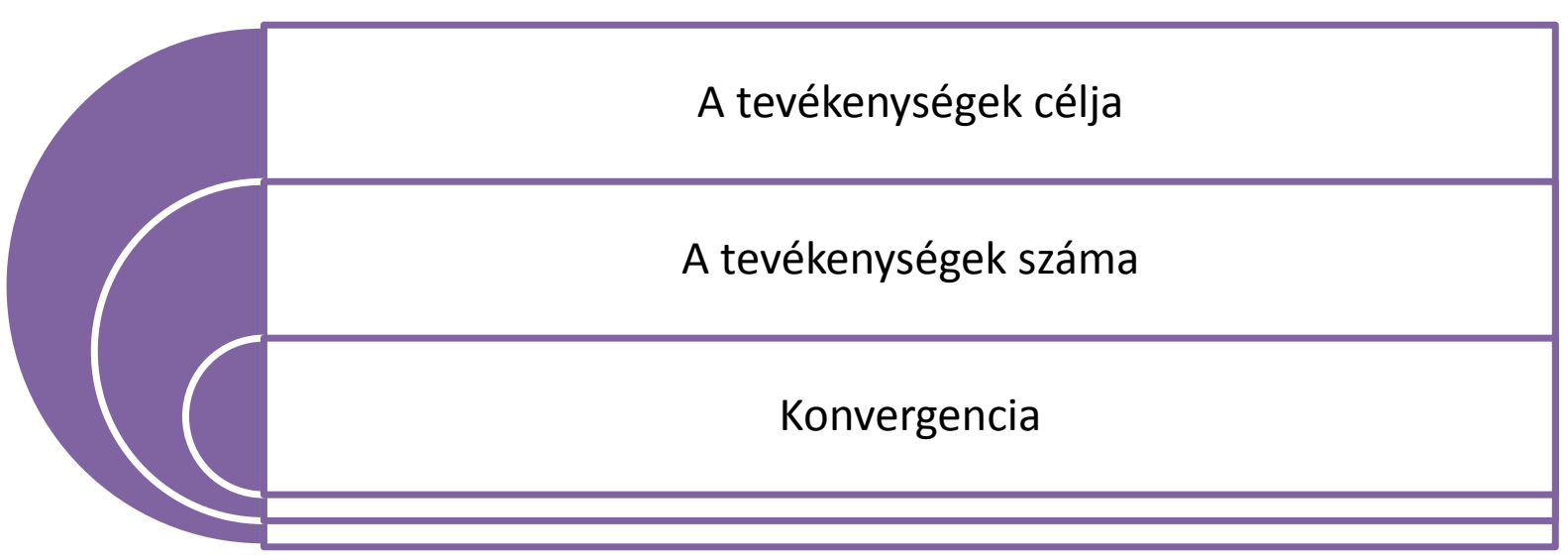

A fenti gondolatmenetet továbbvezetve egy a párhuzamos médiafogyasztással és az infokommunikációs eszközökhöz kötődő parallel digitális kommunikációval foglalkozó kutatásnak a következő ismérveket szükséges még figyelembe vennie:

- a tevékenység célját: fontos megkülönböztetni, hogy olyan tevékenységről van-e szó, aminek „tétje van”, vagy olyanról, amely inkább a kikapcsolódást szolgálja, azaz elsődlegesen rekreációs, kommunikációs vagy erőforrás-bővítés célú tevékenységről beszélünk;

\footnotetext{
64 Természetesen a nem média jellegű multitasking folyamatoknak is lehetnek egyéni jellemzőik, ilyen pl. a fentebb említett makro-mikro felosztás, amelynek médiafogyasztási vonatkozását nem tekinthetjük multitaskingnak. Elfogadva Ahlers (2006) érvelését a többforrású médiafogyasztással kapcsolatban fontos megkülönböztetni a multitaskingot, amely többféle médium egyidejű, szimultán fogyasztása és többcsatornás használatot (multichannel use), amely többféle médium használata a nap folyamán, de egymástól különböző időpontokban.
} 
- a multitaskingba bekapcsolódó média és kommunikációs tevékenységek számát: (a két véglet szerint: egy ilyen típusú tevékenység van együtt más típusú tevékenységgel, vagy több média típusú tevékenység szimultán lefolyásával van dolgunk);

- valamint a konvergenciát: a média és kommunikációs multitasking több forrásból, vagy egy forrásból (egy eszközön keresztül) megy végbe.

\subsection{KUTATÁSI KÉRDÉSEK - HIPOTÉZISEK}

A fenti szempontrendszer szerinti alapos vizsgálat megkövetelné több egészen különböző módszertan alkalmazását, amelynek azonban a korlátozott lehetőségek miatt dolgozatom nem tud teljes mértékben megfelelni. A nemzetközi kutatások bemutatásánál és a hazai empirikus eredmények prezentálásánál igyekszem ugyan megfelelni a fentieknek, azonban dacára a sokféle primer kutatásnak még sincs lehetőség a teljes spektrum lefedésére. Mindezek figyelembevételével az empirikus munkában két fő vizsgálati irányt kívánok követni65:

1. a multitasking kereteit adó szocializációs közegekkel - életkori és generációs jellemzőkkel kapcsolatos kérdéseket;

2. illetve a párhuzamos használat kontextuális elemei közül a tevékenységek jellegéhez (rekreációs, erőforrás-bővítő tevékenységek) kapcsolódó kérdéseket kívánom körüljárni.

A kétféle vizsgálati irányt a rendelkezésre álló adatok tematikája mellett egyrészt az indokolja, hogy doktori kutatásom központjában az ifjúsági korosztályok egyidejű, többcsatornás kommunikációja és médiafogyasztása áll, amelyben központi kérdés az, hogy hordoz-e az ifjúság a médiafogyasztásban is megmutatkozó generációs jellegzetességeket. Fentebb már láthattuk, hogy ez a kérdéskör igencsak foglalkoztatja a kutatókat és a következő fejezetben 66 is foglalkozom a médiafogyasztás életkorra és generációkra vonatkozó nemzetközi kutatások eredményeivel. Habár a különböző

\footnotetext{
${ }^{65}$ A saját empirikus kutatások módszertanáról szóló fejezetből kiderül, hogy a jelentősszámú vizsgálat ellenére - jórészt a kutatások eredeti célja miatt - a párhuzamos használat nem minden eleme vizsgálható, jó részük túl is lép a szociológiai megközelítésen.

66 3. fejezet: A média és kommunikációs multitasking kutatás nemzetközi eredményei.
} 
megközelítések alapján egy átfogó kép rajzolható a kérdéskörről, azonban alapvetően hiányzik annak a vizsgálata, hogy azok a médiafogyasztásban megfigyelhető különbségek, így a párhuzamos médiafogyasztás generációs, vagy életkori aspektusai erősebbek. Ami a dolgozatom másik fő tematikáját - azaz a tevékenységek jellegének vizsgálatát - illeti, elmondható, hogy korábban kevés olyan próbálkozás volt, amely a párhuzamos médiafogyasztást tevékenységtipológia mentén értelmezte volna, kutatásomban kvantitatív és kvalitatív módszerekkel egyaránt vizsgálni kívánom ezt a területet.

A két vizsgálati irányhoz két főbb kutatási kérdés és vizsgálandó hipotézis ${ }^{67}$ kapcsolódik. A kutatásom egyik főbb kérdése (RQ1), hogy főleg a fiatalok médiafogyasztásában tapasztalható jellegzetességek, így a párhuzamosság korspecifikus, vagy a digitális korszak fiataljai valóban minőségi változás hordozói, azaz korosztályos, vagy generációs hatásról van-e szó? Egyszerűbben fogalmazva a kor emelkedésével a ma „lázadóinak” viselkedése belesimul-e a korábbi generációk médiafogyasztási szövetébe, vagy sem? A kérdéshez kapcsolódó fő hipotézisem szerint:

(H1) - a médiafogyasztásban az életkori sajátosságok mellett generációs hatások is érvényesülnek, ami azt jelenti, hogy léteznek olyan, a születési évek alapján meghatározható csoportok (generációk), amelyek médiafogyasztási jellegzetességeiket az évek múlásával is megőrzik.

Az összefoglaló, vagy fő hipotézis az alábbi alárendelt, kiegészítő hipotézisek vizsgálatára épül:

(H1.1) - a médiafogyasztás mennyisége és a párhuzamos fogyasztás mértéke szerint is jelen vannak a generációs töréspontok; (H1.2) - a párhuzamos fogyasztás generációs „határai” nem esnek egybe a fogyasztás mennyiségének generációs töréspontjaival.

A kutatásom másik fő kérdése (RQ2), hogy van-e különbség a párhuzamos használatban a tevékenységek jellege szerint, a kommunikációs és médiafogyasztási multitasking tevékenységet intenzíven folytatók alkalmazzák-e és ha igen milyen gyakorisággal a

\footnotetext{
${ }^{67}$ A hipotézisek részletesebb, az empirikus eredményekhez kapcsolódó megfontolásait lásd a módszertani fejezetben (4.2. fejezet: Az elemzés és a hipotézisvizsgálat módszerei), a hipotézisek vizsgálatát a saját empirikus vizsgálatokat bemutató fejezetekben (5.2. fejezet: Generációs és életkori hatások; 5.4. fejezet: Rekreációs és erőforrás-bővítő tevékenységek).
} 
szimultán tevékenységet a kognitív rendszert jobban terhelő feladatokban, mint a munka vagy a tanulás? A kérdéshez kapcsolódó fő hipotézisem szerint:

(H2) - a párhuzamosság mértékének fontos magyarázója a tevékenység jellege:

a különböző típusú tevékenységekhez nem azonos intenzitású multitasking társul.

Az összefoglaló, vagy fő hipotézis az alábbi alárendelt, kiegészítő hipotézisek vizsgálatára épül:

(H2.1) - a rekreációs (média és kommunikációs) tevékenységekben, jelentősebb szerepet kap a multitasking, mint az erőforrás-bővítésben (munka, tanulás);

(H2.2) - a különböző tevékenységek során megfigyelhető multitasking tevékenységek a legtöbbször nem spontán alakulnak ki, hanem tervezettek, tudatosak, az egyén stratégiájától függnek. 


\section{A MÉDiA ÉS KOMMUNiKÁCIÓS MULTITASKING KUTATÁS NEMZETKÖZI EREDMÉNYEI}

\subsection{NEMZETKÖZI HOZZÁFÉRÉSI ÉS HASZNÁLATI STATISZTIKÁK}

Az információs társadalom kiterjedésével alapvetően megváltoztak a médiafogyasztási és a kommunikációs szokásaink. A technológiai fejlődés kínálta lehetőségek a rövid idő alatt beépültek a mindennapjainkba. Az elmúlt évtized globális változásait szemlélve megállapíthatjuk, hogy pl. az internethasználók száma megötszöröződött és napjainkban több mint 2,5 milliárd ember internetezik világszerte. Az International Telecommunication Union adatai szerint a fejlett országokban a népesség háromnegyede (76\%), míg a fejlődő régiókban valamivel több, mint negyede (26\%) internetezik.

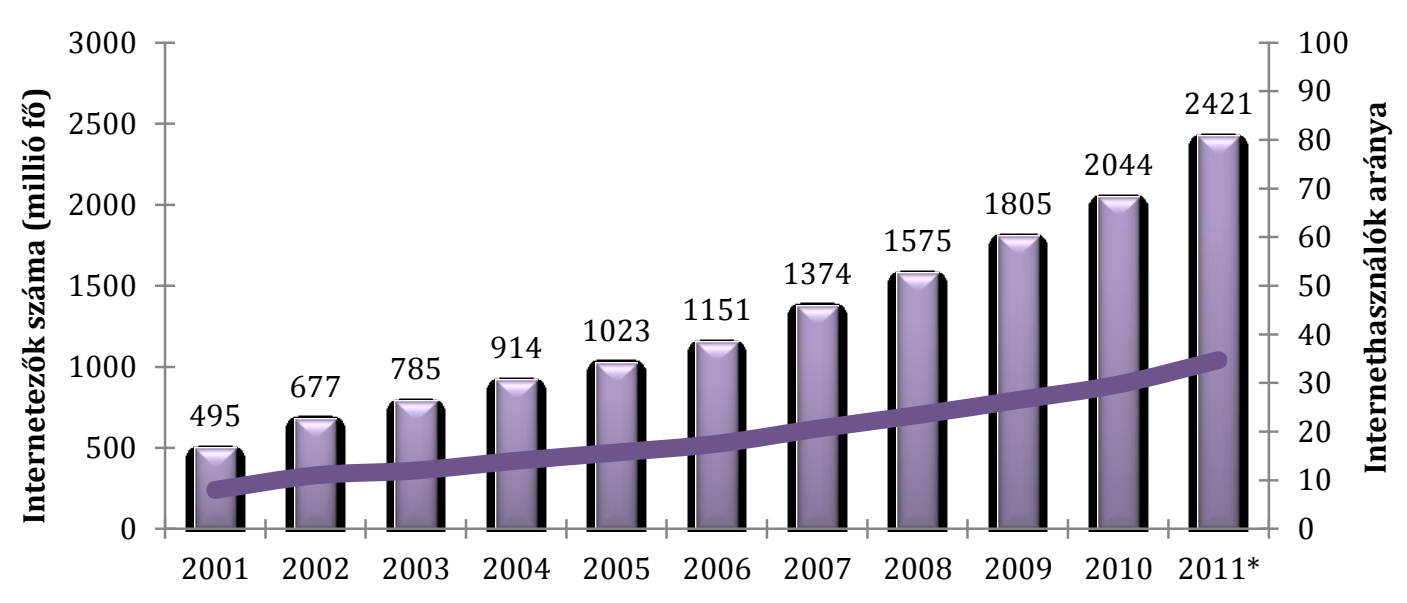

Az internethasználók arányának növekedésénél is jelentősebb növekedési potenciált produkált a mobiltelefónia. Az elmúlt évtizedre visszatekintve a 100 főre eső 15 mobiltelefon-előfizetés 87-re növekedett. A fejlett országokban, köztük hazánkban is már több éve átlépte a 100 százalékos penetrációt a mobiltelefon-előfizetések száma. 


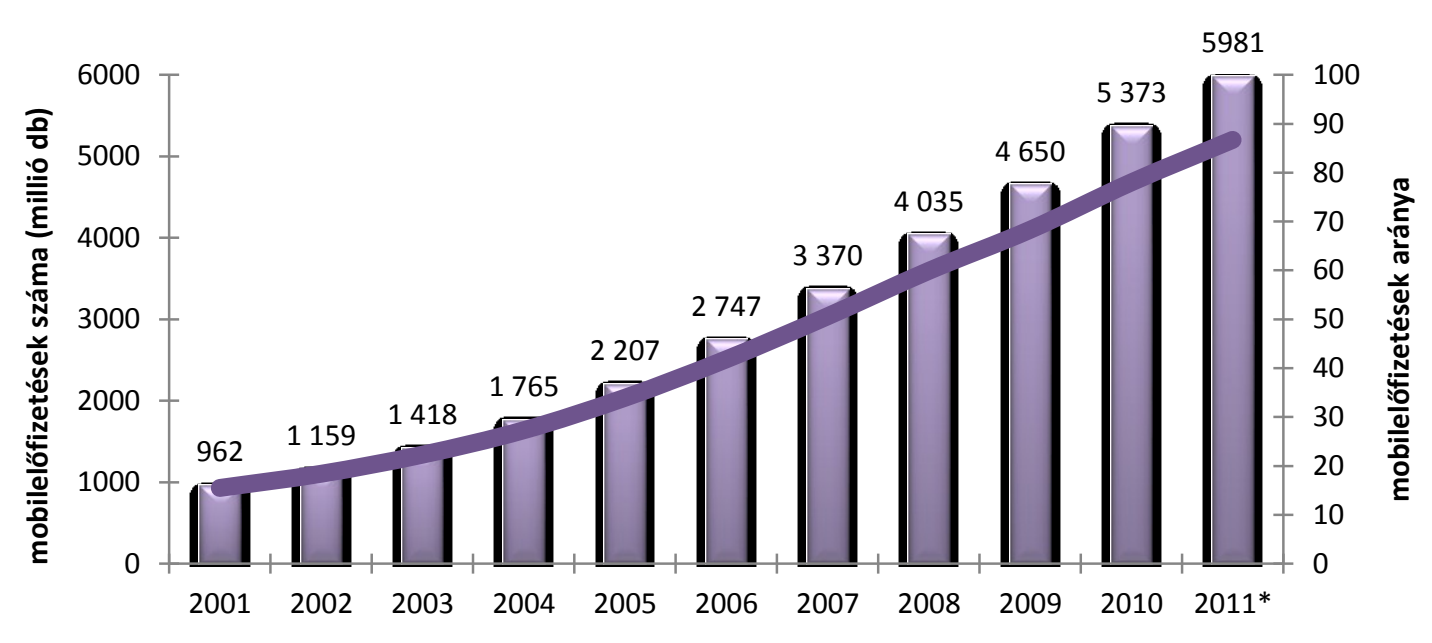

Az Európai Unió országainak legfrissebb statisztikái alapján elmondható, hogy a háztartások szinte mindegyikében megtalálható a televízió (97\%) és a mobiltelefon (89\%), míg a vezetékes telefon már csak négyből három háztartásban van jelen. A számítógép- és ineternet-hozzáférést tekintve is meglehetősen magas arányokat találunk, gyakorlatilag háromból két háztartásban megtalálható a számítógép és az internet.

6. ábra: Háztartások felszereltsége (Forrás: Special Eurobarometer 381, 2012)

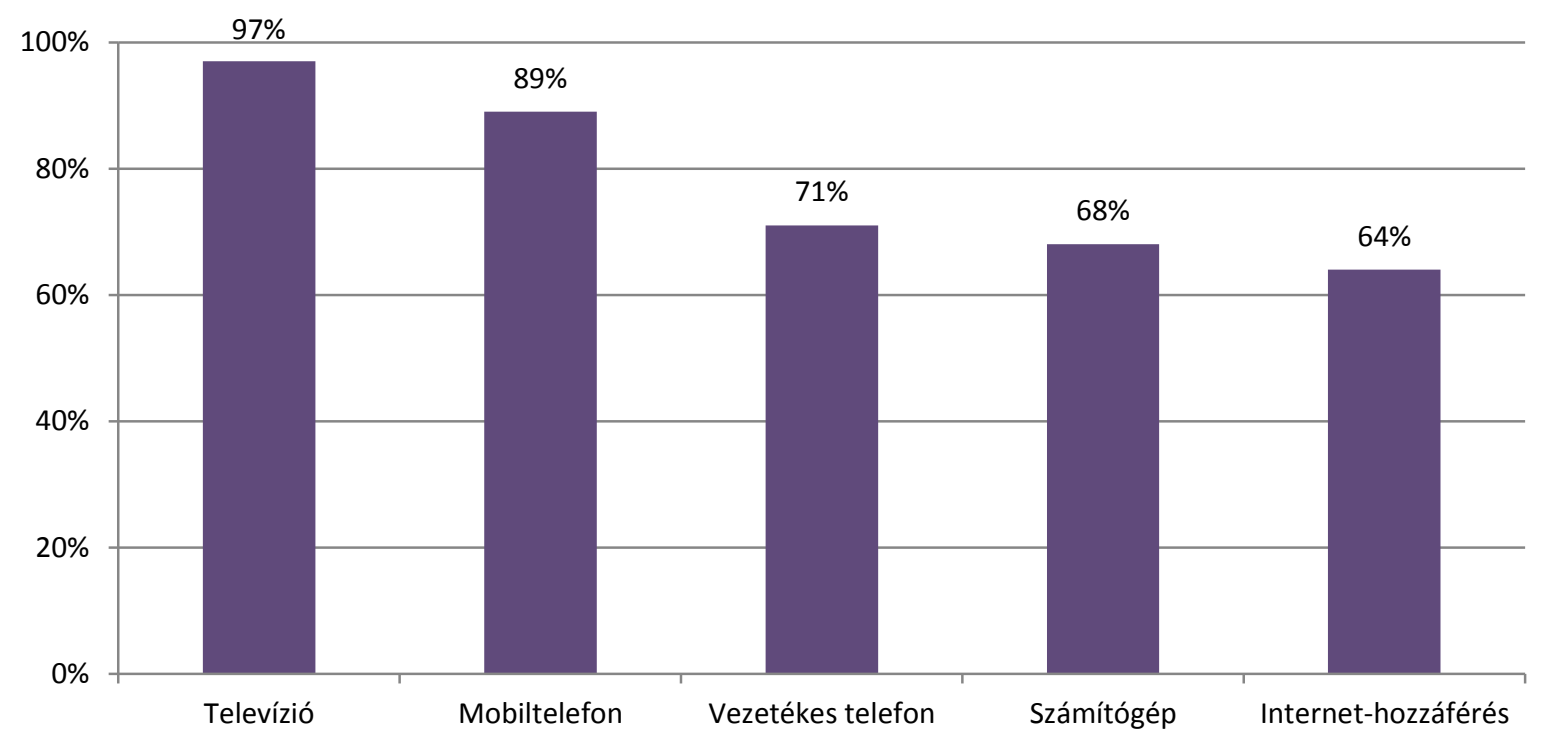




\section{2. ÁTALAKULÓ MÉDIAFOGYASZTÁSI ÉS KOMMUNIKÁCIÓS SZOKÁSOK}

A globális statisztikák által jelzett erőteljes infokommunikációs fejlődés mellett a médiafogyasztás belső szerkezete is alapvetően megváltozott. Új fogyasztási stílusok körvonalazódtak, az elérhető szolgáltatások szaporodásával egyre összetettebb fogyasztói csoportok alakultak ki és megjelent a médiának kevesebb figyelmet szentelő háttérfogyasztás.

Robinson és Martin (2009) megállapítja, hogy az Egyesült Államokban rádióhallgatás, mint elsődleges tevékenység aránya a napi elfoglaltságok között 1965 óta csökkenőben van, bár a rádiózás látványos megújuláson ment keresztül amint újraformálta magát másodlagos tevékenységként (különösképpen vezetés közben). Az olvasás (könyv, print média) halála nem következett be a televízió térnyerésével, ugyanakkor az újságok olvasásában a csökkenés látványos (átlagosan két órával kevesebb hetente), míg a könyvek valamelyest nagyobb szerepet játszanak. A televízió és videotartalmakkal töltött idő átlagosan heti öt órával növekedett meg az 1965-2005 közötti időszakban. A tévénézésnek, mint másodlagos tevékenységnek megfigyelésével több, mint harminc százalékkal emelkedik a tévénézés részesedése a napi időmérlegből, de ez a növekedés más tevékenységek esetében is tapasztalható68.

7. ábra: Televízió és egyéb szabadidős elfoglaltságok trendjei az USA-ban (Forrás: Robinson - Martin, 2009)
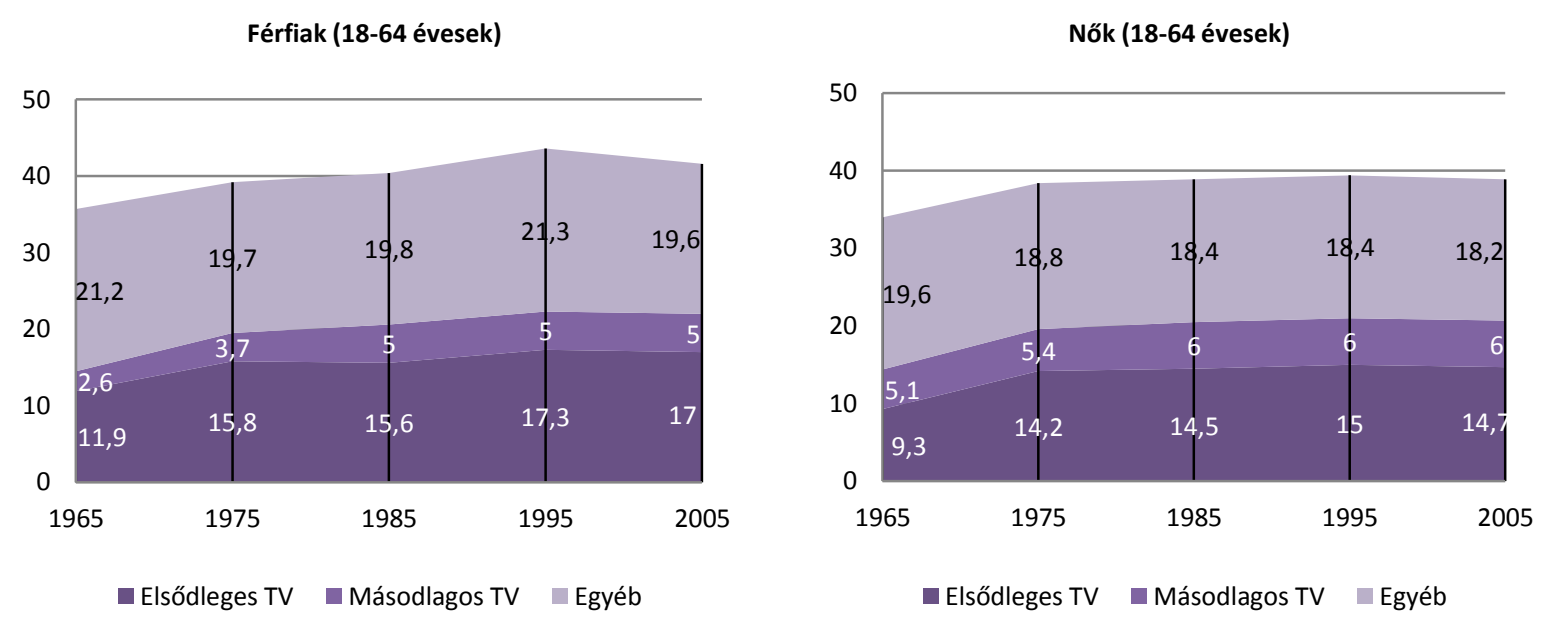

\footnotetext{
${ }^{68}$ Főleg a házimunka és a gyereknevelés területén figyelhető meg, holott fóleg a házimunka (a nők esetében 12 órával kevesebb hetente a férfiak esetében 4 órával több) összességévben csökkenést mutat a vizsgált időszakban.
} 
Felmerül a tévére fordított figyelem természetének kérdése. A tévénézésről szóló irodalom szerint a nézők fel tudják dolgozni a televíziós tartalmakat teljes figyelmük koncentrálása nélkül is. Számos friss kutatás és a figyelemhiányos rendellenességekhez kapcsolódó újabb orvosi feltételezések felvetik a kérdést, hogy az efféle tünetek hátterében mennyiben állhat a kevéssé figyelemigényes televíziós programok megjelenése. A tévénézésre fordított idő növekedésének számos lehetséges társadalmi következményei között szerepel a multitasking, az elhízás, a széttöredezett életstílusok és a homogenizálódott nemzeti kultúrák arányának növekedése, illetve a figyelem kiterjedése és a lokális kulturális élet visszaesése. (Robinson - Martin, 2009)

Az egyik legfrissebb kutatás szerint a napi átlagos médiával töltött idő 11 és fél óra az Egyesült Államok felnőtt populációjára vonatkoztatva, amelyből a legnagyobb részt (4 és fél órát) a televízió, és az internet (2 és fél órát) tölt ki. Dolliver és munkatársai (2012) megállapítják, hogy amennyiben az ember nem alszik jó eséllyel médiafogyasztási tevékenységet (is) folytat, a médiafogyasztásba integrálódó új médiaszolgáltatások csak részben veszik át a régiek helyét, gyakorta a régiek mellé rendeződnek, növelve a tényleges fogyasztás mellett a médiának való kitettséget.

8. ábra: Médiafogyasztás mennyisége egy átlagos napon (óra:perc, a multitaskingot nem tartalmazza) (Forrás:

Dolliver, 2012)

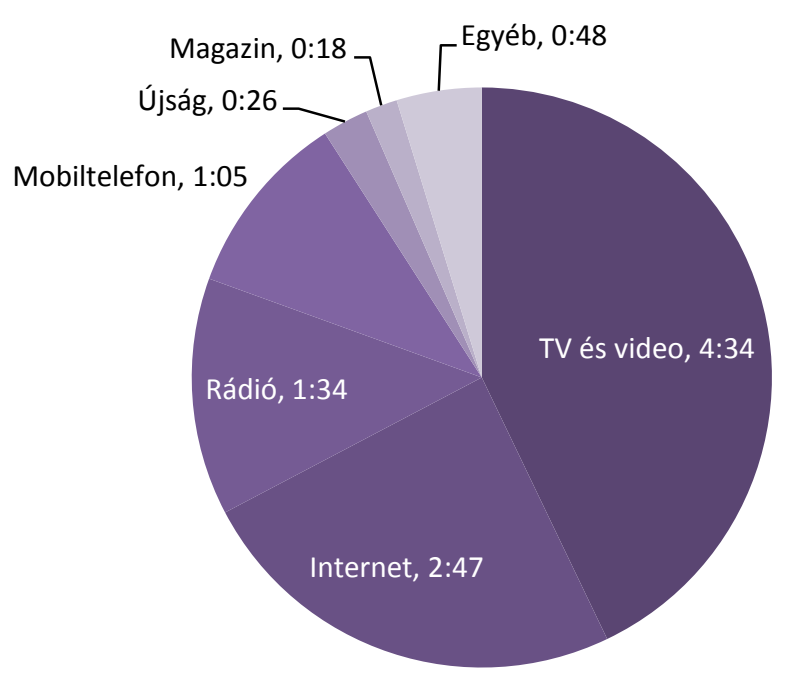

Az új technológiai megoldásokat a fiatalabb korcsoportba tartozók nagyobb valószínűséggel próbálják ki, az új eszközökhöz kapcsolódó új fogyasztási szokások is a fiatalabb korcsoportokban jelennek meg tömegesen. Egy az Egyesült Királyságban 
készült felmérés szerint a 16-24 évesek jóval nagyobb arányban és nagyobb intenzitással használják az olyan eszközöket, mint az mp3-lejátszó, az internet, vagy a mobiltelefon, mint a felnőtt társadalom tagjai.

3. táblázat: A 16-24 évesek és a felnőtt társadalom jellemzői (UK) (Forrás: Hulme, 2009)

\begin{tabular}{lcc}
\hline & $\begin{array}{c}\mathbf{1 6 - 2 4} \\
\text { évesek }\end{array}$ & $\begin{array}{c}\mathbf{1 8 +} \\
\text { társadalom }\end{array}$ \\
\hline Digitális televízióval ellátott háztartásban él & $87 \%$ & $82 \%$ \\
Van internet-hozzáférése & $71 \%$ & $62 \%$ \\
Rendszeresen használ mobiltelefont & $95 \%$ & $77 \%$ \\
Használ mp3-lejátszót & $61 \%$ & $25 \%$ \\
Használja az internetet tanulás, vagy munka céljából & $60 \%$ & $48 \%$ \\
$\begin{array}{l}\text { Használja az internetet közösségi célból, vagy szoftverek letöltésére, honlap- } \\
\text { fenntartásra }\end{array}$ & $55 \%$ & $22 \%$ \\
\hline Internethasználat mennyisége hetente & 14.7 óra & 12.1 óra \\
\hline
\end{tabular}

Az új technológiai megoldásokhoz kapcsolódó felhasználói szokások és attitűdök feltérképezése során felfigyelhetünk arra, hogy az egyidejű használat tekinthető az egyik legáltalánosabb tulajdonságnak, ami a 16-24 éveseket illeti. Tízből kilencen a megkérdezett fiatalok közül azt állították, hogy gyakran használnak egyszerre különböző technológiákat, az új technológiai megoldásokban nem ellenséget látnak, élvezik és igénylik, az életük részének érzik ezeket.

9. ábra: Az új technológiákhoz kapcsolódó attitűdök (UK) (Forrás: Hulme, 2009)

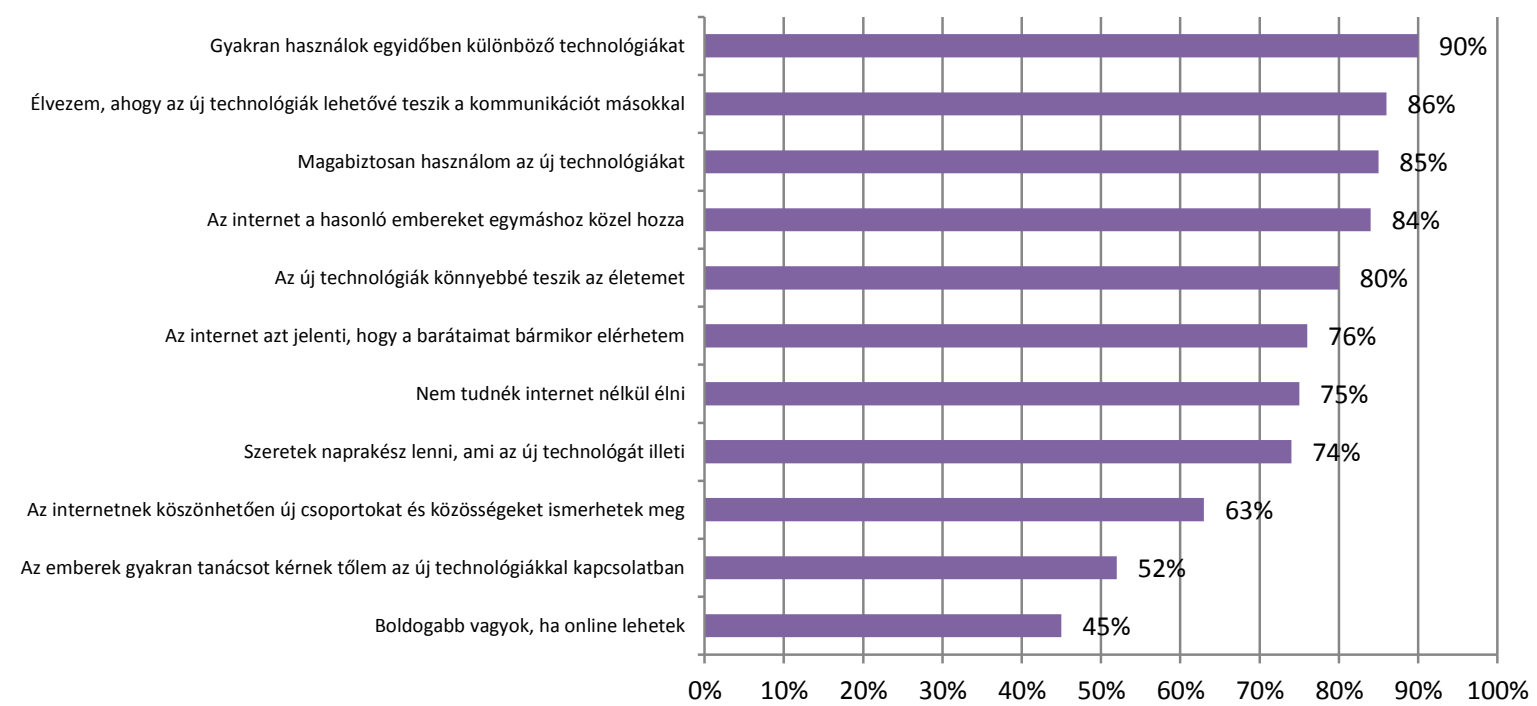


Dolliver (2012) 2008 és 2011 közötti idősoros médiafogyasztási adatokon dolgozva megállapítja, hogy a (média) multitasking teljességgel köznapi viselkedéssé vált napjainkra az Egyesült Államok felnőtt társadalmára vonatkoztatva.

Egy másik friss amerikai kutatás is azt bizonyítja, hogy nemcsak a legfiatalabbak körében jellemző a párhuzamos fogyasztás, hanem a teljes népesség esetén is jelen van. A Nielsen friss adatai szerint a népesség hattizede (58-59\%) szokta az internetet és a televíziót egyszerre figyelemmel kísérni. A párhuzamos fogyasztás mértéke emelkedik, 2009 végén 3,5 óra volt. Egyes becslések szerint körülbelül a médiahasználat 25 százaléka multitasking (overlapping) módon történik (Stevenson, 2004). (Ahlers, 2006)

4. táblázat: A Multitasking az USA-ban (Forrás: Lawler, 2010)

\begin{tabular}{lcc}
\hline & 2008. december & 2009. december \\
\hline Együttes TV-nézés és internethasználat aránya & $58 \%$ & $59 \%$ \\
Együttes TV-nézés és internethasználat ideje & 2,6 óra & 3,5 óra \\
\hline
\end{tabular}

A többképernyős fogyasztást (multi-screening) vizsgáló kutatásokból kiderül, hogy komoly szerepe van a rendelkezésre álló eszközöknek a médiafogyasztás alakulásában. Az Interactive Advertising Bureau (IAB) nemzetközi reklámszervezet kutatása szerint minél több eszköz (képernyő) áll rendelkezésre annál valószínűbb a párhuzamos használat. Míg a csak televízióval és számítógéppel bíró fogyasztók hattizede (63\%) foglalkozik valószínúleg a számítógépével is tévézés közben, addig ez az okostelefonnal és tablettel is rendelkezők közel nyolctizedére (77\%) igaz ugyanez. 


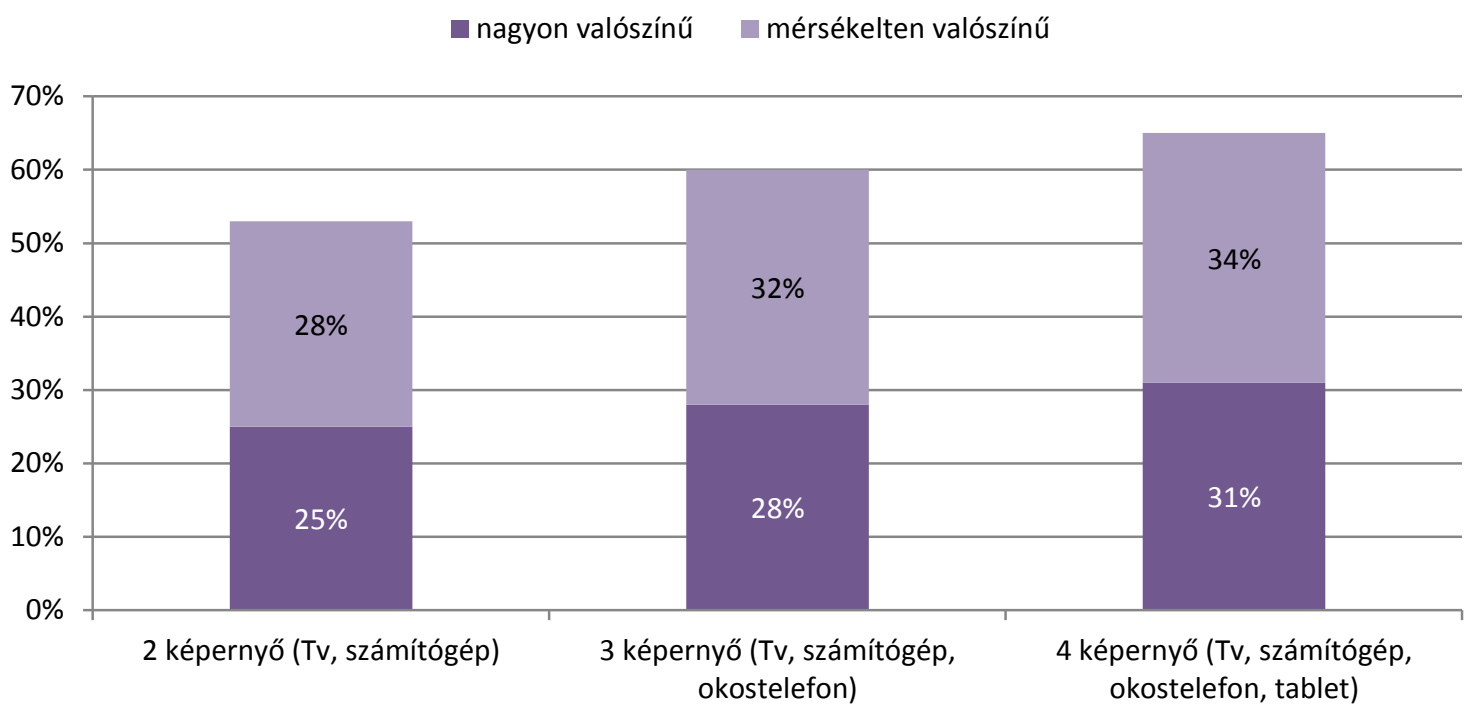

A médiatulajdonosok, hirdetők és reklámszakemberek számára kulcsfontosságú a kívánt üzenetek eljuttatása, amiben a multitasking új kihívást, de egyben lehetőséget is jelent. Az IAB kutatása szerint úgy tűnik, hogy a média multitasking előnyös is lehet a televízióban hirdetők számára, ugyanis a fogyasztók hajlamosak a televízióban látottakkal kapcsolatban online tevékenységet is végezni. Ezek a tevékenységek jellemzően valamilyen a televízióban látottakhoz kapcsolódó információs igény kielégítésére szolgálnak, vagy interaktív részvételt jelentenek (pl. tehetségkutatós szavazás), esetleg konkrét vásárlást eredményeznek. Ebben az esetben is fontos tényezőnek bizonyul az, hogy hány képernyőhöz fér hozzá az ember, az eszközök számának emelkedésével nő a bevonódás valószínűsége. 
11. ábra: Mobileszköz használata a televízióban látottak hatására (Forrás: IAB, 2012)

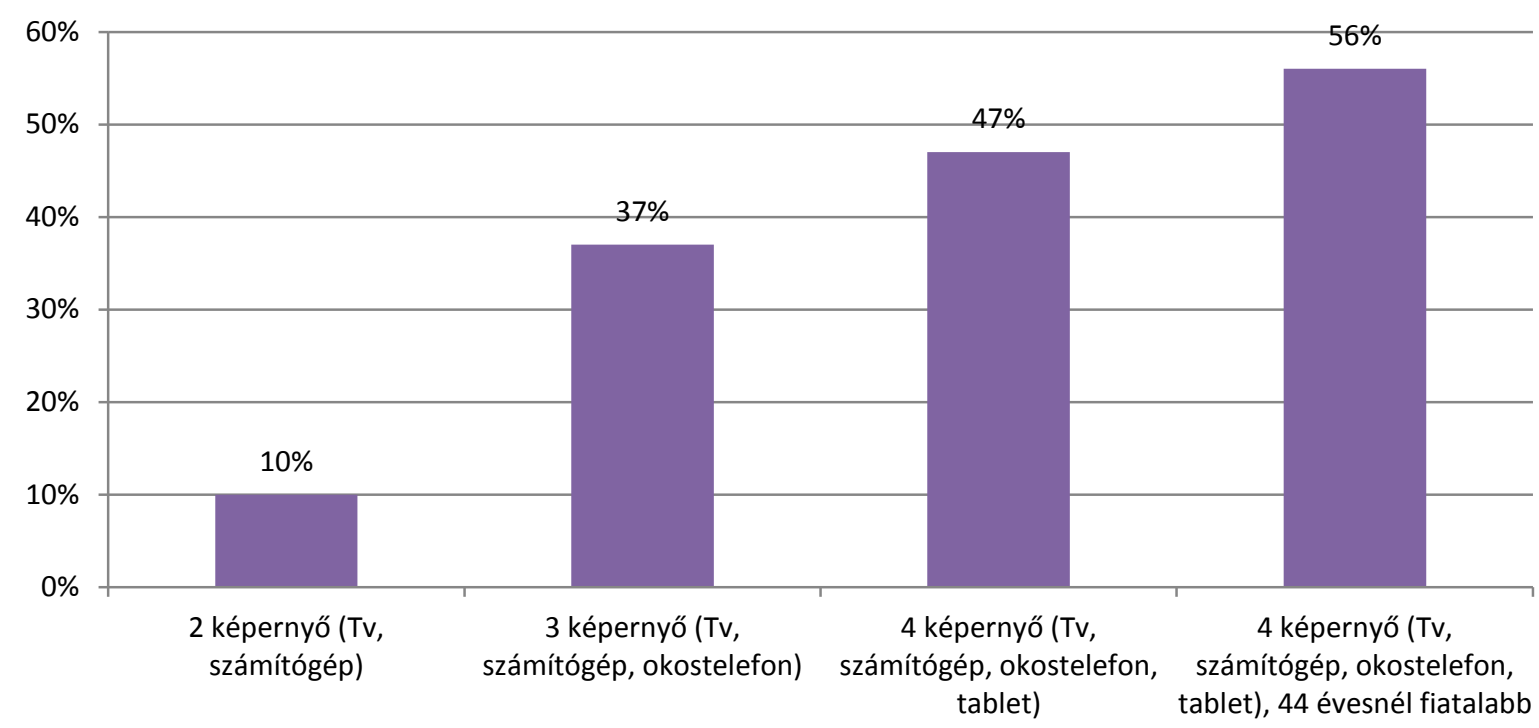

Az IAB kutatásából kiderül, hogy a műsortípusok szerint különböző mértékű az online bekapcsolódás. A leginkább ösztönző műsorok az egész estés filmek és a valóságshow típusú adások, amennyiben vásárlással kapcsolatos tevékenységekről beszélünk. Amennyiben nem vásárlásról van szó, hanem egyéb tevékenységről a valóságshow mellett megjelennek a különböző élő show műsorok (American Idol, X Factor, Dancing with the Stars), vélhetően az interaktív bekapcsolódási lehetőség (szavazás) miatt, valamint a sportműsorok, vélhetően az online sportfogadás lehetősége miatt.

Az IAB kutatása arra is rámutat, hogy a televíziózás alatt sokféle eszközt használók márka felidézési képessége is jobb, mint azoké, akik kevesebb eszközt használnak. A „négy képernyős” csoport több mint fele (53\%) meg tudta mondani, hogy a kedvenc műsorában milyen márkák hirdetnek, míg a televízió mellett csak számítógépet használók négytizede (42\%) volt ugyanerre képes. 
12. ábra: A kedvenc műsorral kapcsolatos márka visszaidézésének képessége (Forrás: IAB, 2012)

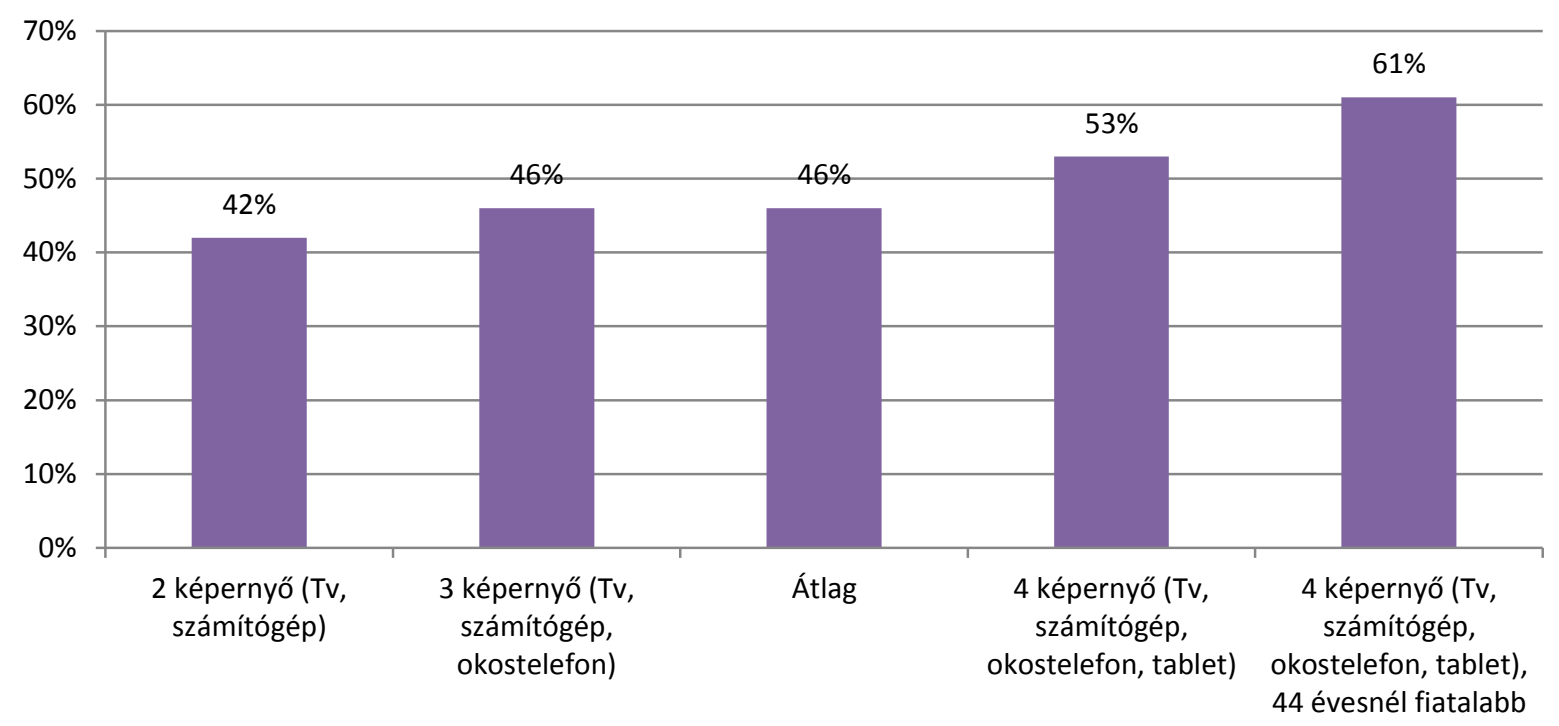




\subsection{MÉDIA ÉS KOMMUNIKÁCIÓS MULTITASKING SAJÁTOSSÁGAI}

A nemzetközi kutatások azt mutatják, hogy a multitasking általánosan jellemző médiafogyasztási stílus napjainkban, elsősorban a fiatal korosztályokban. Egy a multitasking és a generációk kapcsolatát bemutató kutatás szerint, a vizsgált legfeljebb 66 médiatevékenység kombinációjából a Baby boom generációjában (a vizsgálatban az 1946-1964 között születettek) átlagosan 23, az X generációban (a vizsgálatban az 19651978 között születettek) 32, míg a net generációban (a vizsgálatban az 1978 után születettek) 38. (Carrier et al., 2009)

Az egyes tevékenységek szekvenciális sorrendje helyett gyakori, hogy valaki egyszerre több tevékenységet végez, vagy több médiumot fogyaszt. A multitasking jelensége és az általa történő figyelemmegosztás szignifikáns hatással van a fiatalok gondolkodására, tanulására, szocializálódására, világlátására. (Vega, 2009)

Az amerikai tinédzserről az a tipikus kép alakult ki, hogy ül a szobájában és miközben a számítógépén a házi feladatát készíti más média és kommunikációs tevékenységet is folytat. A megnyitott szövegszerkesztő és az internet egyik keresőszolgáltatása a konkrét iskolai feladattal kapcsolatos felhasználást sejtet, ugyanakkor miközben ír, szörföl a neten, barátaival cseveg egy másik ablakban az iskolai eseményekről, vagy épp ellenkezőleg mindenféle másról. És mindeközben a háttérben szól a tévé, vagy fejhallgatón keresztül az iPod-ról szól a zene. (Vandewater - Lee, 2009)

Roberts és Foehr (2008) hivatkozik egy 1999-es kutatásra, amelynek során az amerikai, 2-7 év közötti gyerekek szüleit kérdezték, akik átlagosan napi 3 óra 30 perc médiának való kitettségről és 2 óra 56 perc médiahasználatról számoltak be gyerekeiket tekintve. A 8-18 évesek 6 óra 45 perc médiának való kitettséget 5 óra 40 perc médiahasználat során értek el, tehát a médiahasználat 17 százaléka során volt jelen a média multitasking. 2004-ben a 8-18 évesek átlagosan napi 7 óra 50 perc elektronikus médiának való kitettségről számoltak be 5 óra 48 perc médiahasználat mellett, tehát a médiahasználatuk 25 százaléka során két vagy több médiumnak voltak kitéve. Látható, hogy míg a médiahasználat ideje alig változott (a médiahasználat összesített időtartama nem változott, és nem igazán állítható, hogy bármely korábbi médium - például a televízió - használata visszaesett volna), addig a médiának való kitettség sokat 
emelkedett öt év alatt, amely szinte kizárólag a szimultán médiahasználatnak köszönhető.

5. táblázat: A médiafogyasztás és -kitettség változása 1999-2004 (Forrás: Roberts - Foehr, 2008)

\begin{tabular}{lccccccc}
\hline & Televízió & Video és mozi & Audio & Videojáték & Számítógép & Teljes kitettség & Teljes használat \\
\hline $\mathbf{1 9 9 9}$ & $3: 04$ & $1: 11$ & $1: 44$ & $0: 49$ & $1: 02$ & $7: 50$ & $5: 48$ \\
$\mathbf{2 0 0 4}$ & $3: 05$ & $0: 59$ & $1: 48$ & $0: 26$ & $0: 27$ & $6: 45$ & $5: 40$ \\
\hline
\end{tabular}

Napjainkban az amerikai 8 és 18 év közötti fiatalok nagyjából ugyanannyi időt töltenek a médiafogyasztással, mint a digitális eszközök elterjedése előtt (közel hét órát naponta), azonban a mennyiségileg mégis körülbelül napi két órával több médiatartalmat fogyasztanak (Roberts et al., 2005). Foehr (2006) az Amerikai Egyesült Államokban készült kutatása szerint a 8-18 éves korosztálynak alig ötöde állítja csak magáról, hogy nem fogyaszt párhuzamosan különböző médiaszolgáltatásokat, a többiek multitaskingot gyakorlónak tekinthetők ${ }^{69}$.

6. táblázat: A 12-18 évesek multitasking szokásai az USA-ban (Forrás: Foehr, 2006)

\begin{tabular}{lcccc}
\hline & Legtöbbször & Gyakran & Keveset & Soha \\
\hline Fogyaszt más médiát olvasás közben & $28 \%$ & $30 \%$ & $26 \%$ & $16 \%$ \\
\hline Fogyaszt más médiát TV nézés közben & $24 \%$ & $29 \%$ & $28 \%$ & $19 \%$ \\
\hline Fogyaszt más médiát zenehallgatás közben & $33 \%$ & $30 \%$ & $25 \%$ & $12 \%$ \\
\hline Fogyaszt más médiát számítógépezés közben & $33 \%$ & $29 \%$ & $23 \%$ & $14 \%$ \\
\hline Többféle tevékenységet végez a számítógépen & $39 \%$ & $25 \%$ & $19 \%$ & $14 \%$ \\
\hline
\end{tabular}

Az eredményekből az látszik, hogy a legkevésbé a televízió nézés és az újságolvasás közben fogyaszt más médiát a vizsgált korosztály, ami nem meglepő, hisz olyan médiumokról van szó, amelyek lekötik a figyelmet. A televízió esetében fontos tényező lehet, a készülék lakáson belüli elhelyezkedése, vagyis ha képes is egy gyermek tévénézés közben például számítógépezni, ezt mégsem teheti meg, hiszen a számítógép és a televízió nem feltétlenül ugyanabban a helyiségben található.

Magid és munkatársai (2006) megfigyelték, hogy az amerikai tinédzserek és huszonévesek a tévéhíradók nézése közben multitasking tevékenységet végeznek:

\footnotetext{
${ }^{69}$ Ezt erősíti Pendleton (2004) állítása is, miszerint az amerikai tinédzserek 80 százaléka használ egynél több médiumot egyszerre. Egy másik kutatás szerint (Pan, 2004) a megkérdezettek 70 százaléka használ szimultán módon legalább két médiumot (Hundley - Shyles, 2010)
} 
interneteznek vagy mobil készülékeket használnak, például hordozható játékkonzolokat vagy vezeték nélküli eszközöket. (Kaufhold, 2010) Egy másik amerikai kutatás azt bizonyítja, hogy nemcsak a legfiatalabbak körében jellemző a párhuzamos fogyasztás, hanem a teljes (internetező) népesség körében is. Egy online kutatás résztvevőinek mindössze 16 százaléka állította, hogy nem fogyaszt szimultán különböző médiumokat. (Pilotta et al, 2003).

Roberts és Foehr (2008) egyetértve Victoria Rideout-tal azt állítják, hogy a médiafogyasztással töltött idő már elérte csúcsát, ugyanakkor az új médiatípusoknak köszönhetően a médiának való kitettség folyamatosan emelkedik, a multitasking egyre inkább terjed és aránya egyre nő az amerikai fiatalok körében. A médiának való kitettség mennyisége erősen összefügg a szimultán médiafogyasztással, azon fiatalok, akik több kitettségről számolnak be, hajlamosabbak a média multitaskingra. A 7-12. osztályosokat enyhe, mérsékelt és súlyos multitasker csoportokba sorolva megfigyelhető, hogy a súlyos multitaskerek jellemzően az egyes médiumokat is gyakrabban használják. A sokat tévézők (több mint napi öt óra tévézés) negyede, míg a legfeljebb napi egy órát tévézők csupán tizede került a súlyos multitasker csoportba. A számítógép előtt eltöltött időt tekintve hasonló megállapítást lehet tenni a sok időt számítógépezők harmada, míg a keveset tizede súlyos multitasker.

A párhuzamos fogyasztás növekedésével magyarázható a televíziózásra fordított idő változatlansága - a gyerekek ugyanis a tévével egy időben más médiumot is használnak. E trend fő mozgatórugója a számítógép (a szerzők media-multitasking station-nek nevezik). De emellett más platformok is követik az igényeket és képesek többféle szolgáltatást is nyújtani (például a mobilkészülékeken lehet internetezni, tévézni és rádiózni is). Az átfedő fogyasztás magas gyakorisága és az új média-technológiák elburjánzása miatt egyre bonyolultabb a média-használat mérése: a hagyományos időmérleg-vizsgálatok nem arra vannak tervezve, hogy kettő, három vagy akár több egyidejű tevékenységet is felmérjenek. Roberts és Foehr amellett érvelnek, hogy az elemzőknek újra kell gondolniuk a médiának való kitettség konceptualizációját, hogy pontosabban megragadhatóvá váljon a gyerekek médiahasználata és a médiának való kitettsége. (Roberts - Foehr, 2008)

A multitasking világviszonylatban tapasztalható jelenség. Az nVision (2007) kutatásában 14 európai országban - köztük Magyarországon - mérték, hogy az internet használat 
közben mennyire jellemző a rádióhallgatás, illetve a televízió nézés. Az adatok meglepően nagy egyezőséget mutatnak, ráadásul majdnem mindenhol a tévézés inkább jellemző az internetezés közben, mint a rádiózás (valószínűleg nem függetlenül attól, hogy internetezés közben a felhasználók gyakran a számítógépen keresztül hallgatnak zenét). Az Ofcom (2007) az Egyesült Királyságban készült kutatása szerint az 5-15 évesek 59 százaléka fogyaszt más médiumokat tévénézés közben, de a korosztályon belül nagyok a különbségek. Az 5-7 évesek között mindössze 32 százalék ez az arány, nyilvánvalóan ebben az életkorban még koncentrációs problémákba ütközik a multitasking. A 8-11 évesek körében az arány már 57 százalékra nő, a 12-15 éves korosztályban pedig már kimagaslóan magas, 82 százalékos értéket mértek.

13. ábra: Televíziózást gyakran vagy néha kísérő egyéb elfoglaltságok (UK) (Forrás: Ofcom, 2007)

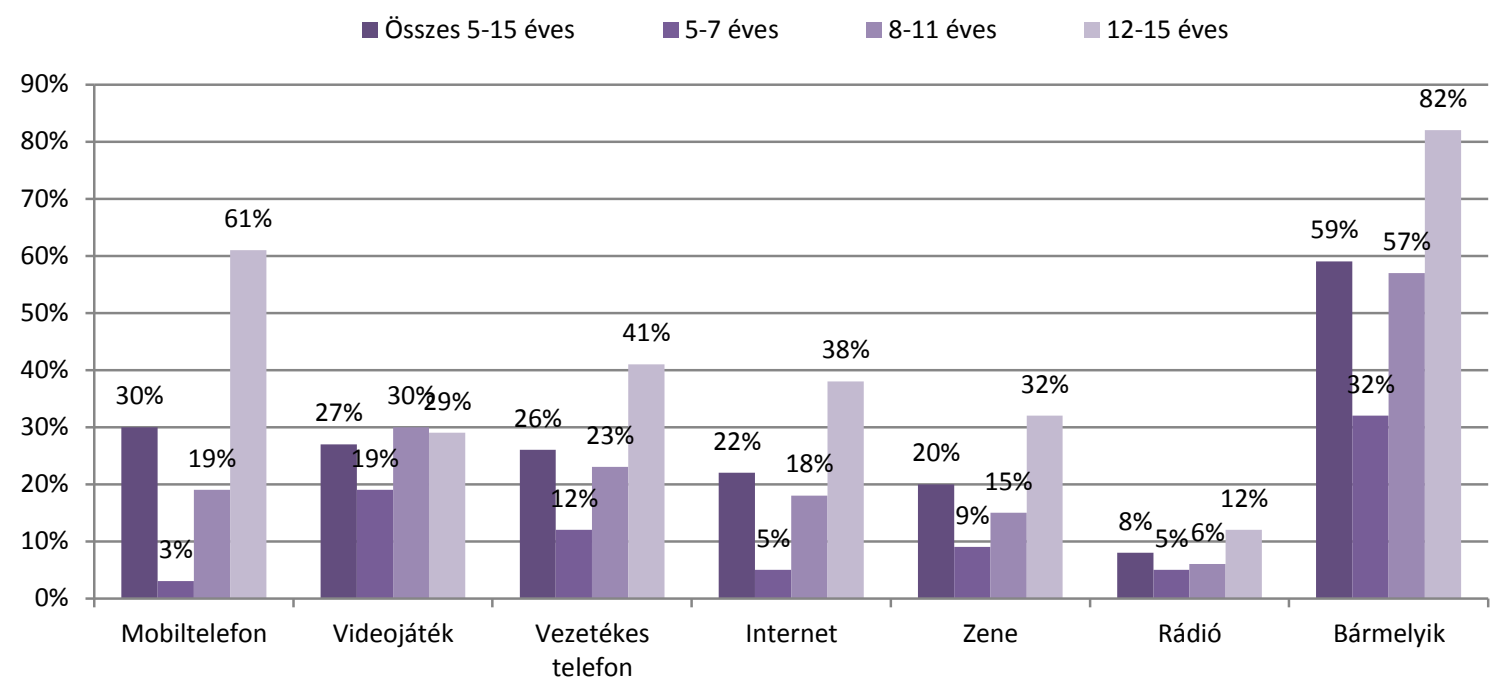

Az egyes médiumok és kommunikációs szolgáltatások nem egyforma mértékben alkalmasak a párhuzamos fogyasztásra: vannak a figyelmet és az érzékszerveket jobban lekötő, folyamatos koncentrációt igénylő tevékenységek, illetve olyanok, amelyek jól követhetők a háttérben is, vagy éppen szakaszos, rövid ideig tartó odafigyelést igényelnek.

Foehr (2006) az egyes médiafogyasztási formákat vizsgálta abból a szempontból, hogy milyen más tevékenységekkel járnak együtt. Az alábbi táblázatban azt láthatjuk, hogy a tévézésre fordított idő kevesebb, mint ötödében van jelen más média is. A relatíve 
alacsony arányhoz minden bizonnyal hozzájárul az is, hogy meglehetősen magas, heti 19 óra a tévézéssel töltött idő, ráadásul más, nem média-jellegű tevékenységek is együtt járhatnak a tévézéssel (pl. vacsora készítés, evés).

7. táblázat: Az televízió használata más médiumokkal (Forrás: Foehr, 2006)

\begin{tabular}{lcc}
\hline Tevékenység & $\begin{array}{c}\text { Párhuzamosság aránya } \\
\text { Televízió és zene }\end{array}$ & $\begin{array}{c}\text { Eltöltött idő (hét, óra) } \\
(\mathbf{1 8 . 9 1 )}\end{array}$ \\
\hline Televízió és videojáték & $5 \%$ & 0.98 \\
Televízió és olvasás & $3 \%$ & 0.50 \\
\hline Televízió és IM & $2 \%$ & 0.41 \\
\hline Televízió és számítógépes játék & $2 \%$ & 0.33 \\
\hline Televízió és házi feladat végzése (számítógépen) & $2 \%$ & 0.32 \\
\hline Televízió és más számítógép használat & $1 \%$ & 0.22 \\
\hline Televízió és e-mail & $1 \%$ & 0.17 \\
\hline Televízió és böngészés & $1 \%$ & 0.14 \\
\hline Televízió és más médium együttes használata & $1 \%$ & 0.12 \\
\hline
\end{tabular}

Az azonnali üzenetküldés funkció, az instant messenger ugyan meglehetősen leköti a felhasználó figyelmét, de leginkább csak az írás idejére, az üzenetek között mód van más tevékenység végzésére is. A kutatás idején az IM rendkívül népszerű volt a fiatalok, elsősorban a gyermekek körében, így nem meglepő, hogy az IM-mel töltött idő háromnegyede párhuzamosan zajlik más tevékenységgel.

8. táblázat: Az instant messenger (IM) használata más (Forrás: Foehr, 2006)

\begin{tabular}{lcc}
\hline Tevékenység & $\begin{array}{c}\text { Párhuzamosság aránya } \\
\text { Eltöltött idő (hét, óra) } \\
\text { (1.96) }\end{array}$ \\
\hline IM és zene & $20 \%$ & 0.38 \\
\hline IM és televízió & $17 \%$ & 0.33 \\
IM és számítógépes játék & $8 \%$ & 0.15 \\
IM és házi feladat végzése (számítógépen) & $8 \%$ & 0.15 \\
IM és böngészés & $7 \%$ & 0.15 \\
IM és e-mail & $6 \%$ & 0.11 \\
\hline IM és más számítógép használat & $5 \%$ & 0.09 \\
IM és olvasás & $3 \%$ & 0.07 \\
\hline IM és videojáték & $1 \%$ & 0.02 \\
\hline IM és más médium együttes használata & $74 \%$ & 1.45 \\
\hline
\end{tabular}

Az e-mailezés közben végzett párhuzamos tevékenységek jobban eloszlanak, mint az IM esetében tapasztalhattuk. Mint az alábbi táblázat mutatja, az offline tevékenységekkel fennálló párhuzamosság aránya valamelyest kisebb, míg az online szolgáltatások esetében nagyobb. 
9. táblázat: Az e-mail használata más médiumokkal (Forrás: Foehr, 2006)

\begin{tabular}{lcc}
\hline Tevékenység & Párhuzamosság aránya & $\begin{array}{c}\text { Eltöltött idő (hét, óra) } \\
\text { (0.88) }\end{array}$ \\
\hline E-mail és televízió & $16 \%$ & 0.14 \\
E-mail és zene & $14 \%$ & 0.12 \\
\hline E-mail és IM & $13 \%$ & 0.11 \\
\hline E-mail és más számítógép használat & $12 \%$ & 0.11 \\
\hline E-mail és számítógépes játék & $9 \%$ & 0.08 \\
\hline E-mail és házi feladat végzése (számítógépen) & $8 \%$ & 0.07 \\
\hline E-mail és böngészés & $6 \%$ & 0.05 \\
\hline E-mail és olvasás & $4 \%$ & 0.03 \\
\hline E-mail és videojáték & $2 \%$ & 0.02 \\
\hline E-mail és más médium együttes használata & $83 \%$ & 0.73 \\
\hline
\end{tabular}

A böngészés az egyetlen olyan online tevékenység, amely nagyobb mértékben jár együtt valamely más online alkalmazással (IM), mint a tévézéssel vagy a zenehallgatással. A böngészés és az azonnali üzenetek természetes párosítást alkotnak, amiben minden bizonnyal az is szerepet játszik, hogy a fiatalok sok üzenetben vicces linkeket küldözgetnek egymásnak, amit a címzett azonnal meg is néz.

10. táblázat: A webes böngészés használata más médiumokkal (Forrás: Foehr, 2006)

\begin{tabular}{lcc}
\hline Tevékenység & Párhuzamosság aránya & $\begin{array}{c}\text { Eltöltött idö (hét, óra) } \\
\text { (0.97) }\end{array}$ \\
\hline Böngészés és IM & $15 \%$ & 0.15 \\
\hline Böngészés és televízió & $12 \%$ & 0.12 \\
\hline Böngészés és zene & $12 \%$ & 0.11 \\
\hline Böngészés és számítógépes játék & $10 \%$ & 0.09 \\
\hline Böngészés és házi feladat végzése (szg-en) & $9 \%$ & 0.09 \\
\hline Böngészés és más számítógép használata & $7 \%$ & 0.07 \\
\hline Böngészés és e-mail & $5 \%$ & 0.05 \\
\hline Böngészés és olvasás & $3 \%$ & 0.03 \\
\hline Böngészés és videojáték & $1 \%$ & 0.01 \\
\hline Böngészés és más médium együttes használata & $74 \%$ & 0.71 \\
\hline
\end{tabular}

Baron (2006) megerősítette ezeket az eredményeket, az azonnali üzenetek, az e-mail, a zenehallgatás és a webes szörfölés azok a tevékenységek, amelyek az általa végzett kutatás szerint leginkább együtt járnak.

A média multitasking jelenséggel foglalkozó empirikus vizsgálatok a legtöbb esetben kvantitatív megközelítést alkalmaznak, valamilyen kérdőíves, vagy naplós módszerrel dolgoznak, leszámítva a kognitív kísérleteket. Viszonylag ritka a kvalitatív megközelítés, ebben jelent kivételt Hundley és Shyles (2010) vizsgálata, amely fókuszcsoportos beszélgetések alapján vizsgálja a 12-16 éves amerikai tinédzserek digitális médiahasználatát. A fókuszcsoportok (összesen 11 fókuszcsoport) során megjelent a 
párhuzamos használat is, sok válaszadó állította, hogy egy időben egyszerre több médiafunkciót is használ, például SMS-írás, videonézés, internetezés, online csevegés során. A megkérdezettek nagy része arról számolt be, hogy internetezés közben a háttérben zene szól, vagy be van kapcsolva a tévé.

„Mellettem van a PSP-m, be van kapcsolva a számítógép és a TV és mindegyiken egyszerre játszom."

„Amint hazaérek számítógépezek. Egész nap zenét hallgatok, folyamatosan.”

Az elhangzottak szerint sok tinédzser nincs tudatában annak, hogy mennyi időt tölt a digitális eszközök használatával. Számos elfoglaltság áll versenyben a tinédzserek idejéért, ami magyarázza a multitasking tevékenységüket. Gyakran elhangzott, hogy a tinédzserek a házi feladataikat a számítógépen írják, miközben zenét hallgatnak, akár a számítógépen, iPodon, vagy rádió segítségével vagy a háttérben be van kapcsolva a tévé. (Hundley - Shyles, 2010)

A kutatási terület aktualitását mutatja, hogy más kutatók épp a jelen lévő tudatosságot emelik ki. Kenyon (2008) longitudinális, naplós módszerrel készült 16 évesek és idősebbek körében kutatásából kiderül, hogy az elsődleges és a másodlagos tevékenységeket beosztása során a kutatásban részt vevők a kognitív figyelem alapján rangsorolnak, azaz a nagyobb figyelmet kívánó aktivitások lesznek jellemzően az elsődleges tevékenységek. Baron (2005) ezt az aktivitások kognitív/szociális egyensúlyának nevezi, ahol a magas kognitív megterheléssel járó tevékenységek többnyire elsődlegesek, a szociális aktivitások pedig másodlagosak. A kutatásból kiderül, hogy a multitasking szerepe sem elhanyagolható, Kenyon megjegyzi, hogy amennyiben csak az elsődleges tevékenységek kerültek volna rögzítésre az adatfelvétel során, akkor 37 százalékkal csökkent volna a részvevők online töltött ideje. 
11. táblázat: Elsődleges és másodlagos tevékenységekkel töltött idő (óra/hét; N=96) (Forrás: Kenyon, 2008)

\begin{tabular}{lccc}
\hline Tevékenység & Elsődleges & Másodlagos & Összesen \\
\hline Tanulás & 160 & 10 & 171 \\
\hline Információkeresés & 112 & 45 & 157 \\
\hline Munka & 1479 & 16 & 1494 \\
\hline Vásárlás & 154 & 32 & 186 \\
\hline Közösségi hálózatok & 594 & 1153 & 1747 \\
\hline Összes online tevékenység & 216 & 129 & 344 \\
\hline Összes utazás & 682 & 71 & 754 \\
\hline
\end{tabular}

A fenti táblázatból látható, hogy az online tevékenységek között a szociális jelleg dominál. Ezt erősíti, hogy a Pew Internet and American Life (2007) tanulmány szerint a közösségi hálózatokon töltött idő kétharmadában más tevékenységek is jelen vannak.

Kenyon (2008) kutatásából az is kiderül, hogy az elsődleges tevékenységek offline, illetve online történő végzése erős befolyással van a másodlagos tevékenységek megjelenésére, ami azt jelenti, hogy pl. az online információkeresés során nagyobb valószínűséggel van jelen másodlagos tevékenység szemben azzal, ha az információkeresés offline módon történik.

12. táblázat: Multitasking mértéke az elsődleges tevékenységekre fordított idő során (N=86) (Forrás: Kenyon, 2008)

\begin{tabular}{lccc}
\hline Elsődleges tevékenység típus & Összes idő & Az elsődleges offline & Az elsődleges online \\
\hline Tanulás & $23 \%$ & $21 \%$ & $63 \%$ \\
\hline Információkeresés & $43 \%$ & $39 \%$ & $45 \%$ \\
Munka & $28 \%$ & $28 \%$ & - \\
Vásárlás & $36 \%$ & $32 \%$ & $58 \%$ \\
Közösségi hálózatok & $56 \%$ & $59 \%$ & $39 \%$ \\
Összes online tevékenység & $45 \%$ & - & $45 \%$ \\
Összes offline tevékenység (pl. alvás) & $43 \%$ & $43 \%$ & - \\
Összes utazás & $60 \%$ & $60 \%$ & - \\
\hline
\end{tabular}

A kutatásban résztvevőket arról kérdezték, hogy az egyes tevékenységek online végzése melletti döntésben szerepet játszik-e az, hogy lehetőség van több tevékenység párhuzamos végzésére is, azt találták, hogy a kérdezettek mintegy harmadánál-felénél a multitasking lehetősége is szempontként jelent meg. Az alábbi táblázat is azt mutatja, hogy a válaszadók legalább háromnegyede szerint az aktivitások online végzése elősegíti a multitaskingot. 
13. táblázat: Többet tud-e multitaskingolni az alábbi tevékenységek végzése mellett, ha online végzi azokat (Forrás: Kenyon, 2008)

\begin{tabular}{lccccc}
\hline & $\mathbf{N}$ & Igen & Nem & Néha & Nem tudja \\
\hline Bevásárlás (grocery shopping) & 116 & $74 \%$ & $4 \%$ & $22 \%$ & $0 \%$ \\
Vásárlás (non-grocery shopping) & 291 & $81 \%$ & $4 \%$ & $13 \%$ & $2 \%$ \\
Kommunikáció (barátokkal, családdal) & 468 & $81 \%$ & $3 \%$ & $15 \%$ & $1 \%$ \\
Tanulás (formális) & 112 & $55 \%$ & $10 \%$ & $32 \%$ & $3 \%$ \\
Információkeresés & 478 & $85 \%$ & $2 \%$ & $13 \%$ & $1 \%$ \\
\hline
\end{tabular}

A nemzetközi empirikus kutatások a média és kommunikációs multitaskinggal kapcsolatban megállapítják, hogy az infokommunikációs fejlődés mellett a médiafogyasztás belső szerkezete is alapvetően megváltozott, új fogyasztási stílusok, összetettebb fogyasztói csoportok alakultak ki.

A megjelenő új hozzáférési módok, szolgáltatások, tartalmak csak részben veszik át a régiek helyét, inkább a hagyományos tevékenységek mellé rendeződnek. Megfigyelhető, hogy a médiahasználat összesített időtartama nem, vagy alig változott, amely szinte kizárólag a média és kommunikációs multitaskingnak köszönhető, ami az idősoros médiafogyasztási adatok tanúsága szerint teljességgel köznapi viselkedéssé vált napjainkra.

A kutatások általános megállapítása, hogy a média és kommunikációs multitasking a fiatalabb korcsoportban hatványozottabban van jelen. További fontos tényezőt jelent a rendelkezésre álló eszközök száma és specifikációja, a tevékenységek jellege. 


\section{AZ EMPIRIKUS VIZSGÁLATOK MÓDSZERTANA}

Az egyidejű többcsatornás médiafogyasztás csupán néhány éve került a kutatók szélesebb rétegeinek fókuszába. Az időmérleg-vizsgálatokat és a kognitív pszichológiát követően a marketing és reklámpiacon tevékenykedők számára vált különösen érdekessé, a hirdetések célba éréséhez ugyanis elengedhetetlenül fontos a célközönség figyelme. A párhuzamos fogyasztás jelensége ezt a folyamatos figyelmet veszélyeztetheti, ezért olyan megoldások kifejlesztésére ösztönöz, amely hatékonyan képes az üzeneteket eljuttatni a célcsoporthoz.

Mintegy hat évvel ezelőtt, amikor kutatási érdeklődésem a média és kommunikációs multitasking felé fordult a téma „frissessége” egyben azt is jelentette, hogy nem állt rendelkezésre alaposan kimunkált szakirodalom, leginkább különböző piac- és marketing jellegű kutatási anyagok voltak elérhetőek, elméleti munka viszonylag kevés volt és azok sem a szúken vett tématerületre koncentráltak. Ma már természetesen más a helyzet, ahogy a dolgozat elméleti fejezetében is látszik főként a kognitív tudomány fedezte fel újra a területet, de bekapcsolódnak más társadalomtudományi megközelítések is. Az azóta eltelt idő alatt lehetőségem volt több empirikus kutatási projektet vezetni (vagy részt venni bennük, vagy a nyers eredményekhez, adatbázisokhoz hozzájutni), ahol az adott kutatási projekt keretein belül igyekeztem a megváltozó médiafogyasztási és kommunikációs szokásokat és azokban a párhuzamosság különböző vetületeit vizsgálni.

Az alábbi ábrán is látható, hogy a munka megkezdése óta gyakorlatilag minden évben sikerült valamilyen empirikus kutatással vizsgálni a párhuzamos fogyasztást. Ez történhetett általánosságban, mint a World Internet Project esetében, vagy egy-egy jól körülhatárolható problémára koncentrálva, mint az Excenter keretei belül végzett munkakörnyezethez kötődő infokommunikációs eszközhasználatban megjelenő párhuzamosság. 
14. ábra: Az empirikus kutatássorozat folyamata és részei

\section{$\stackrel{0}{0}$}

Nagymintás (4000

fő) kérdőíves

kutatás (PAPI) az

internet-

használatról

(WIP)

Fókuszcsoportos

kutatás a fiatalok

párhuzamos

médiafogyasztá-

sáról (BCE)

\section{$\vartheta^{\infty}$}

Online kérdőíves kutatás (CAWI;

1000 fő) a

párhuzamos

médiafogyasztás-

ról (ITTK-NRC)

\section{$0^{0}$}

Nagymintás (2500

fő) kérdőíves

kutatás (PAPI) az

internet-

használatról

(WIP)

\section{뭄}

Kérdőíves kutatás az ELTE Radnóti Miklós Gyakorlógimnáziumban,

internet-

használatra

vonatkozó

tematikával

(Tükörterem)
궁

Fókuszcsoportos és interjús kutatás a munkahelyi

info-

kommunikációs eszköz-

használatról, párhuzamos használatról

(Excenter)
N

Online kérdőíves kutatás

(CAWI; 1000 fó) a

médiafogyasztásról,

benne a parhuzamos

fogyasztásról

(Kutatópont)

Nagymintás (3x2000 fó)

kérdőíves kutatás (CAPI)

a médiafogyasztási

szokásokról, benne a

média és kommunikációs

multitaskingról

(Kutatópont)

Magyar Ifjúság 2012 -

nagymintás kérdőíves

kutatás (8000 fős CAPI) a

fiatalok életmódjáról

élethelyzetéről,

fogyasztási szokásairól

benne a párhuzamos

médiafogyasztásról

(Kutatópont) 


\subsection{AZ EMPIRIKUS VIZSGÁLATOK KÖRNYEZETE ÉS TEMATIKÁJA}

A kutatás empíriájának egyik részét a World Internet Project (WIP) magyarországi longitudinális, kérdőíves vizsgálata képezi, amelyből folyamatosan válasz kapható a médiafogyasztás mennyiségi alakulásáról, az egyes médiumok az egyén életében betöltött szerepéről (szubjektív fontosság), illetve a multitasking jelenségének terjedéséről és szociodemográfiai sajátosságairól. A World Internet Project (WIP) az internet társadalmi hatásainak vizsgálatára szerveződött széleskörű nemzetközi kutatási program, amelyet 1999-ben a kaliforniai UCLA Center of Communications Policy és a szingapúri NTU School of Communications Studies kezdeményezett. A WIP jelentősége számos szempontból egyedülálló. Egyrészt a szokásos internetes kutatások témakörén túlmutató attitűd-, érték- és viselkedésváltozók szerepeltetésével mélyebb értelmezéseket tesz lehetővé, másrészt a vizsgálat kiterjed az internetet nem használó személyekre is, ezáltal kívánja feltérképezni a távolmaradás okait. Harmadrészt a vizsgálat nemzetközi, longitudinális, emellett panel jellegű, amely nemzetközi összehasonlítást, illetve évenkénti összehasonlítást tesz lehetővé. Magyarország 2001 óta vesz részt a WIP projektben (én 2005-ben kapcsolódtam be a munkába), az azóta eltelt időszakban nyolc adatfelvételre került sor. Az adatfelvételért és a gyorselemzésért felelős Tárki Rt.-hez a kutatásban társintézetként közreműködő BME-ITTK (Információs Társadalom- és Trendkutató Központ) mellett 2002-ben csatlakoztak az ELTE Szociológiai Intézetében 2002 ősze óta működő Információs Társadalom és Hálózat Kutató Központ (ITHAKA) kutatói. Fontos azonban megjegyezni, hogy a kutatás finanszírozása nem központi alapokból történik, vagyis nem az alapítók biztosítják a forrásokat, s ezért a vizsgálathoz minden esetben a csatlakozó szereplők (piackutatók, tudományos intézetek, stb.) teremtik elő az anyagiakat, s így az adatok is az ő birtokukban vannak. Ennek következtében vannak olyan országok, amelyeknek az adataihoz könnyebben hozzá lehet férni (pl. USA, Svédország, Japán vagy éppen Magyarország, míg más országokban még az amerikai kutatók is csak aggregált adatokat kapnak). Ritka az olyan ország, ahol - hazánkhoz hasonlóan - a kutatásról készülő éves gyorsjelentésen túl még az adatbázist is megkaphatják az érdeklődők.

A World Internet Project során alkalmazott kérdőívek (főkérdőív és internetezők kérdőíve) tematikájában a párhuzamos fogyasztás az internetezéshez kapcsolódóan 
jelenik meg és mindössze egyetlen kérdésben próbálja megragadni a halmozott használatot, amely a következő:

Szokott Ön internetezés közben más tevékenységet is folytatni, például telefonálni, zenét hallgatni, vagy tévét nézni?

1 - Igen, gyakran előfordul,

2 - ritkán fordul elő, vagy

3 - soha nem szokott?

9 - NT X -

A kérdésből kiderül, hogy ezt kizárólag az internetezőktől kérdeztük, így az internetezéshez nem kapcsolódó média és kommunikációs multitaskingról a WIP nem nyújthat információkat. Ugyanakkor a WIP kutatássorozatnak számos más előnye van, hiszen alapos vizsgálat tárgyává teheti a médiafogyasztást, azáltal, hogy az egyes médiumok fogyasztási gyakoriságára és mennyiségére is vonatkoznak kérdések.

Ön milyen gyakran foglalkozik a következő, nem számítógépes tevékenységekkel? Kérem, hogy az "1. VÁLASZLAP" segítségével válaszoljon!

a. könyvolvasás

b. játék videojátékokkal

c. zenehallgatás (CD-ről, kazettáról, MP3 lejátszóról)

d. újságolvasás

e. rádióhallgatás

f. telefonálás

g. televízió nézés

1. VÁLASZLAP

1 - naponta, naponta többször

2 - hetente többször

3 - hetente egyszer

4 - havonta többször

5 - havonta egyszer, vagy ritkábban

6 - soha

HA 1-5-ös KÓDOT JELÖLTÉL: És egy átlagos héten összesen a szabadidejéből mennyi időt fordít erre a tevékenységekre?

...óra ...perc

Ezek alapján a nagymintás kutatássorozat különböző médiafogyasztási tipológiák készítésére is alkalmas, mint az a későbbiekben bemutatom a „Médiafogyasztási trendek, tipológiák" című fejezetben. A WIP erénye továbbá, hogy nem csupán a fogyasztásra vonatkozó, hanem az egyes médiumokhoz kapcsolódó attitűdök elemzésére is alkalmas. A későbbiekben bemutatom az egyes médiumok fontosságának megítélését mint információforrást, illetve mint a szórakozás eszközét. 
Mennyire fontos az Ön számára az internet, mint információforrás? Osztályozzon úgy, hogy az ötös azt jelentse, nagyon fontos, az egyes pedig, hogy egyáltalán nem fontos. (Természetesen a közbülső osztályzatokat is használhatja.)

MIUTÁN VÁLASZOLT: Abból a szempontból is osztályozza le az Internetet, hogy mennyire fontos az Ön számára, mint szórakozás.

És mennyire fontosak az Ön számára a következő, nem internetes információforrások?

És mennyire fontos, mint szórakozás?

a. az internet?

b. a könyvek?

c. a televízió?

d. a rádió?

e. újságok?

f. helyi klubok, társadalmi szervezetek, vallási közösségek?

g. a barátai, a családja?

A kutatássorozat adatfelvételei a legtöbb esetben ${ }^{70} 14$ éves és idősebb magyarországi lakosok véletlen mintáján történtek. A kutatássorozat mintái úgynevezett kétlépcsős, arányosan rétegzett valószínűségi mintavétellel készültek, ahol az első lépcsőben települési minta került kiválasztásra, majd a mintavétel második lépcsőjében egyszerű véletlen kiválasztással címlista összeállítása történt. A mintába került személyeket a kérdezőbiztosok személyesen keresték meg.

A minta címkiesésből adódó torzulásainak korrigálására szolgáló súlyozás a következő négy társadalmi-demográfiai tényező: nem, életkor, iskolai végzettség és településtípus együttes megoszlásának figyelembevételével történt. Így a súlyozott minta ${ }^{71}$ nem, életkor, településtípus és iskolai végzettség szerinti megoszlása jól illeszkedik a 14 év feletti lakosság megfelelő adataihoz.

2007-ben a Budapesti Corvinus Egyetem keretei között Urbán Ágnessel kvalitatív kutatást készítettünk a fiatalok médiafogyasztási szokásainak megváltozásáról. A fókuszcsoportos kutatás során megvizsgáltuk, hogy a különböző kommunikációs szintek összecsúszása, a párhuzamos fogyasztás a magyar fiatalok körében is felismerhető-e és ha igen, ez milyen hatással van a kommunikációs és médiafogyasztási szokásokra. A fókuszcsoportos beszélgetéseket négy fő téma szerint alakítottuk:

\footnotetext{
${ }^{70}$ A 2009-es minta már csak a 18 év feletti magyarországi népességre vonatkozik.

${ }^{71} \mathrm{~A}$ súlyozást követően rendszerint kétféle súly is rendelkezésre áll az adatok elemzéséhez, az egyéni súlyok mellett háztartási súlyok is készültek, mivel háztartásonként csak egy személy került a mintába. Számos kérdésben nem a személyek jelentik a vizsgált sokaságot, hanem a magyarországi háztartások.
} 
Médiafogyasztási szokások

- Először is azt szeretném megkérdezni, hogy kinek van saját televíziója otthon? Hol található a TV a lakásban? És a számítógép?

- Mennyi szabadidőtök van egy nap? Mivel szoktátok elfoglalni magatokat? Ha nem említik $\rightarrow$ és a televízió, rádió, nyomtatott sajtó, zene, internet?

- Mit gondoltok a korosztályotokba tartozókról, ők hogyan fogyasztanak médiát?

- Van-e olyan a fenti médiumokhoz tartozó tevékenység, amely kizárólag a szabadidőhöz kötődik? (Vannak-e kifejezetten „szabadidős” médiumok, és melyek azok, amelyeket munkatanulás mellett is lehet fogyasztani?)

Internethasználati szokások

- Nagyjából mennyi időt töltötök az internet előtt?

- Tipikusan milyen tevékenységeket végeztek az interneten? (Táblára!) Ha sorba kellene rakni, melyikkel töltötök a legtöbb időt? És melyik számotokra a legfontosabb? (Mit gondoltok, mi a jellemző a korosztályotokra általában?)

- Hogyan interneteztek? Van-e bejáratott módja annak, ahogyan az internetet használjátok (kedvenc lapok végiglátogatása, csetszoba, stb.)?

Párhuzamos fogyasztás az interneten

- Milyen tevékenységeket szoktatok/lehet egyszerre végezni a számítógépen/interneten? (Online rádióhallgatás, zenehallgatás, játék, online, vagy tv-kártyás tévézés, böngészés, azonnali üzenetküldőkön (pl. messenger, Skype) keresztül történő csevegés, e-mail írás/olvasás) (Táblára!)

- Mit gondoltok, mi a jellemző a korosztályotokra általában?

- Mely internetes tevékenységeket lehet/kell/kifejezetten jó egyszerre végezni? (Táblára!) Okoz-e bármilyen nehézséget egyszerre több dologra figyelni?

Párhuzamos fogyasztás (internet és hagyományos médiumok)

- Szoktatok-e számítógépezés, internetezés közben hagyományos módon (nem a számítógépen keresztül) televíziót nézni? Milyen helyzetekben, internetes tevékenységeknél tévéztek (vagy fordítva)?

- Szoktatok-e számítógépezés, internetezés közben hagyományos módon (nem a számítógépen keresztül) rádiót hallgatni? Milyen helyzetekben, internetes tevékenységeknél szoktatok rádiót hallgatni (vagy fordítva)?

- Szoktatok-e számítógépezés, internetezés közben hagyományos módon (nem a számítógépen keresztül) újságot/magazint olvasni? Milyen helyzetekben, internetes tevékenységeknél szoktatok újságot/magazint olvasni (vagy fordítva)?

- Mely médiumok „férnek meg” leginkább egymás mellett? Okoz-e bármilyen nehézséget egyszerre több dologra figyelni?

- Melyek azok a médiumok, amelyek a legkevésbé férnek meg egymás mellett?

Összesen négy fókuszcsoportot szerveztünk 6-8 fiatal résztvevővel Budapesten, elkülönítve egymástól a fiatalabbakat 14-18 és az idősebbeket 19-23 és az előzetes szűrőkérdőív által párhuzamos médiafogyasztást gyakorló és kontrollcsoportokba rendeztük őket. Az egyes fókuszcsoportok nagyjából 1,5-2 órát tartottak. Ez a kutatás kvalitatív megközelítése miatt nemzetközi mércével mérve is különlegesnek számít, ugyanis mint a nemzetközi kutatási eredményeket bemutató részben láthattuk viszonylag kevés kvalitatív megközelítéssel készülő párhuzamos médiafogyasztással foglalkozó vizsgálat készült az elmúlt években. 
A korábbi kutatási eredmények arra engednek következtetni, hogy a számítógéphasználók és internetezők körében a média multitasking sokkal gyakoribb tevékenységnek számít, mint azok körében, akik távol maradnak ezektől az eszközöktől. Lehetséges tehát az egész lakosságra vonatkozó offline kérdőíves módszer mellett online lekérdezést is alkalmazni, célzottan a szimultán fogyasztás felmérésére.

A kutatásban az általános médiafogyasztási jellemzők mellett a párhuzamos fogyasztás különböző online és hagyományos szintereit is megvizsgáltuk, illetve áttételesen foglalkoztunk a párhuzamos fogyasztás a figyelemre gyakorolt esetleges hatásaival is.

Szokott-e Ön számítógépezés, internetezés közben hagyományos módon (nem a számítógépen keresztül) rádiót hallgatni? (1 = Sohasem hallgatok rádiót számítógépezés, internetezés közben 234 5 = Nagyon gyakran hallgatok rádiót számítógépezés, internetezés közben)

Szokott-e Ön számítógépezés, internetezés közben hagyományos módon (nem a számítógépen keresztül) televíziót nézni? (1 = Sohasem tévézek számítógépezés, internetezés közben $2345=$ Nagyon gyakran tévézek számítógépezés, internetezés közben)

Milyen gyakran fordul elő eközben, hogy a televízión nézett műsornál elveszti a fonalat? $(1$ = Soha 23 45 = Nagyon gyakran)

Mennyire megerőltető (lenne megerőltető) az Ön számára a különböző online tevékenységek mellett a televízióra is figyelni?

1 - egyáltalán nem okoz nehézséget

2 - inkább nem okoz nehézséget

3 - inkább nehézséget okoz

4 - kifejezetten nehézséget okoz

A következőkben KIZÁRÓLAG A SZÁMÍTÓGÉPEN ÉS AZ INTERNETEN VÉGZETT KÜLÖNBÖZŐ TEVÉKENYSÉGEIVEL kapcsolatban szeretnénk kérdezni. Milyen számítógépes, internetes tevékenységek esetében jellemző, hogy Ön közben más ugyancsak a számítógéphez kötődő tevékenységet is végez? (pl. online rádiózás közben szokott-e böngészni?, stb.) Értékelje aszerint, hogy végez-e más tevékenységet az alábbi számítógépes tevékenységek közben. 1-es, ha sohasem végez más tevékenységet a felsoroltak közben, 5-ös, ha (szinte) mindig! Természetesen használhatja a közbülső értékeket!

a. online rádióhallgatás

b. zenehallgatás

c. játék

d. online, vagy tv kártyás tévézés

e. böngészés

f. azonnali üzenetküldőkön (pl. MSN, Skype) keresztül történő csevegés

g. e-mail írás/olvasás

Mennyire megerőltető (lenne megerőltető) az Ön számára, ha különböző számítógépes-internetes tevékenységeket egyszerre kell végeznie?

1 - egyáltalán nem okoz nehézséget

2 - inkább nem okoz nehézséget

3 - inkább nehézséget okoz

4 - kifejezetten nehézséget okoz 
Ezek az online kutatások lehetővé tették, hogy a párhuzamos fogyasztást más megközelítéssel is megvizsgálhassuk. Azt is megkérdeztük a kérdőív kitöltőitől, hogy mialatt a kérdésekre válaszoltak milyen egyéb, főként médiajellegű és kommunikációs tevékenységet végeztek.

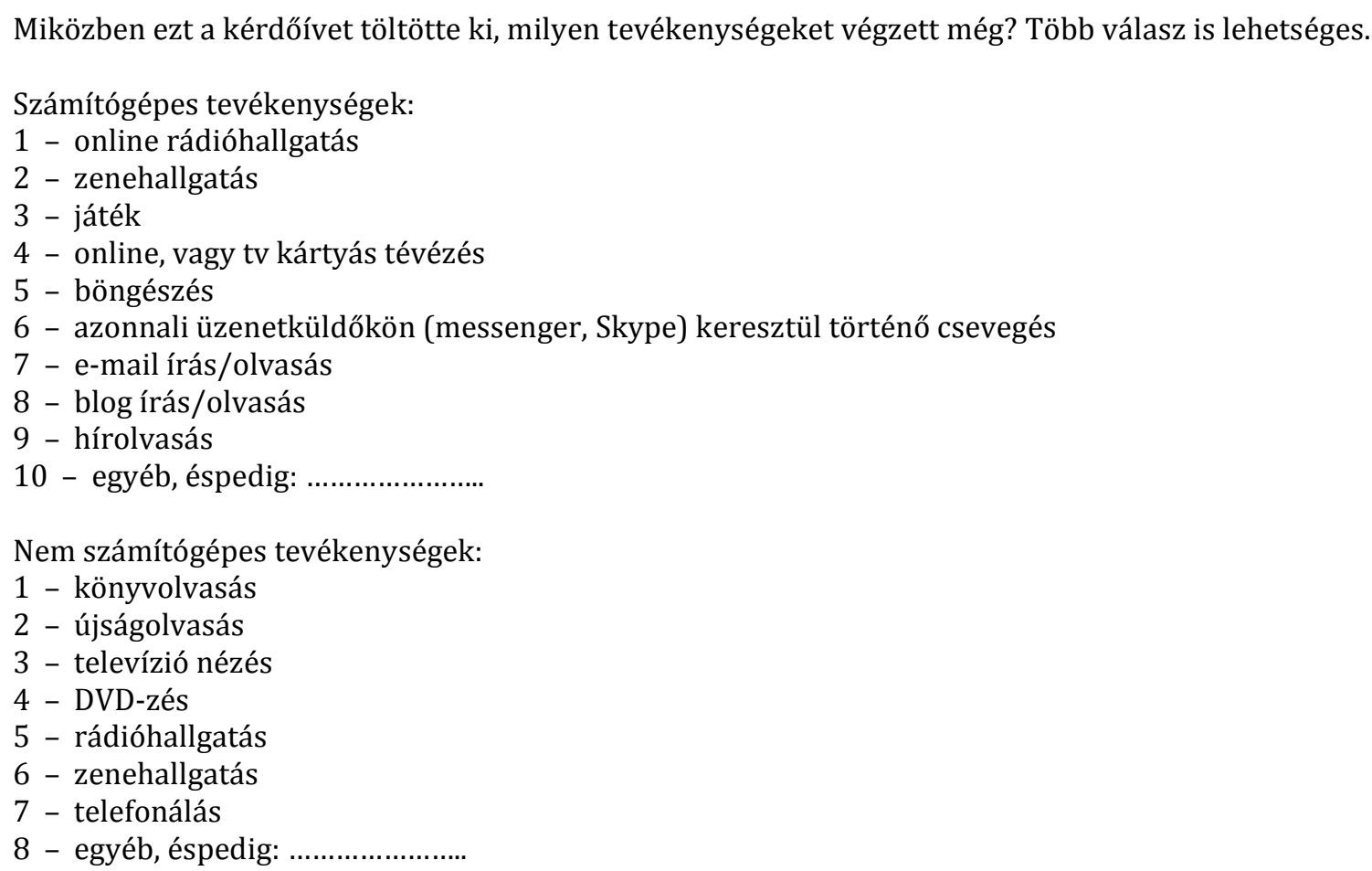

A kutatások a magyar internetezőkre reprezentatív, 1000 fős mintán, néhány perces kérdőívvel készültek, 2008 elején az NRC Piackutató és BME-ITTK keretei között, majd a kutatást részben megismételve 2012-ben a Kutatópont berkein belül.

Az empirikus munka fontos része az a fiatalokra koncentráló speciális módszertannal felvértezett kutatás, amely az ELTE Radnóti Miklós Gyakorlógimnáziumban készítettünk 2010-ben a Tükörterem Társadalomkutató Műhely oktatáskutatással foglalkozó kutatócsoportjának keretei között. A kutatás célja a tanulással és az iskolával kapcsolatos diák és szülői vélemények megismerése, ehhez kapcsolódóan az oktatás színvonalának, a nevelés hatékonyságának megítélése, a tehetséggondozási igények, továbbtanulási tervek, stb. alapos körüljárása. A kutatásban lehetőségünk volt megvizsgálni a gyerekek internethasználatát különböző rekreációs és erőforrás-bővítő tevékenységek során, a kutatás fő tematikájának megfelelően részletezve a tanulással kapcsolatos internethasználatot, továbbá részletesen feltérképeztük a számítógép- és internethasználattal kapcsolatos családi segítségnyújtás rendszerét. 
Milyen gyakorisággal használod a számítógépet, internetet az alábbiakra... (minden nap; hetente párszor; havonta többször; ritkábban; soha)

a. a tanuláshoz, iskolával kapcsolatos dolgokra (pl. házi feladat; dolgozat; stb)

b. játékra (offline és online)

c. közösségi tevékenységekre (chat; iWiW; MSN; e-mail; Facebook, fórum; stb.)

d. szórakozásra (zenehallgatás; filmnézés; stb.)

Amennyiben a tanuláshoz is használod az internetet, az alábbiakat milyen gyakran használod? (minden nap; hetente párszor; havonta többször; ritkábban; soha)

a. keresőoldalak (Google, Bing, stb.)

b. Wikipedia

c. tematikus linkgyüjtemények (pl.: lap.hu oldalak)

d. elektronikus szótárak

e. online nyelvi tesztek

f. vizsgatesztek (pl.: érettségi)

g. segédanyag, dolgozat gyújtőoldalak

Mennyire jellemző, hogy otthon... (minden nap; hetente párszor; havonta többször; ritkábban; soha)

a, segítesz a szüleidnek, a számítógép, internet használatában

b, a szüleid segítenek neked a számítógép, internet használatában

c, szüleiddel együtt internetezel

d, beszélgettek az interneten általad látottakról

A kutatásunk tervezésekor fontos szempontként merült fel, hogy az egyidejű adatfelvétel és az egymásra reflektáló kérdőívek tegyék lehetővé az összehasonlításokat a célcsoportok között azon túlmenően, hogy az adott kérdésekről hogyan gondolkodnak általában a szülők és diákok. A teljesebb összehasonlítás lehetőségét és ennek a kutatásnak a különlegességét az adja, hogy a szülők és gyermekeik válaszait az anonimitás megőrzése mellett összekötöttük. Az összekötést kódszámok segítségével végeztük, amelyeket az adatbázisok egyesítése után megsemmisítettünk. Az adatbázisok egyesítése után összességében 626 esetben sikerült a családokat (szülők és gyermekeik válaszait) egyesíteni. Mindez azt jelenti, hogy lehetőség nyílik a családok vizsgálatára is, azaz a diákok és szüleik válaszai összeköthetők és összevethetők.

Egy az Excenter Kutatóközpont berkeiben, 2011-ben végzett kvalitatív kutatás során fókuszcsoportos és interjús technikával tártuk fel az irodákban, infokommunikációs eszközökkel dolgozók szokásait, és a munkaadók attitűdjeit. A fókuszcsoportos kutatási szakaszban összesen négy csoporttal dolgozhattunk, olyanok (csoportonként 6-8 fó) részvételével, akik közepes, vagy nagyobb állami, piaci cégnél, munkaidejük nagy 
részében számítógéppel dolgoznak. A csoportokba vegyesen szerepeltek nők és férfiak, különböző iskolai végzettségű és különböző korcsoportba tartozó aktív munkavállalók.

A kutatás fő célkitűzése a magán- és munkajellegű tevékenységek összecsúszásának vizsgálata, a munkahelyi magáncélú infokommunikációs eszközhasználat mértékének, motivációinak és a munkaadó viszonyulásának, stratégiájának megismerése volt. A fókuszcsoportos kutatási szakaszban sort kerítettünk a munkakörnyezetben az infokommunikációs eszközökhöz kötődő multitasking vizsgálatára is, az alábbiak szerint:

Halmozott használat

- $\quad$ Milyen gyakori, hogy egyszerre több mindent is csináltok az interneten? (pl. egyszerre több alkalmazás van megnyitva)

- Véleményetek szerint az egyszerre végzett különböző tevékenységek befolyásolják-e a teljesítményt? Ha igen, hogyan?

- Vannak-e olyan tevékenységek, amelyek elősegítik és vannak-e olyanok, amelyek gátolják a minőségi munkavégzést? (pl. pihentető zenehallgatás; cigarettaszünet; stb.)

A vállalatvezetőkkel készült interjúkban elsősorban a munkahelyen, az infokommunikációs eszközökön történő magánjellegű tevékenységekkel kapcsolatos céges policy-k létét és azok tartalmát vizsgáltuk.

A Kutatópont Közvélemény és Piackutató által gondozott rendszeres nagymintás kérdőíves kutatás a magyar felnőttek médiafogyasztási szokásait vizsgálja. Célja, hogy átfogó képet nyújtson a magyar társadalom médiapreferenciáiról és médiafogyasztási szokásairól, amelyre az alkalmazott módszertan és a mintanagyság mindenképpen alkalmassá teszi. A kutatás keretében a következő kérdéskörökkel foglalkoztunk:

- televízió, számítógép és internet-hozzáféréssel

- a vezetékes és a mobiltelefon penetrációval

- a mobiltelefonos funkciók használati gyakoriságaival

- megvizsgáljuk a médiafogyasztás mennyiségi tényezőit

- a médiumok népszerűségét típusonként vizsgáljuk (napilapok és hetilapok olvasottsága; tv-csatornák népszerűsége; rádióadók hallgatottsága; internetes oldalak látogatottsága)

- vizsgáljuk az információszerzés szempontjából fontos médiumokat

- vizsgáljuk az egyes médiumok hitelességének megítélését

- rendszeresen vizsgáljuk továbbá az online aktivitásokat, így az új (online) fogyasztási szokásokat, a blogok, illetve a közösségi oldalak szerepét 
A médiafogyasztás mennyiségére vonatkozó kérdések a WIP kutatásokkal ellentétben nem átlagos hétre, hanem átlagos napra és átlagos hétvégére vonatkoznak, ami szintén lehetővé teszi a heti médiafogyasztás változó képzését, de az elkülönítés lehetőséget ad a hétköznap és a hétvége elválasztására is.

Egy átlagos hétköznap, mennyi időt (hány órát és hány percet) tölt Ön...?

És egy átlagos hétvégén (a két napon együtt), mennyi időt (hány órát és hány percet) tölt Ön...?

a. könyvolvasással

b. újságolvasással

c. televízió-nézéssel (televízió-műsor)

d. DVD-zéssel, film, vagy más video nézéssel

e. internetezéssel

f. rádióhallgatással

g. zenehallgatással

A World Internet Project esetében már megismert médiumok fontosságára vonatkozó kérdéseket a Kutatópont médiafogyatásra vonatkozó kutatásában is használjuk kiegészítve az egyes médiumok hitelességének értékelésével. 
A következőkben a médiafogyasztásáról szeretnénk kérdezni. Hetente átlagosan mennyi időt (órát és percet) tölt Ön azzal, hogy a SZÁMÍTÓGÉPEN, VAGY INTERNETEN (laptopot, kéziszámítógépet is beleértve)...
a. könyvet olvas
b. újságot olvas
c. televízióadást néz
d. (online) rádiót hallgat
e. zenét hallgat

Mennyire fontos az Ön számára a ..., mint információforrás és mennyire mint szórakozás? Osztályozzon úgy, hogy az ötös azt jelentse, nagyon fontos, az egyes pedig, hogy egyáltalán nem fontos. (Természetesen a közbülső osztályzatokat is használhatja.) Tehát mennyire fontos az Ön számára a .... mint információforrás?

MIUTÁN VÁLASZOLT: Abból a szempontból is osztályozza le ..., hogy mennyire fontos az Ön számára, mint szórakozás.

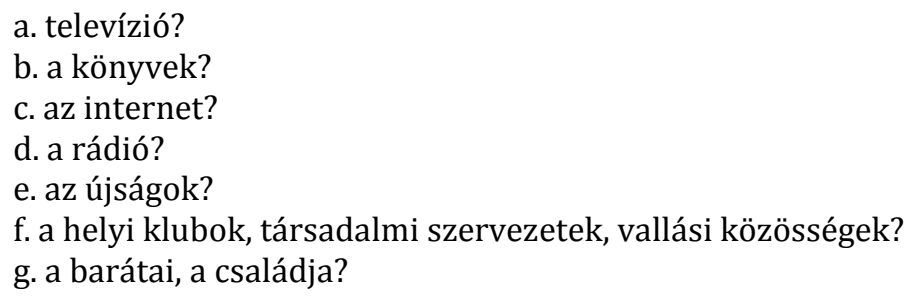

És mennyire tartja információszerzés szempontjából megbízhatónak, hitelesnek ÁLTALÁBAN ...? Osztályozzon úgy, hogy az ötös azt jelentse, teljes mértékben, az egyes pedig, hogy egyáltalán nem. (Természetesen a közbülső osztályzatokat is használhatja.) Tehát mennyire tartja információszerzés szempontjából megbízhatónak, hitelesnek ÁLTALÁBAN ...

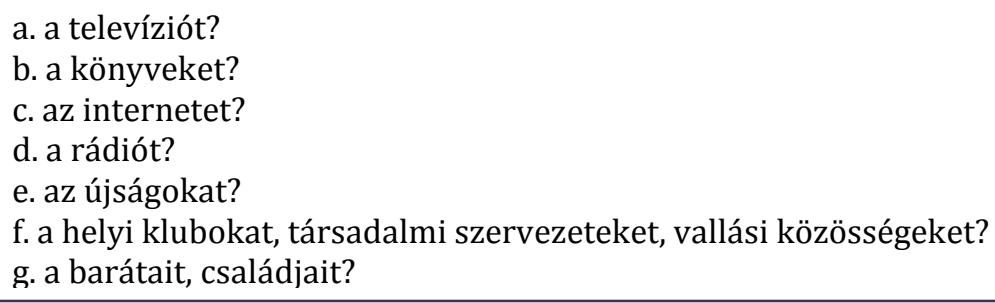

A kutatásban használt kérdőívekben külön kérdésblokkban foglalkozunk a média multitasking jelenségével, azon belül a számítógépes-internetes tevékenységekhez kötődő hagyományos médiafogyasztással, illetve kifejezetten a számítógéphezinternethez kötődő párhuzamos fogyasztással. 
Szokott-e Ön számítógépezés, internetezés közben hagyományos módon (nem a számítógépen keresztül)? Értékelje aszerint, hogy végez-e más tevékenységet számítógépezés, internetezés közben. 1-es, ha sohasem végez más tevékenységet, 5-ös, ha (szinte) mindig! Természetesen használhatja a közbülső értékeket!

a. rádiót hallgatni

b. televíziót nézni

c. újságot, könyvet olvasni

d. zenét hallgatni

A következőkben KIZÁRÓLAG A SZÁMÍTÓGÉPEN ÉS AZ INTERNETEN VÉGZETT KÜLÖNBÖZŐ TEVÉKENYSÉGEIVEL kapcsolatban szeretnénk kérdezni.

Milyen SZÁMÍTÓGÉPES, INTERNETES tevékenységek esetében jellemző, hogy Ön közben más ugyancsak a számítógéphez kötődő tevékenységet is végez? (pl. online rádiózás közben szokott-e böngészni?, stb.) Értékelje aszerint, hogy végez-e más tevékenységet az alábbi számítógépes tevékenységek közben. 1-es, ha sohasem végez más tevékenységet a felsoroltak közben, 5-ös, ha (szinte) mindig! Természetesen használhatja a közbülső értékeket!

a. online rádióhallgatás

b. zenehallgatás

c. játék

d. online, vagy tv kártyás tévézés

e. böngészés

f. azonnali üzenetküldőkön (pl. MSN, Skype) keresztül történő csevegés

g. e-mail írás/olvasás

h. közösségi oldalak böngészése (pl. iWiW, Facebook)

A kutatássorozat adatfelvétele 2000 fős, a magyarországi felnőtt lakosságot kor, nem, iskolai végzettség és lakóhely szerint reprezentatív mintán, CAPI-rendszerrel, 40-45 perces kérdőívvel készült három hullámban: 2012 tavaszán (első hullám), nyarán (második hullám) és őszén (harmadik hullám).

Az empirikus adatok közül legfrissebb forrás a Magyar Ifjúság 2012 kutatás, amelynek során 8000, 15-29 éves fiatalt kérdeztünk meg, egy hozzávetőlegesen 70 perces kérdőívvel 2012. szeptember és november között. A kutatás reprezentatív a 15-29 éves magyar népességre nézve területileg, településtípusonként, korcsoportok és nemek szerint. A mintavétel két lépcsőben történt, rétegzett valószínűségi mintavételi módszer alkalmazásával. Első lépcsőben a vizsgálandó települések, második lépcsőben az adott települések felkeresendő címeinek kiválasztására került sor. A nagy mintának köszönhetően pontosabb becslések adhatók a korosztály jellemzőit illetően.

A Magyar Ifjúság 2012 a magyarországi fiatalok élethelyzetével, életmódjával foglalkozó, az ezredfordulón indult kutatássorozat részét képezi. A gazdag tematikájú kérdőívben szerepet kapott a médiafogyasztás jellegzetességeinek vizsgálata, így a 
médiafogyasztáshoz kapcsolódó párhuzamosság vizsgálatára is sort kerítettünk. A kérdőív tematikája a következő fontosabb kérdésköröket ölelte fel: család, gyermekvállalás; oktatás; munkaerőpiac; külföldi munka és tanulás; politikai attitűd; médiafogyasztás; politika és vallás (önkitöltős); szexualitás és drog (önkitöltős); lakáshelyzet, életkörülmények. A kérdőívben a párhuzamos médiafogyasztásra vonatkozó kérdések a következők voltak:

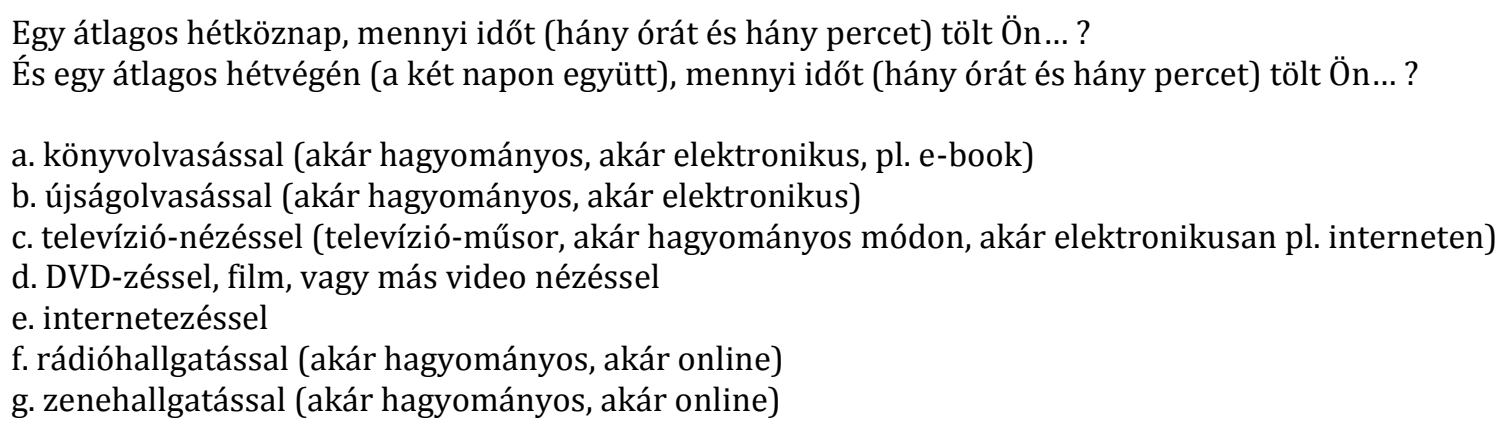

A következőkben a tévézéséhez, internetezéséhez, stb. esetlegesen társuló egyéb tevékenységeiről szeretném kérdezni. Miközben Ön ... az idő mekkora részében végez Ön más tevékenységet is? (a tevékenység jellege nem számít, lehet média, de egyéb is) (az idő nagy részében; az idő felében; az idő kis részében; soha; nem szokott ilyen tevékenységet végezni)

a. könyvet olvas (akár hagyományos, akár elektronikus, pl. e-book)

b. újságot olvas (akár hagyományos, akár elektronikus)

c. televíziót néz (televízió-műsor, akár hagyományos módon, akár elektronikusan pl. interneten)

d. DVD-t, filmet, vagy más videót néz

e. internetezik

f. rádiót hallgat (akár hagyományos, akár online)

g. zenét hallgat (akár hagyományos, akár online)

És miközben Ön a SZÁMÍTÓGÉPEN/INTERNETEN ... az idő mekkora részében végez Ön más tevékenységet is? (a tevékenység jellege nem számít, lehet média, de egyéb is) (az idő nagy részében; az idő felében; az idő kis részében; soha; nem szokott ilyen tevékenységet végezni)

a. online rádiót/ zenét hallgat

b. játszik

c. online tv, vagy más video tartalmakat néz (pl. YouTube, stb.)

d. keres, böngészik

e. cseveg barátaival, ismerőseivel (pl. MSN, Skype, GTalk, Facebook, stb.)

f. e-mailt ír/olvas

g. közösségi oldalakat használ (pl. iWiW, Facebook)

h. híreket, egyéb szöveges tartalmakat olvas

i. dolgozik

j. tanul

A fentiekben bemutatott kutatások célcsoportjukban és az adatfelvételek módszerében kisebb-nagyobb mértékben különböznek egymástól, sőt az egyes kutatások célja rendszerint egészen különböző volt. Mindez egyrészt azt jelenti, hogy egy-két kivételtől 
eltekintve a média multitasking vizsgálata nem volt fő szempont, másrészt a különböző tematikájú kutatások hozzájárulnak a teljesebb kép megrajzolásához. Dolgozatom empirikus eredményeit tehát a fenti, egymással szorosabb-lazább kapcsolatban lévő kutatásokra kívánom alapozni, bemutatva a megváltozó médiafogyasztási és kommunikációs szokásokkal kapcsolatos magyarországi eredményeket, koncentrálva az egyidejű és többcsatornás fogyasztás sajátosságaira.

\subsection{AZ ELEMZÉS ÉS A HIPOTÉZISVIZSGÁLAT MÓDSZEREI}

A fentiekben bemutatott empirikus kutatások eredményeinek feldolgozása során - túl a kvantitatív és kvalitatív módszertani különbségeken - alapvetően három fő célt követtem.

A téma magyar vonatkozású eredményeinek hiányában fontosnak tartom a médiafogyasztás és annak kapcsán a párhuzamos médiafogyasztás alapvető adatsorait, trendjeit bemutatni igazodva az elméleti fejezet végén megfogalmazottakhoz. A helyzetkép és trendek vonatkozásában elsősorban kvantitatív ${ }^{72}$ megközelítéssel dolgozom, erősen támaszkodom a World Internet Project 2001-től rendelkezésre álló adataira. Az egyszerű gyakoriságok, idősorok bemutatása mellett összetettebb indexekkel (pl. média multitasking index), klaszteranalízissel készült tipológiákkal is dolgozom.

A médiafogyasztás, illetve a multitasking jellegzetességeinek bemutatásánál, egy-egy résztéma kibontásánál bemutatok keresztkapcsolatokat, amelyek alapját általában szociodemográfiai háttérváltozók szerinti kereszttáblák, varianciaanalízisek jelentik. A kereszttáblák elemzése során sort kerítek a kapcsolatok szignifikancia vizsgálatára, alternatív magyarázatok kiszűrésére.

Az empirikus adatok elemzése során a doktori munkám szempontjából legfontosabb szerepet a megfogalmazott hipotézisek vizsgálata kapja. A két fő vizsgálati téma és a rendelkezésre álló adatok szerkezete más-más megközelítést kíván, így az életkori, illetve generációs hatások vizsgálatára egy regressziós modell, míg a tevékenységek jellegének vizsgálatának alapjául egy faktoranalízis szolgál. A megfogalmazott

\footnotetext{
${ }^{72}$ A statisztikai elemzések az SPSS programcsomaggal készültek.
} 
hipotézisek vizsgálatában felhasználom a kvalitatív megközelítést is. A fókuszcsoportok eredményeinek elemzésében főként a horizontális megközelítést (egy-egy fókuszcsoportos kutatás során az összes csoport együttes elemzését) alkalmazom, de helyenként a vertikális szempontok is teret kapnak a munkában. A hipotézisek vizsgálatának részletes bemutatása előtt azonban fontos kitérni magának a vizsgálat tárgyának, azaz a párhuzamosság mérhetőségének problematikájára.

\subsubsection{A MULTITASKING MÉRHETŐSÉGÉNEK PROBLEMATIKÁJA}

A fejlett társadalmakra jellemző növekvő szabadidő mennyiségét egyre jobban kitölti a média. Az infokommunikációs eszközök révén lehetővé válik az egyre kevésbé tér- és időfüggő tartalmak fogyasztása és egyéb (jellemzően kommunikációs) tevékenységek végzése. Lengyel (2003) már az ezredforduló utáni években a magyarországi időmérleg adatokon dolgozva megfigyelte, hogy a számítógépezés és ezen belül az internetezés növeli a társas szabadidő volumenét. Az újabb kutatások rámutattak arra, hogy a multitasking figyelembevételével jobban meg lehet érteni az időhasználatot és a különböző tevékenységeket.

Mivel a mindennapi életben végzett tevékenységek közötti figyelemmegosztást nem nagyon lehet objektív eszközökkel mérni így a párhuzamos tevékenységek esetében is csak valamiféle határpont meghatározása válik lehetségessé az egyszerre végezhető tevékenységekről, ami természetesen nagyban függ a tevékenység jellegétől. Az időmérleg-vizsgálatok során alkalmazott naplós módszer régóta alkalmazott, azonban a szimultán tevékenységek megragadására korlátozottan alkalmas. Az emberek mindig is végeztek párhuzamos tevékenységeket, így az olyan esetek nehezen rögzíthetőek a naplóban, mint például ha valaki megkéri a gyermekét, hogy segítsen a házimunkában, hiszen kérdés, hogy ez idő alatt társas interakció, vagy házimunka zajlik-e (melyik az elsődleges és melyik a másodlagos tevékenység). A médiahasználatra irányuló naplózás esetében azonban már több lehetőség van kitérni a média multitaskingra, hiszen a naplóban csak a médiával kapcsolatos tevékenységekre kell koncentrálniuk a kitöltőknek. Vandewater és Lee (2009) szerint a jelenlegi kutatási módszerek nehezen tudják kezelni az egyidejű többszörös médiahasználatot, azonban mindenképpen fontos, hiszen a média multitasking mértéke növekszik. Még az olyan egyszerű kérdésekre is 
nehéz pontos választ kapni, mint például a napi televízió-nézéssel töltött idő, hiszen probléma lehet, hogy ha a tévénézés más szimultán tevékenységgel párosul (pl. számítógépezés) ${ }^{73}$. Ilyen esetekben nehéz meghatározni, hogy ténylegesen mennyi a televízió előtt töltött idő. (Wartella et al., 2009)

Az újabb időmérleg-vizsgálatok (Robinson és Godbey 1997) felfedték az idő mélyítésének ${ }^{74}$ fogalmát, amelyet leginkább a multitasking lehetősége mentén ragadnak meg, a „Csinál Ön mást is?” (Doing anything else?) kérdés segítségével. (Robinson Martin, 2009) Christakis és Zimmerman (2009) szerint a szokásos mérési módszerek kevéssé alkalmasak főleg az ún. multitasking generáció szokásainak követésére. Még azok a naplót alkalmazó technikák is korlátozottan használhatóak, amelyek elsődleges és másodlagos tevékenységek rögzítésére is alkalmasak, hiszen számtalan további aktivitás is előfordulhat, amelyeket nem lehet minden esetben hierarchikus sorrendbe állítani. Robinson és Godbey több problémát is felvet az egyes tevékenységek időtartamára vonatkozó vizsgálatokkal kapcsolatban. Arra a kérdésre, hogy „Hány órát töltesz tévézéssel?" a fiatalok nehezen tudnak átgondolt választ adni, amelyben többek között azt is mérlegelniük kell, hogy a szimultán tevékenységeik között milyen prioritású a tévézés. (Vandewater - Lee, 2009)

A Kaiser Family Foundation (KFF) egyik médiafogyasztásra irányuló vizsgálatában a kutatók a naplóvezetés egy új formáját alkalmazták, amelynek során a válaszadó gyerekeknek a következő kérdésekre kellett válaszolniuk hét napon keresztül minden harminc percben (Roberts et al., 2005):

- Végeztél bármilyen médiához kötődő tevékenységet az elmúlt 15 percben?

- A médiafogyasztás volt a fő tevékenységed?

- Mi mást csináltál?

- Hol voltál?

- Ki volt veled?

E módszer révén a kutatók komplexebb képet kaphattak a gyerekek médiahasználati szokásairól, a médiafogyasztás és más szimultán végzett tevékenységek viszonyáról. Az

\footnotetext{
73Duits (2010) Hendriks és Van Snippenburg (2002) munkái alapján megfogalmazza, hogy a mérések alkalmával számos módszertani probléma merülhet fel, amelyek pontatlan eredményeket hozhatnak, például az önálló naplókészítés és a kérdőívezés során a vizsgált személyek általában csak egy tevékenységről számolnak be egy adott időpontot illetően, ezzel megakadályozva az esetleges multitasking aktivitás feltárását.

${ }^{74}$ Kenyon (2008) javaslata szerint az idő kiszélesítése (broadening of time).
} 
új kutatási módszerek és az új médiaformátumok terjedése újabb kérdéseket vetnek fel. Így például arra számítanak a szakemberek, hogy a gyerekek egyre intenzívebb szimultán médiahasználata hatással lesz a koncentrációs képességekre, amely feltevés tesztelésére az érintett tudományok módszertanának fel kell készülnie. (Anderson Hanson, 2009)

Christakis és Zimmerman (2009) félsikerként értékeli a televízió-nézéssel kapcsolatos kísérleteket is, hiszen a laboratóriumi körülmények közötti tévénézés nem természetes módon hat a televíziós élményekre. Például azok a szülők, akik kísérleti körülmények között vannak összezárva gyermekükkel, interakcióba kerülhetnek olyan módokon is, ahogy otthon, ahol más dolgokra, feladatokra is figyelniük kell, nem kerülnének. Ennek megfelelően a laboratóriumi vizsgálatok nehezen tudják megragadni a valós kontextuális helyzeteket tévénézés közben.

A tévénézés fogalom használata tehát helytelen, hiszen az magában foglalná a többi médium kizárását az adott helyzetben, holott ez valójában nem mindig történik meg. Christakis és Zimmerman (2009) a televíziós élmény (television experience) fogalmat javasolja, ami a televíziózással együtt végzett tevékenységek szélesebb értelmezését teszi lehetővé. A televíziós élmény kutatásakor figyelembe kell venni a tévé által közvetített tartalmat és a tévénézés körülményeit egyaránt.

\section{Média multitasking indexek}

Ophir és munkatársai (2009) a jelenség mérésére egy indexet javasolnak (Media Multitasking Index; $M M I$ ), amely számszerűsíti a szimultán médiafogyasztással töltött időt a teljes médiahasználathoz arányítva ${ }^{75}$.

A média multitasking index 12 különböző médium fogyasztására vonatkozó kérdésen alapul: nyomtatott sajtó, televízió, számítógépen nézhető videó (mint például a YouTube vagy az online televízió), zene, egyéb (zenementes) audio-, video- és számítógépes játékok, telefon és mobiltelefon (hanghívások), azonnali üzenetküldés, SMS, e-mail, böngészés, és egyéb számítógépes alkalmazások (például szövegszerkesztő). A válaszadóknak minden médium esetén meg kellett adniuk, hogy összesen hány órát

75 Vega (2009) ezzel kapcsolatban megjegyzi, hogy a párhuzamos tevékenységek különböző mérőeszközeinek előnyei és hátrányai még nem ismertek. 
töltenek hetente a fogyasztásukkal. Emellett kitöltöttek egy ún. média multitasking mátrixot, amelyben jelezhették, hogy mialatt az adott médiumot elsődlegesként használták, jelen voltak-e más médiumok is, a következők szerint: az idő nagy részében (most of the time), az idő egy részében (some of the time), az idő kisebbik részében ( $a$ little of the time), vagy soha (never) ${ }^{76}$.

$\mathrm{Az}$ index létrehozásához az egyes válaszokhoz numerikus értékeket rendeltek az alábbiak szerint:

- $\quad$ az idő nagy részében $(=1)$,

- $\quad$ az idő egy részében $(=0,67)$,

- az idő kisebbik részében $(=0,33)$,

- $\quad$ vagy soha $(=0)$.

Ezt követően az elsődleges médiumok szerint összesítették a válaszokat, ami alapján kiderült, hogy míg az adott médiumot elsődlegesként használták milyen intenzitással fogyasztottak más médiát is. Tekintettel arra, hogy az egyes elsődlegesként használt médiumok előtt-mellett eltöltött idő nagyon különböző lehet, ezért az index kialakítása során az összesített MMI-t a mennyiséggel súlyozták. A média multitasking index a következőképpen állt össze:

$$
\text { MMI }=\sum_{i=1}^{n} \frac{\mathrm{m}_{\mathrm{i}} \times \mathrm{h}_{\mathrm{i}}}{\mathrm{h}_{\text {total }}}
$$

Ahol $m_{i}$ az adott médium használata során fogyasztott más médiumok száma, a $h_{i}$ a heti mennyiség (óra), amit az adott elsődleges forrással töltöttek a kérdezettek a $h_{\text {total }}$ a teljes médiával (elsődleges médiumokkal) töltött időt jelenti. (Ophir et al., 2009)

Ophir és munkatársai (2009) a 262 egyetemista által kitöltött kérdőív alapján elkészített indexe közel normális eloszlást követett (4,38-as átlaggal és 1,52-es szórással), amely arra utal, hogy a média multitasking nem binomiális eloszlású, azonban mégis meg lehet különböztetni a multitaskinggal inkább és kevésbé élőket.

\footnotetext{
${ }^{76} \mathrm{~A}$ szöveges üzenetek esetében természetesen nem lehet pontosan ezt a metódust követni, ezért Ophir és munkatársai válaszadókat ebben az esetben csak arra kérték, hogy csak jelezzék a más médiumok jelenlétét, míg az index kiszámításánál csak a fennmaradó 11 itemet használták fel.
} 
Az Ophir és munkatársai (2009) által javasolt Media Multitasking Index (MMI) módszertanához részben igazodva - az adott kutatások kereteihez alkalmazkodva kétféle, a párhuzamos fogyasztás mérésére alkalmas indexet dolgoztam ki:

A 2008-as online kutatásunk (ITTK-NRC) adatainak felhasználásával a multitasking gyakoriságát egy olyan összesített indexben foglaltam össze, amely tartalmazza mind az online-offline, mind az online-online multitaskingot. Az index alkotóelemei a következők voltak:

- Rádiót, vagy zenét hallgat számítógépezés, internetezés közben

- Tévét néz számítógépezés, internetezés közben

- Más tevékenységet is végez zene- és/vagy online rádióhallgatás közben

- Más tevékenységet is végez online televízió nézés közben

- Más tevékenységet is végez azonnali üzenetküldőkön keresztül történő csevegés közben

- Más tevékenységet is végez böngészés közben

- Más tevékenységet is végez játék közben

- Más tevékenységet is végez tanulás és/vagy munka közben

- Más tevékenységet is végez E-mail írás/olvasás közben

Ha az eredeti változókat77 egyszerűen összeadjuk, egy olyan változót kapunk, amely a különböző multitasking tevékenységeket összesíti. Az így kapott változót 0-100 közötti értéket felvevő multitasking indexszé $\left(\mathrm{MI}_{0-100}\right)$ konvertálhatjuk. Ahol $m_{i}$ az adott médiumhoz kapcsolódó párhuzamos használatot jelenti.

$$
\mathrm{MI}_{(0-100)}=\sum_{i=1}^{n} \mathrm{~m}_{\mathrm{i}}
$$

A létrehozott index magas értékei gyakori párhuzamos használatra, míg alacsony értékei ennek ellenkezőjére engednek következtetni. Az index várható értéke 51 és szórása 18 indexpontszámot tesz ki. A létrehozott $\mathrm{MI}_{0-100}$ index normalitás tesztje azt mutatja, hogy közel normális eloszlásról beszélhetünk, bár a Khi-statisztika értéke $(18,97)$ kétszerese az 5 százalékos szignifikancia szinten értelmezett küszöbértéknek $(9,45)$, az olyan

\footnotetext{
${ }^{77}$ A kérdőívben alkalmazott pontos kérdésfeltevést lásd a fejezet elején.
} 
robosztus többváltozós modellekben, mint a variancia-analízis alkalmas lehet a függő változó szerepére.

Az Ophir és munkatársai (2009) által készített Media Multitasking Index (MMI) módszertanának az előbbi példánál jobban megfelelve készítettem el a Magyar Ifjúság 2012 adatbázisán is az MMI-t, a következőképpen:

A média multitasking index hét különböző médium fogyasztására vonatkozó kérdésen alapul:

- könyvet olvas (akár hagyományos, akár elektronikus, pl. e-book)

- újságot olvas (akár hagyományos, akár elektronikus)

- televíziót néz (televízió-műsor, akár hagyományos módon, akár elektronikusan pl. interneten)

- DVD-t, filmet, vagy más videót néz

- internetezik

- rádiót hallgat (akár hagyományos, akár online)

- zenét hallgat (akár hagyományos, akár online)

Az index létrehozásához az egyes válaszokhoz numerikus értékeket rendeltem az alábbiak szerint:

- $\quad$ az idő nagy részében $(=1)$,

- $\quad$ az idő felében $(=0,67)$,

- az idő kisebbik részében $(=0,33)$,

- $\quad$ vagy soha $(=0)$.

Ezt követően az elsődleges médiumok szerint összesítettem a válaszokat, ami alapján kiderült, hogy míg az adott médiumot elsődlegesként használták milyen intenzitással fogyasztottak más médiát is. ${ }^{78}$ Tekintettel arra, hogy az egyes elsődlegesként használt médiumok előtt-mellett eltöltött idő nagyon különböző lehet, ezért az index kialakítása során az összesített MMI-t az adott médium fogyasztásának mennyiségével súlyoztam. A média multitasking index a következőképpen állt össze:

\footnotetext{
${ }^{78}$ Ophir és munkatársai az index kialakítása során figyelembe tudták venni az adott médium használata során fogyasztott más médiumok számát is $\left(\mathrm{m}_{\mathrm{i}}\right) . \mathrm{MMI}=\sum_{i=1}^{n} \frac{\mathrm{m}_{\mathrm{i}} \times \mathrm{h}_{\mathrm{i}}}{\mathrm{h}_{\text {total }}}$ Ilyen részletezettségú adatfelvételre a Magyar Ifjúság 2012 esetén nem volt lehetőség ezért a más médiumok száma helyett az index kiszámításához a párhuzamos használat mértékét vettem figyelembe $\left(\mathrm{t}_{\mathrm{i}}\right)$.
} 


$$
\mathrm{MMI}=\sum_{i=1}^{n} \frac{\mathrm{t}_{\mathrm{i}} \times \mathrm{h}_{\mathrm{i}}}{\mathrm{h}_{\text {total }}}
$$

Ahol $t_{i}$ az adott médium használata során a párhuzamos használat mértéke, a $h_{i}$ a heti mennyiség (óra), amit az adott elsődleges forrással töltöttek a kérdezettek a $h_{\text {total }}$ a teljes médiával (elsődleges médiumokkal) töltött időt jelenti.

A létrehozott MMI indexben, hasonlóan a $\mathrm{MI}_{0-100}$ indexhez a magas értékek gyakori párhuzamos használatot, míg alacsony értékek ennek ellenkezőjét jelentik. Az index várható értéke 0,43 és szórása 0,28 indexpontszámot tesz ki. A létrehozott MMI index normalitás tesztje azt mutatja, hogy kevéssé beszélhetünk normális eloszlásról ugyanis az elemszám-érzékeny Khi-statisztika értéke $(389,2)$ sokszorosa az 5 százalékos szignifikancia szinten értelmezett küszöbértéknek $(9,45)$, ami óvatos felhasználásra figyelmeztet.

\subsubsection{A HIPOTÉZISEK VIZSGÁLATÁNAK MÓDSZERTANI MEGFONTOLÁSAI}

A megfogalmazott hipotézisek vizsgálatához (elfogadásához, vagy elvetéséhez) a fentebb részletezett empirikus adatgyűjtéseket különböző mértékben használtam fel, illeszkedve a megfogalmazott hipotézishez. Ahogy a hipotézisekről szóló részben megfogalmaztam a kutatásom során két fő kérdésre keresem a választ:

(RQ1) - a fiatalok médiafogyasztásában tapasztalható jellegzetességek inkább korspecifikusak, vagy generációs jellegüek?

(RQ2) - különböznek-e a szimultán tevékenységek jellegűk szerint (van-e különbség az erőforrás-bővítő és rekreációs tevékenységek között)?

Az egyes kérdésekhez kapcsolódó hipotézisek vizsgálata során eltérő módszertant alkalmaztam az életkori és generációs hatásokra vonatkozó hipotézis vizsgálatában elsősorban a kvantitatív megközelítést használom, míg a tevékenységek jellegére vonatkozó kérdések esetében erősen támaszkodom a vonatkozó fókuszcsoportos eredményeimre is. 


\section{Életkori vagy generációs hatások}

A nemzetközi tapasztalatok és korábbi kutatásaim alapján a médiafogyasztásban megfigyelhető életkori jellegzetességek - miszerint a fiatalabbak médiafogyasztásában az online média számít dominánsnak, illetve a párhuzamos használat is inkább az ifjúság körében jellemző - felvetik azt a kérdést, hogy ezek pusztán életkori sajátosságok, vagy generációs különbségről lehet szó. A kérdéssel kapcsolatosan megfogalmazott fő és alárendelt hipotézisek:

(H1) - A médiafogyasztásban az életkori sajátosságok mellett generációs hatások is érvényesülnek, ami azt jelenti, hogy léteznek olyan, a születési évek alapján meghatározható csoportok (generációk), amelyek médiafogyasztási jellegzetességeiket az évek múlásával is megőrzik.

(H1.1) - A médiafogyasztás mennyisége és a párhuzamos fogyasztás mértéke szerint is jelen vannak a generációs töréspontok;

(H1.2) - a párhuzamos fogyasztás generációs „határai” nem esnek egybe a fogyasztás mennyiségének generációs töréspontjaival.

A fő hipotézis az életkor kitüntetett szerepére utal a médiafogyasztásban, így a multitasking gyakorlásában. A generációs töréspontokra vonatkozó utalás, azt jelenti, hogy vannak a médiafogyasztás mennyiségében és a párhuzamos fogyasztásban is olyan statisztikailag szignifikáns, a születési évjáratokhoz kötődő csoportok, amelyek jelenléte több vizsgálatban is kimutatható. A hipotézis megengedi a különböző generációs töréspontokat, azaz médiafogyasztásban tapasztalható generációs törésponttal nem feltétlenül esnek egybe a multitasking gyakorlásának „határai”, a különböző (X; Y; Z) generációkra vonatkozó szakirodalom alapján ez egyenesen feltételezhető.

A rendelkezésre álló adatok elsősorban az Y és az azt megelőző generációk közötti töréspont(ok) feltárását teszik lehetővé. Az utolsó 14-17 éveseket is felmérő World Internet Project adatfelvétel 2007-ben készült el, amelyben a legfiatalabbak a 1993-ban születettek voltak, a 2009-es adatfelvételben már csak a 18 éveseket és annál idősebbeket kérdezték. A legfiatalabbakat elérő Magyar Ifjúság 2012 adatfelvételében azokat tekintettük 15-29 éves fiatalnak, akik 1983 és 1997 között születtek. A Kutatópont által gondozott rendszeres nagymintás - kifejezetten a médiafogyasztási szokásokra vonatkozó - kérdőíves kutatásából a 2012 őszi hullám adatai érhetőek el, 
azonban mivel a célcsoportot azok alkotják, akik az adatfelvétel időpontjában betöltették a 18. életévüket, ezért a legfiatalabbakat elérő rendelkezésre álló adatok a Magyar Ifjúság 2012-ből származhatnak.

Ahhoz, hogy a médiafogyasztásban generációs töréspontokat határozhassunk meg használhatnánk kizárólagosan a legutóbbi kutatás adatbázisát. Több adatbázis használata azzal indokolható, hogy a generációs-életkori dilemma, ilyen módon alaposabban vizsgálható. Szükségünk van tehát egyfajta idősoros nézőpontra is, ahhoz, hogy megválaszolhassuk azt a kérdést, hogy a megfigyelhető életkori különbségek generációs, vagy életkori sajátosságokra vezethetők vissza. Mindezek alapján a következő adatfelvételekkel dolgozhatunk és a következő évfolyamokat vizsgálhatjuk:

14. táblázat: Az adatfelvételekbe került évfolyamok a különböző kutatásokban

\begin{tabular}{|c|c|c|c|c|c|c|c|c|c|c|c|c|}
\hline & 1997 & 1996 & 1995 & 1994 & 1993 & 1992 & 1991 & 1990 & 1989 & 1988 & 1987 & 1986 \\
\hline WIP2001 & & & & & & & & & & & & \\
\hline WIP2007 & & & & & & & & & & & & \\
\hline LMK2012 & & & & & & & & & & & & \\
\hline MI2012 & & & & & & & & & & & & \\
\hline
\end{tabular}

Az egyes adatbázisokban három különböző szempont szerint is el lehet az elemzést végezni, így:

- a médiafogyasztás mennyisége szerint;

- az egyes médiumok fontosságának (információ és szórakozás) megítélése szerint;

- a multitasking gyakorlása szerint.

Az egyes kutatásokban nem mindegyik szempont elemzésére van lehetőségünk, ugyanis nem minden esetben történt teljes körű lekérdezés. A médiafogyasztás mennyiségére és a médiumok fontosságára vonatkozó kérdésblokkokat mindegyik vizsgálandó adatbázis szinte változatlan formában tartalmazza, azonban multitaskingra vonatkozó kérdések csak a három legutóbbi kérdőívben (WIP2007, LMK2012, Magyar Ifjúság 2012) kaptak helyet.

A megfogalmazott fő hipotézis vizsgálatát alapvetően regressziós modellekkel kívánom elvégezni. Az eljárás alapja lineáris regresszió, ahol a függő változót egy adott média fogyasztásának mennyisége (pl. óra/hét), az egyes médiumok fontosságának megítélése, 
illetve a párhuzamos fogyasztás esetében valamely multitasking index ( $\mathrm{MI}_{0-100}$; $\left.\mathrm{MMI}\right)$ jelenti, míg a független változó az életkor. A hipotézis vizsgálata során kiemelten fontos megvizsgálni, hogy igazolható-e a változók lineáris kapcsolata. Amennyiben jelentős a lineáris kapcsolat az életkor szerepét emelhetjük ki, amennyiben az egyszerű regressziós modellben a linearitás gyenge érdemes megvizsgálni a generációs jelleget.

Ennek vizsgálata szintén a lineáris regresszióelemzés módszertanán alapul, azzal a specifikációval, hogy a független kor változót néhány évenként dummyzuk, azaz kétértékűvé konvertáljuk. A módszer több okból is praktikus, egyrészt lehetőség van referencia kategóriát kialakítani, másrészt a módszer felszínre tudja hozni a függő és független változó közötti nem feltétlenül lineáris kapcsolatot ${ }^{79}$, harmadrészt ezzel az eljárással a regresszió normalitás igényét is sikerülhet csökkenteni. Az ilyen módon megalkotott regressziós modell alapján megmondható, hogy a referenciacsoporthoz képest a többi korcsoport mennyivel és milyen irányban tér el, illetve, hogy ez az eltérés tekinthető-e statisztikailag szignifikánsnak.

A regressziós modellek tehát választ adhatnak arra a kérdésre, hogy van-e lineáris kapcsolat a különböző médiumok fogyasztásának mennyisége, fontosságának megítélése illetve a párhuzamos fogyasztás és az életkor között, tehát van-e életkori sajátosság a médiafogyasztásban? Továbbá az életkori csoportokat alkalmazva független változóként van-e, nem egyetlen egyenessel leírható kapcsolat a médiafogyasztásban. A különböző időpontokban készült kutatások adatbázisainak vizsgálata az ellenőrzésre szolgál, azaz arra, hogy ha egyikben megmutatkozni látszanak generációs jellemzők, azok azonosíthatók-e a másikban is, tehát beszélhetünk-e olyan generációs jellegről, amely az évek múlásával megmarad. Másképpen fogalmazva és másik oldalról megközelítve a kérdést, a különböző időpontokban készült felmérések alkalmazásával kontroll alatt tartható az idő hatása, azaz a teljes társadalmat érintő változások, így a visszaszoruló hagyományos média és a növekvő online média általi jellegzetességek.

\footnotetext{
${ }^{79}$ A lineáris regresszió a nem lineáris kapcsolatokat gyakorta elfedi, lineárisként próbálja magyarázni, az egy- kétévenkénti alminta-képzés azonban apró szakaszokra bontja az egyetlen egyenest (mondhatni kicsi egyenesekre), így képes a nem lineáris kapcsolatokat is jól visszaadni, kiküszöbölve a módszer ezen hiányosságát.
} 


\section{Erőforrás-bővítő és rekreációs tevékenységek}

A nemzetközi kutatások és az ezek kapcsán megfogalmazott elméletek összefoglalásaként javaslatot tettem az egyidejű tevékenységek vizsgálatában a tevékenység jellegének figyelembe vételére, pontosabban a rekreációs és az erőforrásbővítő jellegű tevékenységek elkülönítésére. Kérdésként merül fel, hogy a kognitív rendszert jobban terhelő erőforrás-bővítő feladatok során - mint a munka vagy a tanulás - kevésbé jellemző-e a multitasking, szemben a rekreációs tevékenységekkel. A kérdéshez kapcsolódó fő és kiegészítő hipotézisek:

(H2) - A párhuzamosság mértékének fontos magyarázója a tevékenység jellege: a különböző típusú tevékenységekhez nem azonos intenzitású multitasking társul.

(H2.1) - A rekreációs (média és kommunikációs) tevékenységekben, jelentősebb szerepet kap a multitasking, mint az erőforrás-bövítésben (munka, tanulás);

(H2.2) - a különböző tevékenységek során megfigyelhető multitasking tevékenységek a legtöbbször nem spontán alakulnak ki, hanem tervezettek, tudatosak, az egyén stratégiájától függnek.

A párhuzamosságban tapasztalható különbségek nem csak azt jelenthetik, hogy a hipotézis szerint az erőforrás-bővítő tevékenységek közben kevésbé van jelen más tevékenység, hanem azt is, hogy az egyes tevékenységekhez kapcsolódó párhuzamosságok strukturálisan is különböznek. A tevékenységek jellege szerint eltérő egyidejű használati szokások azt is jelenthetik, hogy a különböző tevékenységek során megfigyelhető multitasking legtöbbször nem spontán alakul ki, hanem tervezett, tudatos, az egyén stratégiájától függ.

A fentebb bemutatott empirikus kutatások közül a hipotézis vizsgálatára egyaránt alkalmasak kvantitatív és kvalitatív megközelítéssel készült kutatások is. A kvantitatív kérdőíves vizsgálatok közül mindenképpen a Magyar Ifjúság 2012 használata tűnik a legalkalmasabbnak, hiszen ebben az esetben szerepeltek kérdések az erőforrás-bővítő tevékenységekkel kapcsolatban. A kérdőíves kutatások többségében szinte kizárólag a média- és kommunikációs multitasking vizsgálatára kerül sor. 
A hipotézis vizsgálata során kevéssé lehet használni a különböző multitasking indexeket, ugyanis azok nem alkalmasak a párhuzamos tevékenységek jelleg szerinti elkülönítésére, továbbá nem szolgálják a hipotézis vizsgálatát a különböző logikai tipológiák sem, hiszen ez esetben meglehetősen önkényes lenne a szerepük. Legalkalmasabbnak tűnik a faktoranalízis használata, amely kifejezetten a látens struktúrák feltárására használható, azaz ha a hipotézisnek megfelelően van különbség a tevékenységek jellegében, akkor az egy faktorelemzés során feltárható.

A tevékenységek jellegében megmutatkozó különbségek vizsgálatára felhasználom a két kvalitatív módszertannal készült kutatást, a Budapesti Corvinus Egyetemen a fiatalok párhuzamos médiafogyasztásáról készült fókuszcsoportos vizsgálatot, illetve a munkahelyi párhuzamos használattal is foglalkozó, szintén fókuszcsoportos kutatás eredményeit. A fókuszcsoportok elemzésében azt a gyakorlatot követem, hogy a tematika főbb pontjai szerint strukturálva összesítem az egyes csoportokban jelenlévő tendenciákat, majd összehasonlítom egymással az egyes csoportokat. A fiatalok párhuzamos médiafogyasztásáról készült fókuszcsoportos vizsgálat során alkalmazott kontrolcsoportos módszer miatt a feldolgozás ennek figyelembevételével készült. Az elemzés során elsősorban az olyan véleményfürtök azonosítására törekszem, amelyek az adott célcsoportban (multitaskingot alkalmazó fiatalok; infokommunikációs munkakörnyezetben dolgozók) rendre megfigyelhetők, ezek alapján kísérelek meg következtetni a párhuzamosság jellegzetességeire az egyes tevékenységek (rekreációs és az erőforrás-bővítő tevékenységek) esetében. 


\section{5. ÚJABB LÉPÉSEK AZ EGYIDEJƯ TÖBBCSATORNÁS KOMMUNIKÁCIÓ ÉS MÉDIAFOGYASZTÁS KUTATÁSÁBAN}

\subsection{MÉDIAFOGYASZTÁSI ÉS PÁRHUZAMOS FOGYASZTÁSI TRENDEK}

A magyarországi tapasztalatok is azt mutatják, hogy a multimédiás tartalmakkal felvértezett internet fokozatosan hódítja meg a médiavilágot, mára megkerülhetetlen, ha információszerzésről van szó, de egyre inkább előtérbe kerül a szórakoztató funkciója is. A médiafogyasztási szerkezetben egyre jelentősebb helyet követelnek meg maguknak az online (és mobil) tartalmak, legyen szó akár szöveg, akár hang, akár hangkép szolgáltatásokról. A trendeket követő háztartásokban a YouTube és a fájlmegosztók már felváltották a televíziót ${ }^{80}$, a rádióknak kedvez az „always on”, míg nyomtatott szövegek sírját talán már meg is ásták az online hírportálok és az e-könyvek.

A médiafogyasztás globális irányai mellett érvényesülnek a régió- és ország-specifikus hatások is. A magyar társadalomról sokáig el lehetett mondani - és gyakorta emlegetik ma is, hogy az átlaghoz képest sokkal magasabb a televízió előtt eltöltött idő, azonban az utóbbi években készült vizsgálatok arról tanúskodnak, hogy már az első öt legtöbbet tévéző nemzet között sem vagyunk ${ }^{81}$. Természetesen a legfrissebb magyar adatok szerinti heti 15 óra tévézés azért a nemzetközi összehasonlításban is jelentékenynek bizonyul. Egyes kutatások alapján azonban meg is lehet kérdőjelezni a magyarok kiemelkedő fogyasztási mennyiségét. Már a Culture Score 2005-ös "Media Habits" Index elnevezésű nemzetközi felmérése - amely 30 ország több mint 30 ezer 13 évesnél idősebb válaszadója megkérdezésével nyert eredményeket tartalmazza - is megállapította, hogy az átlag világpolgár közel 17 órát nézi a televíziót hetente, nyolc órát hallgat rádiót és közel hét órát tölt olvasással, valamint heti kilenc órát a munkájához nem tartozó számítógépezéssel és internetezéssel. A kutatásból kitűnik, hogy a televíziózás tekintetben a „legjobb háromba” várt Magyarország átlag alatt teljesít. A WIP kutatás bár nemzetközi, sok tekintetben különböző stratégiát követnek a

\footnotetext{
${ }^{80}$ A set-top-boxoknak, okostévéknek köszönhetően a televíziós tartalmakat még inkább a fogyasztók szerkesztik.

${ }^{81}$ http://no.nielsen.com/site/documents/Nielsen HowPeopleWatch August2010.pdf
} 
résztvevő országok, leginkább, ami az adatok hozzáférhetőségét illeti. A hozzáférhető legfrissebb adatok szerint Magyarország inkább éllovas, mint a középmezőnybe tartozik. A többi vizsgált médium esetében sem találunk igazán extrém eltéréseket, az alábbi táblázatban szereplő országokkal összehasonlítva úgy tűnik, hogy Magyarország tökéletesen belesimul a globális (európai) médiafogyasztási trendekbe.

15. táblázat: Néhány európai ország médiafogyasztása; óra/hét (Forrás: WIP, 2009)

\begin{tabular}{lcccc}
\hline Médiafogyasztás & Egyesült Királyság & Kanada & Svédország & Magyarország \\
\hline Könyvolvasás & 5 & 5,3 & n.a. & 3,7 \\
\hline Újságolvasás & 3 & 2,6 & 3,4 & 2,8 \\
Rádióhallgatás & 9 & 8,5 & 12,7 & 9,6 \\
TV-nézés & 18 & 10,4 & 11,8 & 15 \\
\hline
\end{tabular}

A médiafogyasztás jellemzőinek vizsgálatára kétségtelenül az egyik legalkalmasabb hazai kutatássorozat a World Internet Project (WIP), amely 2001-től 3-4.000 fő személyes megkérdezésével készül országosan reprezentatív módon. A szokásos médiafogyasztási blokkhoz képest a 2007-es és a 2009-es vizsgálat részletesebben foglalkozott a hagyományos médiával, így alkalmunk nyílik részletesebb vizsgálatokra és megalapozottabb állítások megtételére. A WIP „klasszikus” kérdéssorai foglalkoznak az egyes médiumok fogyasztásának gyakoriságával és mennyiségével, az adott médium szubjektív fontosságával.

\subsubsection{MÉDIAFOGYASZTÁSI TRENDEK, TIPOLÓGIÁK}

A WIP 2009-es adatai szerint a magyar 18 évesnél idősebbekre leginkább a televíziózás jellemző a megkérdezett médiumok közül. Tízből mindössze ketten (18\%) néznek ritkábban, mint hetente televíziót és mindössze a kérdezettek három százaléka marad távol teljesen a televízió-nézéstől. Szinte teljes tükörképe a tévézésnek a videojátékozás, amely a kérdezettek alig ötödére (17\%) jellemző csupán.

A rádióhallgatás a kérdezettek felének (47\%) mindennapi tevékenység, azonban a kérdezettek hetede egyáltalán nem hallgat rádiót. A zenehallgatás ennél kevésbé jellemző a magyar társadalomra, az emberek kétötöde (44\%) egyáltalán nem szokott 
zenét hallgatni, a naponta zenét hallgatók aránya 14 százalékos. Az olvasás inkább újságolvasást, mint könyvolvasást jelent, kétszer annyian maradnak távol a hosszabb elfoglaltságot igénylő könyvektől (37\%) mint az újságoktól (18\%).

15. ábra: Különböző médiumok fogyasztásának gyakorisága (Forrás: WIP,2009)

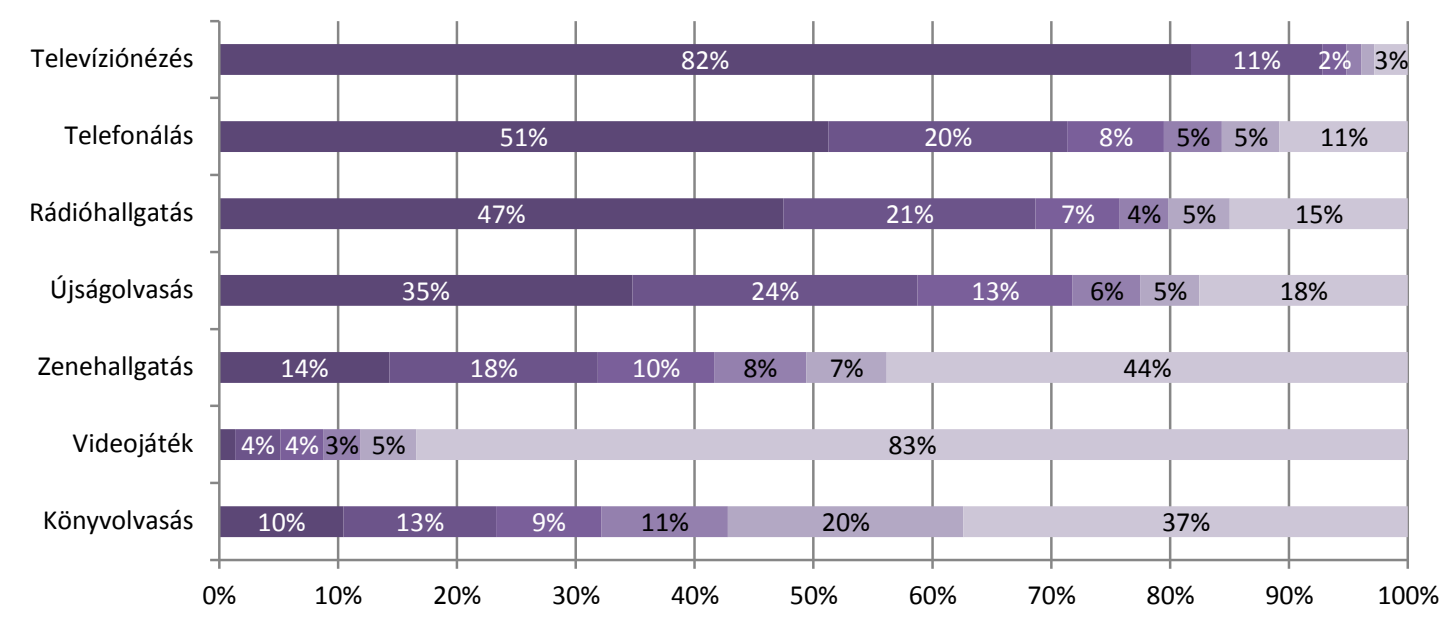

— Naponta, naponta többször $\square$ Hetente többször $\square$ Hetente egyszer $\backsim$ Havonta többször $\square$ Havonta egyszer, vagy ritkábban $\square$ Soha

A WIP 2007-es és 2009-es adatai szerint a kutatásba bevontak átlagosan nagyjából 4045 órát töltenek „médiafogyasztással”, vagyis televízió-nézéssel, rádióhallgatással, újságolvasással, könyvolvasással, telefonálással, valamint videojátékozással. Az internetezés átlagosan további 11-12 órát jelent hetente. Fontos megjegyezni, hogy az internetezők és a nem internetezők alig különböznek egymástól aszerint, hogy összesen mennyi időt szánnak ezekre a tevékenységekre (a nem használók mindössze egy-két órával töltenek többet a hagyományos médiumokkal) ugyanakkor az internetezők emellett átlagosan 11-12 órát interneteznek is, vagyis a két csoport médiafogyasztási struktúrája szinte csak az internethasználatban különbözik egymástól.

A WIP kutatássorozat 2001-től rendelkezésre álló adatait figyelve megállapítható, hogy a médiafogyasztás mennyisége a vizsgált időszakban a legtöbb médium esetében összességében stagnált. A rádióhallgatásban egyértelmű, míg a televízió-nézésben enyhe mennyiségcsökkenést tapasztalhatunk. Mindezek mellett a fogyasztás mennyisége szerint továbbra is megkérdőjelezhetetlen a televízió vezető szerepe. 


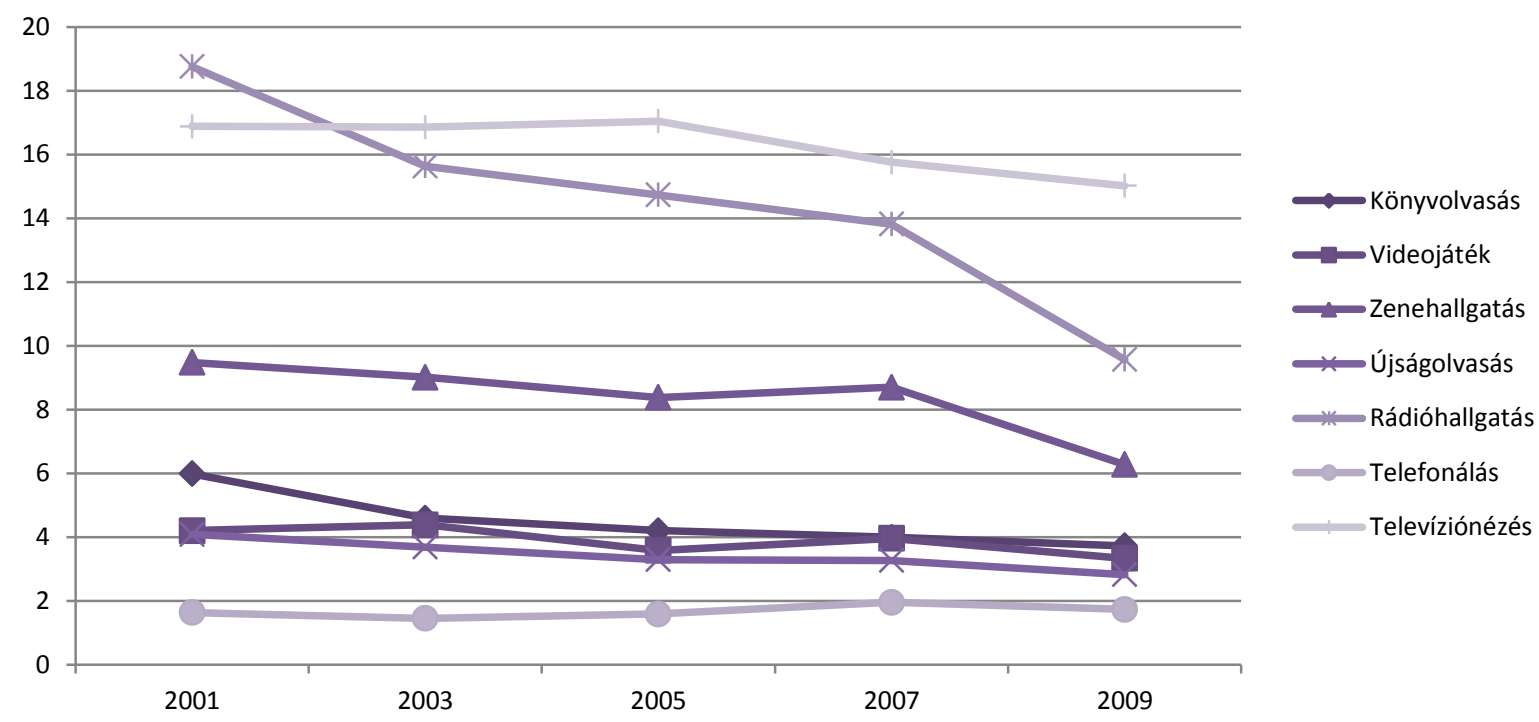

\section{Médiafogyasztási tipológiák}

Korábbi kutatásokban (Pintér, 2004; Pintér - Székely, 2006) foglalkoztunk már a médiafogyasztás (át)alakulásával, megpróbáltunk típusokat alkotni a médiafogyasztás mennyisége szerint. Az egyik legfontosabb eredményként sikerült feltárni a médiafogyasztási szerkezet átalakulásának forrását. Habár a magyar társadalom „médiakosarában” a televízió dominál, ami azt jelenti, hogy a lakosság 70 százaléka a televízió hegemóniájában él, azonban a maradék 30 százalék kitörni látszik a televízió egyeduralmából, ők elsősorban a fiatalok, az internetezők. Mások is megerősítik, hogy van a médiafogyasztóknak egy olyan szegmense, ahol az online felületek válnak dominánssá, amely a televíziót is megelőzi. Bodoky (2007) az Index-olvasók körében készített nem reprezentatív vizsgálata szerint a kérdezettek 90 százaléka számára az internetes hírforrások az elsődlegesek. A hagyományos médiumok elutasításában az internetezéssel töltött idő a legfontosabb magyarázó változó, minél több időt internetezik valaki, annál kevésbé van jelen a hagyományos (elektronikus) média a fogyasztási kosarában. Az Index-olvasókra korlátozódó kutatást részben megismételve a felnőtt magyar népesség körében Bodoky (2009) azt tapasztalta, hogy az elsődlegesen interneten tájékozódó, a hagyományos médiát mellőző „csak online” hírfogyasztók a teljes felnőtt népesség mintegy 11 százalékát teszik ki. 
Pintér (2004) a médiafogyasztási típusok kialakításához a tévénézés, a rádióhallgatás, az újságolvasás, a könyvolvasás, a zenehallgatás és a telefonálás mennyiségét vette figyelembe. Aszerint, hogy hetente átlagosan ki mennyi időt szán a szabadidejéből ezekre a tevékenységekre, öt különböző médiafogyasztói típust különített el a 2001-es és 2002-es adatok alapján. Az alábbi tábla a végleges magközéppontokat mutatja (zárójelben a 2002-es adatok).

16. táblázat: 2001-2002-es médiafogyasztási tipológia (Forrás: Pintér, 2004; WIP, 2001-2002)

\begin{tabular}{lccccc}
\hline & $\begin{array}{c}\text { Visszafogott } \\
\text { média- } \\
\text { fogyasztó }\end{array}$ & $\begin{array}{c}\text { Masszív } \\
\text { tévénéző }\end{array}$ & $\begin{array}{c}\text { Kultúra- } \\
\text { fogyasztó }\end{array}$ & $\begin{array}{c}\text { Kiegyen- } \\
\text { súlyozott } \\
\text { rádiós }\end{array}$ & Médiazabáló \\
\hline Arány 2001 & $52 \%$ & $21 \%$ & $8 \%$ & $18 \%$ & $1 \%$ \\
\hline Arány 2002 & $52 \%$ & $19 \%$ & $10 \%$ & $17 \%$ & $2 \%$ \\
\hline Könyvolvasás & $3,3(3,3)$ & $3,4(3)$ & $5,8(5,8)$ & $3,2(3,1)$ & $8,7(3,4)$ \\
\hline Zenehallgatás & $2,2(2,5)$ & $2,4(2,6)$ & $20,7(25)$ & $2,4(2,8)$ & $45,2(44,7)$ \\
Újságolvasás & $3,3(3,1)$ & $4,0(4)$ & $4,4(4,4)$ & $4,2(3,9)$ & $4,9(5,4)$ \\
\hline Rádióhallgatás & $7,4(6,4)$ & $11(13,5)$ & $10,7(11,9)$ & $46,7(47,2)$ & $37,1(45,9)$ \\
Telefonálás & $1,3(1,2)$ & $0,9(0,9)$ & $2,3(2,3)$ & $1,4(1,6)$ & $3,6(2,4)$ \\
\hline TV-nézés & $11,7(10,5)$ & $35,3(31,7)$ & $13,8(14,6)$ & $17,1(16,8)$ & $20,9(16,9)$ \\
\hline Összesen (óra) & $29,2(27)$ & $57(55,7)$ & $57,7(64)$ & $75(75,4)$ & $120,4(118,7)$ \\
\hline
\end{tabular}

- Visszafogott médiafogyasztó: a magyar társadalom túlnyomó része - több mint a fele - visszafogott médiafogyasztónak tekinthető, aki a kérdezett médiumok mindegyikére átlag alatti időt szán. (Csupán a könyvolvasásban és a telefonálásban nincs igazán különbség az ide tartozók és az átlagos médiafogyasztó között.)

- Masszív tévénéző: ebbe a csoportba tartozók kétszer annyi időt töltenek tévénézéssel, mint az átlag. Televízióra többet (heti 30-35 órát) szánnak az összes többi vizsgált médiumra, egyedül a könyv- és újságolvasásban hasonlítanak a többi csoportra.

- Kultúrafogyasztó: a kultúrafogyasztó típust az jellemzi, hogy tagjai az átlagnál négyszer több időt (közel heti 21 órát) töltenek zenehallgatással és közel másfélszer többet olvasnak, mint az átlagos médiafogyasztó. Jellemző rájuk, hogy az átlaghoz képest jóval kevésbé fogyasztanak hagyományos tömegmédiát. 
- Kiegyensúlyozott rádióhallgató: az ide tartozók médiafogyasztásában a rádióhallgatás dominál, vélhetően ezért hallgatnak jóval kevesebb zenét. Minden más szempontból viszont kiegyensúlyozottnak tűnnek.

- Médiazabálók: a legkisebb, de legintenzívebb médiafogyasztó csoport. Minden típusú médium esetében átlagon felüli a fogyasztásuk, összességében négyszer annyi időt töltenek médiával, mint a visszafogott csoport.

Az idézett elemzés fontos megállapítása, hogy nincs lényeges eltérés a 2001-es és a 2002-es helyzet között, a másik megállapítás, hogy a tévé hegemóniáját sugalló médiafogyasztási kép nem bizonyul a társadalom egészére nézve igaznak. Az ezredfordulón a társadalom egy nem elhanyagolható része - közel harmada - számára a televízió nem jelentett domináns médiaformát (a médiára fordított időnek mindössze csupán a húsz százalékát teszi ki, miközben más médiumok hangsúlyosabb helyet kapnak ugyanezen emberek életében). Ez alapján feltételezhető volt, hogy a hagyományos médiát az internet felől érő kihívás nem egy monolit médiafogyasztási rendszert talál. A részletesebb elemzés rámutatott, hogy elsősorban a fiatalok és az akkor már internetezők különböznek médiafogyasztásuk tekintetében a többségtől. (Pintér, 2004)

A 2009-es adatok elemzése ${ }^{82}$ után csak részben találhatók meg azok a típusok, amelyeket a korábbi vizsgálat feltárt ${ }^{83}$ (egyes csoportok elmosódottabbakká váltak). Az alábbi táblázatra pillantva látszik, hogy mennyire megváltozott a kép az ezredforduló óta, bár az egyes csoportokat domináns értékeik alapján, továbbra is interpretálhatjuk a korábbi jelzőkkel. Az alábbi táblázatra pillantva jól látható a visszafogott médiafogyasztók jelenléte. Ők azok, akik összességében és külön-külön is a legkevesebb médiát fogyasztják és egyben a legnépesebb csoportot alkotják. A legkisebb, de legtöbb médiát fogyasztó „médiazabáló” csoport is jól azonosítható a maga kétszázalékos súlyával és az extrém - a teljes hetet igénybevevő - fogyasztási mennyiségével. Viszonylag karakteresen jelenik meg a masszív tévézők csoportja is, bár a tagok száma jelentősen szűkült és a belső jellemzői is nagyban megváltoztak. Míg az ezredfordulón a leginkább tévéző csoportban az összes médiára fordított idő háromötödét uralta a

\footnotetext{
${ }^{82}$ A 2001-es és 2002-es adatok elemzéséhez hasonlóan a 2009-es adatbázison is klaszteranalízist (KMeans Cluster Analysis) végeztem, az eljárás lényegét tekintve azonos volt a korábban alkalmazotthoz.

${ }^{83}$ Fontos megjegyezni, hogy a 2009-es adatok elemzésénél nem a korábbi klaszterközéppontokból indultam ki, azaz a klaszteranalízis készítése során nem az volt a célom, hogy a korábbi csoportokat reprodukáljam.
} 
televízió, addig ma valamivel több, mint felét. A többi csoportot is figyelembe véve mind mennyiségében, mind a belső struktúra arányaiban lényegesen visszaesett a televízió szerepe. A legkevésbé azonosítható csoportosulás a kultúrafogyasztóké, akiket talán nem is illethetünk ezen a néven, hiszen lényegesen nagyobb csoportról van szó, másrészt, a kultúra (zene, könyv) előtérbe helyezésére sem lehet egyértelműen következtetni.

17. táblázat: 2009-es „hagyományos” médiafogyasztási tipológia (Forrás: WIP, 2009)

\begin{tabular}{lccccc}
\hline & $\begin{array}{c}\text { Visszafogott } \\
\text { médiafogyasztó }\end{array}$ & $\begin{array}{c}\text { Média- } \\
\text { zabáló }\end{array}$ & $\begin{array}{c}\text { Masszív } \\
\text { tévénéző }\end{array}$ & $\begin{array}{c}\text { Kiegyensúlyozott } \\
\text { rádiós }\end{array}$ & $\begin{array}{c}\text { “Kultúra- } \\
\text { fogyasztó" }\end{array}$ \\
\hline Arány & $46 \%$ & $2 \%$ & $12 \%$ & $8 \%$ & $32 \%$ \\
\hline Könyvolvasás & 2,5 & 7,0 & 6,3 & 6,3 & 4,1 \\
Zenehallgatás & 3,1 & 55,3 & 6,9 & 16,1 & 7,0 \\
\hline Újságolvasás & 1,7 & 7,4 & 3,4 & 4,6 & 3,5 \\
Rádióhallgatás & 3,5 & 45,4 & 10,5 & 40,2 & 9,2 \\
Telefonálás & 1,5 & 3,4 & 1,7 & 2,3 & 2,0 \\
TV-nézés & 5,3 & 50,4 & 36,2 & 17,1 & 18,1 \\
\hline Összesen (óra) & 18,0 & 168,9 & 65,0 & 86,6 & 44,2 \\
\hline
\end{tabular}

A WIP kutatások kezdetek óta az internetezést, mint feltörekvő médiumot állították központba és aszerint vizsgálták a hagyományos médiafogyasztást. Amennyiben a fent bemutatott hagyományos médiafogyasztási struktúrába beemeljük az internetet is azt találjuk, hogy alapvetően megváltoztatja a belső viszonyokat, egyrészt letisztulnak csoportok, jobban hasonlítva az eredeti tipológiához, másrészt a korábban kultúrafogyasztónak címkézett csoportosulásban egy másik tényező - az internet játssza a főszerepet.

18. táblázat: 2009-es, internettel bővített médiafogyasztási tipológia (Forrás: WIP, 2009)

\begin{tabular}{lccccc}
\hline & Rádióhallgató & Netpolgár & Média-zabáló & $\begin{array}{c}\text { Visszafogott } \\
\text { médiafogyasztó }\end{array}$ & $\begin{array}{c}\text { Masszív } \\
\text { tévénéző }\end{array}$ \\
\hline Arány & $9 \%$ & $23 \%$ & $8 \%$ & $52 \%$ & $8 \%$ \\
\hline Könyvolvasás & 5,6 & 4,1 & 6,4 & 2,9 & 5,8 \\
\hline Zenehallgatás & 9,2 & 5,1 & 35,2 & 4,0 & 8,4 \\
\hline Újságolvasás & 3,7 & 3,4 & 5,2 & 2,1 & 3,4 \\
\hline Rádióhallgatás & 48,2 & 8,7 & 24,1 & 4,6 & 10,7 \\
\hline Telefonálás & 2,9 & 1,5 & 2,9 & 1,6 & 1,7 \\
TV-nézés & 19,2 & 20,4 & 22,5 & 7,4 & 44,2 \\
\hline Internetezés & 3,7 & 41,2 & 14,6 & 7,6 & 10,4 \\
\hline Összesen (óra) & 92,7 & 84,4 & 110,9 & 30,3 & 84,6 \\
\hline
\end{tabular}


- Visszafogott médiafogyasztó (52\%): minden területen, kivéve az internetet a legalacsonyabb fogyasztási mennyiségekkel rendelkezik. Az internet esetében a fogyasztása átlag alatti. Összes médiafogyasztása átlagosan heti 30 óra.

- Masszív tévénéző (8\%): továbbra is igaz a csoportra, hogy televízióra többet szán, mint az összes többi vizsgált médiumra együtt.

- Netpolgár (23\%): a kultúrafogyasztó típus helyett lép be a tipológiába, azonban az említettre nem hasonlít semmiben. A médiafogyasztását az internet dominanciája jellemzi, közel a teljes médiára fordított idő felét internetezéssel tölti.

- Rádióhallgató (9\%): az ide tartozók médiafogyasztásában eredetileg a rádióhallgatás, dominál. Az internet jelenléte ugyanakkor felborítja az egyensúlyt, láthatóan a csoportban az átlaghoz képest jóval kevesebbet interneteznek.

- Médiazabálók (8\%): továbbra is jelen van egy mennyiségében kiemelkedően sok médiát fogyasztó csoport. Tagjainak minden típusú médium esetében átlagon felüli a fogyasztásuk. Összességében háromszor-négyszer annyi időt töltenek médiával, mint a visszafogott csoport.

\section{Az egyes médiumok szubjektív fontosságának megítélése}

A WIP-kutatás már a kezdetektől foglalkozik az egyes médiumok fontosságának megítélésével, amelyet hagyományosan két dimenzióban: információforrásként és a szórakozás forrásaként ítélhették meg a kérdezettek. Összességében megállapítható, hogy - hasonlóan a korábbi évek eredményeihez - a legfontosabb információ és szórakozási forrás a televízió vezető szerepe sok tekintetben megkérdőjelezhetetlen. 


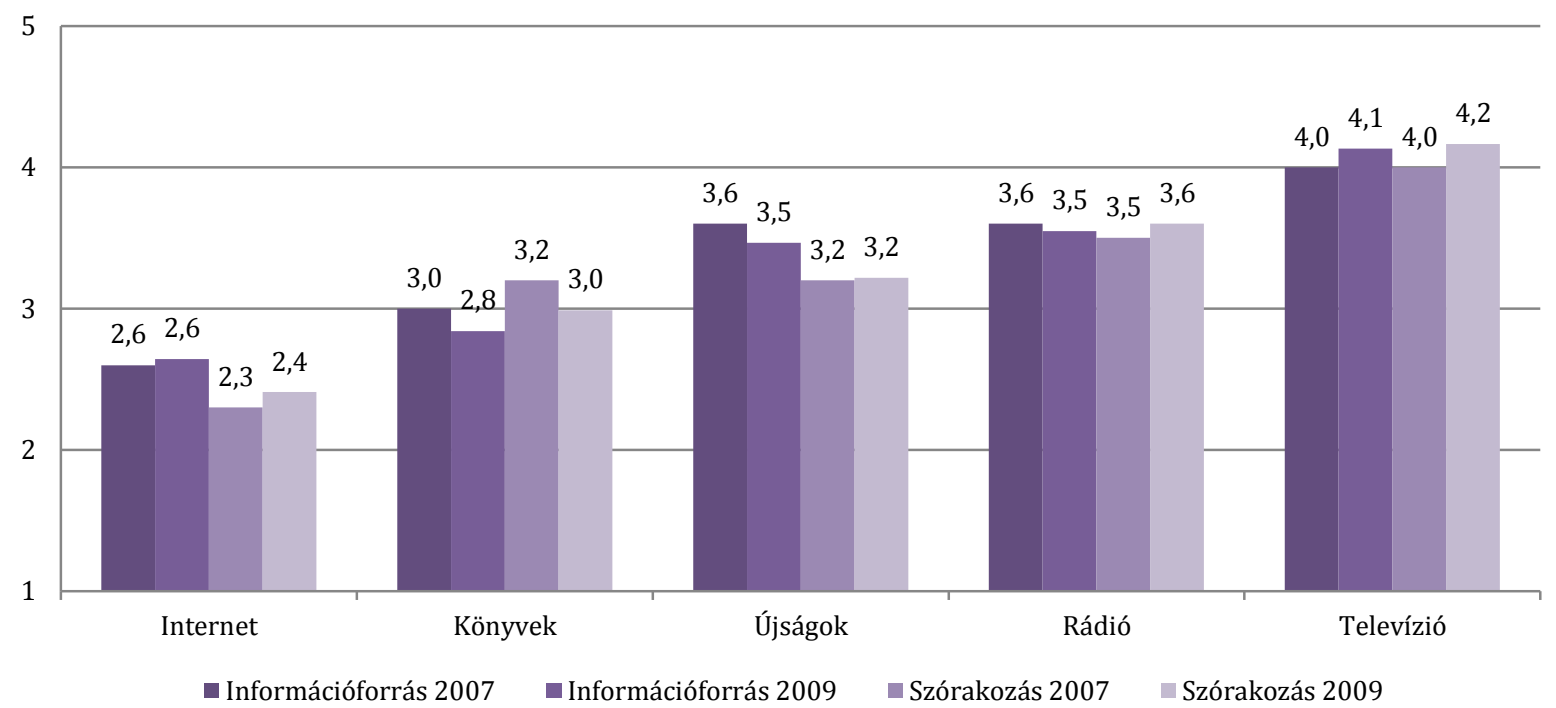

Mindazonáltal, ha internetezés szerint vizsgálódunk azt találjuk, hogy az internetezők számára már fontosabb a világháló, mint a televízió. A Nemzeti Hírközlési Hatóság felmérése is hasonló eredményre jut, eszerint „a tévé mint a szórakozás, a kikapcsolódás eszköze az internetezők körében háttérbe szorul. Az aktualitásokról való tájékozódás terén azonos jelentőségű hírforrás a számukra az internet és a hagyományos média. Az internet a kapcsolattartásban is elérte azt a jelentőséget, amellyel fő riválisa, a telefon bír". (NHH, 2009, pp:39)

Az Ipsos egy 23 országra kiterjedő felmérése szerint (Global Advisor), amelyben 24 ezer internetezőt kérdeztek internetezési és tévézési szokásairól megállapítható, hogy országoktól függetlenül az internetezők fele többet van online, mint amennyit tévét néz. A legalacsonyabb (55\%) arányt Belgiumban, a legmagasabbat (89\%) Kínában mérték, míg Magyarország a középmezőnyben szerepel, valamivel meghaladva az átlagot. Az első ránézésre furcsa adatokat magyarázhatja az internetpenetráció, a sűrűn behálózott országokban sok alkalmi netező kapcsolódik a világhálóhoz, míg a kevesebb internetezővel bíró országokban nagyobb súlyt képviselnek az internetet munkaeszköznek (is) használó profik. (Ipsos, 2010)

Ha a WIP adatbázison ún. faktorelemzés segítségével megkísérelünk - mintegy a válaszadók fejébe nézve - megtalálni azt a látens struktúrát, amely mentén formálódik

${ }^{84} \mathrm{~A}$ fontosságot a válaszadók egy ötfokozatú skálán határozhatták meg, ahol az „1” érték jelentette, hogy egyáltalán nem fontos, míg az „5”-ös, hogy nagyon fontos. 
az egyes információforrás szempontjából fontos médiumok megítélése, azt találhatjuk, hogy két faktorba rendeződnek az egyes médiumok megítélései. Az egyik faktor internet és könyv központú, a másik esetében a televízió és a rádió dominál, míg a napilapok és a folyóiratok mindkét faktorban szerepet játszanak. Ez azt jelenti, hogy akik az internetet az átlagnál fontosabbnak tekintik, azok a könyvekkel kapcsolatban is így éreznek és fordítva. Az ekként gondolkodók elkülönülnek azoktól, akik az átlagnál fontosabbnak tekintik a televíziót, illetve a rádiót. Ugyanezt a logikát követe egy másik módszerrel (klaszteranalízis) azt is megállapíthatjuk, hogy a válaszadók többsége (60\%) inkább az utóbbi csoportba tartozik.

Az egyes médiumok-technológiák fontosságát az Nemzeti Hírközlési Hatóság (NHH) egy másik módszerrel vizsgálta. Kutatóik azt a kérdést tették fel, hogy melyek a legnélkülözhetetlenebb távközlési szolgáltatások. A kérdezettek többsége (62\%) a mobiltelefont nélkülözhetetlennek tartja és fontos a televízió is, míg az internet és a vezetékes telefon közepes fontosságú, a mobilinternet (2009-ben) a többség számára felesleges.

18. ábra: Távközlési szolgáltatásokhoz kapcsolódó igényszintek (Forrás: NHH, 2009)

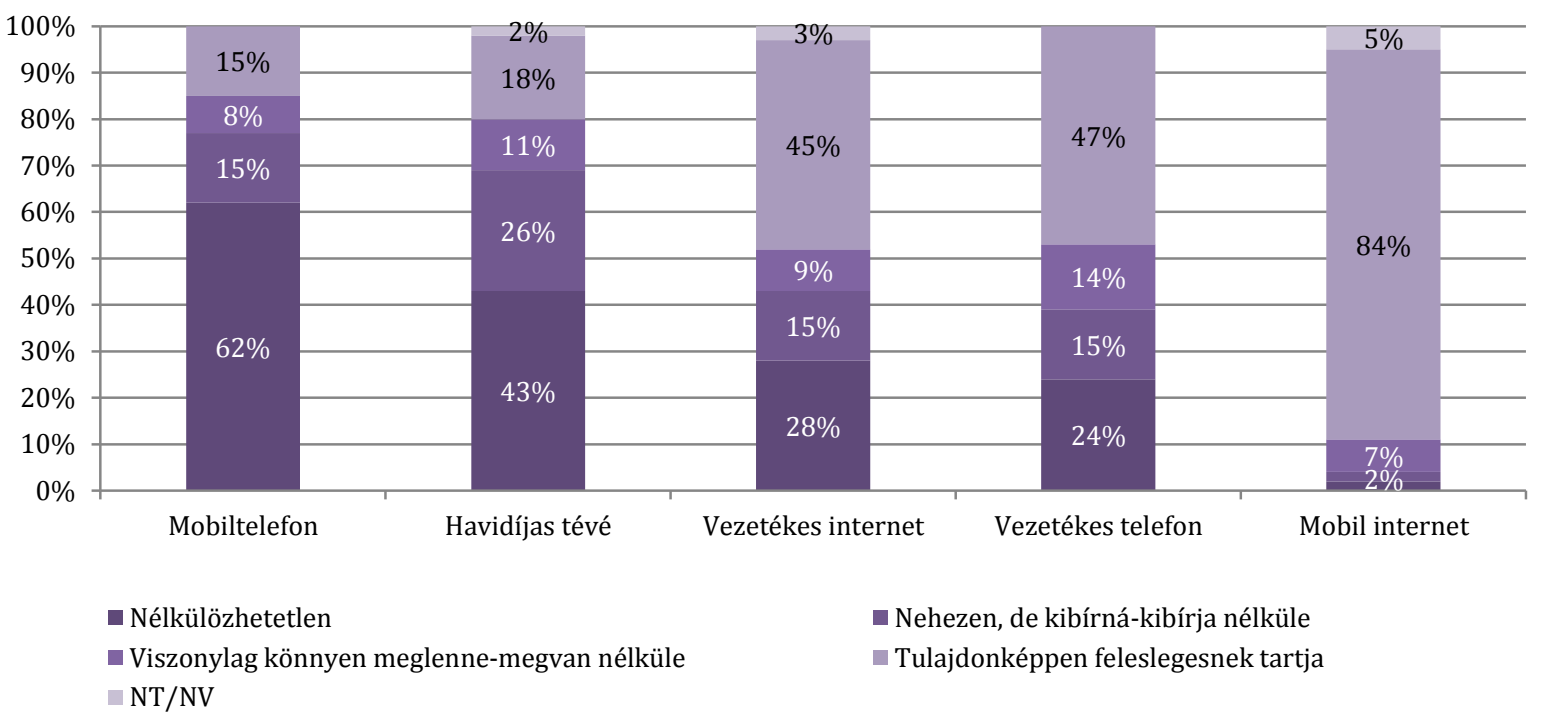




\subsubsection{MULTITASKING TRENDEK}

A WIP átfogó statisztikái arra utalnak, hogy az internetező társadalom majd kétharmada szokott internetezés közben másfajta médiát is fogyasztani. A 2007-es és 2009-es adatok - figyelembe véve, hogy a legfiatalabb korosztályok (15-17 évesek) kimaradtak a legfrissebb felmérésből - meglehetős hasonlóságot mutatnak. Találunk egy szúkebb (2030\%) gyakori multitaskingot űző csoportot és egy ritkább párhuzamos médiafogyasztó csoportot (30-40\%), illetve egy hasonló méretű a multitaskingtól távolmaradó csoportot.

19. ábra: Internetezés közben más médiumok fogyasztásának gyakorisága (Forrás: WIP, 2009)

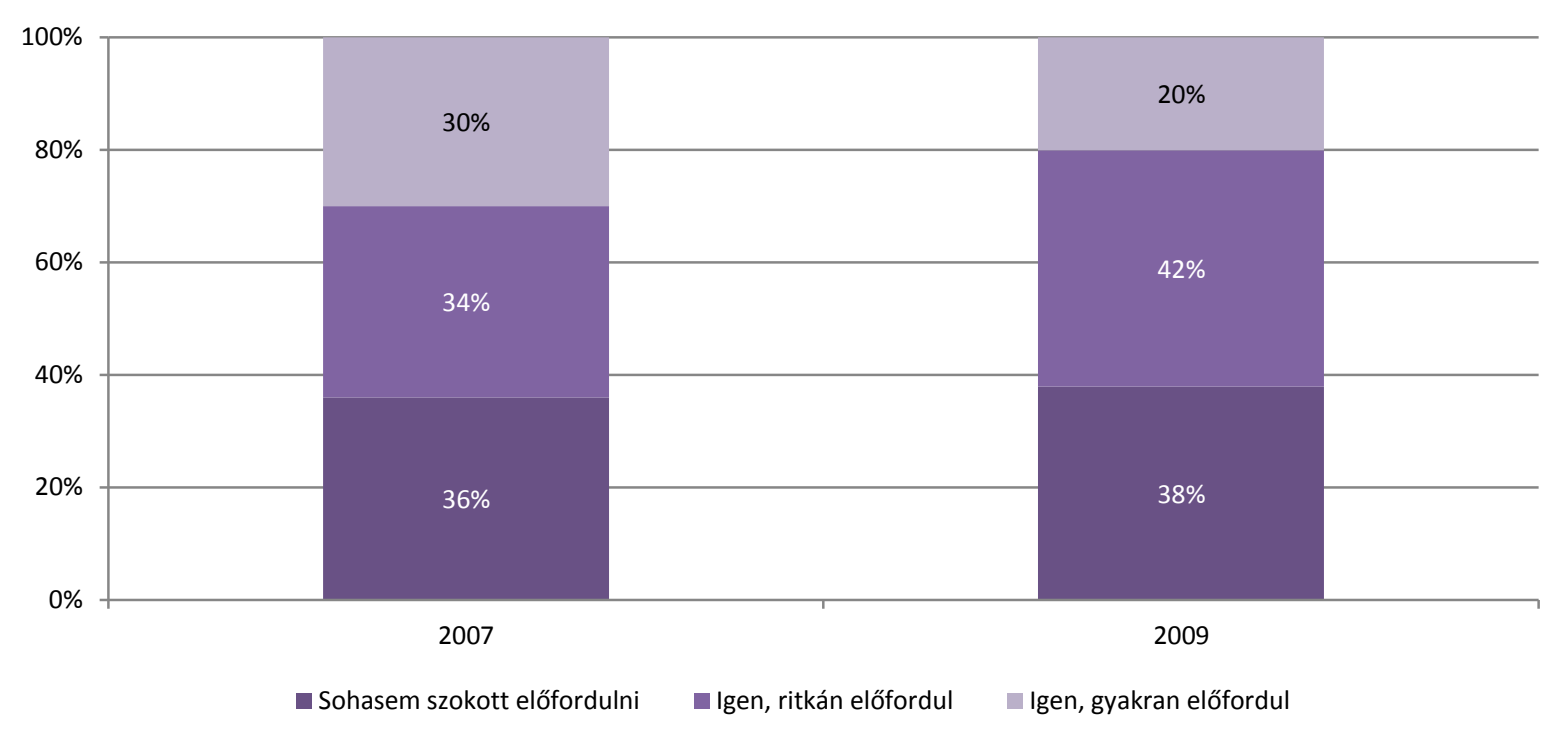

A médiafogyasztás mennyiségét a multitasking gyakorlása szerint vizsgálva a fogyasztás mennyiségében szignifikáns különbségeket találunk elsősorban a zenehallgatás, a telefonálás és az internetezés tekintetében. Az internetezés közbeni multitasking gyakori alkalmazói átlagosan közel 13 órát hallgatnak zenét, 15 órát interneteznek és több mint három $(3,2)$ órát telefonálnak hetente, szemben a multitaskingot nem gyakorlók heti 7-8 órás zenehallgatásával, internetezésével és valamivel több mint kétórás $(2,3)$ telefonálásával. További szignifikáns, bár nem ennyire erős kapcsolatot mutat a könyvolvasás és a videojátékozás mennyisége, ugyanakkor újságolvasás és rádióhallgatás tekintetében nem találunk különbséget a 2007-es adatok alapján. 
19. táblázat: Médiafogyasztás mennyisége multitasking gyakorlata szerint (N=1338; WIP, 2007)

\begin{tabular}{lcccc}
\hline & Gyakran előfordul & Néha előfordul & Soha nem szokott & Totál \\
\hline Internetezés & 14,9 & 10,6 & 7,5 & 10,8 \\
\hline Könyvolvasás & 4,3 & 3,7 & 4,7 & 4,2 \\
Videojáték & 4,8 & 4,5 & 2,9 & 4,2 \\
\hline Zenehallgatás & 12,6 & 8,7 & 7,3 & 9,5 \\
Újságolvasás & 3,0 & 2,9 & 3,2 & 3,0 \\
\hline Rádióhallgatás & 13,3 & 12,0 & 13,2 & 12,8 \\
Telefonálás & 3,2 & 2,8 & 2,3 & 2,8 \\
\hline TV-nézés & 13,0 & 12,7 & 13,6 & 13,1 \\
\hline
\end{tabular}

A hazai nagyobb felmérések a média multitasking jelenségét általában csak jelzik, nem próbálják azt mélyebben megismerni. Ezt a hiányt pótolandó készítettünk az Információs Társadalom- és Trendkutató Központ (ITTK) valamint az NRC Piackutató együttműködésében felmérést 2008-ban, amit részben megismételtünk 2012-ben a Kutatópont keretein belül. A kutatás módszere online kérdőíves adatfelvétel volt, amelynek során 2008-ban 100015 éves és annál idősebb (2012-ben 100018 éves és annál idősebb) internetezőt kérdeztünk meg, akik főbb szociodemográfiai jellemzőik alapján jól reprezentálják a 15 (2012-ben 18) éves és annál idősebb magyarországi internetezők csoportját.

A média multitasking tevékenységeit az elméleti fejezetben is megemlített felosztás szerint két részre bontottuk egy online-offline és egy online-online csoportra. Az előbbi esetében arra voltunk kíváncsiak, hogy a számítógépezés, internetezés mellett hagyományos módon milyen gyakori a televízió nézés és a rádió-, vagy zenehallgatás. Az adatokat áttanulmányozva a nagymintás, internetet nem használókat is tartalmazó kutatások eredményeit megerősítve fő megállapításunk az lehet, hogy az online-offline multitasking a magyar internetezők többségére jellemző. Csupán a kérdezettek kétötöde (38\%) nem szokott egyáltalán (hagyományos módón) tévét nézni számítógépes, internetes tevékenységei közben, míg mindössze egyötödükre (22\%) jellemző, hogy ilyenkor sohasem hallgat rádiót, vagy zenét. A kérdőívben egy ötfokozatú skálával dolgoztunk, amelynek átlagai is (2,5 és 2,9) arról tájékoztatnak, hogy a multitasking jellemző médiafogyasztási forma a 15 évnél idősebb internetezők között. 
20. ábra: Számítógépezés, internetezés közbeni hagyományos médiafogyasztás gyakorisága (N=1000; Forrás: ITTKNRC, 2008)

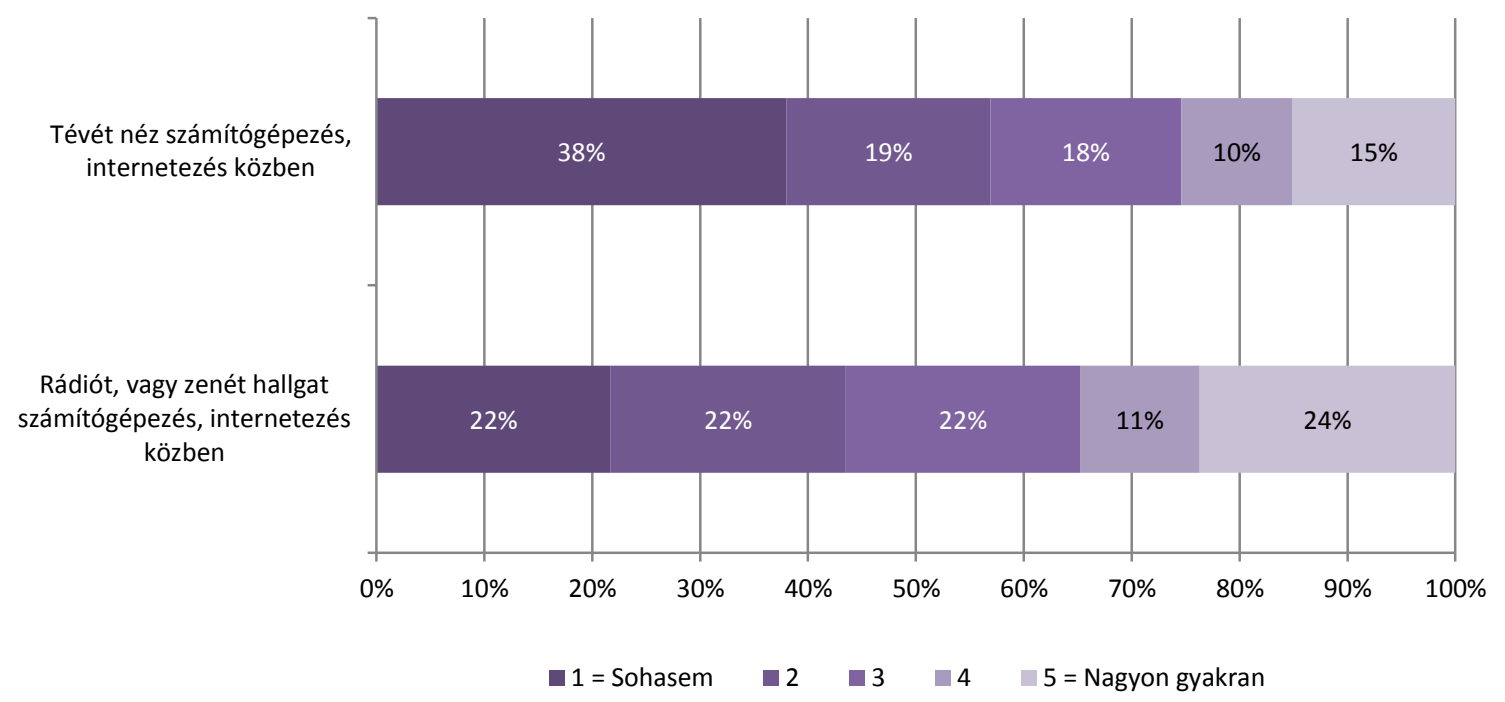

Megjegyzendő, hogy a két vizsgált multitasking tevékenység között szignifikáns, bár gyenge korreláció van (a Pearson féle korrelációs együttható 0,2), ami azt jelenti, hogy nem egy általános média multitasking viselkedéssel van dolgunk, azaz pl.: aki számítógépezés, internetezés közben gyakorta tévézik nem feltétlenül szokott tévézés helyett rádiót vagy zenét hallgatni. Vélhetően az egyéni médiafogyasztási jellemzőkhöz kötődő sokkal összetettebb viszonyokkal kell számolnunk, amelyek megvilágításához közelebb kerülhetünk a gyakorta használt szociodemográfiai jellemzők szerinti felosztással.

Megkíséreltünk némi objektivitást is vinni a jórészt erősen szubjektív, megítélésekre hagyatkozó mérésbe, ezért arra kértük a kérdőív kitöltőit, hogy mondják el, hogy mialatt a kérdőívet kitöltötték milyen tevékenységeket folytattak még. A kérdezett tevékenységeket két részre választottuk online világhoz kötődő tevékenységekre és olyanokra, amelyek függetlenek a számítógéptől.

Az offline tevékenységek közül leggyakrabban a tévézést említették a kérdezettek, minden negyedik (27\%) kitöltő megemlítette a televíziót, minden ötödik (19\%) telefonált, minden tízedik kérdezett hallgatott zenét (13\%), vagy rádiót (10\%), esetleg tanult, vagy dolgozott. Az olyan tevékenységek, mint az újságolvasás, DVD-zés, könyvolvasás már csak elvétve fordulnak elő. 
21. ábra: Végzett-e más NEM a számítógéphez kötődő tevékenységet miközben a kérdőívet kitöltötte? (N=1000; Forrás: ITTK-NRC, 2008)

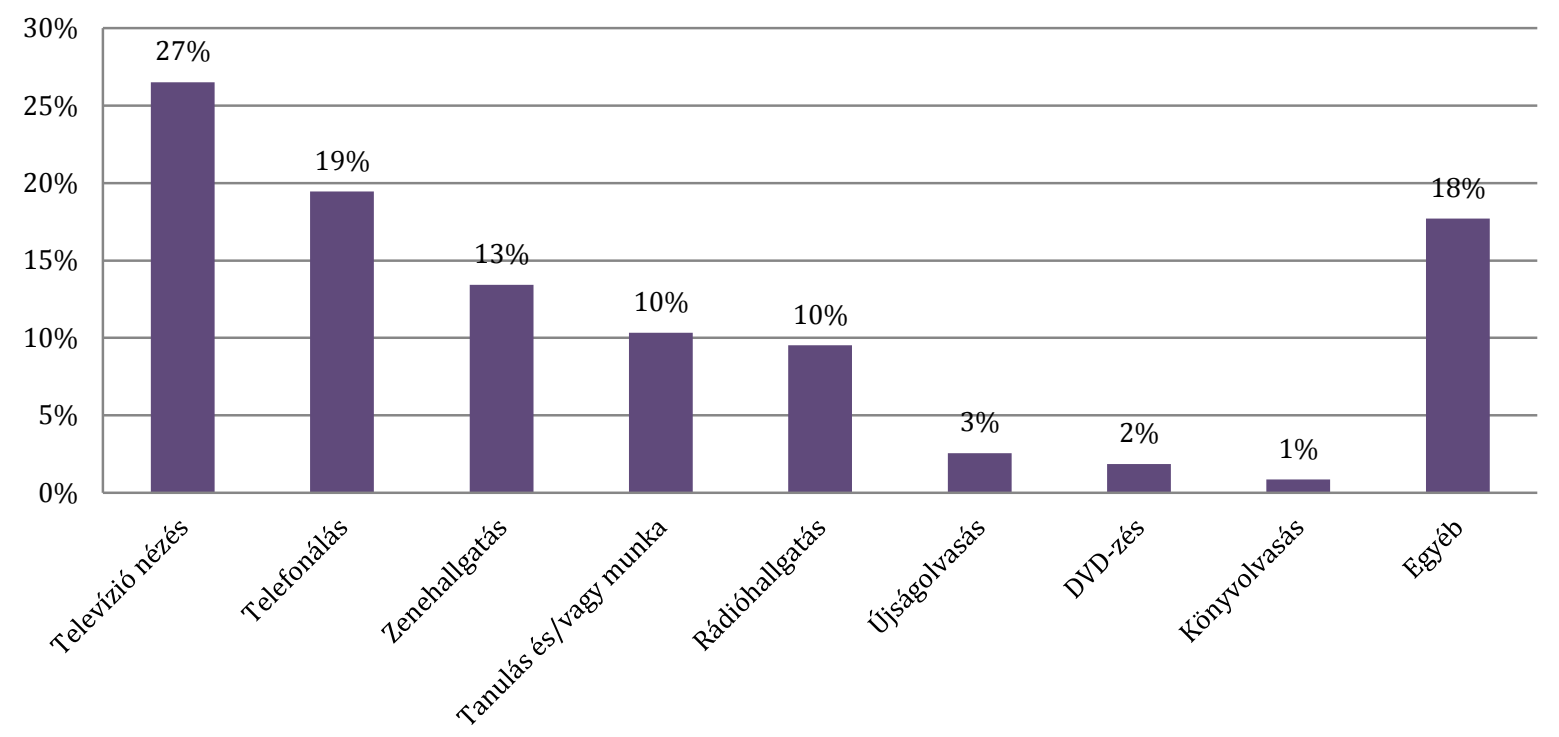

$\mathrm{Az}$ egyidejű tevékenységeket minden bizonnyal elősegíti a számítógép képessége a többfeladatos feldolgozásra, a felhasználó számára egyszerű és a technológia lehetővé teszi, hogy egyszerre több alkalmazás fusson a számítógépeken. Ezt a lehetőséget sokan ki is használják, a kérdőívet kitöltők közel harmada (31\%) küldött, vagy fogadott emaileket, szinte ugyanennyien (29\%) hallgattak zenét. Minden negyedik (23\%) megkérdezett azonnali üzenetküldőkön csevegett és minden ötödik (19\%) böngészte közben a világhálót. 


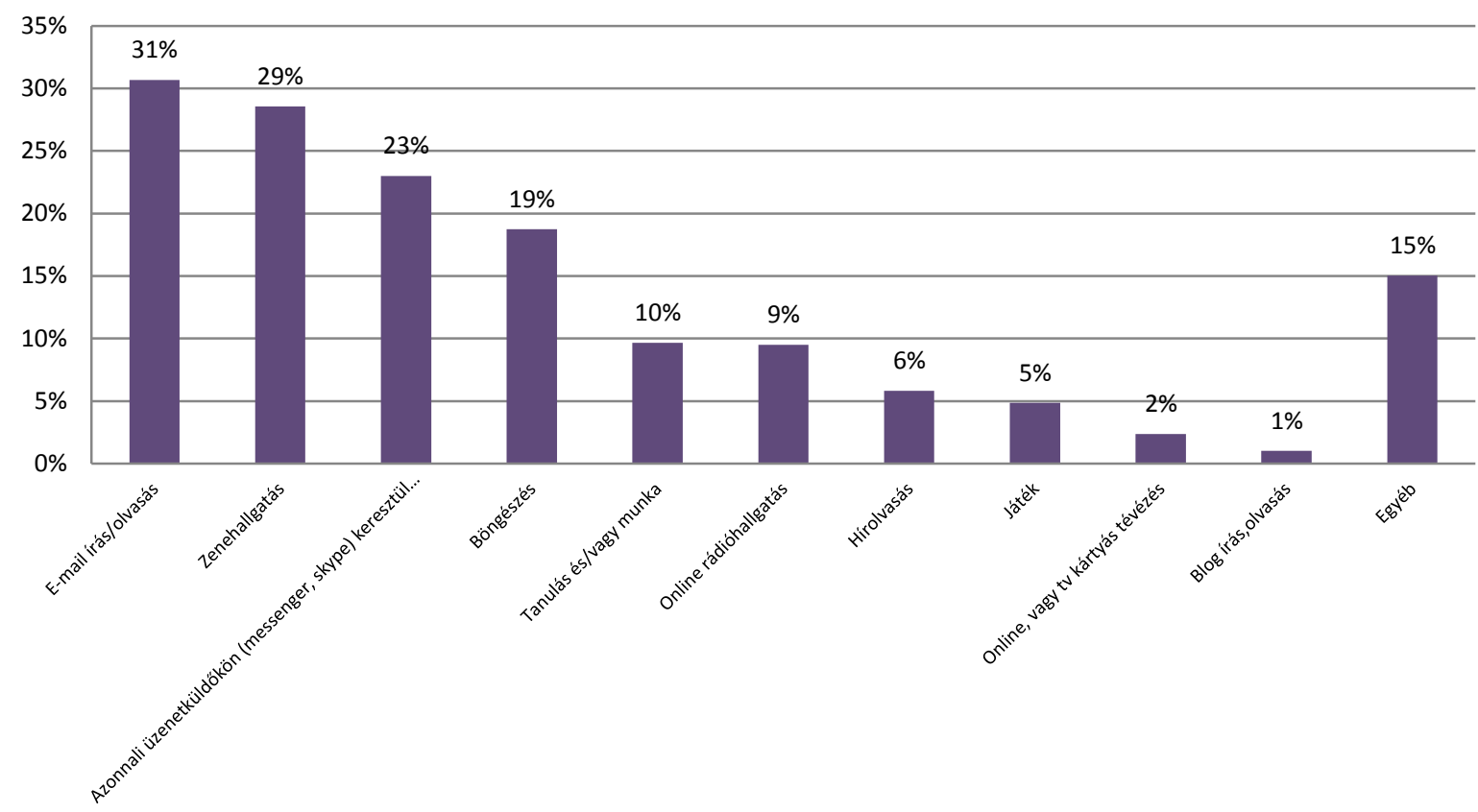

Figyelemreméltó, hogy a megadott tevékenységek közül mindösszesen a kérdezettek hat százaléka nem végzett egyet sem a kérdőív kitöltése alatt. Jellemzően 1-3 tevékenységet társítottak a kérdőívkitöltéshez és mindösszesen egyötödük (19\%) foglalkozott négy vagy annál több dologgal. A 2008-as felvételt részben megismételve 2012-ben a 18 éves, vagy annál idősebb korosztályra mértékben eltérő, de sorrendben nagyon hasonló eredményeket figyelhetünk meg.

Az ifjúsági csoportok egyidejü, többcsatornás kommunikációs és médiafogyasztási szokásainak mélyebb vizsgálatára ad lehetőséget a legfrissebb nagymintás ifjúságkutatás (Magyar Ifjúság 2012), amely a Kutatópont berkeiben zajlott 2012 végén. Az eredmények alapján elmondható, hogy a 15-29 éves magyar fiatalok, amennyiben folytatnak bizonyos médiatevékenységeket nagyrészüknél - ha csupán időközönként is, de - jelen van a multitasking.

Ezekben az adatokban egyedül a televízió szerepe lehet meglepő, ugyanis a nemzetközi kutatások megfigyelései alapján a legintenzívebben megosztott tevékenységek egyike, a tévézés a Magyar Ifjúság 2012 eredményei szerint azonban a televízió inkább a középmezőnyben foglal helyet. Egyfajta érzékszervi sorrendet is láthatunk megjelenni, ahol a párhuzamosság inkább a halláshoz (zene, rádió), míg az egycsatornás fogyasztás 
inkább a látáshoz kötődik (olvasás), a kevert tartalmak, amelyek a látás és a hallás érzékeit is stimulálják (videók, internet) ezek között helyezkednek el.

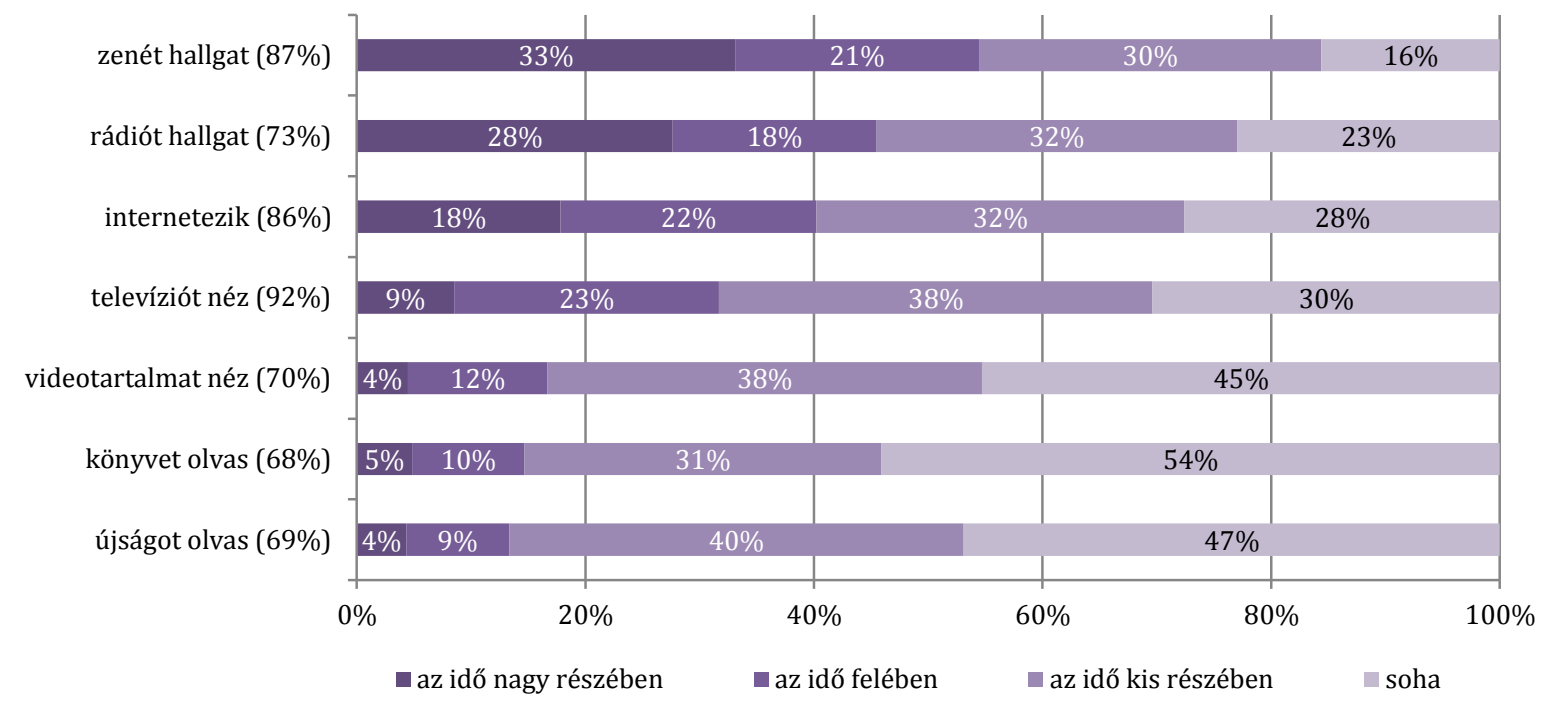

* zárójelben az adott tevékenységet folytatók aránya

A fentiekben tapasztaltak megjelennek az online, nem kizárólag média típusú tevékenységek esetében is. Az online tevékenységek közül leggyakrabban a zene- és online rádióhallgatásban találunk párhuzamosságot, míg a médiához szorosan kapcsolódó tevékenységek közül a szöveges tartalmak fogyasztásában legkevésbé. Kifejezetten érdekes a közösségi oldalak használata és az online csevegés mellett megjelenő halmozott fogyasztás, amelynek mélyebb vizsgálata kapcsolódhat az írásbeli szóbeliség85 kutatási területéhez.

Azt is érdemes megfigyelnünk, hogy az online környezet nem feltétlenül jelent intenzívebb multitaskingot, hiszen a számítógéphez, internethez kötődő videotartalmak fogyasztása mellett jelenlévő más tevékenységek markánsan nem különböznek az összes videotartalom esetében tapasztalthoz képest. Mindez, figyelembe véve a multitasking terjedését azt jelentheti, hogy az egyidejű tevékenységek gyakorisága az offline viszonyok között is növekszik.

${ }^{85} \mathrm{Az}$ online környezet írott nyelve gyakran - a közösségi oldalakon különösen - a szóbeliség jellegét hordozza. 


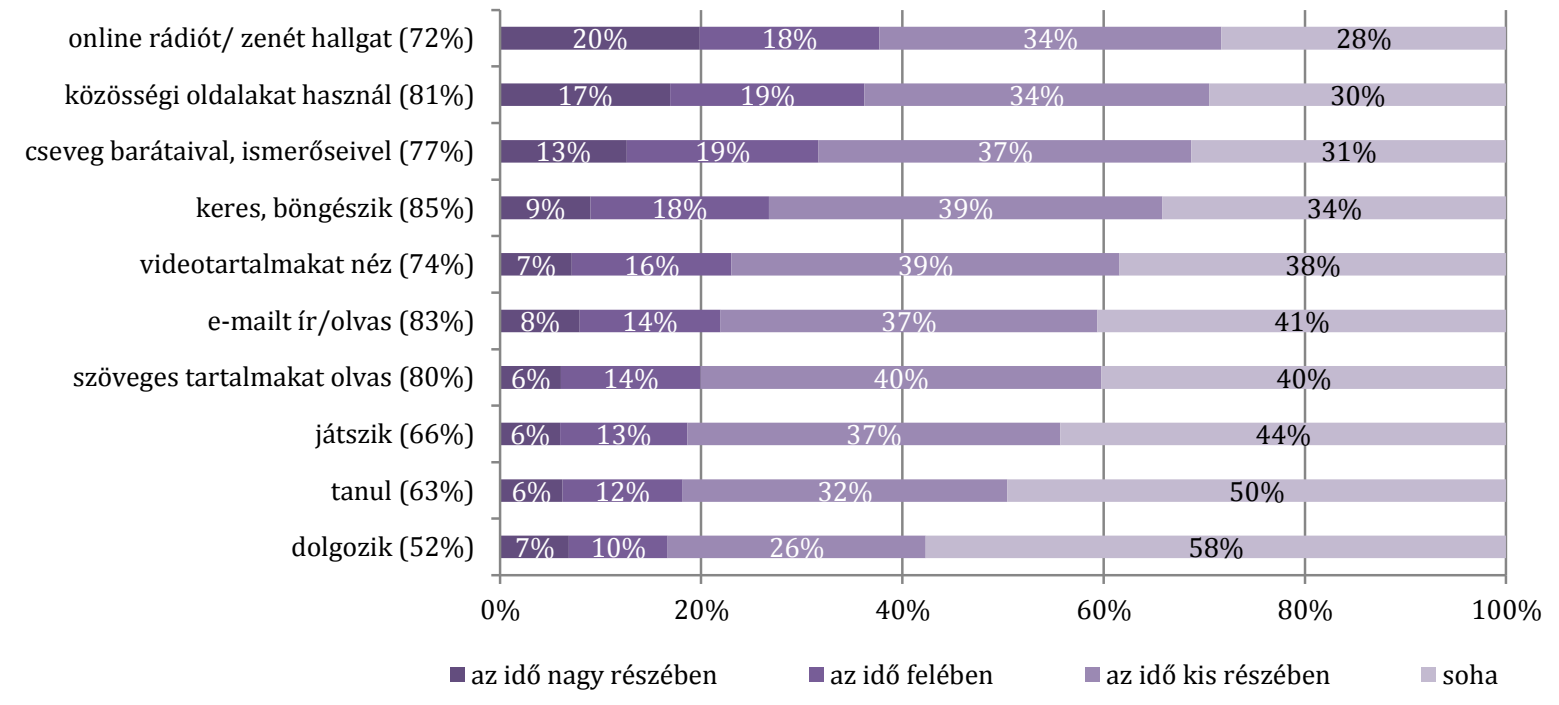

* zárójelben az adott tevékenységet folytatók aránya

\section{A multitasking befolyásolói}

A következőkben megkísérlem összefoglalni azokat a kvantitatív kutatásokban tapasztalt ismérveket, amelyek a párhuzamos fogyasztással összefüggést mutatnak.

Digitális megosztottság és digitális kompetenciák

A dolgozat elméleti fejezetében bemutatott gondolati struktúrának megfelelően a médiafogyasztás szerkezetének megváltozását vizsgálva is láthattuk, hogy a digitális megosztottság átalakítja az ismert médiafogyasztási típusokat. A digitális megosztottság (hozzáférés, használat, tudás) más korábban is meglévő különbségekhez hasonlóan alakul, illetve az információs társadalom rendszerszintú változásainak leképeződése ezért érdemes erről bővebben szólni.

A gazdasági világválságot megelőző két-három évben munkáló pozitív folyamatok következtében Magyarországon a digitális megosztottság, vagy digitális szakadék érezhetően (és számottevően) csökkent. Az infokommunikációs fejlődés társadalmi vetületeivel foglalkozó kutatásokra, így a Magyar Infokommunikációs Jelentésre is optimista hangulat volt jellemző, hiszen az adatok szerint életkor, településtípus és 
régiók szerint, a „digitális olló” záródni látszott, az információs társadalmi fejlettség szempontjából (is) hátrányos helyzetű csoportok lassan, de kitartóan dolgozták le hátrányukat az átlaghoz képest. Leginkább a származás, a szubjektív anyagi helyzet illetve a településtípus tekintetében történt jelentős előrelépés, utóbbi tekintetében a kutatóműhelyek tökéletesen egyetértenek.

A megosztottságot potenciálisan hordozó jellemzőket egy összefoglaló indexben, a Digital Divide Indexhez ${ }^{86}$ (DIDIX) hasonló összevont mérőszámban foglaltuk össze ${ }^{87}$. Olyan mérőszámot hoztunk létre, amely a DIDIX logikáján alapul'88, tartalmazza a számítógép és az internet hozzáférésére és használatára vonatkozó indikátorokat egyaránt. A vizsgált hátrányos helyzetű csoportok: nők, legalább 50 évesek; maximum általános iskolát végzettek, roma származásúak, szubjektív vagyoni helyzet alapján a depriváltak csoportjába tartozók ${ }^{89}$, végül a községekben lakók. Az összesített INDEX értéke a 2001-es 53-ról 2009-re 59-re emelkedett, azonban ez a 2007-es 65-ös szinthez képest egyértelmű visszaesést jelez. A gazdasági recesszió következtében inkább stagnáló, az egyenlőtlenségeket konzerváló hatás érvényesül, amit az összefoglaló index mellett a „laposodó” dimenziós indexek is mutatnak. A kor és az iskolai végzettség, azaz

\footnotetext{
${ }^{86}$ Számítógép- és internethozzáférés, valamint számítógép- és internethasználat általában és otthon. A DIDIX részletes leírása megtalálható: SIBIS New eEurope Indicator Handbook; 2003 és Hannes Selhofer Tobias Hüsing: The Digital Divide Index - A Measure of social inequalities in adoption of ICT; 2001

${ }^{87} \mathrm{Az}$ általában alkalmazott dimenziók a következők: kor, nem, iskolai végzettség, vagyoni helyzet, származás. Az index értéke egy adott hátrányos helyzetű csoport (pl.: nők, idősek, stb.) és a teljes populáció információs eszközökhöz való hozzáférés és használat arányát (pl.: az 50 év felettiek otthoni internethasználatának a fóátlaghoz arányított átlagát) mutatja meg. Az index értéke 0 és 100 között mozog, minél alacsonyabb az index értéke, annál nagyobb a hátrányos helyzetű csoport lemaradása az átlaghoz képest. Az egyes hátrányos helyzetű csoportokra külön-külön kiszámíthatóak az index értékei az indexek súlyozott összevonásával jön létre a DIDIX. A súlyozás azt jelenti, hogy a hozzáférési és használati indexek más-más súllyal szerepelnek az összegző DIDIX értékében.

${ }^{88} \mathrm{Az}$ indexek kiszámítása során a DIDIX módszertanát használtuk fel: A számítógép- és az internet hozzáférést az otthonokban és a számítógép- és internethasználatot (bárhol) vizsgáltuk. Az adott hátrányos helyzetű csoport (nők, legalább 50 évesek; maximum általános iskolát végzettek, roma származásúak, szubjektív vagyoni helyzet alapján a depriváltak csoportjába tartozók, községekben lakók) hozzáférési és használati arányát arányítottuk a teljes mintában tapasztalt hozzáférési és használati

arányokhoz $\frac{x_{i}}{x_{T}}$ A kapott arányokat súlyoztuk, a használatot 0,3-as, a hozzáférést 0,2-es súllyal majd összegeztük az egyes indexekben. ${ }^{D j=\sum_{i=1}^{n} w_{i} \frac{x_{i}}{x_{T}}}$ Az évenként összesített Indexet a részindexek számtani átlagával számoltuk ki. $I N D E X=\sum_{j=1}^{n} \frac{D j}{N}$

${ }^{89}$ Amely kiküszöbölni hivatott a személyes jövedelemből következtetetett vagyoni helyzetből adódó torzulásokat. (a WIP csak 18 év felettiek személyes jövedelmét kérdezi, ugyanakkor a fiatalok jelentékeny része nem rendelkezik személyes jövedelemmel, mert tanul, ezáltal a legalacsonyabb jövedelmi kvartilisbe kerül, ugyanakkor vagyoni helyzete ettől független.
} 
a digitális megosztottság klasszikus jellemzői továbbra is a legerősebb hatást mutatják, míg a nem egyre kevésbé számít.

A nem szerepe valójában még ennél is jelentéktelenebb. A fejlett országokban jórészt a közoktatásnak köszönhetően nincs a nem szerint érdemi különbség a technológiai eszközök használatában. A látszólagos különbséget az életkor magyarázza. Ahogy korábban egy blogbejegyzésben ${ }^{90}$ részletesen kifejtettem 2007-ben a férfiak 48, a nők 42 százaléka volt internethasználó, ami szignifikáns különbségnek bizonyult, ugyanakkor ha az internethasználat és a nem kapcsolatának értelmezésébe bevonunk még egy fontos tényezőt, az életkort, láthatóvá válik, hogy csupán a hatvan éven felüliek korcsoportjára igaz az feltétel nélkül, hogy a férfiak inkább használnak internetet, mint a nők, a fiatalabb korcsoportokban ugyanis nincs szignifikáns eltérés.

25. ábra: DIDIX (Forrás: WIP, 2001-2009)

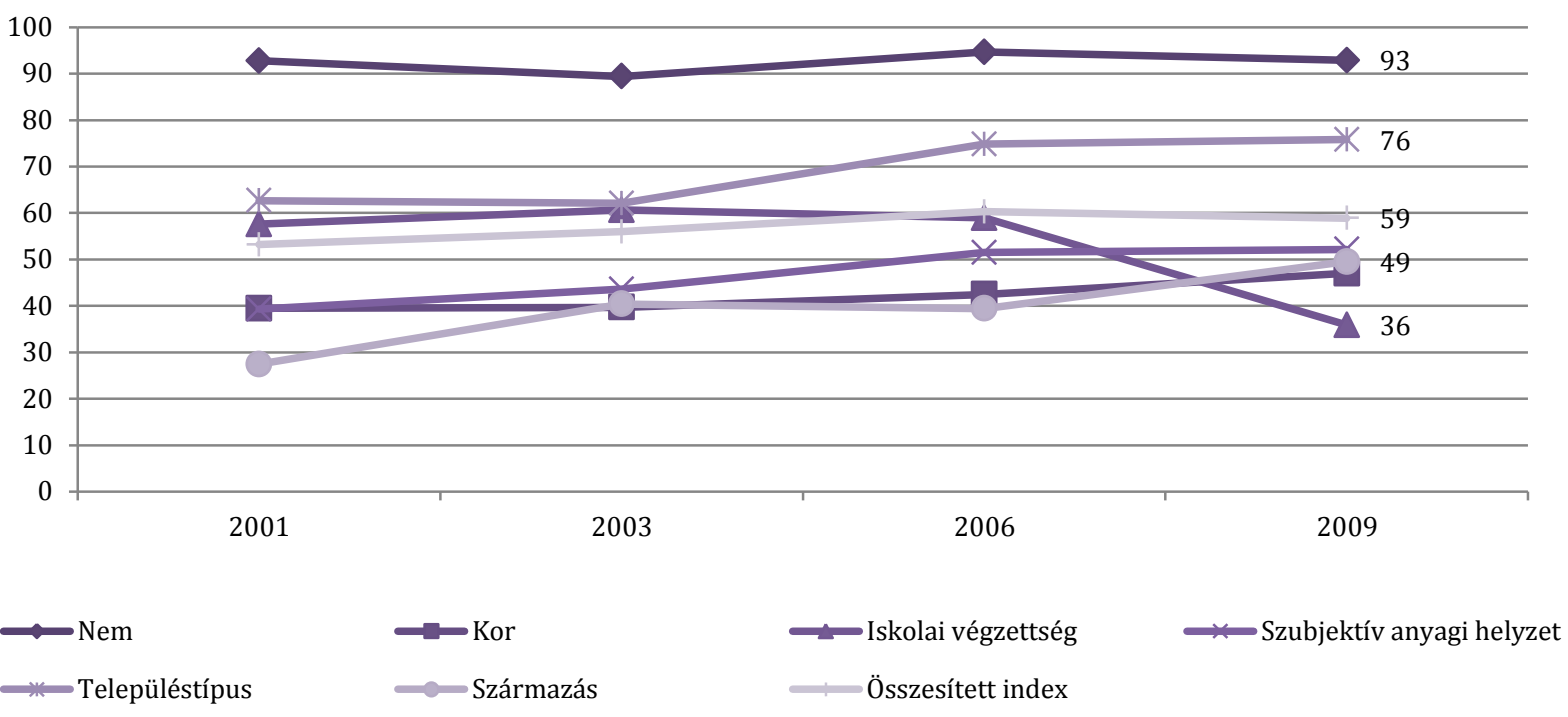

Mint a dolgozat elméleti fejezetében szó volt róla a használók - nem használók dichotómiára építő digitális megosztottság továbbgondolása abba az irányba mutat, hogy a használaton puszta tényén kívül figyelembe veszik a használat jellemzőit, az információs igényeket, azt, hogy a technológia miként segíti az egyéneket a mindennapi társadalmi életben.

A WIP kutatásokban rendszeresen mérjük a felhasználói tudást is. Természetesen csupán önreflexióról lehet szó, azaz a saját tudásukat szubjektív módon ítélhetik meg a

\footnotetext{
${ }^{90}$ http://infocore.blog.hu/2009/01/05/lazarsfeld es az internetezo nagymamak
} 
felhasználók. A 2007-es és 2009-es adatok vizsgálata után megállapíthatjuk, hogy némileg tovább nőtt a magabiztos felhasználók tábora. Összességében durván háromból ketten magabiztos felhasználóknak tekinthetők.

26. ábra: Internet-felhasználói tudás (Forrás: WIP, 2007-2009)

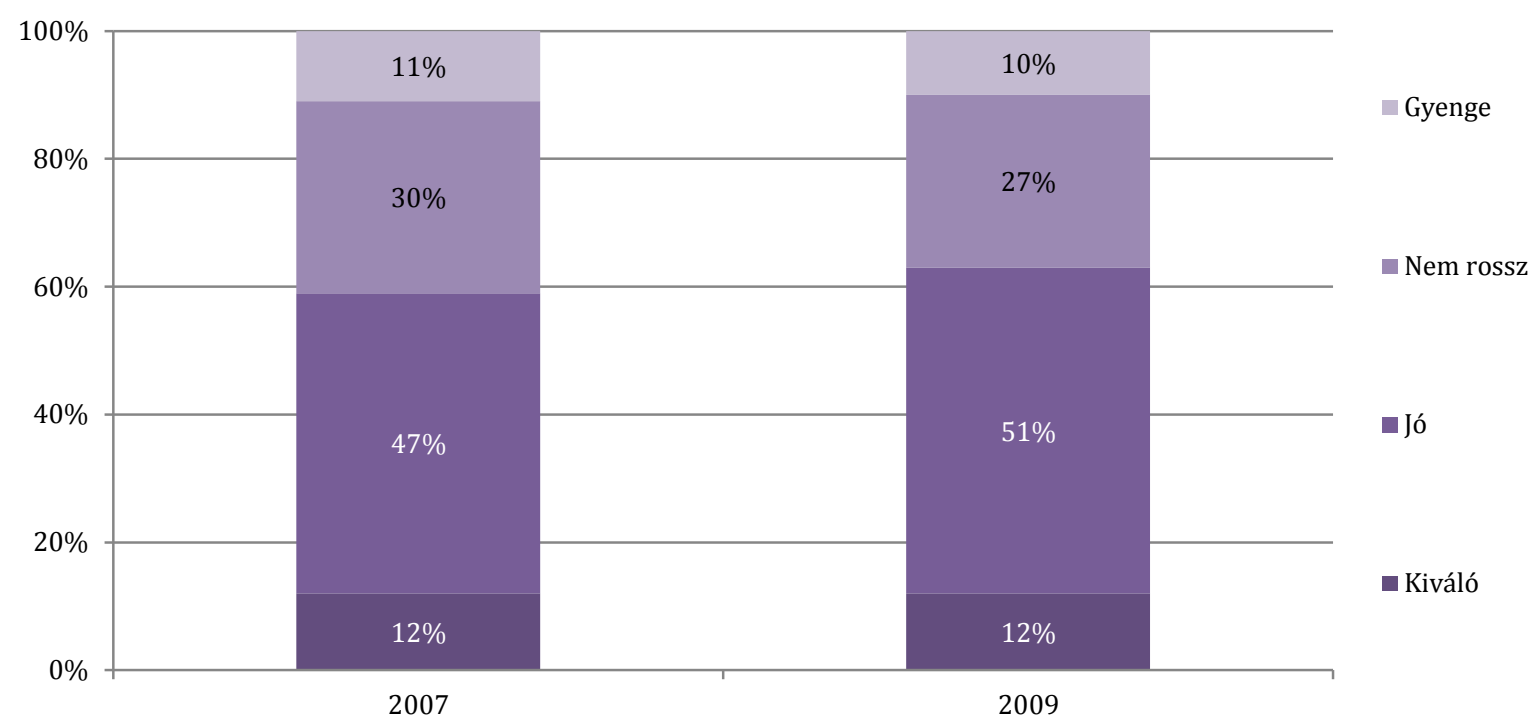

A legfrissebb WIP adatokból az is kiderül, hogy a magabiztos felhasználók a fiatalabb korcsoportból, leginkább a 30 alattiak közül kerül ki, ennek egyik oka lehet, hogy ők azok, akik legnagyobb arányban vesznek részt elsősorban szervezett iskolai képzéseken, illetve abból következhet, hogy a legfiatalabbak beleszületnek az információs társadalomba, az eszközök használatát a szocializációjuk során sajátítják el. A Nemzeti Hírközlési Hatóság 2009-es felmérése a felhasználói jártasságot nemzetközi példák alapján egy „objektív” és egy szubjektív 0-100 közötti indexen határozta meg, eszerint a magyar felhasználók átlagosan 56 pontot érnek el a szubjektív, míg 65-öt az objektív indexen, azaz nagyjából közepes az átlagos felhasználói tudás.

A World Internet Project 2007-es adatbázisa arra is lehetőséget ad, hogy megvizsgálhassuk a felhasználói tudás és a multitasking kapcsolatát, ezzel reflektálva azokra a felvetésekre, amelyek a párhuzamosságot a rutinhoz kötik. A tapasztalatok azt mutatják, hogy azok, akik gyakrabban végeznek más tevékenységeket is miközben interneteznek saját maguk falhasználói képességét jobbnak ítélték mint azok, akik ritkábban, vagy egyáltalán nem gyakorolják a multitaskingot. 
soha nem szokott előfordulni
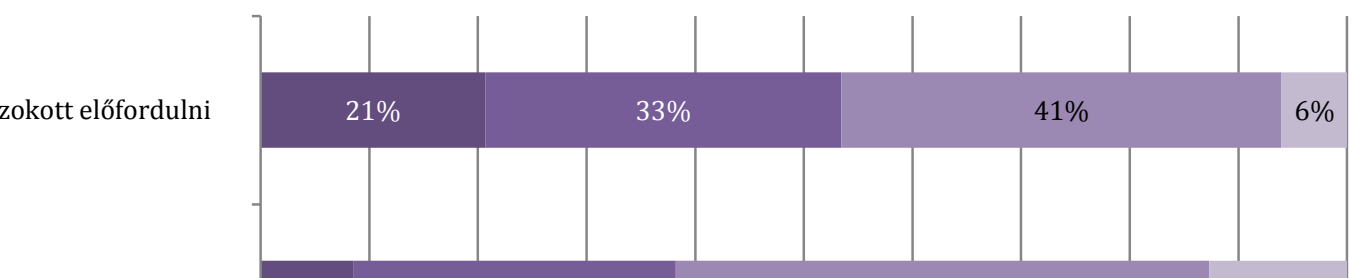

néha előfordul

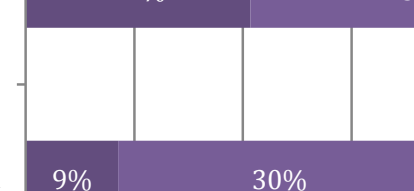

\section{(3)}
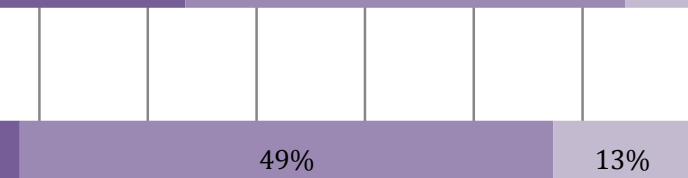

列

gyakran előfordul

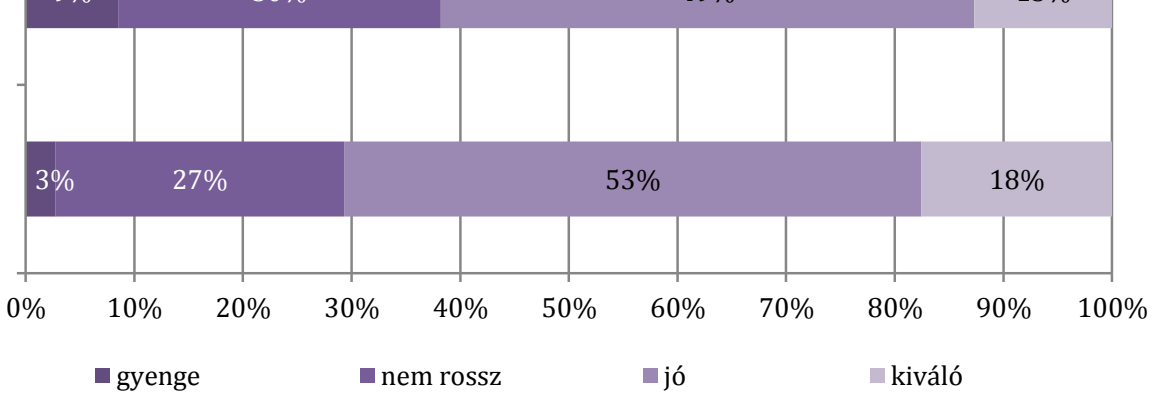

A felhasználói tudással kapcsolatban figyelemreméltó eredményeket találunk a Tükörterem keretében 2010-ben végzett iskolai kutatásunkban¹. A kutatásunkból kiderül, hogy a diákok szerint az életben való boldogulás során az egyik legfontosabb szerep az informatikáé, fontosságának megítélése évfolyamokon átívelő, azaz szinte mindenki egyetért ezzel. Ugyanakkor a diákok legkevésbé az informatika órákra készülnek - a tárgyat tanulók 57 százaléka sohasem készül órára. E a látszólagos ellentmondás hátterében minden bizonnyal az áll, hogy az oktatási rendszerben tanított informatika szintje nem jelent kihívást a diákok többségének.

A generációk közötti tanulást vizsgálva is visszaigazolhatók a korosztályok közötti tudásbeli különbségek, hogy a fordított irányú segítségnyújtás, azaz amikor a gyermek segít a szülőnek, gyakoribb, mint az egyenes irányú. Összességében a szülők kiegyenlítettebbnek látják ezt a viszonyt, de még így is dominánsabb a segítő, mint a segített gyermek. A diák válaszokat nézve ez az elválasztás sokkal markánsabb. A diákok mindössze egyötöde (19\%) mondta azt, hogy nem nyújt segítséget a szüleinek, viszont több mint fele (54\%) állította, hogy szülei sohasem segítenek neki.

\footnotetext{
${ }^{91}$ A kutatás internethasználatra vonatkozó eredményeit korábban már publikáltam: Székely L. (2010): Internetcsizma az iskolapadon - Esettanulmány egy régi vita margójára (in: Új Ifjúsági Szemle VIII. évfolyam 4. szám)
} 


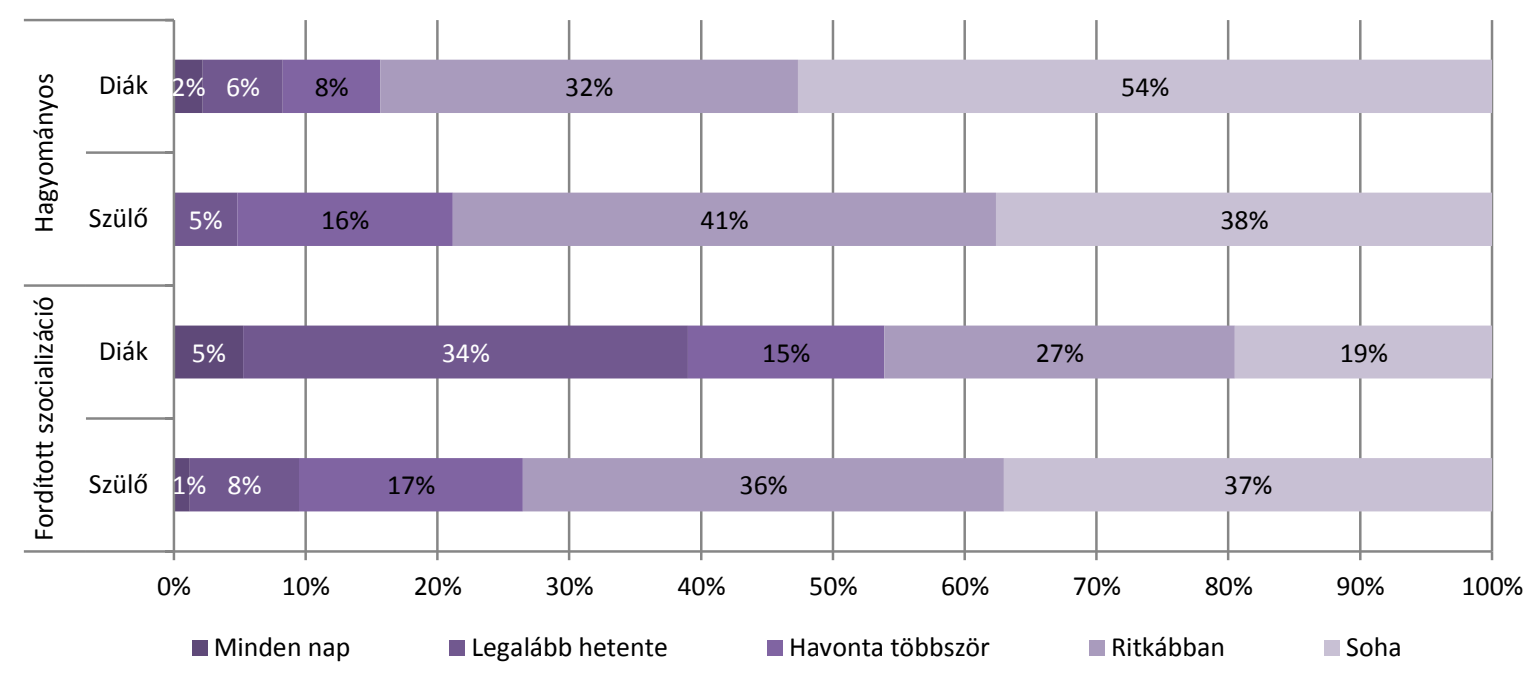

Klaszteranalízis ${ }^{92}$ segítségével négy karakteres csoportot hozható létre, ezek:

1. Önálló-konszenzusos csoportba tartozók, az összes család háromtizede (30\%), akik nem igényelnek, de nem is nyújtanak segítséget az internetezéshez.

2. Integrált-konszenzusos csoport az önálló csoportnak az ellentéte, jellemzője az átlagon felüli segítségadás és segítségnyújtás. A családok tizede (12\%) tartozik ebbe a csoportba.

3. Segítő szülő csoportba tartozók a szülői segítséget emelik ki, ide tartozik a családok ötöde (20\%). Itt is konszenzus jellemzi a gyermekek és szüleik megítélését.

4. Segítő gyermekek csoportja az egyedüli konfliktusos, ámbár a legnagyobb csoportosulás, a családok közel négytizede (38\%) tartozik ide. Jellemzőjük a gyermek segítségének dominanciája, amelyet a szülő csak részben igazol vissza.

${ }^{92}$ A klaszteranalízis (K-Means Cluster Analysis) során az otthoni közös internethasználatra és segítségnyújtásra vonatkozó kérdéseket használtam fel. Ez a diákok kérdőívében a következő volt: Mennyire jellemző, hogy otthon...

a, segítesz a szüleidnek, a számítógép, internet használatában

b, a szüleid segítenek neked a számítógép, internet használatában

Ugyanez a szülői kérdőívben a következőképp hangzott: Mennyire jellemző, hogy otthon...

a, segít önnek gyermeke a számítógép, internet használatában

b, ön segít gyermekének a számítógép, internet használatában

A válaszlehetőségek mindkét esetben a következők voltak: minden nap; hetente párszor; havonta többször; ritkábban; soha. A klaszteranalízis során többféle klaszterstruktúrát kipróbáltam, összességében ez a négyes felosztás volt a legjobban interpretálható, illetve a csoportok mérete ebben az esetben volt a legmegfelelőbb. 
Az egyes csoportokat mélyebben megvizsgálva elmondható, hogy az önálló és a segítő szülői csoportban felülreprezentáltak a lányok, míg a konfliktusos és az integrált csoportban a fiúk. Az évfolyam növekedésével jellemzően növekszik a konfliktusos csoportba tartozók aránya, és csökken a segítő szülők csoportjának létszáma. Mindezek alapján talán nem meglepő, hogy a konfliktusos csoportban a legmagasabb (18 óra hetente) és a segítő szülői csoportban a legalacsonyabb (12 óra hetente) az internetezés mennyisége.

A felhasználói tudás és az életkor összefüggései arra figyelmeztetnek, hogy a multitasking és a felhasználói tudás kapcsolata lehet pusztán olyan látszatkapcsolat, amelyet valójában az életkor magyaráz. A kérdés vizsgálatára alkalmas lehet egy - a kis elemszámok miatt leegyszerűsített - háromdimenziós kereszttábla. Mint az alábbi táblázatban is láthatjuk a legfiatalabb korcsoportokban a jó vagy kiváló felhasználói tudással a párhuzamosságot gyakorlók vannak többségben, míg a legidősebb két korcsoportban a gyengébb felhasználói tudással rendelkező a multitaskingot nem gyakorlók. A legfiatalabbak, a harmincasok és az 50 évesek, vagy idősebbek korcsoportjaiban nincs szignifikáns különbség a felhasználói tudás között, míg a huszonévesek és a negyvenesek között a Pearson féle Khi négyzet statisztika szerint is azok gyakorolják a multitaskingot inkább, akiknek jobb a felhasználói tudásuk.

20. táblázat: Felhasználói tudás és multitasking korcsoportok szerint (Totál százalékok, N=1349; Forrás: WIP, 2007)

\begin{tabular}{lccc}
\hline & multitasking & gyenge vagy nem rossz & jó vagy kiváló \\
\hline \multirow{2}{*}{$\mathbf{1 4 - 1 7}$ évesek } & nem szokott & $7 \%$ & $14 \%$ \\
& szokott & $22 \%$ & $56 \%$ \\
\multirow{2}{*}{$\mathbf{1 8 - 2 9}$ évesek } & nem szokott & $10 \%$ & $14 \%$ \\
& szokott & $21 \%$ & $56 \%$ \\
\multirow{2}{*}{$\mathbf{3 0 - 3 9}$ évesek } & nem szokott & $21 \%$ & $21 \%$ \\
& szokott & $24 \%$ & $35 \%$ \\
\multirow{2}{*}{$\mathbf{4 0 - 4 9}$ évesek } & nem szokott & $30 \%$ & $17 \%$ \\
& szokott & $20 \%$ & $33 \%$ \\
\hline \multirow{2}{*}{$\mathbf{5 0 - 5 9}$ évesek } & nem szokott & $34 \%$ & $19 \%$ \\
& szokott & $24 \%$ & $23 \%$ \\
\hline
\end{tabular}


Mindezek alapján egy olyan - egyelőre csak - hipotézist alkothatunk, miszerint a multitasking gyakorlása összefügg a felhasználói tudással, azonban a legfiatalabb és legidősebb korcsoportokban a felhasználói tudás nem domináns.

\section{Társadalmi-gazdasági szempontok}

A korábban is használt szociodemográfiai jellemzőket tekintve nem minden esetben találhatunk lényegi magyarázatokat. Fentebb utaltam rá, hogy a nemzetközi tapasztalatok nemi különbségekre is felhívják a figyelmet, erre azonban a WIP adataiból statisztikai értelemben megbízható módon nem következtethetünk.

A legerősebbnek bizonyuló összefüggést nem meglepően a kor esetében találjuk. Az alábbi ábrán jól látszik, hogy szinte tökéletesen lineáris kapcsolat van az életkor és a párhuzamos médiafogyasztás gyakorisága között, míg a 29 évesek vagy ennél fiatalabbak háromnegyede (74\%) szokott internetezés közben más (média) tevékenységeket is folytatni, addig a 60 évesek, vagy annál idősebbek hattizede (59\%) távol marad ettől. A közbeeső korcsoportok e két véglet között helyezkednek el.

Figyelemreméltó, hogy a legnagyobb különbség a szociológiai értelemben vett fiatal (30 év alattiak) és a harmincas éveikben járók között húzódik, továbbá a gyakori párhuzamos médiafogyasztást folytató csoport hasonló nagyságrendű (10-16\%) minden korcsoportban kivéve a fiatalokat, ahol minden harmadik kérdezett ide tartozik. 
29. ábra: Internetezés közben más médiumok fogyasztásának gyakorisága korcsoportok szerint (N=1096; Forrás: WIP, 2009)

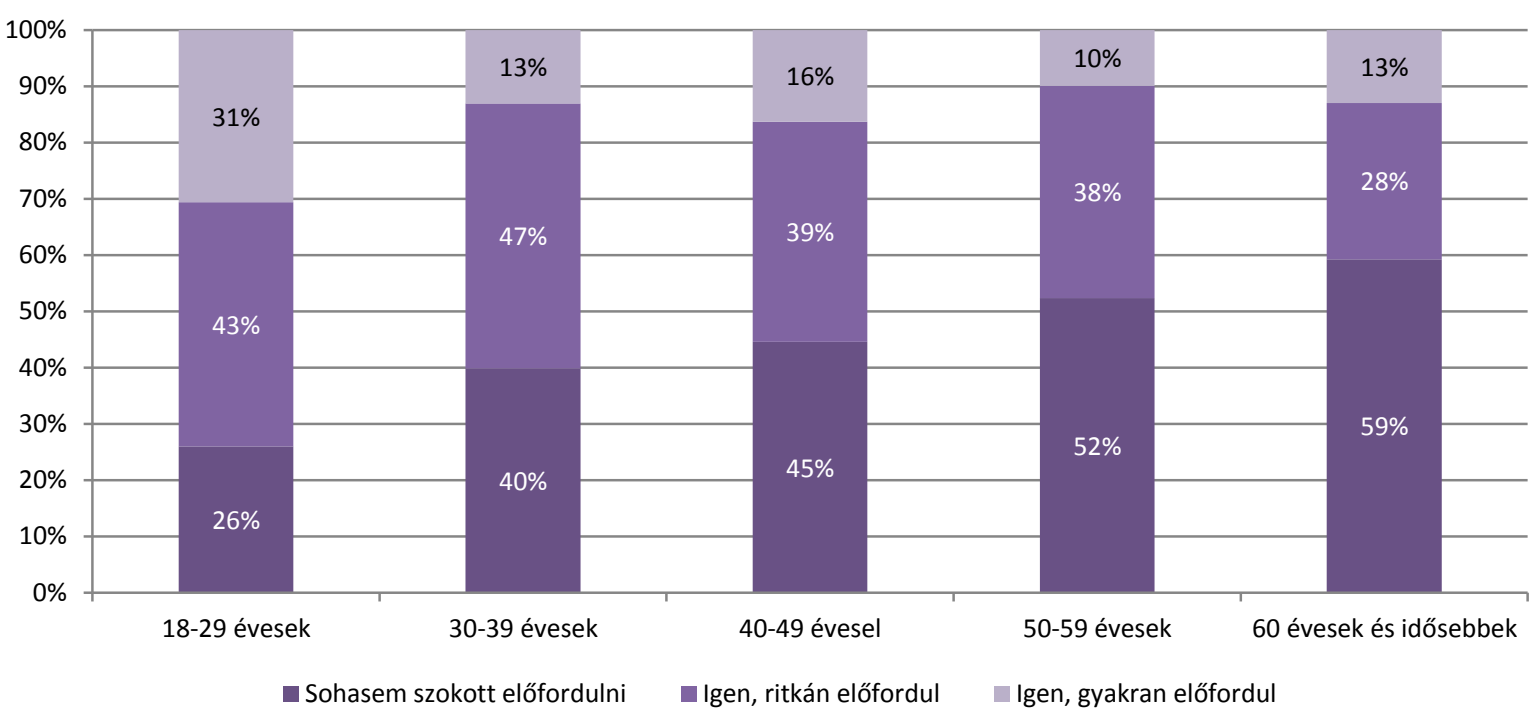

Szignifikáns magyarázatot találhatunk továbbá, ha a szubjektív anyagi helyzet szerint vizsgálódunk. Ahogy az alábbi ábrán is látható a legjobb anyagi körülmények között élők csoportjában van a legtöbb olyan ember, aki gyakori egyidejű többcsatornás médiafogyasztó. Az életkorhoz hasonlóan ebben az esetben is megfigyelhető, hogy egyértelmű iránya van, az anyagi körülmények javulásával nő a multitasking esélye.

30. ábra: Internetezés közben más médiumok fogyasztásának gyakorisága szubjektív anyagi helyzet szerint (N=1056; Forrás: WIP, 2009)

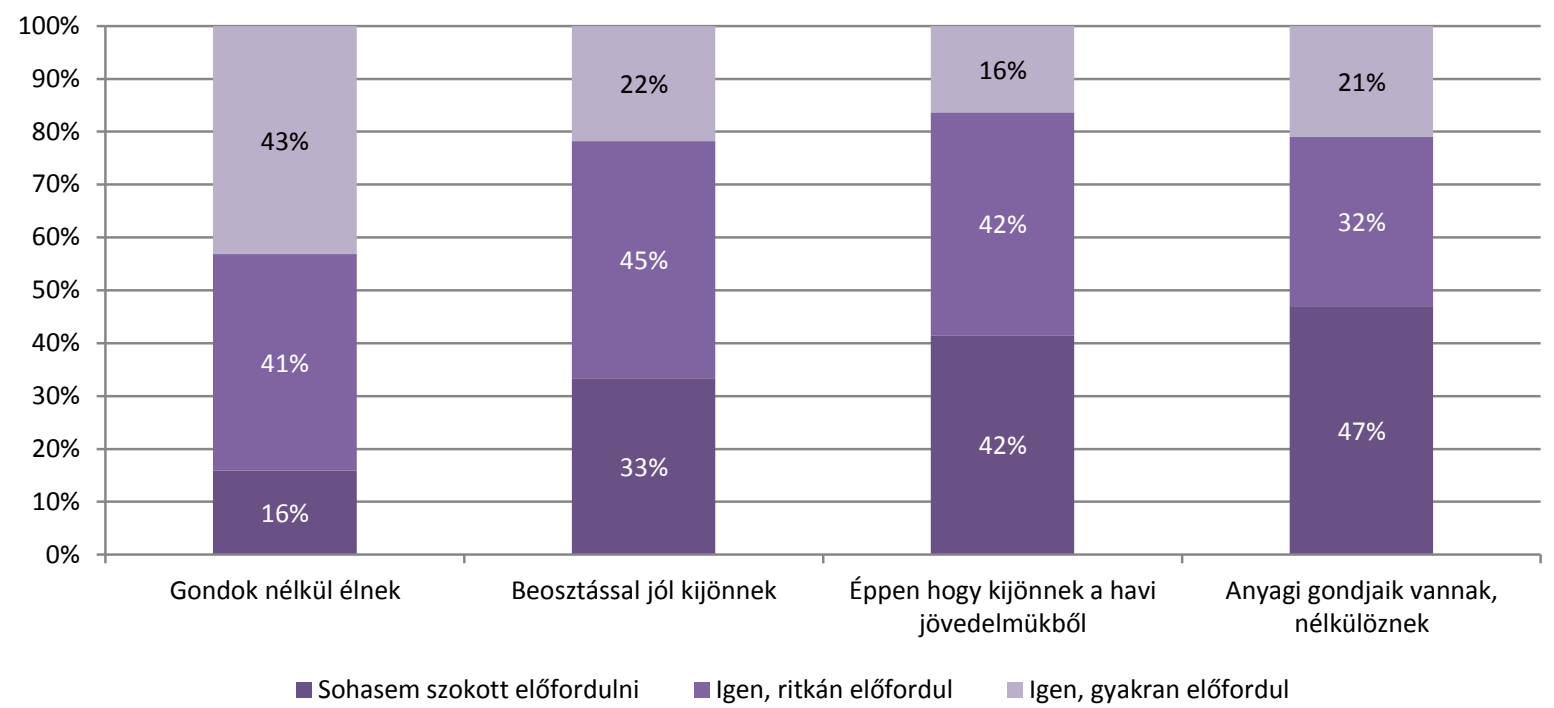


Az Információs Társadalom- és Trendkutató Központ (ITTK) valamint az NRC Piackutató együttműködésében készült online felmérésből is hasonló eredményekre juthatunk. A vizsgált szociodemográfiai jellemzők közül legerősebbnek a nem és a kor bizonyul, azonban csak utóbbi eredményezett szignifikáns magyarázatot. Mindkét jellemző a korábbi tapasztalatok alapján megfogalmazható hipotéziseket igazolja, azaz az onlineoffline média multitasking jellemzőbb a nőkre, valamint a fiatalokra. 


\subsection{GENERÁCIÓS ÉS ÉLETKORI HATÁSOK}

A WIP adataiból kiinduló korábbi kutatásokban (Pintér - Székely, 2006; Székely 2006; 2007) már foglalkoztunk a médiafogyasztás és a kor összefüggéseinek kérdésével. Ezen kutatások során a korcsoportok jellemzői is összehasonlításra kerültek, és az derült ki, hogy a fiatalok (tizenévesek) médiafogyasztása gyökeresen különbözik az idősebbekétől, olyannyira, hogy a mai fiatalok új szokásaikkal átalakíthatják a ma ismert médiafogyasztási világot.

A változást a médiapiac is érzi, hiszen - nemzetközi trendekbe illeszkedően Magyarországon is egyre csökken a közéleti lapok példányszáma, úgy túnik, hogy a fiatalabbak egyre kevesebb időt töltenek hagyományos (offline) újságolvasással. Elfordulni látszanak a rádiótól és a televíziótól is, amivel együtt jár a rádió és a televízió szerepének megváltozása, a háttérrádiózás és televíziózás elterjedése. A médiafogyasztás mennyiségének és a kor kapcsolatának vizsgálata során megfigyelhető, hogy a médiafogyasztással töltött időben a generációs törést több esetben is a húszas éveik végén járóknál találjuk, ami azt jelenti, hogy ez a korosztály testesíti meg a fiatalság határát médiafogyasztás szempontjából. Annak, hogy pont itt következik be a változás, több oka is lehet, egyrészt a munkaerő-piaci integráció, másrészt a családalapítással megváltozó fogyasztói szokások és igények. A gazdasági és társadalmi helyzet megváltozásához hozzájárul az információs társadalomhoz való viszonyulás.

A fiatalokra már joggal mondhatjuk, hogy ők a digitális kor értékvilágát és szocializációját felmutató $\mathrm{Y}$ és $\mathrm{Z}$ generáció, az idősebbek számára viszont egy másik korszak, a rendszerváltás előtti és körüli pre-digitális világ a meghatározó emlék. Előreláthatólag az internet további terjedésével a gyermekkorból fiatalkorba lépő generációk még inkább involválódnak a digitális világba, és médiafogyasztásuk várhatóan még kevésbé illeszkedik majd a klasszikus képhez. Mivel a legfrissebb 2009es adatok csupán a 18 év felettiekre vonatkoznak ismét érdemes a korábbi adatbázisokból részletesebben is dolgoznunk.

Korábbi munkánkban az életkor és a médiafogyasztás mennyiségének kapcsolatát vizsgáltuk (Pintér - Székely, 2006) és jó néhány, a fiatalok médiafogyasztására vonatkozó sztereotípiáról bizonyítottuk be, hogy minden alapot nélkülöz. A vizsgált sztereotípiák, vagyis hogy a fiatalok sokat néznek tévét, keveset olvasnak, illetve túl 
sokat telefonálnak az adatok alapján hamisnak bizonyulnak. A WIP 2004-es adatai alapján elmondható, hogy a 14-17 év közötti korcsoport - amelyet a tanulmányunkban „mai fiatalok” korosztályaként nevesítettünk - olvas a legtöbbet könyvet ma Magyarországon, hozzájuk hasonló (szignifikánsan nem kevesebb) időt töltenek olvasással hetente a 26-27 év alatti, illetve az 58-59 és afeletti korosztályok. ${ }^{93}$ Bár könyveket a fiatalok olvasnak leginkább - míg a 14-29 évesek több mint négytizede legalább hetente olvas könyvet, ugyanez az idősebbek mintegy harmadát jellemzi - az újságok esetében azonban úgy tűnik, hogy egyszerűen „kihalnak” az olvasók, ugyanis a fiatalabb korosztályok egyre kevesebb időt töltenek újságolvasással.

A Budapesti Corvinus Egyetemen készült, kifejezetten a fiatalok párhuzamos médiahasználatára koncentráló kutatásból megállapítható, hogy a 14-23 évesek többsége gyakran olvas, bár az olvasott könyvek stílusa egészen különböző lehet. Van, aki sok sci-fit, meg filozófiát, van aki szinte mindenevő: „regények, pszichológia-filozófia dolgok, kommunikációval, metakommunikációval kapcsolatos művek”, mások csak kötelező irodalmat. Mivel az olvasás sok időbe kerül, azaz a nem tankönyvjellegű olvasmányokra „kell külön szabadidő” ezért megpróbálják ötvözni más tevékenységekkel, van például, aki a tömegközlekedési járműveken olvas, az egyik tizenéves lány azt említi, hogy főleg nyaranta olvas, „mert Szentendrén van nyaralónk, és ott nincs net”. Az egyik huszonéves fiú az olvasmányait is nagyon gyakorlatiasan választja ki, elmondása szerint nem szereti az olyan könyveket, amelyek történetet mesélnek el, hanem az olyan könyvek a jók, „amiből meg lehet valamit tanulni, hogy valamit hogyan kell csinálni".

A fókuszcsoportos tapasztalataink azt mutatják, hogy akik a könyveket kevésbé kedvelik, azok inkább újságokat, magazinokat olvasnak, például az egyik tizenéves, budapesti fiú gyakran olvas számítógépes magazinokat és autós magazinokat, ugyanakkor a könyveket (egyelőre) elkerüli, ahogy magáról állítja: „Önszántamból könyvet egyet olvastam el egész életemben."

A beszélgetéseken résztvevő fiatalok gyakran olvassák az ingyenes Metro (ma már Metropol) újságot és más ingyenes újságokat, egyébként sem jellemző, hogy bármilyen

\footnotetext{
${ }^{93}$ Az említett korosztályok képviselik a generációs töréspontokat, ez nem jelenti azt, hogy nem fordulhat elő, hogy egyes korcsoportok „kilógnak a sorból”. A töréspontok azt mutatják meg, hogy melyik korcsoporttól kezdve változik egyértelműen a médiafogyasztás mintázata.
} 
újságot megvennének, inkább azokat olvassák, amelyekre családtagjaik (apa, anya, nagyapa, nővér) előfizetnek.

„Nem adok ki pénzt napilapokra. Autósmagazint olvastam régen, de leszoktam róla, mert a neten annyiféle van. Maximum egy nagyobb utazás elött az állomáson vett lapokat." (22 éves, heavy multitasker fiú)

Akik mégis szoktak vásárolni lapokat, azok kizárólag tematikus lapok, magazinjellegűek, napilapokat senki sem vásárol. Többen említik a National Geographic-ot, valamint az igényesebb kulturális, életmód, divat, zene és stílus magazinokat. Természetesen ízlésben élesen elválnak a lányok a fiúktól, előbbiek a „csajos és életmód magazinokat” olvassák inkább, utóbbiak autós-motoros, számítástechnikai lapokat. A beszélgetés némely résztvevőjének, olyan meghatározó hobbija van, amelyhez olvas tematikus lapokat is, említették például a HVG-t, az Új Művészetet, a Históriát.

A WIP adatait elemezve kijelenthetjük, hogy a zenehallgatás az a terület, ahol a sztereotípia igaz, a fiatalok hallgatnak a legtöbbet és leggyakrabban zenét és itt találjuk a legnagyobb mennyiségbeli eltéréseket is a különböző korosztályok között. A fiatalok (14-29 évesek) több mint fele (56\%) naponta hallgat zenét, a középkorúak (30-59 évesek) mindössze valamivel több mint negyede tesz ugyanígy, míg az idősek (60 felettiek) csupán 5\%-a. A generációs töréspontot a 26-27 éves korcsoport esetében találjuk, ők a heti közel 9 óra zenehallgatással, már szignifikánsan kevesebbet hallgatnak, mint a referenciakategóriát képviselő 14-17 évesek. A mennyiségi különbségek hátterében feltehetőleg, korcsoportok szerint szerveződő, eltérő zenehallgatási és megosztási kultúrát találunk. A mai fiatalok egy mp3 megosztásletöltés és hordozható lejátszó uralta világban szocializálódnak, ahol a „jó zene” könnyen és gyorsan beszerezhető - részben illegálisan. A zeneiparnak tehát bár hosszútávon ugyanúgy az üzleti modell fenntarthatatlanságával kell szembenéznie, mint az újságoknak vagy a könyvkiadásnak, paradox módon éppen ellentétes okokból kifolyólag: nem a tevékenység elhalása fenyeget, hanem az egyre élénkülő igények csillapíthatatlan, de alternatív, piacon kívüli forrásból táplálkozó kielégítése, azaz az illegális zeneletöltés jelenti a kihívást.

A 14-23 évesek körében végzett fókuszcsoportos kutatásunk is megerősíti a kvantitatív tapasztalatokat. Megállapíthatjuk, hogy legyen tizenéves, vagy huszonéves az ember, a 
zene nagyon fontos az életben. „A zene alap” fogalmazzák meg többen is. Fontosságát jelzik a hozzá kapcsolódó megállapítások:

- „én egyébként állandóan zenét hallgatok”;

- én nagyon zenefüggő vagyok";

- „Ha valaki csúnyán beszélt velem, akkor lefekszem és bekapcsolom a zenét, hogy ne legyek szomorú, vagy legyek még szomorúbb";

- „csak úgy átfut rajtam, úgy átélem a dolgokat” aztán „a hangok képekké alakulnak" (sokat rajzol);

- „Ha nem vagyok otthon és nincs velem senki, akkor zene nélkül nem tudok létezni, buszon muszáj hallgatni, olyan nincs, hogy nem. Egy hónappal ezelőtt lemerült az mp3-mam és olyan szinten ideges voltam..."

A zenehallgatás esetében némileg elválik egymástól a szűrőkérdőív alapján előzetesen felosztott csoportok véleménye. A multitasking csoportokban a „zene a számítógépről megy folyamatosan”, tanulás közben is szól. Míg azok, akik a szűrőkérdőív alapján nem kerültek a multitasking csoportba sokkal kevésbé hallgatnak zenét egyéb tevékenységek, leginkább tanulás közben.

A rádió hallgatásának kor szerinti megoszlásáról alkotott közkeletű kép sokkal inkább a tartalmak tekintetében (közszolgálati-kereskedelmi) létezik, mint a mennyiség tekintetében, természetesen ez nem jelenti azt, hogy különbség nem lenne. A fiatalok rádióhallgatási gyakorisága az újságolvasáshoz hasonló mintázatot mutat, azaz a 14-29 év közötti fiatalok közül mintegy 10 százalékkal kevesebben hallgatnak rádiót naponta, mint az idősebb korosztályok. A heti rádióhallgatási mennyiséget tekintve már a 22-23 éves korcsoportban töréspontot találunk, innentől kezdve a kérdezettek szignifikánsan többet rádióznak. A rádió esetében elmondható, hogy bár továbbélését tulajdonképpen az internet nem veszélyezteti, ugyanakkor kérdés, hogy a meglévő adók milyen gyorsan ismerik fel az internetben, az internetes rádiózásban rejlő lehetőségeket?

A fókuszcsoportos beszélgetések alapján is látszik, hogy a rádió keresi helyét a fiatalok életében, ma már nem azt jelenti, amit a korábbi generációk számára jelentett. Egyértelműen háttérbe szorult, csak pótszer, ahogy a beszélgetéseken résztvevő fiatalok több esetben is megfogalmazták másodlagos helyzetét. Vannak azonban olyanok, akik szoktak rádiót hallgatni, de inkább beszélgetős és hírműsorokat, mint zenét. 
„ha lemerül az mp3-mam, vagy nincs kedvem zenét hallgatni, akkor hallgatom". (17 éves, heavy multitasker lány)

„Ha jó mp3-om van, vagy van az autóban egy CD, amit még nem hallgattam agyon, akkor inkább azt hallgatom." (22 éves, heavy multitasker fiú)

„Nem hallgatok rádiót egyáltalán, csak zenéket a gépen, vagy ha valami (beszélgetős müsor témája) érdekel, akkor az szól a gép mellett.” (15 éves, heavy multitasker fiú)

Figyelemreméltó összefüggéseket tapasztalhatunk a telefonálás és a kor tekintetében, mennyiségi dimenzióban ugyanis - akárcsak a könyveknél - fordított mintázatot kapunk, mint a sztereotípia feltételezi, azaz nem tűnik igaznak, hogy a fiatalok sokkal többet beszélnének, mint az idősebbek. A telefonálás gyakoriságát szemügyre véve azonban azt találjuk, hogy a fiatalok (14-29 évesek) kétharmada naponta használja a telefont, a középkorúak fele, míg az idősek mindössze negyede viselkedik ugyanígy. A különbség valószínűleg az eltérő használati módokból adódik, azaz a fiatalokra a szabadidős beszélgetések jellemzőek, szemben a hivatalos, munkához kapcsolódó telefonokkal.

A fiatalok körében végzett fókuszcsoportos vizsgálatban nem tértünk ki kifejezetten a telefon szerepére, azonban a beszélgetéseken sokszor előtérbe került a telefon. A tapasztalatok azt mutatják, hogy a fenti megállapítások csak részben igazolhatók. Bár a telefon leginkább a szabadidős beszélgetésekhez kötődik és mások telefonszámának birtoklása már egyfajta intimitást jelent, mert akárkinek nem adják meg a számukat (arra ott az $\mathrm{MSN}^{94}$ ), ugyanakkor hivatalos ügyekben is használják, pl. a reklamációkat jobb telefonon intézni, hiszen „kiabálni a telefonban jobb”.

A WIP adatai a sztereotípiának, miszerint a fiatalok sokat tévéznek ellentmondani látszanak. A fiatalok (14-29 évesek) többsége (86-87\%) naponta néz televíziót az idősebb korcsoportok azonban még ennél is nagyobb, több mint kilenctizedes (93\%) arányban teszik ugyanezt. A televízió előtt eltöltött idő tekintetében a legidősebb korosztályok mutatnak kiemelkedő eredményt, a csúcsot a 68-69 évesek tartják heti

\footnotetext{
${ }^{94} \mathrm{Az}$ MSN azonnali üzenetküldő szolgáltatása az ezredforduló után, a 2000-es évek második felében lett egyre népszerübb. A fiatalok körében készült fókuszcsoportos kutatáskor az egyik, ha nem a legnépszerúbb online csevegő szolgáltatás volt, amelyet mára szinte teljesen kiszorított a Facebook.
} 
közel 24 óra televíziózással, a fiatalok televíziózása ezzel, szemben kifejezetten visszafogottnak tekinthető.

A fókuszcsoportos kutatásunkból is a televízió leértékelődése mutatkozik meg. A televízióval kapcsolatos kijelentéseiket általában negatív kontextusban fogalmazzák meg a beszélgetések résztvevői, ami arra enged következtetni, hogy számukra a televízió értéktelen, tévét nézni időpocsékolás, nincs szükségük rá. Tudatosan megpróbálják kirekeszteni a televíziót az életükből. Hiába van a szobában televízió, van ahol „egy éve nem volt bekapcsolva”. Akiknek nincs külön tévéjük ott „nem is hiányzik”.

Ahogy az egyik huszonéves fiú mondta a tévékészülék száműzve lett a szobákból, a nappaliból is, egy külön szobába. „Nincs az, hogy leülök kajálni és bekapcsolom a tévét. Jó húzás volt édesanyámtól, de ezt csak későn érte el, úgyhogy mindenki tévéfüggő.” Az egyik budapesti tizenéves lány elmesélte, hogy annak ellenére sem akar saját tévét a szobájába, hogy a szülei sokszor kérdezgetik. Aggódik az egészsége miatt, mert rossz a szeme és nem akarja, hogy tovább romoljon (azonban a számítógép képernyője esetében ez az aggodalom nincs jelen).

Habár a kvantitatív kutatások rendre azt fogalmazzák meg, hogy a televízió leginkább magányos tevékenység, a fókuszcsoportokon a legtöbb esetben ennek ellenkezőjét figyelhettük meg. Úgy tűnik, hogy az internetező multitasking generáció számára a televízió inkább társasági esemény (szemben a zenével, ahol az ízlések alig összeegyeztethetőek). Az egyik csoportban megfogalmazzák, hogy amíg nem volt az internet ennyire fontos, addig a családban mindenkinek volt egy külön tévéje, de mióta van, azóta csak egy van a nappaliban. „Egy család vagyunk, meg kell egyezzünk abban, hogy mit nézünk.” Egy másik tinédzser fiú elmondása szerint „akkor nézem a tévét, ha a család nézi, hogy együtt legyünk”. Vagy, ahogy egyik lány megfogalmazta „pihentetésképpen ráálltam egy-két sorozatra, de csak a családdal. Ha egyedül lennék nem biztos, hogy bekapcsolnám”. Egy másik lány a következőképpen fogalmazza meg ugyanezt: „Ha valaki nézi a családból, akkor belenézek, de nem érdekel, nem nagyon kapcsolom be. Föleg a szüleim nézik, néha leülök melléjük, ha olyan érdekesebb téma van, vagy csak úgy, ha van időm."

A fentiekből következtethetünk arra, hogy az otthonokban leggyakrabban nem a fiatalok kapcsolják be a televíziót, hanem a család többi tagja. Azok a műsorok, amelyeket saját maguk választanak ki, leginkább a híradók és a sorozatok. Ahogy egyikük 
megfogalmazza „a híradót, azt megnézem, de a valóságshow-k annyira már nem érdekelnek". Van arra is példa, hogy a tévé (illetve minden más eszköz, ami hangot és/vagy képet adhat) ugyan be van kapcsolva, de csak úgy megy a háttérben. „Hazaérek bekapcsolom a tévét, meg a gépet, de nem nézem, csak megy."

Többen az utóbbi időben nagyon tudatossá tették a tévézésüket, mivel „nagyon sok idejét elveszi az embernek, úgy mint az internet. Ha nem szabok határt magamnak órákat lehet ott eltölteni, mert az ember nem érzi, hogy fáradt." Egy tinédzser fiú a következőket mondja:

„Azért iktattam ki a tévét, mert ha engem egy valami érdekel, akkor én nem akarok mással foglalkozni, ha nézem a Híradót, nem akarom tudni, hogy Dundika mit csinált. Nem érdekel. Ezért én minden információt az internetről szedek le. Ez gyorsabb, hamarabb jutnak el hozzám az információk interneten keresztül, mint tévén és talán nem biztos, hogy torzítják a tévével ellentétben. A televízió nem pártatlan, az internet sokkal inkább az. Ami a Híradóban van, azt már régen tudom a netről." (15 éves, heavy multitasker fiú)

A tudatosság nem pusztán abban merül ki, hogy megkísérlik korlátozni a tévé előtt eltöltött időt, hanem megpróbálják a szórakozást ötvözni a tanulással, így előszeretettel néznek eredeti nyelven filmeket, ha megtehetik, vagy ismeretterjesztő csatornákat. Sokan inkább letöltik a filmeket, amelyek érdeklik őket és így nézik eredeti nyelven, ráadásul így a frissebb részekhez férhetnek hozzá, pl.: egy-egy sorozatból itthon még csak a harmadik évad megy, de a netről már le lehet szedni a negyediket. Mások csak a valóban őket érdeklő tartalmat nézik „van egy sorozat, amit nézek, amihez ragaszkodom. De a reklám alatt lehalkítom a tévét, addig igyekszem magam hasznosan elfoglalni.”

Sokak számára a televízióadás hordozója is a számítógép, többen említették, hogy van TV-tuner a számítógépükben, így ha akarnak, tudnak a számítógépen keresztül is tévézni. A beszélgetések résztvevőinek nagyjából harmada rendelkezik saját számítógéppel, a kétharmaduk azonban nem, ezekben a családokban kisebb-nagyobb konfliktusok forrása a számítógéphez való hozzáférés. Ráadásul az online tevékenységek sokszor intimitást igényelnek. A laptopok, tabletek, mobiltelefonok terjedése lehetővé 
teszi azt, hogy a lakáson belül is mobillá váljon az egyén. A lehetőséget ki is használják a fiatalok, a laptopok néha itt, néha ott vannak letéve, pl. a nappaliban a tévé előtt.

„Nálunk nagy a család. Több laptop is van. Van a bátyámnak egy saját külön bejáratú, a másikon meg hárman osztozunk a testvéreimmel, megy is rajta állandóan a veszekedés. Meg van egy asztali számítógép a hallban, ami zavaró, mert ha leülök a géphez, akkor mindig járkál valaki a hátam mögött." (21éves, light multitasker lány)

„Nálunk egész kicsi korunk óta van internet, belenôtt a család a gépezésbe. Most ötünkre van három számítógép, de kevés, kell, hogy mindenkinek legyen saját gépe. Öcsém blogot ír, húgom beszélget, édesapám, édesanyám alkotásra használja. Kikerülhetetlen, hogy mindenkinek legyen saját gépe." (18 éves, heavy multitasker fiú)

A fentiek alapján elmondható, hogy a fiatalok médiafogyasztása mind az adott médium előtt-mellett eltöltött idő, mind a fogyasztás gyakorisága mentén lényegesen különbözik ${ }^{95}$ - sok esetben az uralkodó sztereotípiákkal meghazudtolva - az idősebb korosztályokétól. Az egyes médiumokkal töltött idő generációs töréspontjai sok esetben a húszas éveik második felében járóknál (2012-ben a harmincas éveik elején) találhatjuk. Ez nem véletlen, ez ugyanis az a korosztály, ahol a legtöbbek esetében megtörténik a munkaerőpiaci integráció, másik oka valószínűleg a családalapítás következtében megváltozó fogyasztói szokások és igények. De egészen biztosan létezik kohorsz-hatás is, ami alapján elkülönülnek a húszas éveik végén járóktól a mai tizenévesek, akik már a digitális kor értékvilágát és szocializációját hordozzák.

\footnotetext{
95 Mivel a médiafogyasztás mennyiségének kapcsolata a korral nem minden esetben lineáris, ezért a vizsgálat a lineáris regresszióelemzés módszertanán alapul ugyan, de azzal a specifikációval, hogy a magyarázó kor változót két évenként dummyztuk, kivéve 14-17 évesek mivel őket tekintjük a „mai fiataloknak", ők jelentették a kutatás számára a referenciacsoportot, illetve a 80 felettiek, akik túl kevesen vannak a kétéves bontáshoz. A vizsgálatból megtudjuk, hogy átlagosan hány órát használják az adott médiumot „a mai fiatalok”, illetve a többi korcsoport mennyivel és milyen irányban tér el ettől, illetve, hogy ez az eltérés tekinthető-e statisztikailag szignifikánsnak.
} 


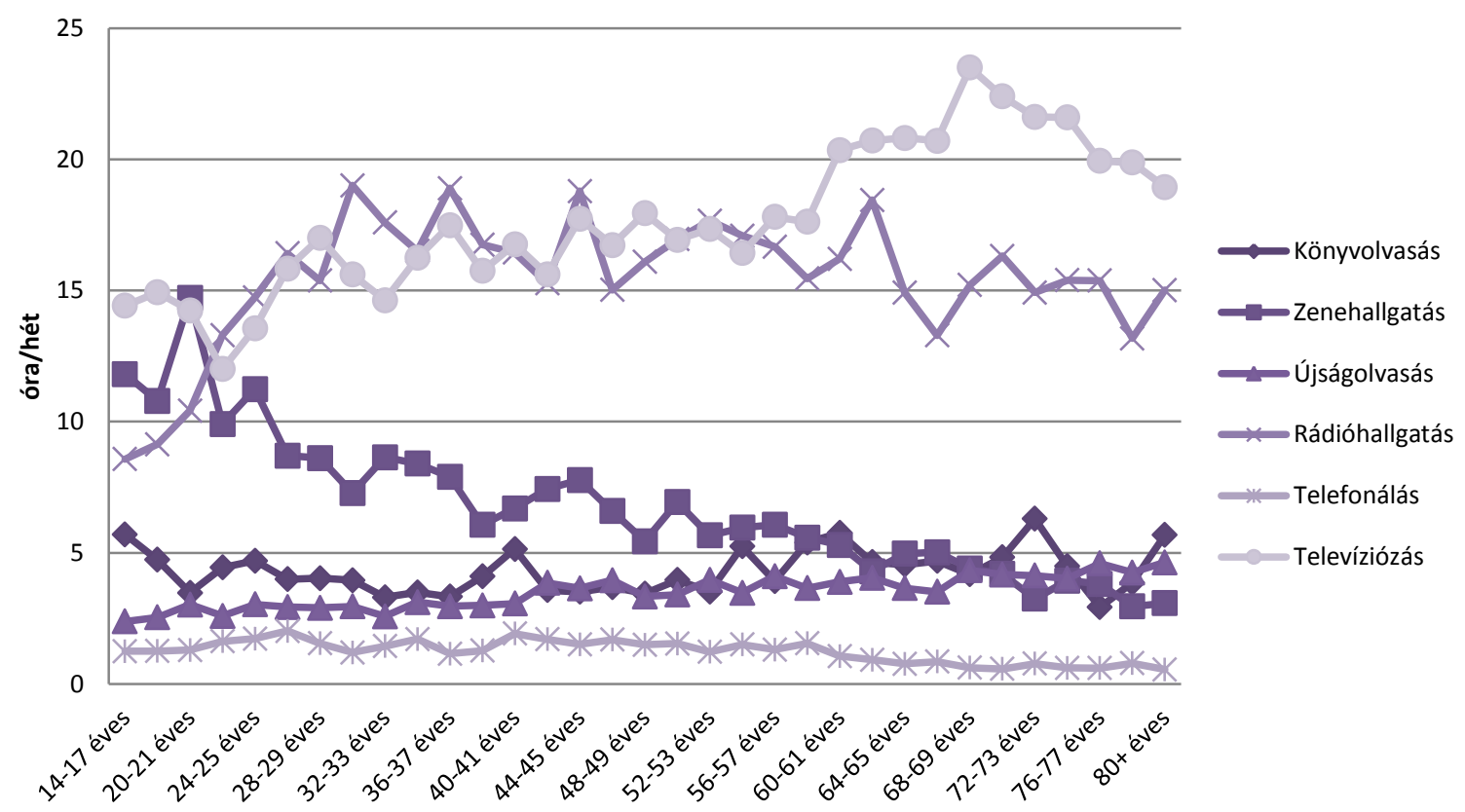

Az egyes médiumok (vélt) fontosságának megítélése különbözik az életkor szerint: a fiatalok az egyes médiumok, elsősorban az internet fontosságát másképp látják, mint az idősebbek. A hagyományos médiumok fontosságának megítélésében megfigyelhető, hogy azok a médiumok, amelyeket a fiatalok az átlagoshoz képest fontosabbnak tekintenek (pl.: könyvek és magazinok), az idősek esetében az átlagoshoz képest kevésbé fontosak, illetve fordítva, a fiatalok által kevésbé fontosnak tartott médiumok (pl.: televízió, rádió), az idősek szemében fontosabbak. Ha a meglévő képbe beemeljük az internetet is, egyrészt azt láthatjuk, hogy megítélésének kapcsolata szinte tökéletesen lineáris a korral, másrészt a fontos-nem fontos dimenziót az életkor alapján többékevésbé változó (hagyományos) médiumok megítélésének szövevényét szó szerint keresztülvágja. Tehát az internet megítélése az életkor alapján sokkal szélsőségesebb, mint a hagyományos médiumoké, a fiatalok sokkal fontosabbnak tekintik az internetet, mint az idősebbek. 

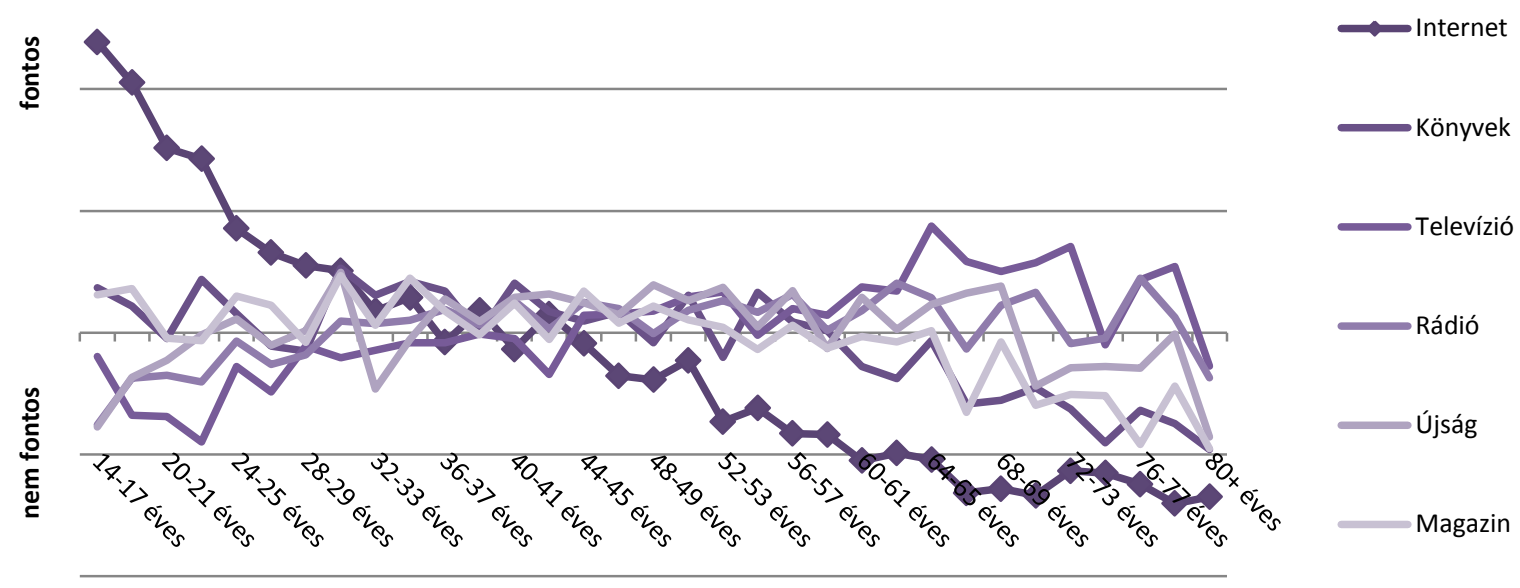

A Budapesti Corvinus Egyetemen végzett fókuszcsoportos kutatásunk a fentieket megerősítő fő tanulsága, hogy a vizsgált 14-23 éves korosztály számára ma már az internet az elsőszámú médium és kommunikációs közeg. A tizen- és huszonévesek médiafogyasztásáról beszélgetve minden csoport esetében az internet volt a központi fogalom, volt olyan eset is, ahol a beszélgetés résztvevői rögtön az internetre asszociáltak a kérdés hallatán. Az internet valóban központi szerepet tölt be a fiatalok életében, (sok) mindent a neten keresztül intéznek (tanulás, egyetem, szórakozás, ügyintézés). Mindegyik fókuszcsoportból kiderült, hogy az internetnek központi szerepe van a fiatalok életében, mindenkinek viszonylag sokféle tevékenysége köthető az internethez, ebből adódóan sokat is interneteznek, bár a mennyiség egyénenként változó lehet - ráadásul maguk a résztvevők is hangsúlyozzák - hogy a fiatalok különböznek az internet előtt töltött idő és az internethez kötődő elfoglaltságok tekintetében. Az internet az elsőszámú médium, emellett kommunikációs célokra is tökéletesen megfelel. „Mindenki azzal kezdi, hogy bemutatkozik, és megmondja, hogy mi az e-mail címe, xy@hotmail.com vagyok”, mondja egyikük. 
„Elmentünk bulizni, megtudtam a nevét, majd otthon gyorsan rákerestem iWiW96-en, ez tipikus. Majd látom, hogy nincs barátnője, bejelöljem-e, aztán bejelölöm, és jön a feszültség, hogy visszajelöl-e. Aztán meg, hogy felvesz-e MSN-re." (17 éves, heavy multitasker lány)

Elmondható, hogy a fiatalok életében az internet az első számú kommunikációs felület, hiszen sokkal jobban ki tudják magukat fejezni pl. az MSN-en, vagy a közösségi szájtokon, amelyekből rengeteg van. Talán egy kivétellel az összes résztvevőnek van MSN címe, és akinek nincs, attól is elvárják a barátai, hogy legyen, csak a testvére még nem készítette el neki a címet.

„Az MSN olyan, mint a chat, csak sokkal jobb, mert itt a barátaiddal vagy együtt." (21 éves, light multitasker lány)

„Ha szervezünk egy bulit, nem is szeretem telefonon (szervezni), hanem MSN-en szervezem. Nem szoktam sokat, meg eleve csak olyanokkal MSNezek, akiket ismerek, nem szoktam így ismerkedni." (21 éves, light multitasker fiú)

Összességében úgy találják, hogy a korosztályukba tartozó fiatalok gyakori médiafogyasztók, „sokat és rendszeresen” interneteznek, számítógépeznek. Az internet előnye, hogy mindent egyesít, a tévét, a rádiót, a videót, az újságot. Minden egy helyen van, ez kényelmes és gyors. Az összegzésnek is beillő véleményt egy budapesti lány fogalmazza meg: Főleg az internet elterjedt, rádió kevésbé, inkább a saját zenei stílusát hallgatja mindenki, „a tévé kezd háttérbe szorulni, de még mindig ott van”.

„...a net ma már lételem gyakorlatilag. Egy idő után, ha nem használom, mert, pl., nyaralok, akkor elkezd izgatni, hogy mi történt, hogy ki írt, hogy ki vett fel iWiW-en. Ezek mára beépültek az ember mindennapi életébe.” (17 éves, heavy multitasker lány)

\footnotetext{
${ }^{96} \mathrm{Az}$ iWiW látványos növekedését, majd zuhanását követően mára (2012) egy lassan fogyó felhasználói táborral bíró közösségi oldallá vált. A fiatalok már évekkel ezelőtt váltottak a Facebook-ra, ami az iWiW-et és más szolgáltatásokat is (e-mail, azonnali üzenetküldők) is teljesen kiszorított az életükből.
} 


\begin{abstract}
„Most fordult elő, hogy nem tudtam leülni egy másfél hétig, és akkor jött egy nap, hogy akkor most inkább nem írok angol leckét, de leülök és megnézem az e-mailjeimet." (17 éves, heavy multitasker lány)
\end{abstract}

Többen egyetértenek azzal, hogy a média által nagyon befolyásolható a korosztály és főleg a fiatalabbak. Nem néznek meg mindent, nem néznek utána a dolgoknak. Hallanak, olvasnak valamit és elhiszik; mindent elhisznek a médiának, és fel sem merül bennük, hogy lehet, hogy nem igaz, mert kényelmesebb elhinni. Médiumokon keresztül informálódnak, felhasználói a médiának, de csak kevés dolog érdekli őket mélyebben, a közügyek meg pláne nem. „Az én generációmból senkinek még csak gőze sem volt róla, hogy át fogják építeni a várost”, meséli az egyik szentendrei fiú.

A fiatalok számára ugyanolyan bejáratott forgatókönyve (módja, szokása) van annak, ahogy leülnek internetezni, mint a filmekben, ahol a reggeli újság mellé legtöbbször „jár” a kávé és a fürdőköpeny. Legtöbbjüknek automatikusan bejelentkezik a csevegő program (ami szinte kizárólag az MSN), ellenőrzik az e-mailjeiket, meglátogatják a közösségi oldalakat, hogy megnézzék „történt-e valami”, ellátogatnak a kedvenc portáljaikra, amelyek az érdeklődésükhöz kapcsolódnak, és gyakran úgy járnak, hogy észre sem veszik mennyi idő telt el, ahogy az egyik huszonéves lány mondja „azt veszem észre, hogy már három órája ülök a gép előtt".

Az életkori és generációs sajátosságokkal kapcsolatban megfogalmazott hipotézis vizsgálatának szempontjából elsődlegesen fontos fiatal korcsoportok elérhetőségét biztosító korábbi WIP adatbázisok közül a legutolsót, a 14-17 évesek adatait is tartalmazó 2007-es hullám adatait alaposabban vizsgálva megállapíthatjuk, hogy a megfogalmazott hipotézisek részben igazolhatónak bizonyulnak. A fiatalabb korcsoportokban, ahogy azt a 2009-es adatok alapján is sejthettük szignifikánsan magasabb az internetezés közben más tevékenységet végzők aránya. A módszertani fejezetben részletezett regressziós modellek segítségével megvizsgálva az internetezés közbeni multitasking életkori jellegzetességeit megfigyelhetjük, hogy a 14-17 évesek multitasking viselkedésétől szignifikánsan eltér a 30-31 évesek, vagy idősebbek viselkedése. Gyakori szimultán tevékenységek esetén ez már a 25-26 évesek korcsoportjában is megfigyelhető ${ }^{97}$. Másik oldalról megközelítve a problémát

\footnotetext{
${ }^{97} \mathrm{~A}$ hatvanas éveikben járók, vagy idősebbek nem a trendbe illeszkedő adataira egyszerű magyarázatot ad az a tény, hogy a felmérés idôpontjában a 60 év felettiek korosztályában alacsony az internetet használók
} 
megfigyelhetjük, hogy a gyakori párhuzamos tevékenységet folytatók átlagéletkora 29 év, ami alig különbözik a csak „néha” 32 évétől, ugyanakkor jelentősen különbözve az ilyen tevékenységet nem folyatatók 38 éves átlagéletkorától.

Mindezek alapján elmondhatjuk, hogy az internetezés közbeni multitasking életkor szerinti összefüggései hasonlóan alakulnak a médiafogyasztás vizsgálata során megfigyeltekkel. Az alábbi ábrán is jól látszik, hogy noha az életkori csoportokban változatosan alakul a párhuzamosság mértéke a trendvonal egyértelmű irányt mutat. Az életkor és a multitasking egyszerű lineáris modelljéből kiolvasható, hogy az életkor hatása jelentős, a megmagyarázott hányad torzítatlan becslése (Adjusted R Square) 23 százalék, míg az életkorcsoportokkal dolgozva 25 százalék, ami úgyszintén megerősíti a multitasking és az életkor közötti kapcsolatot.

33. ábra: Internetezés közbeni multitasking jelenléte az egyes korcsoportokban (N=1338; WIP, 2007)

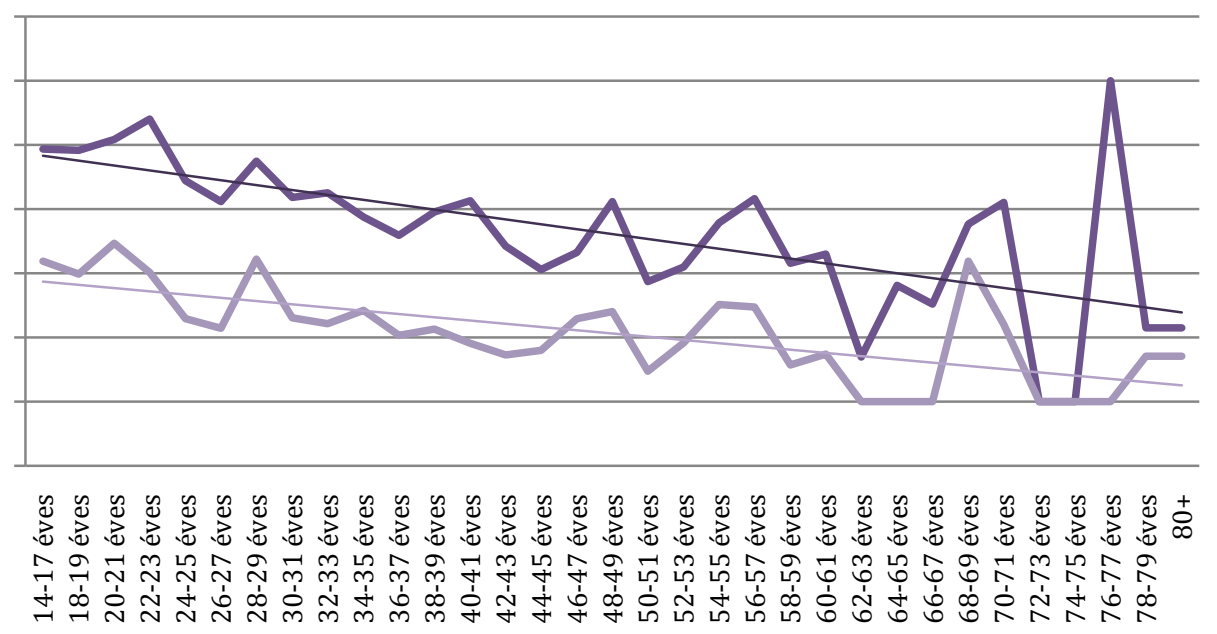

Multitasking (gyakran+néha) _ Gyakori multitasking

A 2008-as online kutatás adatainak felhasználásával a multitasking gyakoriságát egy összesített multitasking indexben $\left(\mathrm{MI}_{0-100}\right)^{98}$ foglaltam össze, amely tartalmazza mind az online-offline, mind az online-online multitaskingot. Az indexet a különböző szociodemográfiai jellemzők szerint megvizsgálva a következő eredményekre juthatunk: A legerősebb magyarázóerővel az életkor bír, azaz minél fiatalabbakat kérdeztünk annál gyakoribb a szimultán tevékenység. Továbbá megfigyelhető egy választóvonal a 20-21

aránya - mindössze 50 internetezőt találunk ebben a korcsoportban - ezért nagyobb kilengések lehetségesek, hiszen egy-egy korcsoporton belül csupán néhány esetből számítódnak ki a statisztikák. ${ }^{98} \mathrm{Az}$ index létrehozásának pontos menetét lásd a módszertani fejezetben. 
éves korcsoport körül. A 21 évesnél idősebbeknél szignifikánsan kisebb az önbevalláson alapuló multitasking, mint a 20 alattiak korcsoportjaiban. Korábbi, fentebb már idézett kutatás (Pintér-Székely, 2006) megállapításait figyelembe véve csak részben meglepő ennek a korosztálynak a megjelenése. Ezek alapján a médiafogyasztásban megmutatkozó generációs töréspont a média multitasking esetében is korábbra tolódik ugyanazt a 15-17 éves referenciacsoportot tekintve.

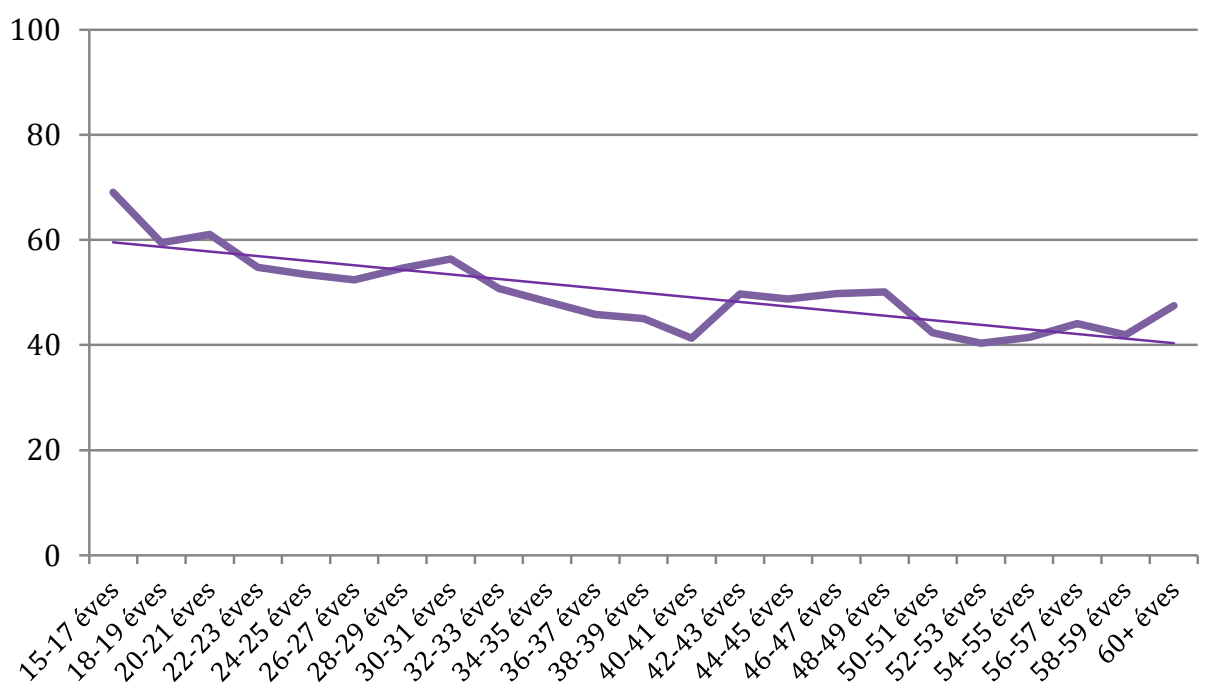

A fenti ábrára pillantva ugyanakkor könnyedén megállapítható, hogy az életkor és a párhuzamos fogyasztás között lineáris kapcsolat van, amelyet megerősít az F-statisztika is, mindez az életkori hatásra utal, azaz ellentmondani látszik a generációs jellegnek. Fontos azonban emlékeztetnünk magunkat arra, hogy ezt a kutatást online lekérdezéssel, internetezők között végeztük.

A generációs, illetve életkori hatásra vonatkozó hipotézis vizsgálatához - mint minden hipotézis vizsgálatához - alkalmazható módszereket alapvetően meghatározza az adatok természete. A rendelkezésre álló adatok elsősorban az Y és az azt megelőző generációk közötti töréspont(ok) feltárását teszik lehetővé, ha valóban léteznek ilyenek. Az utolsó 14-17 éveseket is felmérő World Internet Project adatfelvétel 2007-ben készült el, amelyben a legfiatalabbak a 1993-ban születettek voltak, a 2009-es adatfelvételben már csak a 18 éveseket és annál idősebbeket kérdezték. A Kutatópont 
által gondozott rendszeres nagymintás - kifejezetten a médiafogyasztási szokásokra vonatkozó - kérdőíves kutatás legfrissebb hulláma 2012 őszén készült el, ami azt jelenti, hogy a legfiatalabb résztvevő korosztály 1994-ben született, a Magyar Ifjúság 2012 célcsoportjában a legfiatalabb évjáratba tartozók 1997-ben születtek.

Az egyes adatbázisokban három különböző szempont szerint is el lehet az elemzést végezni, így:

- a médiafogyasztás mennyisége szerint;

- az egyes médiumok fontosságának (információ és szórakozás) megítélése szerint;

- a multitasking gyakorlása szerint.

Az egyes kutatásokban nem mindegyik szempont elemzésére van lehetőségünk, ugyanis nem minden esetben történt teljes körű lekérdezés. A médiafogyasztás mennyiségére és a médiumok fontosságára vonatkozó kérdésblokkokat mindegyik vizsgálandó adatbázis valamilyen formában tartalmazza, azonban multitaskingra vonatkozó kérdések csak a két legutóbbi kérdőívben (WIP2007, LMK2012 és Magyar Ifjúság 2012) kaptak helyet. Emellett további módszertani megkötéseket is érdemes megfontolnunk:

- a médiafogyasztás mennyiségére vonatkozó kérdések a WIP adatfelvételekben heti médiafogyasztásra kérdeztünk, míg a Kutatópont felméréseiben átlagos hétköznap és átlagos hétvége módszerrel dolgoztunk ${ }^{99}$, továbbá a multitaskingra vonatkozó kérdések is különbözőek voltak ${ }^{100}$;

- míg fentebb a médiafogyasztás átlagos idejét általában csak azokra vonatkoztatva mutattam be, akik valamilyen gyakorisággal fogyasztónak minősülnek, a

\footnotetext{
${ }^{99} \mathrm{~A}$ World Internet Project a következőképpen kérdez: Egy átlagos héten összesen a szabadidejéből mennyi időt (óra, perc) fordít könyvolvasásra, televíziónézésre, stb.? A Kutatópont felmérése a következő technikát alkalmazza: Egy átlagos hétköznap, mennyi időt (hány órát és hány percet) tölt Ön... ? És egy átlagos hétvégén (a két napon együtt), mennyi időt (hány órát és hány percet) tölt Ön...?

${ }^{100}$ A WIP a multitaskingot egy egyszerű egyválaszos kérdéssel közelíti meg: Szokott Ön internetezés közben más tevékenységet is folytatni, például telefonálni, zenét hallgatni, vagy tévét nézni? A Kutatópont felmérése több kérdéssel részletsebben foglalkozik a multitasking jelenségével: Szokott-e Ön számítógépezés, internetezés közben hagyományos módon (nem a számítógépen keresztül) rádiót hallgatni? Szokott-e Ön számítógépezés, internetezés közben hagyományos módon (nem a számítógépen keresztül) televíziót nézni? Milyen számítógépes, internetes tevékenységek esetében jellemző, hogy Ön közben más ugyancsak a számítógéphez kötődő tevékenységet is végez? (Online rádióhallgatás; Zenehallgatás; Játék; Online, vagy tv kártyás tévézés; Böngészés; Azonnali üzenetküldőkön /pl. MSN, Skype/ keresztül történő csevegés; E-mail írás/olvasás; Közösségi oldalak böngészése /pl. iWiW, Facebook/)
} 
generációs hatás megismeréséhez érdemes megfontolni a teljes csoport jellemzését a nem használók „0” értékkel való szerepeltetését;

- a fogyasztók mellett a távolmaradók bevonása az elemzésbe az adott médiummal eltöltött idő átlagára erős hatással van a legfontosabb elem, az internethasználat esetében, ugyanis míg 2001-ben az internetpenetráció 18 százalékos, addig 2007-ben 45 százalékos és 2012-ben 55-60 százalék körüli;

- a Magyar Ifjúság 2012 célcsoportját a 15-29 évesek jelentetik, amely az életkort tekintve jóval szűkebbnek számít, mint a többi felmérés, ezért ennek használata az összehasonlításban alaposan megfontolandó.

Mindezek alapján kétféle módszerrel, az egyes kutatások adatait elkülönített adatbázisokban elemzem és egyesített adatbázissal is dolgozom. Utóbbi megoldás számos módszertani megkötést ${ }^{101}$ eredményez, haszna az egyesített adatbázisok apró torzulásokat kiegyenlítő hatásában és a magas elemszámban (több mint 22 ezer eset) keresendő.

Mindkét felosztásban összesen öt különböző médiummal: az internettel, a könyvekkel, a televízióval, a rádióval és a lapokkal eltöltött idő és ezen médiumok fontosságának kor szerinti megoszlását vizsgáltam meg a kétféle módszer szerint.

A különböző adatbázisokon külön-külön végzett elemzések megmutatták, hogy a vizsgált médiumokkal töltött idő, illetve azok fontossága szinte mindegyik vizsgálatban szignifikáns összefüggést mutat az életkorral, akár egyszerű lineáris kapcsolatról, akár korcsoportonkénti kapcsolatról beszélünk (a részéleteket lásd a függelékben). A különböző időpontban készült kutatások jelzik a médiafogyasztás átalakulását, a hagyományos média térvesztését és az internet felemelkedését. A rádióhallgatás, vagy az újságolvasás folyamatos visszaszorulását láthatjuk az ezredfordulótól napjainkig, míg az internethasználat mennyisége folyamatosan növekedett. Az életkori és generációs hatást tesztelő regressziós modellek magyarázóereje alig különbözik egymástól, a generációs töréspontok nem mutatnak állandóságot, ami főleg annak köszönhető, hogy a kutatások

\footnotetext{
${ }^{101}$ Különböző keresztmetszeti vizsgálatok adatbázisainak egyesítése számos problémát vet fel. Az eltérő módszertan, eltérő célcsoport, eltérő kutatási koncepció olyan problémákat is jelenthet, amelyek hatását becsülni sem vagyunk képesek, másokat akár ki is kerülhetünk, mindenesetre vannak olyan tényezők, amelyekkel kapcsolatban az elemzés előtt döntést kell hozni. Ezek közül a legfontosabb az egyesített adatbázisban a súlyok kezelése, megőrizzük-e az eredeti súlyokat, készítsünk újakat, vagy ne használjunk súlyozást. Mivel az egyesített adatbázis elemzését egyfajta kontrollként használom a súlyozatlan minta mellett döntöttem, amit indokol a különböző időintervallumokban felvett adatok és a társadalom szerkezetének változása közötti ellentét, valamint a különböző életkori metszetek alkalmazása is.
} 
között eltelt idő alatt az életkortól függetlenül is gyökeresen megváltozott a médiafogyasztás.

A különböző, 2001-től napjainkig készült vizsgálatok áttekintése jogosan veti fel azt a kérdést, hogy ha ilyen erős szerepe van az eltelt időnek mennyire lehetnek tartósak a generációs jellemzők. Az összesített adatbázis használatával az is vizsgálhatóvá válik, hogy az évtizednyi időkülönbséggel felvett adatsorok között van-e statisztikailag igazolható különbség, azaz megváltozott-e szignifikánsan a médiafogyasztás a vizsgált jellemzők szerint. Kétutas varianciaanalízisek alkalmazásával választ kaphatunk arra a kérdésre, hogy azonos életkori csoportokban a különböző időpontokban (2001-től 2012-ig) felvett adatokban történtek-e elmozdulások, más szóval különböznek-e egymástól a mai tizenévesek, huszonévesek, stb. a 10 évvel ezelőtti tizenévesektől, huszonévesektől, stb.

A varianciaanalízisek minden esetben szignifikáns kisebb-nagyobb megmagyarázott hányadot képeznek az életkor ${ }^{102}$, illetve az idő103 tekintetében, ami legjelentősebb az internet fontosságának esetében (44 százalék). Jellemzően az életkori hatás tekinthető erősebbnek, elsősorban a zenehallgatás, a multitasking, a tévénézés, valamint a televízió és az internet fontossága tekintetében. Mivel a tévénézés kivételével jókora megmagyarázott hányaddal találkozunk, elmondhatjuk, hogy az életkor szerepe ezekben az esetekben az évek múlásával is megmaradt, míg az internetezés mennyiségében, vagy a hagyományos média fontosságának megítélésében erősebb az idő hatása, azaz adott korcsoportokban az eltelt idő alatt jelentősebbé vált a különbség, mint amely megjelenik az életkor szerint a különböző években készült keresztmetszeti vizsgálatok esetében.

${ }^{102} \mathrm{Az}$ életkor a varianciaanalízisben ötéves korcsoportok szerint került beépítésre (17 kategória: 14-15; 16-20; 21-25; ...; 90+ évesek).

${ }^{103} \mathrm{Az}$ idő az adatfelvételek éve kategoriális változó formájában (négy kategória: 1=2001; 2=2004; $3=2007 ; 4=2012$ ). 


\begin{tabular}{lccc} 
Médiafogyasztás & $\begin{array}{c}\text { Megmagyarázott } \\
\text { hányad (R } \\
\text { Squared) }\end{array}$ & $\begin{array}{c}\text { Életkori hatás erőssége } \\
\text { (Beta) }\end{array}$ & $\begin{array}{c}\text { Idő hatásának erōssége } \\
\text { (Beta) }\end{array}$ \\
\hline Könyvolvasás & 0,01 & 0,08 & 0,05 \\
\hline Újságolvasás & 0,02 & 0,13 & 0,08 \\
\hline Rádióhallgatás & 0,03 & 0,13 & 0,11 \\
Zenehallgatás & 0,14 & 0,37 & 0,03 \\
Tévénézés & 0,05 & 0,24 & 0,05 \\
\hline Internetezés & 0,27 & 0,28 & 0,31 \\
Könyvek fontossága & 0,04 & 0,18 & 0,21 \\
Újságok fontossága & 0,06 & 0,11 & 0,19 \\
Rádió fontossága & 0,07 & 0,11 & 0,20 \\
Televízió fontossága & 0,09 & 0,23 & 0,11 \\
Internet fontossága & 0,42 & 0,44 & 0,31 \\
Multitasking & 0,23 & 0,41 & 0,11 \\
\hline
\end{tabular}

Mindezek alapján kijelenthető, hogy a médiafogyasztás számos tekintetben életkori meghatározottsággal bír, hasonlóan ahhoz, ahogy bírt egy évtizeddel korábban. Ugyanakkor fontos kiemelni, hogy néhány esetben így a print média (könyvek, nyomtatott sajtó), illetve a rádió, vagy az internet vonatkozásában a vizsgált évtized során fontos változás következett be, globálisan csökkent a hagyományos médiumok fontossága és növekedett az online média szerepe.

A megfogalmazott hipotézis vizsgálata szempontjából a fentiek azt jelentik, hogy van értelme az életkor tartós szerepéről beszélni általában a médiafogyasztás tekintetében. A hipotézis vizsgálatát a fentebb már részletezett kétféle regressziós modellel végeztem el, az életkori és generációs hatást a modellek magyarázóerejének összehasonlításával is lehetne vizsgálni, azok között azonban olyan csekély a különbség (lásd függelék), hogy biztonsággal nem jelenthető ki, hogy a generációkat feltételező modell alkalmasabb a médiafogyasztás jellegzetességeinek leírására.

Mindazonáltal az elemzések alapján megállapítható, hogy az életkori hatás mellett erős a generációs hatás is, azaz a fiatalkori internetezési mennyiségek és az internet fontossága rögzül. Az idősebbek (X és Baby boom generáció) számára a nyomtatott sajtó olvasás és tévénézés mennyiségében fedezhetünk fel dominanciát. Az adatok alapján többékevésbé akár igazolhatóak is lehetnek azok a generációs határok, amelyeket fentebb bemutattunk. Az elemzések során kirajzolódni látszanak generációs jellegzetességek, amelyeket a következő táblázatban foglaltam össze: 
22. táblázat: Médiafogyasztási generációk

Generációk

Veteránok

Baby boom nemzedéke

$\mathrm{X}$ generáció

Y generáció

Z generáció

Alfa nemzedék
Generációs határok

1939-1938 előtt születettek

1940-1941 - 1968-1969 között születettek 1970-1971 - 1978-1979 között születettek 1980-1981 - 1991-1993 között születettek 1994-1995 után születettek nem vizsgálható

Az elemzés logikáját megfordítva az is vizsgálható, hogy a fenti csoportosítás jobb megoldásnak tekinthető-e mint más életkori csoportosítással magyarázni a médiafogyasztást. Az összesített mintán végzett varianciaanalízisek csak helyenként (internetezés mennyisége, internet és könyvek fontossága) mutatnak nagyobb magyarázóerőt, mint amit az ötéves életkori csoportok esetében tapasztaltunk, mindebből az következik, hogy az internet járul hozzá leginkább a generációs jelleghez. A párhuzamos médiafogyasztást vizsgáló különböző modellek ezzel szemben nem mutatnak különbséget, így ebben az esetben akár az életkor lineáris hatását is tekinthetnénk elsődlegesnek.

23. táblázat: Életkori és generációs varianciaanalízisek eredménye

Médiafogyasztás

\section{Életkori hatás erőssége az idő hatás kontrollja mellett (Beta)}

Generációs hatás erőssége az idő hatás kontrollja mellett (Beta)

\begin{tabular}{llc}
\hline Könyvolvasás & 0,08 & 0,06 \\
\hline Újságolvasás & 0,13 & 0,10 \\
\hline Rádióhallgatás & 0,13 & 0,11 \\
\hline Zenehallgatás & 0,37 & 0,36 \\
\hline Tévénézés & 0,24 & 0,24 \\
\hline Internetezés & 0,28 & 0,32 \\
\hline Könyvek fontossága & 0,18 & 0,20 \\
\hline Újságok fontossága & 0,11 & 0,11 \\
\hline Rádió fontossága & 0,11 & 0,11 \\
\hline Televízió fontossága & 0,23 & 0,24 \\
\hline Internet fontossága & 0,44 & 0,49 \\
\hline Multitasking & 0,41 & 0,42 \\
\hline
\end{tabular}

$\mathrm{Az}$ összesített adatbázis arra is alkalmas, hogy amolyan kísérletként más megközelítéssel is teszteljük a generációs jelleg erősségét. Az alapkérdést olyan módon is vizsgálhatjuk, hogy úgy tesszük fel, hogy van-e szignifikáns különbség például a 1979ben születettek internetezési mennyisége, a televízió fontosságának megítélése, stb. között, ha a 2001, 2004, 2007, vagy 2012 adatait nézzük? A fentiekből láthattuk, hogy 
minden bizonnyal van, azonban ha azt feltételezzük, hogy ez csupán az idő hatása miatt történhet, úgy egy standardizálást követően a belső struktúrát megtartva az idő hatását minimalizálhatjuk. Születési évenként rendezve az összesített adatbázison végzett egyszerű varianciaanalízisek eredményeként - ahol a függő változót a médiafogyasztásra vonatkozó változók standardizált változatai és a független változót az adatfelvételi hullámok jelentették - több mint háromezer $\mathrm{F}$ statisztikát értelmezve elmondható, hogy a fenti generációs felosztás nem vizsgázott rosszul. A Veteránok generációjában korévenként a vizsgált 13 ismérvből (médiafogyasztás mennyisége médiumonként, médiumok fontosságának megítélése és multitasking gyakorisága) átlagosan két esetben fordult elő, hogy szignifikáns különbség (sig. > 0,01) adódott az egyes hullámok adatfelvételei között, azaz másként viselkedett a vizsgált generáció. A Baby boom nemzedéke esetében ugyanez átlagosan négyszer, míg az X generáció esetében átlagosan háromszor fordult elő, míg a még vizsgálható Y generáció esetében átlagosan hét ilyen alkalmat rögzíthetünk. A Z generáció vizsgálata nem volt lehetséges, ugyanis csupán 2012-es adatok állnak rendelkezésre ezzel a nemzedékkel kapcsolatban így nem volt összehasonlítási alap. Mindez azt mutatja, hogy - az összesített adatbázis módszertani megkötései mellett is - a médiafogyasztásban jelen van a nemzedéki jelleg, hiszen a vizsgált ismérvek szerint - leszámítva az idő globális hatásait - jellemzően nincs szignifikáns különbség a különböző években készült vizsgálatok adatai között, tehát a vizsgált generációk jórészt megtartják a médiafogyasztási jellegzetességeiket. Ez a vizsgálati módszer ugyanakkor arra is felhívja a figyelmet, hogy néhány évvel eltolt generációs határvonalak nagyon hasonló eredményeket hoznak, tehát a pontosabb határok kijelölésére nem alkalmas, vagy ilyen határok nem is léteznek.

A fentiekben a különböző megközelítések szerinti vizsgálatok során láthattuk, hogy az életkor az egyik, ha nem a legfontosabb magyarázója a médiafogyasztásnak, illetve a részletesebben vizsgált média- és kommunikációs multitaskingnak. Konklúzióként elmondható, hogy habár minden bizonnyal van relevanciája a különböző generációs felosztásoknak, azonban a generációs határok meglehetősen bizonytalanok és önkényesek.

A megfogalmazott hipotézisekkel kapcsolatban megállapíthatjuk, hogy részben igazolhatónak bizonyulnak. Részben igazolható, hogy a médiafogyasztás mennyisége és a párhuzamos fogyasztás mértéke szerint is jelen vannak a generációs töréspontok azzal a 
kiegészítéssel, hogy az életkor és a párhuzamos fogyasztás közötti lineáris kapcsolat hasonló mértékben alkalmas a kapcsolat leírására. Az életkori és generációs hatást tesztelő modellek magyarázóereje alig különbözik egymástól, a generációs töréspontok nem mutatnak állandóságot.

Általános tapasztalatként elmondható, hogy minél fiatalabbakat vizsgálunk annál gyakoribb a szimultán tevékenység. A multitasking és az életkor lineáris összefüggésének meredeksége azt is jelzi, hogy a médiafogyasztásban megmutatkozó generációs töréspont a média multitasking esetében korábbra tolódik, így részben igazolható az a hipotézis, miszerint a párhuzamos fogyasztás generációs „határai” nem esnek egybe a fogyasztás mennyiségének generációs töréspontjaival. Ebben az esetben is fontos azzal a kiegészítéssel élni, hogy az életkori hatást tesztelő modellek magyarázóereje hasonló mértékű, ebből adódóan a generációk kijelölése önkényes.

Mindezek alapján részben igazolhatónak tekinthető, hogy a médiafogyasztásban az életkori sajátosságok mellett generációs hatások is érvényesülnek, ami azt jelenti, hogy léteznek olyan, a születési évek alapján meghatározható csoportok (generációk), amelyek médiafogyasztási jellegzetességeiket az évek múlásával is megőrzik. Csupán részben tarthatjuk igazolhatónak, hiszen a megfogalmazott fő hipotézis tartalmát tekintve ugyan igazolható, de a generációs határok bizonytalansága, illetve a lineáris modellek hasonló erősségű magyarázóereje óvatosságra figyelmeztetnek. 


\subsection{A MULTITASKING KOGNITÍV RENDSZERRE GYAKOROLT HATÁSA}

A multitasking tevékenység egyik legfontosabb korlátozó tényezője lehet a figyelem megosztásának nehézsége. A Stanford Egyetem 2009-ben konferenciát szentelt a témának, ahol főként pszichológiai aspektusból mutatták be a média multitasking tevékenységet. A konferencián elhangzó egyik legtöbb figyelmet kiváltó gondolat az volt miszerint a multitasking általában rontja a hatékonyságot - azaz „a többet gyorsabban egyszerre" valójában hosszabb ideig tart - ráadásul általában azok élnek ezzel, akik kevésbé tudják alkalmazni. Az ITTK-NRC berkeiben végzett 2008-as és a Kutatópontos 2012-ben készült kutatásban ugyan arra nem volt lehetőség, hogy ezt a hipotézist objektív módszerrel teszteljük, azonban a felmérés arra a kérdésre kiterjedt, hogy a médiafogyasztók hogyan élik meg, ha azonos jellegű, különböző forrású tartalmakat kell befogadniuk. Az adatok elemzése után elmondható, hogy a kérdezettek legalább fele saját bevallása szerint - problémamentesen viseli ezeket a megterheléseket.

35. ábra: Mennyire megerőltető az Ön számára, ha különböző számítógépes-internetes tevékenységeket (online rádiózás, zenehallgatás, e-mailezés stb.) egyszerre kell végeznie? (N=978; Forrás: ITTK-NRC, 2008)

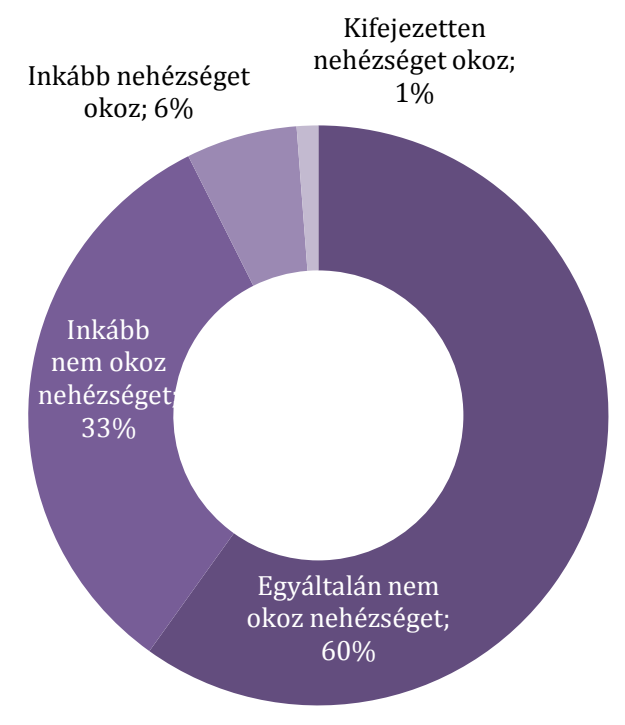

A kérdezettek fele (52\%) saját bevallása szerint soha, vagy csak ritkán veszíti el a fonalat egy-egy televíziós műsor nézése közben, ha a számítógépre is figyel közben. 
36. ábra: Milyen gyakran fordul elő, hogy számítógépezés, internetezés közben a televízión nézett műsornál elveszti a fonalat? (N=610; Forrás: ITTK-NRC, 2008)

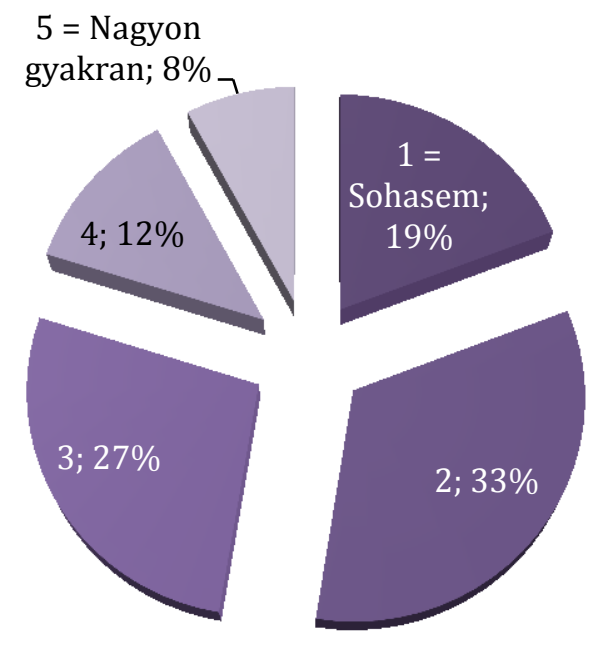

A kérdezettek túlnyomó többsége (84\%) számára legfeljebb kis nehézséget okoz a média multitasking és alig néhányan (2\%) vannak olyanok, akik számára ténylegesen megerőltető tevékenységet jelent.

37. ábra: Mennyire megerőltető az Ön számára a különböző online tevékenységek mellett a televízióra is figyelni? (N=610; Forrás: ITTK-NRC, 2008)

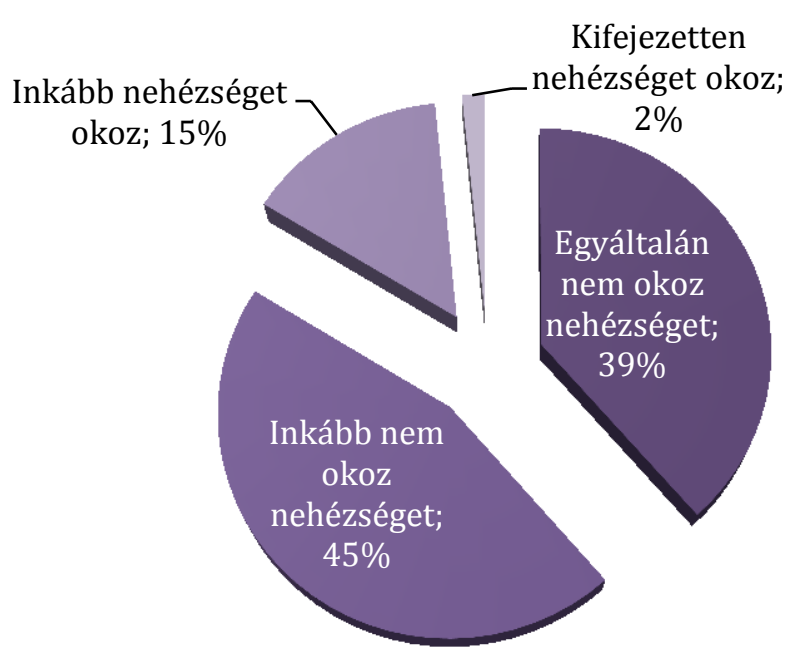

A fenti kérdésekre adott válaszokat megvizsgálva a multitasking index tükrében azt a megfigyelést tehetjük, hogy az internetezők - saját bevallásuk szerint - meglehetősen 
tudatosan fogyasztanak egyidejűleg médiát, ugyanis leginkább azok gyakorolják a multitaskingot, akik számára - saját bevallásuk szerint - kevésbé jelent nehézséget.

38. ábra: Multitasking index a terhelés megítélése szerint (N=610; N=978; Forrás: ITTK-NRC, 2008)

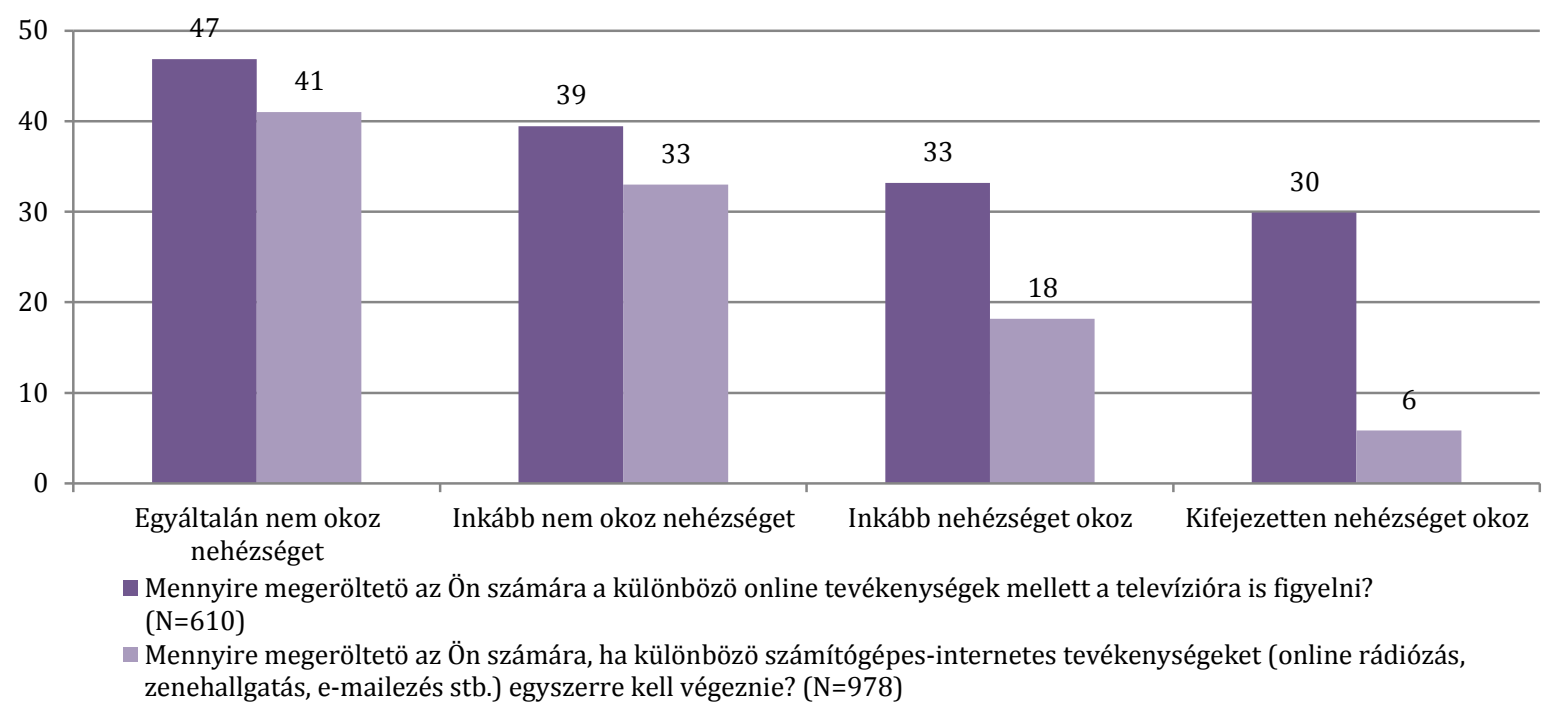

A nemzetközi kutatásokban gyakran alkalmazott, a média és kommunikációs multitaskingot kognitív szempontok szerinti vizsgálva - nem tagadva, hogy a lehetőségeim ebben a tekintetben a nemzetközi kutatásokhoz képest jóval szerényebbek - megállapítható, hogy a fogyasztók szerint a multitasking problémamentes, a figyelmet nem terhelő fogyasztási forma. Visszautalva a kognitív túlterhelést vizsgáló szakirodalomra fontos arra felhívni a figyelmet, hogy a kvantitatív kutatásokban elsősorban a médiafogyasztási tevékenységekre koncentráltunk és kevésbé foglalkoztunk az olyan erőforrás-bővítő tevékenységekkel, mint a tanulás, vagy a munka.

Ezt a hiányt orvosolva a következőkben elsősorban a kvalitatív kutatási tapasztalataimra építve be kívánom mutatni a párhuzamosságot a rekreációs tevékenységek mellett a nagyobb figyelmet igénylő erőforrás-bővítő tevékenységek esetében is. 


\subsection{REKREÁCIÓS ÉS ERŐFORRÁS-BŐVÍTŐ TEVÉKENYSÉGEK}

Fentebb már kitértem a párhuzamos tevékenységek alapvető csoportosítására, amellyel kapcsolatban a rekreációs - főleg médiafogyasztás, és az ehhez tartozó kommunikációs főleg online és mobil kommunikáció, valamint az ezektől alapvetően különböző erőforrás-bővítő - főleg a(z online) tanulás és munkatevékenységek 104 megkülönböztetése mellett érveltem.

Az Információs Társadalom- és Trendkutató Központ (ITTK) valamint az NRC Piackutató együttmúködésében készült 2008-as kutatásban az online-online, tehát a számítógéphez, internethez kötődő tevékenységeket aszerint vizsgáltam, hogy azok végzése közben jelen vannak-e más online tevékenységek. A következő tevékenységekre terjedt ki a vizsgálat:

- Azonnali üzenetküldőkön keresztül történő csevegés

- Böngészés

- E-mail írás/olvasás

- Játék

- Online televízió nézés

- Tanulás és/vagy munka

- Zene- és/vagy online rádióhallgatás

$\mathrm{Az}$ eredmények szerint világosan megfogalmazható, hogy az online párhuzamos tevékenységek (leginkább médiafogyasztás) intenzitása a szórakozás, kikapcsolódás, csevegés (azaz a rekreációs tevékenységek) esetében van jelen, amennyiben komolyabb, nagyobb figyelmet igénylő (erőforrás-bővítő) tevékenységre kerül sor, csökken azok száma, akik másra is figyelnek. Nem meglepő tehát, hogy a számítógéphez köthető rádióvagy zenehallgatás esetén, illetve az azonnali üzenetküldőkön folytatott csevegések közben folytatnak a kérdezettek leginkább más tevékenységeket is. Ezzel szemben, ha tanulásról, vagy munkáról van szó jellemzően nem társítanak hozzá mást.

${ }^{104}$ A felsorolásból hiányzik a társas dimenzió, ahogy fentebb utaltam rá, a tevékenységtipológia ezen részével jelen keretek között önállóan nem foglalkozom. 


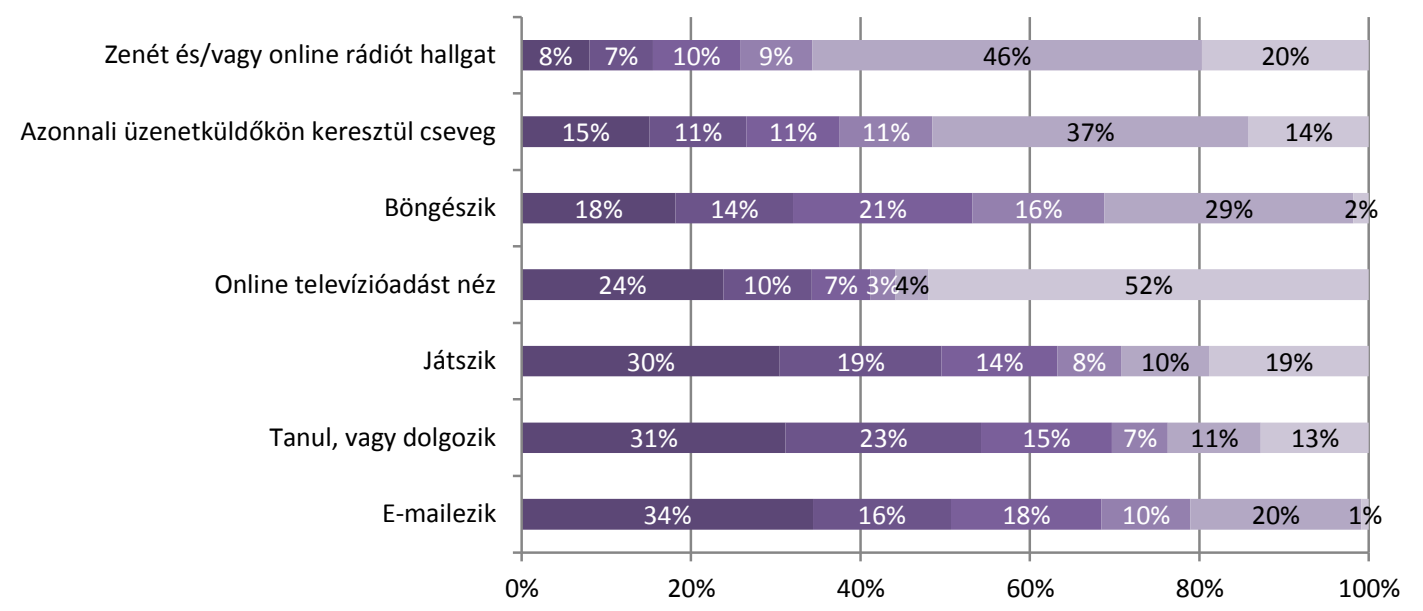

$\square 1$ = Sohasem végez mást ezalatt $\square 2 \square 3 \square 4 \square 5$ = Szinte mindig végez más tevékenységet is $\square$ Egyáltalán nem végzi ezt a tevékenységet

A 8000 15-29 éves fiatal részvételével készült Magyar Ifjúság 2012 kutatásban minden eddiginél részletesebben vizsgáltam az online tevékenységeket szem előtt tartva a párhuzamos fogyasztás kontextuális jellemzői szerinti felosztását: azaz a rekreációs főleg médiafogyasztási tevékenységeket, a kommunikációs tevékenységeket, illetve az erőforrás-bővítést - azaz a számítógéphez-internethez kötött munkát és az online tanulást. A korábban bemutatott empirikus eredményeket megerősítve a nagymintás kvantitatív vizsgálat is azt mutatja, hogy a tevékenység jellege alapján különbözik a multitasking gyakorlata az online környezetben. Megfigyelhető, hogy más tevékenységek elsősorban az online zene- és rádióhallgatás esetén vannak jelen - a tevékenységet folytató fiatalok (a teljes korosztály közel háromnegyede) ötöde (20\%) az idő nagy részében miközben online rádiót, vagy zenét hallgat más tevékenységet is folytat. Az erőforrás-bővítés tevékenységei közben, így a tanulás, vagy a munka esetében ugyanez az arány 6-7 százalék. Ez a különbség arra enged következtetni, hogy a párhuzamosság az egyes tevékenységek jellegétől nem független.

A multitasking hatások összegzésére nem csupán a különböző indexek alkalmasak. A dimenziók csökkentésére, ugyanakkor a lényeges információk megőrzésére - pl. a tevékenységek jellegében lévő különbségek megjelenítésére - alkalmas statisztikai módszer a faktorelemzés, amely a megfogalmazott hipotézisek tesztelésére is alkalmas. A látens struktúrák feltárására gyakorta alkalmazott faktorelemzés a vizsgált hét médiumhoz kapcsolódó multitasking hatásait a rádió- és zenehallgatás mellőzésével 
végül ${ }^{105}$ egy főkomponensbe rendezi, amely a teljes információtartalom valamivel több mint felét (56\%) képes megőrizni.

Az online környezethez kötődő multitasking vizsgálatának esetében is van értelme az MMI index mellett látens struktúrát keresni. Az összesen 10 különböző vizsgált online tevékenység alapján végül106 egy kétfaktoros struktúra stabilizálódott összesen hat ismérv felhasználásával (a játék, a videotartalmak, az e-mail írás/olvasás, illetve a hírek és egyéb szöveges tartalmak olvasása kimaradt a modellből). A két faktor a teljes variancia valamivel több mint felét magyarázza meg (53\%), az első faktor 35 százalék, míg a második 17 százalék magyarázóerővel.

Az elkészített faktoranalízis által feltárt látens struktúra gyakorlatilag igazolja az erőforrás-bővítő és rekreációs tevékenységek elkülönülését.
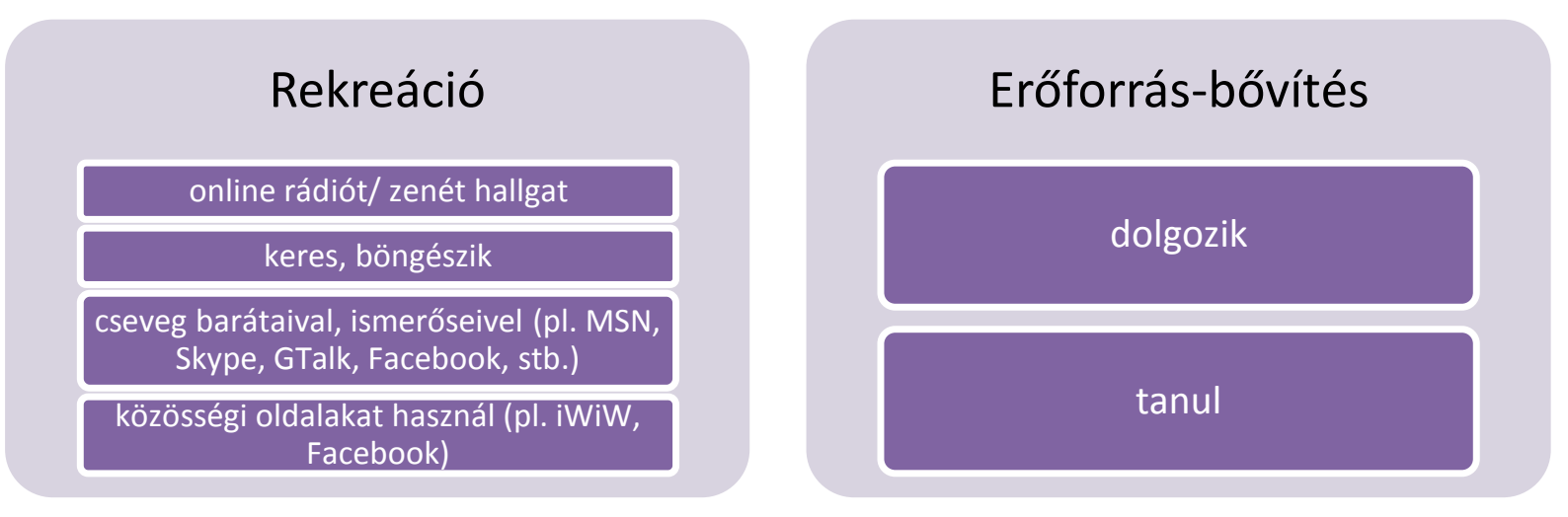

105 A Maximum Likelihood módszert alkalmazó modell első futtatása során két faktort láthatunk kirajzolódni, bár a kommunalitások megfelelnek, azonban a Khi-négyzet statisztika szerint a modell illeszkedése gyenge (Khi: 483,240; df.: 8; sig.: 0,000). A rotált faktorszkórok alapján több változó esetében sem lehet megállapítani egyértelmű illeszkedést a második faktort egyedüliként domináló zenehallgatás $(0,92)$ kihagyását követően már csak egy faktor maradt. Főkomponens analízist folytatva a megmaradt változószetten a rádióhallgatás kommunalitásának meggyengülését figyelhetjük meg $(0,212)$, aminek kihagyása már stabil struktúrát eredményez magas kommunlaitásokkal és faktorszkórokkal.

${ }^{106}$ Akár az általános multitasking faktorelemzésénél megfigyelhettük, esetünkben is az első futtatás két faktort vázolt fel (Maximum Likelihood módszerrel), amelyhez magas Kaiser-Meyer-Olkin érték $(0,915)$ társult, megfelelő kommunalitásokkal. Összességében azonban a Khi-négyzet statisztika szerint a faktorok rosszul képezik le a mért változókat (Khi: 432,512; df.: 26; sig.: 0,000). Logikailag ugyan a rekreációs tevékenységek tovább bonthatóak (kommunikáció és tartalomfogyasztás), azonban a kettőnél több faktorra épülő modellek illeszkedése sem megfelelő. Négy lépésben egyesével kizártam a modellből a leggyengébb kommunlaítással, vagy nem egyértelmű illeszkedéssel bíró változókat, míg a modell illeszkedése érezhetően nem javult (Khi: 19,138; df.: 4; sig.: 0,001). Ugyan ez az illeszkedés korántsem nevezhető ideálisnak ugyanakkor további változók kizárása a modell logikai értékét csökkentené. 
A létrehozott faktorstruktúrát különböző mértékben magyarázzák az életmóddal, élethelyzettel kapcsolatos ismérvek ${ }^{107}$. Habár a Magyar Ifjúság 2012 életkori metszete kizárólag a 15-29 évesekre vonatkozik, mégis találunk szignifikáns összefüggést az egyes korcsoportok és a létrejött faktorok között. Az egyszerű egyutas varianciaanalízisek (one-way ANalysis Of VAriance) közül, bár rendkívül csekély magyarázóerővel a rekreációs faktor esetében találunk szignifikáns modellt108, amely arra utal, hogy minél fiatalabb korcsoportokat vizsgálunk annál gyakoribb az online rekreációs tevékenységek párhuzamossága. Az online erőforrás-bővítő faktor esetében a kor nem alkot szignifikáns magyarázatot.

41. ábra: Erőforrás-bővítő és rekreációs faktorok korcsoportok szerint (N=3025; Forrás: Magyar Ifjúság 2012)

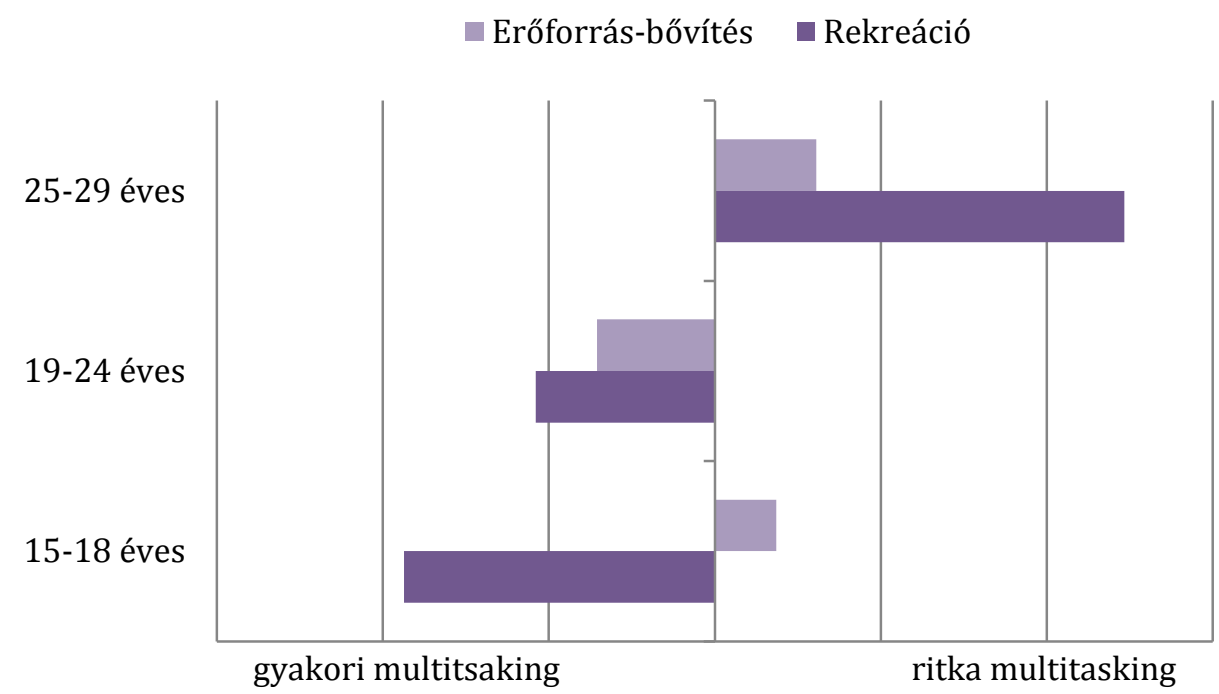

Az életkorhoz hasonló gyenge magyarázóerőt, de szignifikáns kapcsolatra109 utal a jelenleg tanulók - nem tanulók megkülönböztetésével felépített modell, amelyből kiderül, hogy a jelenleg tanulmányokat folytatók körében jellemzőbb a párhuzamosság

${ }^{107}$ A megvizsgált ismérvek közül szignifikáns magyarázatot találunk az életkor, a tanulás, illetve a heti médiafogyasztás összmennyisége esetében, nem magyarázza ugyanakkor a faktorok egyikét sem a nem, illetve az, hogy a kérdezettek végeznek-e jövedelemszerző tevékenységet vagy sem.

${ }^{108}$ A rekreációs online multitasking faktor heterogenitásából a dichotóm változó mindössze 1 százalékot magyaráz meg, amely azonban az F-statisztika 15,883-as értékénél szignifikáns (sig.: 0,000). Az erőforrásbővítő online multitasking faktor 2,454-es F-statisztika értéket produkál, amely nem szignifikáns (sig.: $0,086)$ összefüggésre utal, azaz a nullhipotézist fogadjuk el, miszerint a két változó független.

${ }^{109}$ A rekreációs online multitasking faktor heterogenitásából a háromértékű korcsoport 2,6 százalékot magyaráz meg, amely azonban az F-statisztika 79,785-ös értékénél szignifikáns (sig.: 0,000). Az erőforrásbővítő online multitasking faktor 36,605-ös F-statisztika értéket produkál, amely szintén szignifikáns (sig.: 0,000) összefüggésre utal. 
online tevékenységek esetében, mint azok körében, akik jelenleg nem tanulnak. Az életkor és a tanulás között fennálló interakciós kapcsolatok megjelenítésére is alkalmas kétutas ANOVA modell szignifikánsnak tekinthető az erőforrás-bővítő tevékenységek esetében. Az összefüggés arra utal, hogy a jelenleg tanulók esetében a korábban megfigyelt életkori jellegzetességek iránya megfordulni látszik, vagyis minél idősebbeket nézünk annál jellemzőbb az online erőforrás-bővítő tevékenységek esetében a párhuzamosság ${ }^{110}$. Ez a jelenség könnyedén magyarázható azzal a különbséggel, ami a középfokú és felsőfokú oktatásban résztvevők eltérő tanulási szokásaiban található.

Mindez tehát azt jelenti, hogy a párhuzamosságot tekintve van értelme megkülönböztetni az erőforrás-bővítő és a rekreációs tevékenységeket, ami igazolhatóvá teszi a fô hipotézist, miszerint a párhuzamosság mértékének fontos magyarázója a tevékenység jellege: a különböző típusú tevékenységekhez nem azonos intenzitású multitasking társul. Igazoltnak tekinthető továbbá az a kiegészítő hipotézis is, miszerint a rekreációs (média és kommunikációs) tevékenységekben, jelentősebb szerepet kap a multitasking, mint az erőforrás-bővítésben (munka, tanulás).

A következőkben, ezen megállapítások mentén külön-külön mutatom be azokat a részletes eredményeket, amelyeket a média és kommunikációs multitasking vizsgálata során, elsősorban a különböző kvalitatív kutatások során volt alkalmam megtapasztalni és kitérek a másik kiegészítő hipotézis ${ }^{111}$ vizsgálatára is.

\subsubsection{REKREÁCIÓS TEVÉKENYSÉGEK}

A Budapesti Corvinus Egyetemen végzett fókuszcsoportos kutatás tapasztalatai szerint a célcsoportba tartozó fiatalok (14-23 évesek) életében a meghosszabbodott tanulási idő miatt a legfontosabb tényező, amely beosztja a napjukat, leginkább a tanulmányokhoz (egyeseknél a munkához) kapcsolódik. Általában az idejüket szinte teljes egészében aktívan kihasználják. A fiatalabbaknak, akik még nem dolgoznak, gyakorlatilag az iskolán

\footnotetext{
${ }^{110}$ A kétutas ANOVA esetében az interakció F-statisztikája 3,647-es értékénél szignifikáns (sig.: 0,026), ahol az életkor magyarázata valamivel gyengébb mint a tanulásé (Beta: 0,097 vs. 0,163).

${ }^{111} \mathrm{~A}$ különböző tevékenységek során megfigyelhető multitasking tevékenységek a legtöbbször nem spontán alakulnak ki, hanem tervezettek, tudatosak, az egyén stratégiájától függnek.
} 
kívül minden (egyeseknél az iskola is) kikapcsolódás. „A kikapcsolódás nálam aktív pihenés" mondja az egyik 18 éves férfi, a heavy multitasker csoportból. Az elfoglaltságok hosszú sorából adódóan nagyon kevés az az idő, amit ténylegesen rekreációval töltenek.

A tizenéves média és kommunikációs multitaskingot gyakran űző csoport esetében, többen későn este (7-8-ra) érnek haza. Idejüket strukturálják a nem feltétlenül iskolához kötődő formális szervezetek-programok (edzések, szakkörök, fakultációk). A legtöbben hétvégeken is elfoglaltak. Kérdés nélkül többen megemlítik, hogy hazaérve általában számítógépeznek, sőt panaszkodnak is, hogy gyakran alig marad idejük a gépezésre.

A huszonévesek csoportjaiban többen keresnek munkát, így nekik több szabadidejük van, amibe azért belecsúszik a munkakereséssel töltött idő. A szabadidő eltöltésének lehetőségei között az egyik leggyakrabban említett tevékenység az internetezés „ $A z$ internet kikapcsol” - mondja egy budapesti végzős főiskolás lány, emellett ugyanilyen fontosnak tűnik a barátok-haverok csoportja, akikkel el lehet menni valahova beülni egy sörre, megnézni egy filmet, stb. ahogy az egyik 16 éves lány (internetező) mondja: „Pörgök egész nap. Ha otthon vagyok, gépezek, beszélgetek a nővéremmel, tévézek. De általában nem vagyok otthon."

\section{Párhuzamos médiafogyasztás és kommunikáció az interneten}

A Budapesti Corvinus Egyetemen végzett fókuszcsoportos kutatás beigazolta azokat a várakozásainkat, hogy a fiatalok kihasználják a technológia nyújtotta lehetőségeket és az internet segítségével egyszerre több kommunikációs térben vannak jelen, emellett multimédiás tartalmakat fogyasztanak. A fókuszcsoportos beszélgetések alapján megállapítható, hogy a fiatalok életében a zene, valamint az internetes csevegés ${ }^{112}$ a leginkább űzött olyan tevékenység, ami mellé más online aktivitás is kapcsolódik. A beszélgetéseken résztvevő fiatalok nem pusztán saját szokásaikról, hanem a korosztályukról is hasonlóan nyilatkoztak. Azt tapasztalják, hogy a barátaiknál is abszolút ugyanígy megy (több program megy egyszerre, az MSN, és a zene folyamatosan).

${ }^{112}$ A 2007-es adatfelvételnél ez leginkább az MSN messenger szolgáltatását jelentette, amely ma már bizonyára a Facebook csevegő szolgáltatása váltott fel. 
A fókuszcsoportos beszélgetésekből kiderült, hogy a kommunikációs és média multitasking leginkább az internethez (és a számítógéphez) kötődik. A fiatalok, miután bekapcsolták a számítógépüket, először ellenőrzik, hogy ki van online, ki hagyott üzenetet, mi történt a kedvenc oldalakon. Olyan természetes ez, mint amikor az ember hazaér, megnézi ki van otthon, mi van a postaládában. A gép bekapcsolása után a többség egyszerre több alkalmazást is futtat.

„Sokféle alkalmazást használok egyszerre: MSN, rádió, ha hallok a rádióban olyan zenét, akkor keresőprogramok és zeneletöltés. Mivel emellett még képeket is szerkesztgetek, sok (kb. 20) ablak van megnyitva." (17 éves, heavy multitasker lány)

Nem csupán az eredeti besorolásunk alapján (azaz, hogy gyakorolja-e a multitaskingot), hanem kor szerint is találhatunk különbségeket, sőt ezek erősebbnek tűnnek. A tizenéves multitasking csoportba tartozók jellemzően több ablakot (több programot) jelenítenek meg egyszerre.

- MSN, kereső oldalak, blogok, zene (de „rádió nem, nálam konkrét zenék mennek”)

- zene mindig, zeneletöltés, 1-2 játék közben, MSN (jó pár ablak), blog, szótár, kereső

- mindig van zene, e-mail, képszerkesztő programok

Ugyanennek a korosztálynak azon tagjai, akik nem gyakorolják a multitaskingot

- e-mail, iWiW, és mellette MSN és a zene.

- tevékenységtől függ, pl.: ha képet szerkeszt, akkor csak azzal foglalkozik, maximum MSN fut mellette

- minden megy - MSN, kereső, film (DVD), TV (párhuzamosan, hiszen minden a gépen van)

A huszonéves multitasking csoportban összességében kevesebb alkalmazást említettek, mint a fiatalabb csoportokban, többen voltak, akik mindössze két dolgot említettek.

- böngésző (Firefox), zene, MSN vagy Skype, letöltő program.

- MSN, Winamp, internet rádió 
A huszonéves kontrolcsoportban hasonlóan, a huszonéves multitasking csoporthoz csak néhány dolgot említenek (a többség hármat) általában szűk keresztmetszet a gép teljesítménye, mert bizonyos alkalmazások együttes használatakor lefagy a számítógép.

- E-mail és az iWiW egyszerre meg van nyitva. Nem nyit meg sok oldalt egyszerre (nincs értelme, és lefagy a gép tőle, vagy lassabb tőle, meg nincs is rá szükség).

- MSN közben megy általában valami (pl. YouTube).

- MSN, zene, e-mail/közösségi oldal, közben letöltés

Vannak, akik számára a zene nem mindig összeegyeztethető más elfoglaltságokkal, habár legtöbbször szól, de vannak olyan esetek egy-egy olyan feladat, amikor erősen kell koncentrálni, ilyenkor a zenét lehalkítják, vagy teljes csendet igényelnek.

A fókuszcsoportos beszélgetések közben arra is volt lehetőség, hogy a multitaskinghoz kapcsolódó attitűdökről is némi képet kaphassunk. Általános tapasztalat, hogy a fiatalabbak pozitívabban viszonyulnak az egyszerre több tevékenységhez. Ez nyilván annak is köszönhető, hogy köztük találjuk meg azokat, akik a legkreatívabban képesek a kommunikációs tevékenységüket és médiafogyasztásukat összeilleszteni. A legextrémebb szokásokkal rendelkező résztvevő a következőképpen fogalmaz:

„Nagyon sok mindent tudok egyszerre csinálni, annyit hogy az már sokkoló.” (15 éves, heavy multitasker fiú)”

„Több dolgot csinálok, azt élvezem. Tudok egyszerre beszélni és MSN-ezni. Egy dolog unalmas. Minden, megy, nem áll az élet, hanem pörög." (16 éves, heavy multitasker lány)

Vannak azonban olyanok is, aki szerint kevésbé lehet egyszerre több tevékenységet végezni és nem is szokták gyakorolni ezt. Ahogy az egyik tizenéves lány fogalmaz „Én inkább elmerülök magamban, és csak egy adott dologra koncentrálok, pl. a rajzra." A huszonéves internetezők csoportjában hasonló vélemények hangzanak el. „Csak MSN-nel lehet ezt megoldani, amíg várok, hogy válaszoljon, addig megnézek valami mást. De egyszerre nem lehet két cikket olvasni."- mondja egy 21 éves, internetező férfi

A huszonéves multitasking csoportban a résztvevők meg is egyeznek abban, hogy teljes értékében csak egy dolgot lehet befogadni, ami azt jelenti, hogy a figyelemmegosztás esetében mindig vannak olyan információk, amelyek elvesznek. Van, aki szerint inkább 
attól függ, hogy az ember agya hogyan müködik. Van olyan például, akinek a zene inspirálja az agyát, de van, akinek elvonja a figyelmét.

A fókuszcsoportos beszélgetésből kiderült, hogy bár egyénenként különbözőképpen lehetséges a kommunikációs és média multitasking, mégis léteznek olyan tevékenységek (alkalmazások), amelyek jól megférnek egymás mellett és akadnak olyanok is, amelyek kizárják egymást. A fiatalok számára a leginkább összeegyeztethető internetes tevékenység az instant messengeren való kommunikáció. („MSN-nel bármit lehet kombinálni. Bármi, amit csak nézel.") A beszélgetéseken résztvevő fiatalok szerint majdnem minden más tevékenység mellett lehet csevegni, különösen hatékony különböző csoportos feladatoknál, ahol keresés eredményét gyakran továbbadja az ember.

„Nem nagyon van olyan két egymással jól harmonizáló dolog, csak akkor, ha van közöttük tartalmi kapcsolat pl., egy film elözetes, és hozzá egy kritika, vagy van egy blog, ami mellé egy adott zene kapcsolódik." (18 éves, heavy multitasker fiú)"

Az instant messengerek mellett talán a zene az egyetlen, amely általánosan jelen van internetezés közben, ahogy ezt egy huszonéves fiú megfogalmazza: „ha internetezek, akkor valaminek szólni kell".

Az azonnali üzenetküldők és a zene sokszor jól megfér egymás mellett „szeretik egymást”, ahogy egyik tizenéves lány mondja. Nem is okoz túlságosan nagy nehézséget több dologra figyelni, hiszen mindenki számára megszokott, „valószínűleg, ha nehézséget okozna, nem így csinálnánk" mondja egyikük. Esetenként az is előfordul, hogy a multitasking nem feltétlenül hatékony.

„A gép nagy teljesítményü, így attól függ, hogy mennyi mindent csinálok egyszerre, hogy mennyire bírom." Állítása szerint nagyon jó bírja, hogy sok mindent csinál egyszerre, de ha novellát ír, akkor viszont semmi más nincs, „ha valaki lélegzik a sarokban, azt megölöm” ez egyfajta transzállapot, csak arra koncentrál. A rajz mellett viszont kifejezetten jó, ha sokfelől jön az információ, ezeket az információkat szereti összegezni a rajzaiban. Ilyenkor a zene is jó szokott lenni. (17 éves, heavy multitasker fiú) 
„...ha valami zenét hallgatok, és szöveg van benne rengeteg, és figyelek a szövegre, akkor lehet, hogy négyszer neki kell futnom, hogy értelmezzem azt, amit MSN-en írnak". (15 éves, heavy multitasker fiú)

Abban nagyjából mindenki egyetért, hogy a mai fiatalok körében népszerű az internethez köthető multitasking, bár egyéntől függ, de nagy általában, mindenki „pörög” és több dolgot csinál egyszerre. A kognitív túlterhelés fogalma mentén kíváncsiak voltunk arra, hogy hol van a befogadás határa. Arra kérdeztünk rá, hogy hány emberrel lehet egyszerre csevegni az interneten?

A fizikailag befogadható „csevegési mennyiség” nem különbözik lényegesen attól, hogy ki mennyire gyakorolja a multitaskingot, a kor alapján azonban van különbség. A tizenévesek 8-10 különböző beszélgetésben látták a befogadás határát, ami rendre a huszonévesek duplája. Természetesen vannak extrém esetek is:

„... volt már, hogy 30 ablak ment egyszerre. El tudtam igazodni köztük, de nem kívánom senkinek. Kb. másfél éve volt, hogy rendesen fent voltam, azóta rejtve kapcsolódok. Megrohannak, hogy ez kell, meg az kell, töltsd le ezt, írd ki DVD-re azt." (15 éves, heavy multitasker fiú)

A huszonévesek esetében nagyjából öt ablakban folyó interakció követhető, csak „rossz”, „nehéz”, „zavaró”, „megterhelö". „Nem azt írom, amit akartam” - mondja egyikük.

A többablakos csevegés egyben azt is jelenti, hogy főtevékenységgé válik, amely a teljes koncentrációs kapacitást lefoglalja.

„Ha sok (8) emberrel MSN-ezek, és ez aktív, akkor mellette nem lehet mást csinálni”, nem is szívesen kezd ilyenkor bele másba. (17 éves, heavy multitasker lány)

„Ha egyszerre nyolc emberrel beszélgetsz, képtelenség mellette mást csinálni". (16 éves, light multitasker lány)

A kvalitatív tapasztalatok alapján a két legfontosabb tevékenység a zenehallgatás és a csevegés bővebb vizsgálatra is érdemes. A Kutatópont 2012 tavaszán online módszerrel végzett 1000 fős, a 18-69 éves magyar népességre reprezentatív kérdőíves kutatásában 
lehetőség volt a zenehallgatás körülményeit alaposabban megvizsgálni. Az eredményekből látható, hogy a zenehallgatás a legritkább esetben tekinthető önálló tevékenységnek. A kérdezettek harmadára (33\%) egyáltalán nem jellemző és további közel felére (46\%) alig jellemző, hogy úgy hallgat zenét, hogy közben nem végez más tevékenységet.

42. ábra: Tevékenységekhez társuló zenehallgatás (N=1000; Forrás: Kutatópont, 2012)

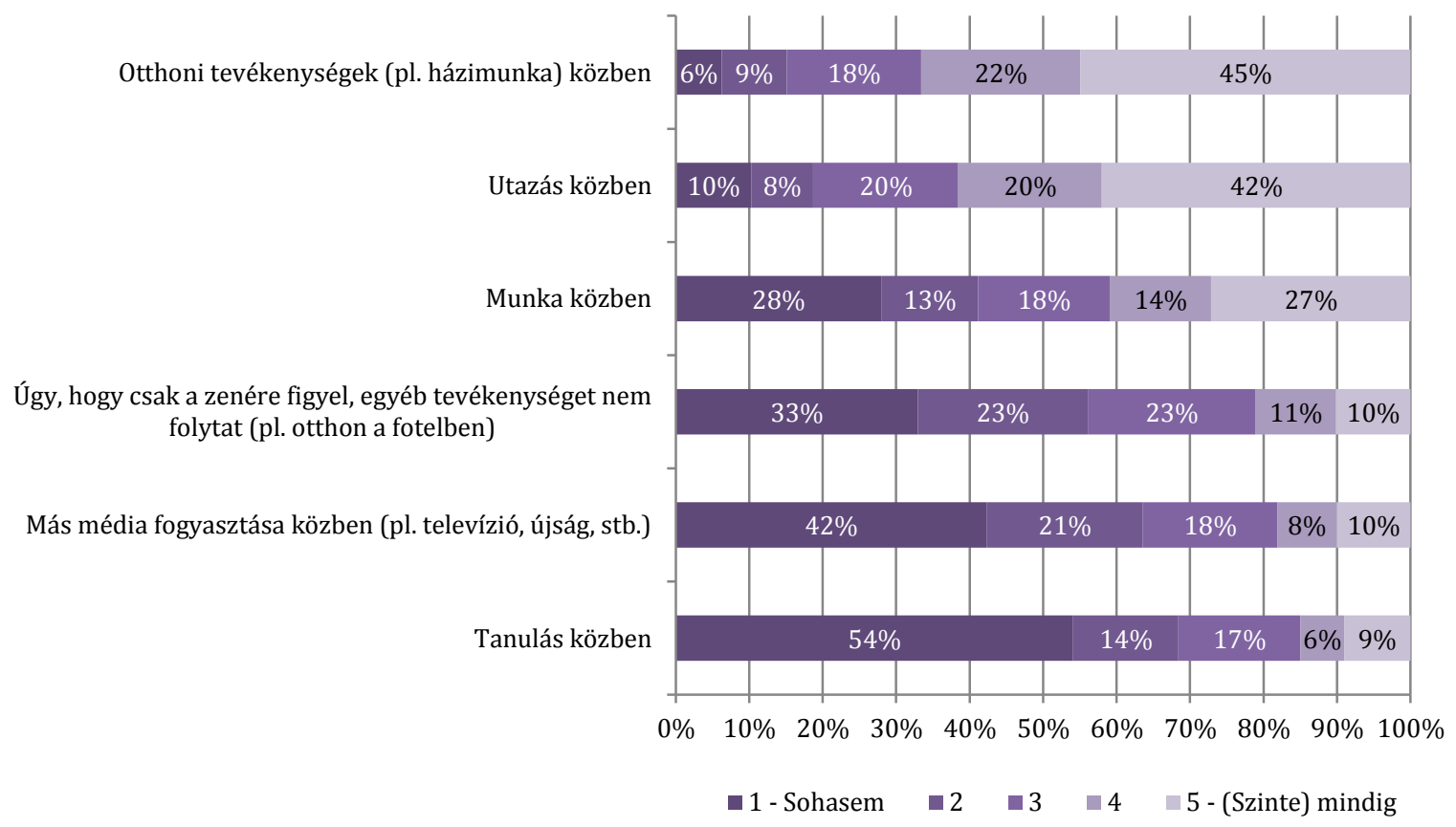

A kérdőíves kutatásból kiderül, hogy a zene felsorolt tevékenységek közül leginkább az otthoni feladatokhoz, pl. a házimunkához kötődik, a megkérdezettek kétharmada (67\%) gyakran (az ötfokú skála 4-es, 5-ös értékei) szokott zenét hallgatni otthoni tevékenységei közben. Hasonlóan magas arányokat (62\%) találunk az utazás közbeni zenehallgatás esetében. Sorban a következő leggyakoribb zene mellett végezhető tevékenység a munka, amelyet a kérdezettek kétötöde (41\%) gyakorol sűrűn. Figyelemre méltó, hogy míg a munka mellé a kérdezettek kétötöde számára gyakran társul zene, addig a tanulás esetén ez az arány csupán 15 százalék.

A csevegésre vonatkozóan az ITTK és az NRC közreműködésében, 2008-ban készült online kutatás szolgál empirikus adatokkal. A 15-17 évesek adatait is tartalmazó online kérdőíves kutatásból kiderül, hogy az internetezők ötöde (21\%) szokott azonnali üzenetküldő szoftvereket használni. A használat legfontosabb tere a kérdezettek otthona 
és legfontosabb célja a magánbeszélgetés. Megfigyelhető ugyanakkor az otthoni munkához, tanuláshoz kapcsolódó használat is, amit a munkahelyen, iskolában személyes kapcsolattartás célú használat, majd a munkahelyi, iskolai munka, vagy tanulási célú használat követ, azonban ezek nem érik el az otthoni magánbeszélgetésekre jellemző gyakoriságot. Mindez igazolja azt a tevékenységtípusbeli besorolást, amely a rekreációs jellegű tevékenységekhez sorolja az online kommunikáció ezen válfaját.

43. ábra: Internetezés közbeni multitasking jelenléte az egyes korcsoportokban (N=121; Forrás: ITTK-NRC, 2008)

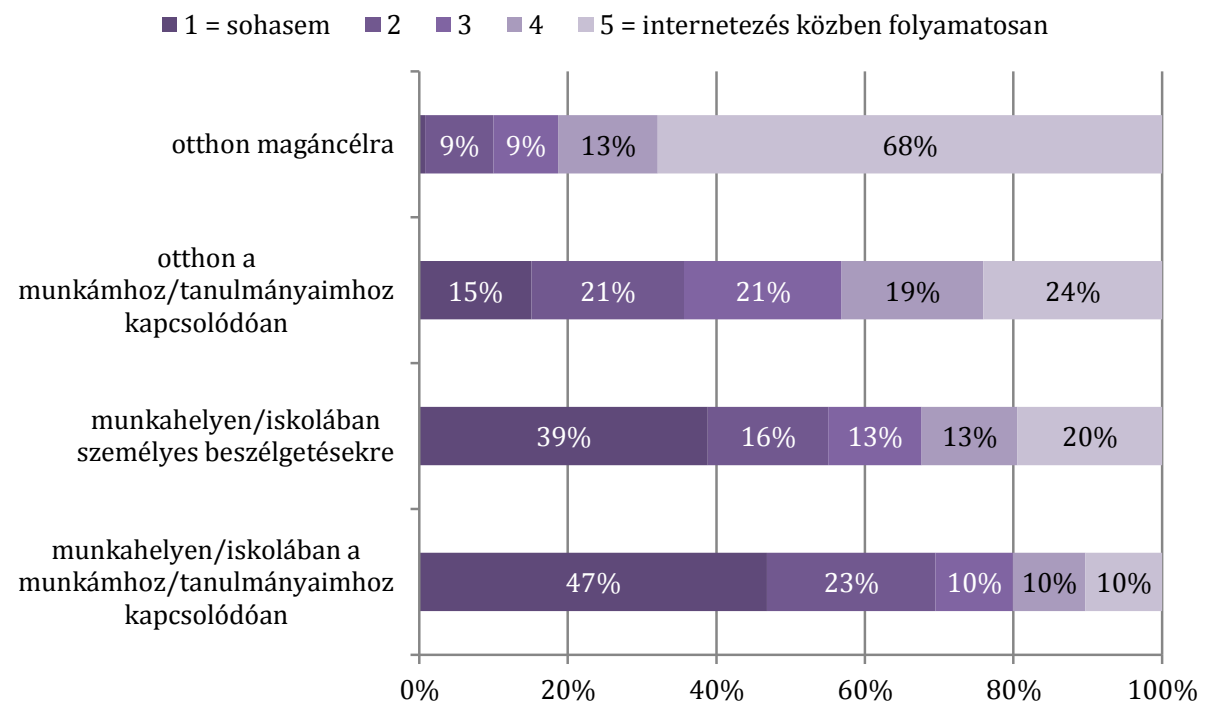

\section{Új és hagyományos média multitasking}

A Budapesti Corvinus Egyetemen készült fókuszcsoportos kutatás során arra is választ kerestünk, hogy vajon azok, akik kihasználják az internetet (számítógépet) mint a multitaskingra alkalmas eszközt becsatlakoztatnak-e hagyományos médiumokat és kommunikációs formákat az internet mellé. Emellett van-e szerepe a hagyományos média világában a multitaskingnak. A következőkben sorra vesszük azokat a kombinációkat, amelyek a négy fókuszcsoportos beszélgetés során előkerültek.

Az internet és a telefon kombinációját szinte mindegyik csoporton említették a fiatalok. Az elmondottak alapján úgy tűnik, hogy a telefon megférhet mind a böngészés mind az online csevegés mellett, bár függ a koncentráltságtól. A többség jól össze tudja egyeztetni ezt a két dolgot. 
„Olyan van, hogy gépezek, és valaki keres telefonon, és beszélek vele, és közben nem szakítom meg azt, amit csinálok. Mi nők híresek vagyunk arról, hogy többfelé is tudunk figyelni. Vagy van olyan, hogy kapok egy e-mailt, és sürgős, és az illető nincs fent a neten, és akkor felhívom.” (21 éves, heavy multitasker lány)

„Tegnap, amikor hívtatok a beszélgetésre épp számítógépeztem. Miközben CS-zek, közben is tudok telefonálni. Van olyan, hogy megy valamilyen film a gépen, közben MSN-ezek, Ventrin beszélgetek, füles a nyakamban (zene) és még a tévét is nézem, ha úgy adódik telefonálok. Rengeteg dologra tudok egyszerre figyelni." (15 éves, heavy multitasker fiú)

„Telefon az igen. De SMS már nem, mert akkor inkább írok neki MSN-en, vagy felhívom, az gyorsabb. Az a kedvencem, amikor küldenek egy SMS-t, hogy gyere fel MSN-re. Volt már olyan, hogy annyira fáradt voltam (MSNezés közben telefonáltam) és azt vettem észre, hogy azt írom le MSN-en, amit mondok a telefonba." (17 éves, heavy multitasker lány)

Érdekes, hogy vannak olyanok, akik számára a telefon különleges értékkel bír, amelyet nem tud helyettesíteni a Skype, vagy az IM hanghívása. „Van egy barátnőm, aki nem ért annyira a géphez, és akkor szoktam neki segíteni, úgy, hogy mindketten a gép elött vagyunk, és közben telefonálunk" - mondja az egyik tizenéves lány. Egy másikuk ki is fejti, hogy miért preferálja inkább a telefont, mint az MSN-en a hanghívást. „Jobb a telefon, ez megszokás is. Jó érzés, hogy fogom meg minden, személyesebb, van hangom." Többen nem is használják MSN-en a hanghívást, sem a Skype-ot, a telefon olyan természetes, egy félórás beszélgetést is inkább ott intéznek el, mint az interneten, ahol mindig ingyenes.

Habár az internetezés és a telefonálás is aktív figyelmet igényel mégis többen tartják összeegyeztethetőnek, mint a televíziót és a telefonálást. Az internetezés a csoportos beszélgetések alapján sokkal inkább individuális tevékenységnek tűnik, mint a tévézés. a

„Nálunk a TV családi dolog, és ezért nem szoktam ilyenkor telefonálni, hogy ne zavarjak vele másokat. Inkább elmegyek, annyira nem érdekel a TV, hogy ne tudjam otthagyni." (17 éves, heavy multitasker lány) 
„TV mellett nem nagyon van más, fóleg nem lehet mellette telefonálni, mert akkor egy idő után ezt kezdem el mondani, amit hallok.” (17 éves, heavy multitasker lány)

Az internetezés és a tévézés többeknél fizikai korlátokba ütközik, ahogy egyikük mondja: „tévét nézni nem tudok netezés közben, mert másik helységben van”.

Azok közül, akik megtehetnék, hogy párhuzamosan használják előfordult, hogy valaki híradót nézett laptoppal a kezében, vagy internetezés közben gyöngyöt füzött és közben a televízión nézett egy filmet, azonban a legtöbbször csoporttól és korosztálytól függetlenül hiába megy a TV, nem oda koncentrálnak.

„Régen volt, hogy öcsém mellettem tévézett, de elromlott a TV, és nem volt értelme megjavítani. Fölösleges, teljesen kizártam akkor is a tévét. Nem érdekelt, csak hangok maradtak meg. Minden információ a géprōl jön, mindent azon keresztül intézek." (17 éves, heavy multitasker fiú)

A zene mivel aktív figyelmet nem igényel, ezért talán a legalkalmasabb arra, hogy más főtevékenységekkel párhuzamosan végezzék, azonban ez leginkább a géphez kötődik és csak abban az esetben van külön forrása, ha valamilyen okból nem lehetséges médialejátszón lejátszani. Azokban a csoportokban, ahová a multitaskingot nem gyakorlók kerültek a más forrásból származó zene is sokkal kevésbé van jelen.

„Zenét csak akkor hallgatok, ha nincs meg gépen, mert pl. bekrepál a gépen a CD lejátszó, és akkor külön." (17 éves, heavy multitasker lány)

„A rádión a zene jó, de ha jön a reklám, ha beszélnek, az is kizökkent. Nincs értelme, hogy együtt menjen több dolog, mert zavaró." (21 éves, light multitasker lány)

A fókuszcsoportokon résztvevo fiatalok szemében az olvasás olyan tevékenység, amely mellett legfeljebb a zene fér meg, de az esetek többségében még az sem. A fiatalok nagyrészt egyetértettek abban, hogy nem lehet olvasni, ha más tevékenységet is végez az ember, az olvasás nem olyan, mint amikor a TV előtt az aznapi műsort megnézzük, esetleg főzés közben lehet olvasni, de azt is csak egyes esetekben 
„Az olvasás mindentôl távol van, akkor semmi mást nem csinálok, csak a könyvre figyelek." (16 éves, heavy multitasker lány)

„Ha olvasok, akkor kuckó, akkor megszûnik a világ.” Ebben a helyzetben nincs értelme zenét hallgatni, „föleg, ha komoly dolgot olvasok, olyat, amit én választottam, ami engem érdekel. Ilyenkor úgyse hallanám a zenét.” (17 éves, heavy multitasker lány)

„Ha órákig kavargatós a téma, akkor kiviszem a könyvemet a konyhába és olvasom." A könnyedebb múfajok mellett (folyóiratok, magazinok) már megjelenik a zene. (21éves, light multitasker lány)

\subsubsection{ERŐFORRÁS-BŐVÍTŐ TEVÉKENYSÉGEK}

\section{Infokommunikációs eszközhasználat és multitasking tanulás során}

Mélyebb elemzést tesz lehetővé a Tükörterem Társadalomkutató Műhely iskolai kutatása. Az oktatók és szülők számára az egyik legfontosabb kérdés, hogy a számítógép előtt eltöltött idő vajon a tanulás rovására megy-e, vagy épp a hasznára válik. Az adatok alapján úgy tűnik, hogy a rosszabb tanulók többet interneteznek, viszont a kapcsolat a mennyiség és a félévi átlag között nem olyan erős (0,3-as korrelációs együttható, a szülők által becsült mennyiség esetén 0,2). Mindez azt jelenti, hogy nem olyan erős az az állítás, hogy a monitor előtt eltöltött idő mennyisége és a tanulmányi eredmények összefüggenek. Megjegyzendő, hogy csupán tizedes jegyekben mérhető különbséget találunk az átlag és a saját gép tulajdonlása között, holott a saját gép megduplázza a számítógépezés-internetezés mennyiségét ${ }^{113}$.

A diákok majd háromnegyedének (72\%) van saját számítógépe, míg a többiek rendszerint szüleik gépét használják. Természetesen a saját eszközzel rendelkezők

\footnotetext{
${ }^{113}$ A saját géppel bírók féléves átlaga 4,4, a mások (leginkább a szülők) gépét használók átlaga 4,5. Mivel a diákok féléves átlagai igen magasak, így ez esetben relatív különbségtételt alkalmazunk, azaz a 4,1-es vagy ez alatti átlaggal rendelkezőket értelmezzük rossz tanulóként, a 4,2-4,5 átlaggal rendelkezőket közepes tanulóként, a 4,6-4,8 közöttieket jó tanulóként és a 4,9, vagy a felettieket kitűnőként. Ezzel a felosztással vizsgálódva már találunk említésre érdemes összefüggést, amely szerint a legalább jó tanulók heti négy órával kevesebbet töltenek a gép előtt, mint az átlag, a közepesek két órával többet, míg a rossz tanulók heti hat órával többet bámulják a monitort.
} 
sokkal intenzívebb használónak bizonyulnak, közel kétszer annyit - 19,5 órát használják hetente, mint azok, akik szüleik $(11,4 \%)$ vagy testvérük $(8,5 \%)$ gépét veszik igénybe.

A számítógépezés-internetezés lehetséges céljai közül a kutatásban a következő tevékenységcsoportokat vettünk figyelembe:

- a tanulással, iskolával kapcsolatos dolgokat (pl. házi feladat, dolgozat stb.)

- a játékot (offline és online)

- a közösségi tevékenységeket (chat, iWiW, MSN, e-mail, Facebook, fórum stb.)

- a szórakozást (zenehallgatás, filmnézés stb.)

A kutatásunkból kiderült, hogy elválik egymástól a tanulás (és a játék) ${ }^{114}$, illetve a szórakozás-közösségi tevékenységek csoportja - utóbbit sokkal gyakrabban végzik, míg a géphez kapcsolódó tanulás és játék ritkább. Figyelemre méltó, hogy meglehetősen összecsengenek a diákok és a szülők válaszai, ami arra utalhat, hogy a szülők eléggé jól ismerik gyermekük számítógépezési-internetezési szokásait. A páronkénti korrelációt vizsgálva rendre erős (0,6 körüli) kapcsolatot találunk a szülők és gyermekeik válaszai között, kivétel ez alól a tanuláshoz kapcsolódó használat, amelyet - az alábbi táblázatra pillantva is láthatjuk, hogy - a szülők gyakoribbnak ítélnek, mint a gyermekeik.

24. táblázat: Az internetezés célja a diákok és a szülők szerint (Nszülő=754, Ndiák=759; Forrás: Tükörterem, 2010)

\begin{tabular}{|c|c|c|c|c|c|c|c|c|}
\hline & \multicolumn{2}{|c|}{ Tanuláshoz } & \multicolumn{2}{|c|}{ Játékra } & \multicolumn{2}{|c|}{ Közösségi tevékenységekre } & \multicolumn{2}{|c|}{ Szórakozásra } \\
\hline & Diák & Szülő & Diák & Szülő & Diák & Szülő & Diák & Szülő \\
\hline Minden nap & $5 \%$ & $11 \%$ & $18 \%$ & $25 \%$ & $50 \%$ & $48 \%$ & $42 \%$ & $48 \%$ \\
\hline Legalább hetente & $46 \%$ & $41 \%$ & $35 \%$ & $29 \%$ & $33 \%$ & $22 \%$ & $41 \%$ & $22 \%$ \\
\hline Havonta többször & $28 \%$ & $29 \%$ & $9 \%$ & $12 \%$ & $5 \%$ & $8 \%$ & $6 \%$ & $8 \%$ \\
\hline Ritkábban & $19 \%$ & $15 \%$ & $21 \%$ & $19 \%$ & $9 \%$ & $9 \%$ & $7 \%$ & $9 \%$ \\
\hline Soha & $3 \%$ & $3 \%$ & $17 \%$ & $13 \%$ & $4 \%$ & $11 \%$ & $4 \%$ & $11 \%$ \\
\hline Nem tudja & - & $1 \%$ & - & $2 \%$ & - & $2 \%$ & - & $2 \%$ \\
\hline
\end{tabular}

Természetesen a fenti tevékenységek jelentősen különböznek a tanulók különböző jellemzői szerint. Megfigyelhető, hogy a tanulásban, valamint a közösségi tevékenységekben élen járók összességében kevesebbet, míg a „gamerek” több időt

\footnotetext{
114 Jellegében elválik egymástól a tanulás-játék, illetve a szórakozás-közösségi tevékenység. Egy egyszerű korrelációszámítással megállapítható, hogy az „elvárt” összefüggések csak felerészben bizonyulnak valósnak, hiszen míg az online közösségi tevékenység és a géphez kötődő szórakozás között erős $(0,5)$ pozitív összefüggést találunk, addig a várt negatív összefüggés a tanulás és játék között kevésbé igazolható $(-0,05)$.
} 
töltenek a képernyő előtt. Nem okoz meglepetést a különböző tevékenységek és a nem kapcsolata sem. Általánosságban elmondható, hogy a tanulásban a lányok, míg a játékok terén a fiúk bizonyulnak intenzívebb használónak, a szórakozás és a közösségi tevékenységek esetében a nemek harca döntetlenre áll.

25. táblázat: Az internetezés céljai nemek szerint (Nszülő=754, Ndiák=759; Forrás: Tükörterem, 2010)

\begin{tabular}{lcccccccc}
\hline & \multicolumn{2}{c}{ Tanuláshoz } & \multicolumn{2}{c}{ Játékra } & Közösségi tevékenységekre & \multicolumn{2}{c}{ Szórakozásra } \\
\hline & Lány & Fiú & Lány & Fiú & Lány & Fiú & Lány & Fiú \\
Minden nap & $4 \%$ & $5 \%$ & $6 \%$ & $29 \%$ & $53 \%$ & $47 \%$ & $37 \%$ & $46 \%$ \\
Legalább hetente & $52 \%$ & $40 \%$ & $26 \%$ & $43 \%$ & $35 \%$ & $32 \%$ & $45 \%$ & $37 \%$ \\
Havonta többször & $28 \%$ & $28 \%$ & $9 \%$ & $8 \%$ & $3 \%$ & $6 \%$ & $6 \%$ & $6 \%$ \\
Ritkábban & $15 \%$ & $23 \%$ & $31 \%$ & $13 \%$ & $6 \%$ & $11 \%$ & $7 \%$ & $7 \%$ \\
Soha & $1 \%$ & $4 \%$ & $28 \%$ & $7 \%$ & $4 \%$ & $3 \%$ & $5 \%$ & $4 \%$ \\
\hline
\end{tabular}

Évfolyamok tekintetében a tanulásban és a játékban nem találtunk jelentős lineáris összefüggést, a szórakozás-közösség tengelyen az alsóbb évfolyamokban bizonyulnak aktívabbnak a diákok. A tanulmányi eredményekés az egyes géphez kapcsolódó tevékenységek közötti kapcsolatot vizsgálva elmondható, hogy a rosszabb tanulók többet lógnak a hálón, legyen szó játékról vagy szórakozásról, esetleg kapcsolattartásról. A tanulás esetében nem ilyen éles a különbség, bár felfedezhető, hogy a jó tanulók gyakrabban használják tanulásra az számítógépet.

A diákoknak szóló online kérdőívben a tanulással kapcsolatos internethasználatot részleteztük a különböző alkalmazások használatának gyakorisága szerint. Azt találtuk, hogy a felsorolt alkalmazások közül három olyan van, amelyhez a rendszeres használatot társíthatjuk, ezek a következők: keresőoldalak, elektronikus szótárak és a Wikipédia. Keresőoldalakat gyakorlatilag mindenki használ, a legtöbben (79\%) hetente minimum egyszer. Hasonlóan általános a Wikipédia használata, bár kevésbé gyakran kapcsolódnak hozzá a radnótis diákok, azért legalább hetente több mint minden második (56\%) tanuló látogatja az oldalt. Az elektronikus szótárak is közkedveltségnek örvendenek, a kérdezettek közel kilenctizede (88\%) használ elektronikus szótárat, és valamivel több mint minden második (53\%) legalább hetente ellátogat ilyen oldalra, vagy megnyitja a gépére telepített szótárprogramot. 
44. ábra: Tanulással összefüggő tartalmak fogyasztási gyakorisága (N=759; Forrás: Tükörterem, 2010)

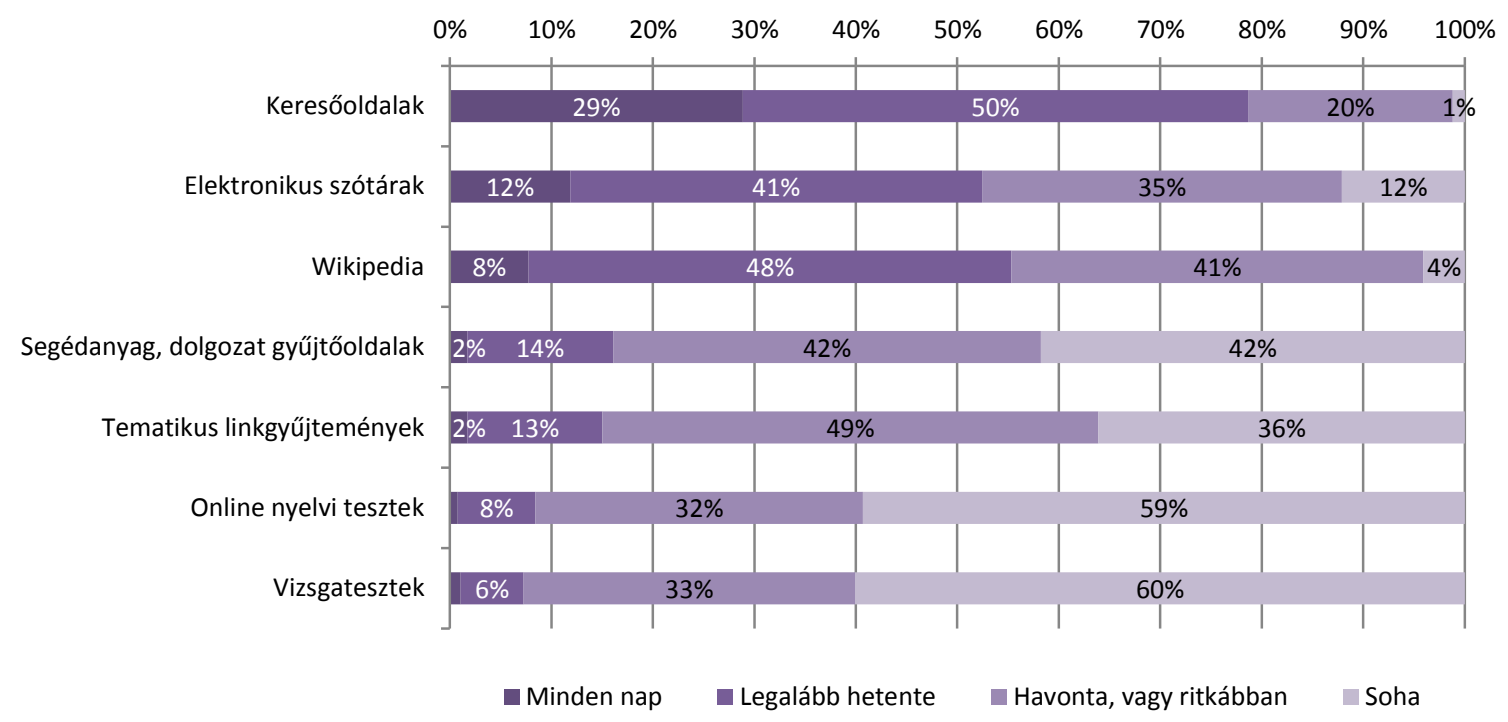

A többi kérdezett oldalt/alkalmazást két részre lehet bontani a többség által - bár ritkán, de - látogatott, azonban általánosan nem használt tematikus linkgyűjtemények (pl.: lap.hu típusú oldalak) és a különböző segédanyagokat, dolgozatokat gyűjtő oldalakra, illetve a többség által nem használt online nyelvi teszteket és különböző vizsgateszteket (pl.: érettségi) tartalmazó oldalakra.

A Budapesti Corvinus Egyetemen, 14-23 évesek között késztett kvalitatív fókuszcsoportos kutatás tapasztalatai alapján elmondható, hogy a fiatalok az internet lehetőségeit a messzemenőkig kihasználják. És nem csak kommunikációra (IM, e-mail, közösségi oldalak), vagy szórakozásra (zene, játék, YouTube) használják, hanem az internet a tanulás és a munka fontos eszköze is.

Habár hasonló oldalakat, tevékenységeket említettek meg az egyes csoportokban, mégis akadnak különbségek, amelyeket elsősorban a kor magyaráz. Ilyen összefüggést találtunk a munka (munkakeresés) és a tanulás (tanulással kapcsolatos információkeresés) elválásában: mindkét tizenéves csoportban előjött, mint az interneten végzett tevékenység a tanulás és mindkét idősebb, huszonéves csoportban említették a munkához kapcsolatos tevékenységeket (elsősorban munkakeresés, hirdetések böngészése). 
„Egyre kevesebbet járunk ma már könyvtárba, mert a házi dolgozatok, a prezentációk ma már a netrôl is megcsinálhatóak igényesen.” (22 éves, heavy multitasker fiú)

„A gép állandóan megy, nem ülök ott állandóan, de be van kapcsolva, és ha eszembe jut valami, akkor oda ülök, és megnézem” (pl.: szótárként használja). De nem eszik a gép előtt, „nem vagyok ennyire elfajzott”. (17 éves, heavy multitasker lány)

„Minden nap van legalább fél óra, amit a net elött töltök, válaszolok az emailekre, megnézek egy-két oldalt. Minden nap, tanulok, keresek pár dolgot a netről. Képletekhez nagyon jó. Előbb használom a Google-t, mint egy szótárat, lexikont." (21 éves, light multitasker fiú)

Az erőforrás-bővítő tevékenységekhez kapcsolódó média és kommunikációs multitasking kétségtelenül jelen van a vizsgált 14-23 éves korosztály életében, azonban egyénenként különbözö, nagyon vegyes gyakorlatokat találunk. A tanulás közbeni kommunikációs tevékenységek közül fontos kiemelni az instant messengerek szerepét, amelyek nem pusztán a szórakozáshoz, a barátságok ápolásához nyújtanak újabb felületet, többen is megfogalmazzák, hogy az azonnali üzenetküldőket a tanulás során is előszeretettel alkalmazzák, amely sokkal inkább képes visszaadni a problémamegoldás valódi lefolyását, mint a magányos feladatmegoldás. Számos esetben előfordul, hogy ,a többiektől” (osztálytársak) azonnali üzenetküldőkön keresztül szerzik az információkat (szótárazás, házi feladat leellenőrzése).

„MSN-en kihasználom, hogy jó kapcsolataim vannak”, segítséget kér fordításhoz, megkérdezi a leckét. Olyanokkal tart kapcsolatot, akikkel együtt van egész nap, meg olyanokkal is, akikkel ritkán találkozik. Ez olcsóbb, és gyorsabban is átmennek az információk. „De ha komolyan kell tanulnom, azt nem lehet a gép előtt, akkor bemegyek a szobámba." Vagyis praktikus dolgokra használja, pl. dokumentumok küldése, telefonálás, tanulás. „Ha Wordbe írok esszéket, akkor az MSN-en mindig elfoglalt vagyok, mert az idegesít, ha pityeg, mert közben zenét is hallgatok". Föleg nyelveknél, szótárazásra használja sokat az MSN-t. „De a gépezést el szoktam különíteni a tanulástól, ezért is van az, hogy mostanában egyre kevesebbet ülök a gép 
elött." Két éve, amikor az iskolában minden tanulási feladatot elvégeztek és otthonra már nem maradt, elment otthonról, vagy leült a gép elé. „Most, ha felmegyek a gépre, akkor 70\%-ban információ-keresésre használom, pl., küldd át a tételeket". (17 éves, heavy multitasker lány)

A tanuláshoz kötődő médiafogyasztás tekintetében nem különböztek gyökeresen az előzetes csoportbeosztásunkban heavy és light userek csoportjai. A light userek csoportjában gyakrabban szorul ki a média, amennyiben tanulásról van szó, ha mégis jelen van, valami az leginkább a zene, de az is csak azokban az esetekben, ha nem magas koncentrációt igénylő feladatról van szó. A light userek csoportjában több esetben megjelenik, hogy általában csak egy dologra tudnak figyelni, így inkább nincs jelen a média.

„Ha elméleti dolgot tanulok, akkor semmi, maximum internet, mert sok anyagot neten kapunk meg, és nem szoktam mindent kinyomtatni. Ha gyakorlati dolgokat csinálok, akkor közben hallgatok zenét, nézek filmet." (21 éves, light multitasker lány)

„Ha tanulok, akkor tanulok. Maximum a számítógép megy, de nem megy rajta zene." A gép megy, mert tudja használni a neten a szótárat stb. Tanuláskor kizárólag segítségnyújtásra használja az internetet, mert nagyon el tudja terelni a figyelmét a legkisebb dolog is. „Ha jegyzetelni kell valamit, akkor azt Word-be, mert az sokkal könnyebben kezelhető, könnyebb vele dolgozni, meg jó lehet később puskának is használni, de ha olvasni kell valamit, azt mindig kinyomtatom, mert különben kifolyik a szemem." (22 éves, light multitasker fiú)

„Ha tanulok, akkor jegyzetelni Word-be szoktam, ezért megy a gép, de a zene változó, hogy mennyire zavaró eközben.” Ha valami ilyenkor nem érdekli („nem fog meg engem”), akkor a zene elvonja a figyelmét, ha érdekli az a rész (amiben otthon van, szereti a témát), amit tanul, akkor meg nem. „A TV meg nem megy egyáltalán." (21 éves, light multitasker lány)

A multitaskingot sűrűn gyakorlók csoportjaiban sokkal gyakrabban jelent meg a média tanulás közben is. Erőteljesen megfigyelhető azonban a felhasználók tudatossága, 
esetenként az erőforrás-bővítő tevékenységek, így a tanulás élesen elválasztásra kerülnek más rekreációs tevékenységektől, még a heavy multitasker csoporton belül is, ami azt mutatja, hogy igazoltnak tekinthető az a hipotézis miszerint a különböző tevékenységek során megfigyelhető multitasking tevékenységek a legtöbbször nem spontán alakulnak ki, hanem tervezettek, tudatosak, az egyén stratégiájától függnek.

„Az MSN nálam totál el van választva a tanulástól. Nekem az egy kikapcsolódás, nem is szoktam olyankor tanulásról beszélni. Nekem olyanok az MSN partnereim, akik régi barátok, barátnők, régi osztálytársak, akikkel ritkán találkozom. Csak tanulás után megyek fel, illetve, hogy ha tudom, hogy valaki csak kora délután van fent, akkor felmegyek." (16 éves, heavy multitasker lány)

„A zene mindig háttérzaj, mindig csinálok közben valami. Tanulás közben is szól (trance, vagy komolyzene), kivéve a magyar zene, mert ez eltereli a figyelmemet." (23 éves, heavy multitasker lány)

„Ha érdekel egy film, akkor nem csinálok mást mellette. Ha fontos a dolog (pl. tanul), akkor bármi más elvonja a figyelmet. Ha írok egy dolgozatot, nem nézhetek egy dokumentumfilmet a hegységekröl és a szülők - legalábbis nálam - is azt mondták, hogy tanulás közben nem szabad rádiót hallgatni, mert elvonja a figyelmet, amiben igazuk volt. De van olyan zene, pl. az instrumentális jazz zene, amit lehet tanulás közben is hallgatni." (20 éves, heavy multitasker fiú)

\section{Infokommunikációs eszközhasználat és multitasking a munkakörnyezetben}

Egy az Excenter Kutatóközpont berkeiben, 2011-ben végzett kutatás során fókuszcsoportos technikával tártuk fel az irodákban, infokommunikációs eszközökkel dolgozók szokásait, attitűdjeit. A kutatás célja az infokommunikációs technológiákhoz kötődő használati szokások, vállalati stratégiák megismerése, különös tekintettel a munkahelyen történő, nem a munkához kötődő tevékenységekre vonatkozóan. Összesen négy csoporttal dolgozhattunk, olyanok részvételével, akik közepes, vagy nagyobb 
állami, vagy piaci cégnél, munkaidejük nagy részében számítógéppel dolgoznak. A csoportokba vegyesen szerepeltek nők és férfiak, különböző iskolai végzettségú és különböző korcsoportba tartozó aktív munkavállalók.

Az általános használati jellemzőkre vonatkozó kérdéseinkben azt kívántuk körüljárni, hogy a fókuszcsoportok résztvevői egy átlagos napon nagyjából mennyi időt töltenek számítógép, internet előtt, és ennek általában mekkora része munka. Ha egy hevenyészett átlagot akarnánk számolni, valahol 7 és 9 óra közötti napi gép előtt eltöltött időre jutnánk, azonban ez egyénenként változó, megfigyelhetünk extrém 14-15 órás időket és visszafogott 5-6 órás használatot is. Nagyban befolyásolja ezt az adott munkakör (vannak-e olyan feladatok, amelyek nem kötődnek a számítógéphez), az ember habitusa (mennyire kötődik a technológiához) és ezzel összefüggésben az életkor. Egy egész jól azonosítható törésvonal figyelhető meg a negyvenes éveik közepén járóknál, a fiatalabbak jellemzően „internettel kelnek és fekszenek”, míg az idősebbek több-kevesebb sikerrel igyekszenek koncentráltabban használni az infokommunikációs technológiát, és a használat során leginkább a munkájukra szorítkozni.

„5-6 óra. De én tudatosan nem kapcsolom be otthon. Jobban érdekel egy könyv, egy színház, vagy az, hogy nyáron kimenjek a természetbe. A túlzott technikát nem fogadom el feltétel nélkül. Sok ember ezeket a dolgokat nem tudja megszûrni." (51 éves, főiskolai végzettséggel rendelkező budapesti nő)

„6-8 óra, munkahelyen a munkaidő 80 százalékát, és otthon még 1-2 órát. Meló előtt és után is gépezek. Reggel a felkelés után az első dolog, hogy bekapcsolom a gépet, és hazaérkezve is ez az első. Bele lehet ebbe szokni. Sokszor haragszom magamra, hogy mást is csinálhatnék." (54 éves, érettségivel rendelkező nő)

„Felkelés és lefekvés között folyamatosan. Szeretem a számítógépet, érdekel a hardver is. Az életem nagy része informatika. Ez köt le. Szeretem a munkámat, a gépeket.” (25 éves, középiskolai végzettséggel rendelkező budapestiférfi)

A fókuszcsoportos kutatásunkból kiderült, hogy az infokommunikációs eszközöket használók kivétel nélkül igénylik azt, hogy ezeket a munkán kívül - a munkahelyen - 
magáncélra is használhassák és akik számára ez fizikailag lehetséges - azaz nincs letiltva az internet - ki is használják. Összességében elmondható, hogy a munkavállalók munkaidejük nagy részében (80-90\%-ban) munkához szorosabban, vagy lazábban kötődő tevékenységeket végeznek. Az, hogy ki mennyit egyénenként és a körülményektől függően változik. Egyéni dimenzióban leginkább a lelkiismeretesség mentén találunk különbségeket, vannak lelkiismeretes munkavállalók, akik elismerik a munkáltató érdekeit és vannak, akik minden lehetőséget megragadnak a saját érdekükben.

„A minisztériumban mindent csináltam, már a többiek szóltak rám, hogy ne torrentezzek, de nem érdekelt. Pedig szóltak, hogy ez mégis csak egy munkahely, és ne akarjak torrenten letölteni, mert ebből probléma lehet. Nem titkoltam el, hogy ezt csinálom, megmondtam a kollégáknak is, hogy torrentezek. A mostani munkahelyemen egy számítógép van az információs pultban, ahol hárman osztozunk rajta. Ezt én úgy oldottam meg, hogy bevittem a saját laptopomat, és kértem, hogy kössék rá a hálózatra. Ezt egy hétig hagyták, de aztán mondták, hogy ezt nem lehet, és most el fogják tôlem venni az IP-címet, vagy mit. Az a kifogás, hogy valami külső vírust vihetek be. (27 éves, diplomás nö)

„8 óra a hivatalos munkaidő, de általában én 10 órát dolgozom. Új vagyok itt, azért nem nézek meg olyan oldalakat, amelyek magáncélúak, pl. közösségi oldalakat, vagy a hobbimhoz kapcsolódó oldalakat." [Később bevallja, hogy szokott azért magáncélból is internetezni munkaidő alatt.] „Néha telefonon próbálok netezni sutyiban, ott nézem meg a leveleimet. Szigorúság van a közösségi oldalakkal kapcsolatban. Nálunk nem teljesítménybér van, de teljesíteni kell egy számot, és ha ezt nem teljesítjük, akkor kirúgnak, így inkább a munkával foglalkozom.” (23 éves, diplomás férfi)

„Én nem is értem ezt a maszek-netezést munkaidőben. Nálunk be van kötve, de fegyelem van, rend van, munkára használjuk. Külső cégekkel levelezünk. Annyi munka van, hogy nincs rá idő. Náluk van net, nincs korlátozva, de idô nincs rá. (55 éves, érettségizett nő) 
A magáncélú infokommunikációs eszközhasználatban legfontosabb korlátozó tényezőt a hozzáférhetőség jelenti, tapasztalataink szerint a munkáltatók jó része beépít valamilyen alapfokú korlátozást, de vannak olyanok is, akik még ennél is tovább mennek. Több olyan résztvevő is volt a fókuszcsoportokon, akik adatbiztonsági szempontokból a számítógépükről egyáltalán nem tudnak kapcsolódni az internethez. Ilyenkor a munkáltatók általában biztosítanak olyan gépeket is, amelyek kifejezetten az internetezésre használhatók, ezzel még a lehetőségét is kizárva a képernyőhöz kötődő, nem a munkához kapcsolódó multitaskingnak.

A hozzáférés tiltásán kívül jelen van a megfigyelés, amely történhet szoftveres monitorozással éppúgy, mint annak megakadályozásával, hogy a munkavállaló „kettesben lehessen” a számítógéppel. A megfigyelés régóta alkalmazott hatékony eszköz, amely beszélgetéseink során gyakorta előkerült és érezhetően befolyásolja, hogy mit engednek meg maguknak a munkavállalók. Megjegyzendő, hogy a különböző munkahelyi környezetekhez különböző stratégiák társulnak, vannak olyanok pl., akik az open office negatív hatását emelik ki, őket zavarja, ha több ember egyszerre beszél, nevet hangosan.

„Nálunk betiltották a netet, hogy dolgozzunk, és ne a magándolgokkal foglalkozzunk munkaidőben. Csak két gépen van internet, és ezt csak akkor tudjuk használni, amikor éjszaka is dolgozunk, és nincs olyan sok ember bent. Egyébként csak a munkához lehet használni. Két hónapja húzták ki az internetkábeleket a gépekből, mert látta a fönök, hogy magáncélra használjuk az internetet. Nem szóltak róla, hogy elveszik az internetet, csak egyik nap nem volt net, észrevettük, hogy nem jönnek be az oldalak. Reklamáltunk a fönöknél és azt mondta, hogy azért vették el, mert sokan magáncélra használták. Korábban sem volt annyira intenzív a magáncélú nethasználat, mert sok a munkánk. Csak néhányan hanyagolták a munkát, és ott a munka rovására ment. Ez a fönök fülébe jutott, és elvették. Azt mondták, hogy a magáncélú netezés lelassítja a programot, amivel dolgoznunk kell." (54 éves, érettségivel rendelkező nő)

„Én a fönök mellett ülök, meg nyitott iroda van, úgyhogy 90-95\%-a munka. Meg rá is mehetnek a gépemre máshonnan, hogy megnézzék, hogy mit 
csinálok. Konkrétan nem vettem még észre, hogy figyelik a gépemet, mert én azt nem látom, de figyelhetik. Onnan tudom, hogy figyelhetik, hogy ha valami baj van a gépemmel, akkor úgy javítják meg, hogy távolról átveszik a gépem fölött az irányítást." (26 éves, diplomás nő)

„Nálunk is úgy vannak az asztalok elhelyezve, hogy rálátunk egymás gépére, vagy ha bejön valaki, akkor látja, hogy mivel foglalkozunk, úgyhogy csak disztingváltan, módjával lehet mással foglalkozni munka közben.” (46 éves, érettségizett nö)

A munka közben használt (nem feltétlenül munka célú) alkalmazások szokványosnak mondhatóak: e-mail; iWiW; Facebook; YouTube; híroldalak; hirdetések; csupán egy-két esetben fordulnak elő különlegesebb felhasználási módok, mint a felnőtt tartalmak, vagy a torrentezés.

\section{Kommunikációs tevékenységek}

Jellemzőek a munkahelyi baráti kapcsolatok is, az egymás közti privát beszélgetéseiket gyakran (ha erre lehetőség van) belső chaten keresztül folytatják. Voltak olyan résztvevők, ahol ún. belső messenger szolgáltatás biztosítja, hogy azonnali képet kapjanak kollégáik aktuális tevékenységéről, vagy akár képernyő-megosztásos kommunikációval segíthessék egymás feladatvégzését. Többen használnak külső csevegő-szolgáltatásokat, Skype-ot, vagy közösségi oldalak chat-szolgáltatásait, ahol van, ott - a szabálynak megfelelően - munkaügyekre kizárólag a belső chatet használják. Sok esetben a chat szinte teljesen kiszorítja a telefon használatát, hiszen míg a telefon esetében csak egy dologra lehet figyelni, chatelés közben más feladatokat is el lehet látni, így a multitaskingra jobban alkalmas. Mindemellett kényelmesebb megoldás, időt nyernek vele, másokat nem zavar, privát jelleget ad a kommunikációnak. Az e-mail használat is teljesen köznapi tevékenységnek számít, egyszer-kétszer szinte mindenki belenéz a saját (magán) levelezőrendszerébe.

A közösségi oldalak (elsősorban a Facebook) látogatása is mindennaposnak számít. Van, aki szerint a használat gyakorisága a munkaterheléstől függ, azaz, ha munka van, akkor 
nem foglalkoznak ilyesmivel, azonban ha éppen ráérnek, akkor előszeretettel nézelődnek. Más alapvetően két típust különböztet meg: azokat, akik napjában egyszer használják, tájékozódnak pl. a barátok tevékenységéről, vagy maguk is frissítik állapotukat (pl. videót raknak fel), mások naponta többször, vagy folyamatosan (pl. chatelés, applikációk használata) online vannak, ők azok, akik figyelmüket megosztva foglalkoznak munkával és egyéb nem a munkához kötődő feladatokkal.

\section{Médiafogyasztás}

Többen szinte folyamatosan zenét hallgatnak munka közben a monotonitás, vagy a külső zajok zavaró hatásának elfedésére. Vannak olyanok, akik egész nap ezt teszik és sokan videós portálokat (leggyakrabban YouTube) használnak erre a célra - ezzel nagymértékű adatforgalmat generálva115 - de olyan is akad, aki CD-lemezt hallgat és csak a munka kommunikatív részében függesztik fel ezt a tevékenységet. Sokak számára a képernyőn végzett feladat mellett „szükség van arra, hogy egy kis zaj legyen”, de akadnak olyanok is, akiket zavar a zene, mert eltereli a figyelmet a feladatról. Többen beszámoltak arról, hogy a munkahelyükön a zene-, és a video-lejátszók is le vannak tiltva a számítógépeken, ilyenkor a zenét vagy hagyományos rádió, vagy egyénileg mp3lejátszó segítségével hallgatják.

A fókuszcsoportokon kiderült, hogy a számítógép előtt dolgozók szoktak alkalomadtán játszani is. Tapasztalataink alapján a játék nem idegen tevékenység, de kiugróan sokat játszó munkatársak nem sokan vannak.

Az infokommunikációs eszközökhöz kötődő párhuzamos tevékenységekkel kapcsolatban elmondható, hogy az szinte kivétel nélkül mindenkinél jelen van. Gyakori, hogy több ablak van megnyitva, átlagosan 5-6 alkalmazást használnak egyszerre, amelyek zömmel a munkához kötődnek. A megosztott figyelem egyik határa az, amikor

\footnotetext{
115 Egy multinacionális vállalat esetében sikerült a cég informatikusaival is beszélni, akik szerint a cégnél a hálózatos összforgalom 40 százaléka streaming média (pl. YouTube), amely zömmel nem vállalati stream. Ráadásul a maradék 60 százalékban benne lehet még a játék, e-mail, hírek, torrentezés stb. is. Nehéz megbecsülni az arányokat, azonban a számok azt sejtetik, hogy az internetes forgalom zömét nem a munkafeladatok generálják.
} 
már összefolynak az ablakok, amikor már nem lehet megkülönböztetni, hogy melyik micsoda.

„Amikor már nem tudom követni. Mikor már mondjuk, 10 ablak van nyitva a tálcán. De lehet, hogy ennél több is meg van nyitva, ha mondjuk kerestem valamit, de ha már nem kellenek az adott oldalak, akkor gyorsan becsukom őket. Ha van nyitva olyan ablak, amiről már nem tudom, hogy miért kellett, akkor azt is gyorsan becsukom." (29 éves, budapesti diplomás férfi)

Az ember mellett a technológia is besokallhat, „néha a gép fogja magát és kilép mindenből" - mondja az egyik résztvevő. Általában egyetértenek abban, hogy a multitasking hatékonyabbá teheti a munkát, azonban a túl sok ablak már erős tehertétel és jelentősen gátolja a munkavégzést. Praktikus és a tapasztalatok szerint gyorsítja a munkát, ha azok a programok mind nyitva vannak, amelyek kellenek az adott munkafolyamathoz, mindössze egy esetben találkoztunk olyannal, aki egyetlen alkalmazást használ egyszerre. A munkához kapcsolódó alkalmazások mellett általában folyamatosan jelen vannak a magáncélú alkalmazások-oldalak is, amelyek két ellentétes hatást válthatnak ki: pihentetnek és egyben el is vonhatják a figyelmet.

„Én nem tudom, hogy rontja-e a teljesítményt, de nálam van olyan, hogy dolgozom három ablakban, de meg vannak nyitva más ablakok is, mert ha kapok, mondjuk egy telefonhívást, akkor azok is kellenek. És akkor az engem kicsit felfrissít, hogy nem csak abban a három ablakban ugrálok egész nap." (26 éves, diplomás nő)

„Nagyobb a vonzás, ha nyitva vannak az ablakok, például a levelezés. Akkor állandóan odakattint az ember, hogy írt-e valaki. Ez tudja gátolni az embert. Nálam a Facebook-kal van így." (25 éves, érettségizett férfi)

A nemzetközi hátterű cégek munkatársai egyetértenek abban, hogy a multitasking alkalmazását szükségszerűen meg kell tanulni. A figyelemmegosztás általános vélekedés szerint egész életvitelüket meghatározza. Az alapos munka és a multitasking követelménye egyszerre terheli a munkavállalókat. „Aki csak egy dologra képes figyelni, az nem állja meg itt a helyét." Az új munkatársak betanításánál mindez látványosan 
megjelenik - az újaknak sokszor követhetetlen a munkamenet, ráadásul a nyelvezetet is érteni kell.

A párhuzamos feladatok hatékony menedzselésében többek szerint a fontossági sorrend alkalmazása célravezető. Prioritásokat határoznak meg, elsőbbséget élvez a határidős munka, „minden más kirekesztve”. Lényeges a work-life balance, az egyensúly megtartása a magánélet és a munka között, odafigyelve a túlórákra. A munka közbeni zenehallgatás sem mindig pihentet: többen beszámoltak róla, hogy koncentrációigényes feladat esetén, ha zenét hallgatnak, gyakrabban hibáznak. Adminisztrációs, monoton feladat esetén viszont épp az ellenkezőjéről számolnak be, ott a „muszáj, hogy hallgassak valamit" érvényesül.

Általánosságban elmondható, hogy döntően irodai programokat (Outlook, Word, Excel, PowerPoint, SAP-t) használnak. Vannak azért különleges esetek, amikor a sokkal koncentráltabban csak egyetlen dologgal foglalkoznak, ilyen lehet a riportkészítés, illetve ha határidős feladat van. A megszokott, folyamatosan futó alkalmazások fontos elemei a hatékony munkának.

A magáncélú internethasználatról a munkavállalók döntően azt gondolják, hogy javítja a teljesítményt. Van, aki célzatosan igyekszik egyensúlyt teremteni a munka és a privát ügyek között. Ötperces pihenőket iktat be, amikor privát beszélgetéseit bonyolítja, ez megnyugtatja. Más munka közben nem használja a Facebook-ot, Skype-ot, MSN-t, azaz nincs online, azonban napjában általában háromszor, reggel, ebéd után és hazaindulás előtt megnézi, hogy érkezett-e üzenete. A fókuszcsoportokon nem találkoztunk olyannal, aki bevallotta volna a folyamatos bekapcsoltságot, más kollégákról azonban elmondtak ilyeneket. A magáncélú internethasználat az általános vélemények alapján nem olyan gyakori, mert annyi munka van, hogy nem tudnának erre időt szakítani.

A 2012-ben készült online kérdőíves kutatás eredményeiből láthattuk, hogy a zene mint a különböző tevékenységek mellé leggyakrabban társuló médium munkatevékenységek mellett inkább van jelen, mint tanulás során. A munka mellé a kérdezettek kétötöde (41\%) számára gyakran társul zene, míg a tanulás esetén ez az arány csupán 15 százalék. Alaposabban megvizsgálva a zenehallgatás körülményeit megfigyelhetjük, hogy a válaszadók nagyjából negyede (27\%) számára zavaró a zene az odafigyelést igénylő tevékenységek (pl. munka, tanulás) során, ugyanakkor közel ugyanennyien (22\%) számoltak be a zene segítő hatásáról is. 
45. ábra: Ön számára az odafigyelést igénylő tevékenységek (pl. munka, tanulás) esetén a zene inkább zavarja, vagy inkább segíti a koncentrációt? (N=1000; Forrás: Kutatópont, 2012)

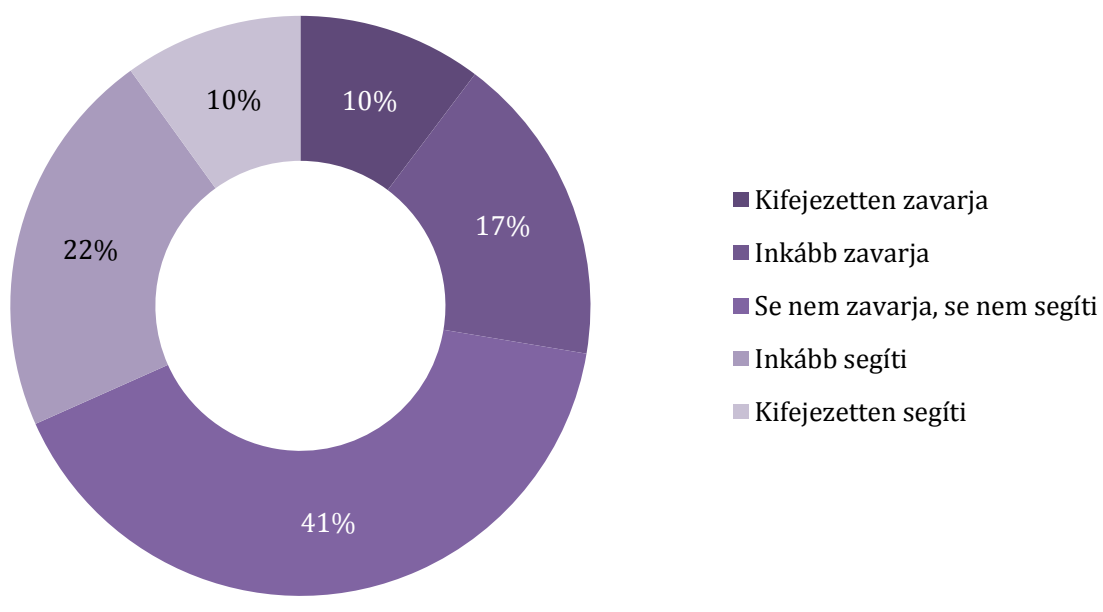

A kérdést megkíséreltük kissé jobban árnyalni azzal, hogy indirekt módon próbáltunk a zene lehetséges zavaró hatására rákérdezni. A kérdezetteket arra kértük, hogy válaszoljanak arra, hogy milyen gyakran szakítják meg a zene miatt az éppen végzett feladatukat. Azt találtuk, hogy minden negyedik (25\%) megkérdezett egyáltalán nem tud beszámolni ilyen esetről, a többség (59\%) csak ritkán, míg a kérdezettek hatoda (16\%) gyakran tapasztal ilyesmit.

46. ábra: Milyen gyakran szakítja meg a zene miatt az éppen végzett feladatát (pl. együtt dúdolja a dallamot a zenével, vagy az éppen hallgatott zeneszám hatására rákeres valamire az interneten)? (N=1000; Forrás: Kutatópont, 2012)

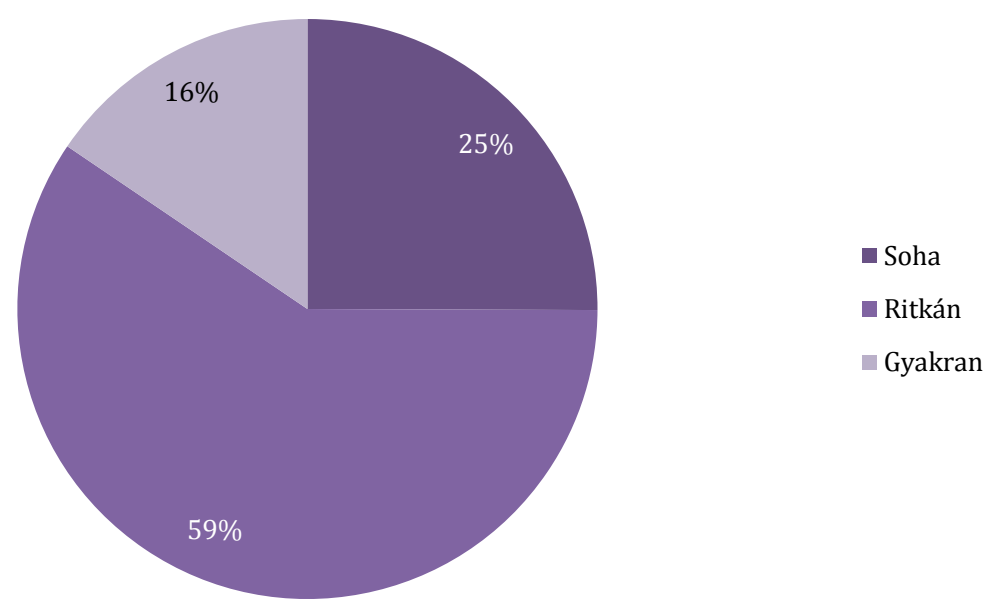




\section{6. ÖSSZEFOGLALÁS - TOVÁBBI IRÁNYOK}

\subsection{TAPASZTALATOK ÖSSZEGZÉSE}

Munkámban a kommunikáció- és médiafogyasztás elmúlt időszakban végbement változásaira koncentráltam, igyekeztem felhívni a figyelmet az egyidejű többcsatornás kommunikáció és médiafogyasztás jelentőségére. A média- és kommunikációs tevékenységek összemosódását különböző, a témával foglalkozó munkák által felrajzolt - egymással szorosabb-lazább kapcsolatban lévő - narratívák szerint vizsgáltam az információs társadalom rendszerszintű hatásaitól a környezeti hatásokon át az egyéni szinten jelenlévő kognitív szempontokig.

A különböző multitaskinggal foglalkozó főként elméleti munkák alapján megfogalmaztam azon szempontokat, amelyek alapján a párhuzamos tevékenységek jellemezhetők. Ezek a következők: (1) a tevékenységek szándékolt - nem szándékolt volta; (2) az adott tevékenység tudott volta (a kognitív rendszer használata); (3) az (inter)aktivitás jelenléte, vagy hiánya; (4) valamint a multitasking folyamatban lévő tevékenységek elhelyezkedése a tevékenységhierarchiában. Ehhez kapcsolódóan összefoglaltam azokat a specifikus szempontokat, amelyek a párhuzamos médiafogyasztással és az infokommunikációs eszközökhöz kötődő parallel digitális kommunikációval foglalkozó kutatásnak szükséges figyelembe vennie, úgy mint a tevékenység célját; a multitaskingba bekapcsolódó média és kommunikációs tevékenységek számát; valamint a források számát (konvergenciát).

A média és kommunikációs multitasking legfontosabb narratívája - dolgozatom vezérmotívuma - az információs társadalomban szocializálódott fiatal generációk az idősebbektől gyökeresen eltérő szokásai szerinti értelmezés. A fiatalok infokommunikációs eszközhasználata és médiafogyasztása jelentősen különbözik az idősebbekétől: az új infokommunikációs eszközök megjelenése mellett ebben minden bizonnyal szerepe van a korábban nem tapasztalt tartalombőségnek is. A kutatásom egyértelműen bizonyította, hogy a fiatalok számára az internet az elsőszámú médium, és ez mind az információs mind a szórakoztató tartalmak esetében igaz. Nem kétséges, hogy az internethasználat terjedése elsősorban a hagyományos médiumokra való 
odafigyelés kárára történik. A televízió háttérbe szorulása jól érzékelhető mind a nemzetközi mind az magyarországi empirikus kutatásokban, azzal együtt, hogy az egész társadalomra vonatkoztatva még mindig őrzi kiemelt szerepét. A fiatalok körében készült fókuszcsoportokból leszűrhető tapasztalatok teljes mértékben alátámasztják a kvantitatív kutatásokban megfigyelhető tendenciákat: a fiatal korosztályokban a televízió fontosságát már megelőzi az internet. A televízió térvesztése mellett a többi hagyományos médium - rádió, nyomtatott kiadványok - is helyét keresi a fiatalok életében. Ugyanakkor egyértelműen bebizonyosodott a zenei tartalmak fontossága. Az is kiderült, hogy a zenehallgatás - ami amúgy is jellemzően a számítógépen, illetve újabban okostelefonon keresztül történik - remekül kiegészíti az egyéb online tevékenységeket: miközben a felhasználók az interneten böngésznek, játszanak, vagy éppen személyes kommunikációt folytatnak (pl. chat), a háttérben folyamatosan szól valamilyen zene. A kutatás kvantitatív és kvalitatív tapasztalatai is azt mutatják, hogy a zene esetében van leginkább jelen a párhuzamosság.

A kutatómunkám eredményeként kijelenthető, hogy a fiatalok sokkal magabiztosabban kezelik az infokommunikációs eszközöket, de emellett a tartalom szelektálásában is sokkal nagyobb tudatosságot mutatnak, mint ahogy azt sokan gondolnák. Tudják, hogy mit és miért fogyasztanak, ráadásul nagyfokú racionalitást mutat, hogy az egymás mellett jól „megférő” tevékenységeket gyakran párhuzamosan végzik, így kihasználva a rendelkezésre álló szűkös szabadidőt.

A média és kommunikációs multitaskingról kutatásaim alapján elmondható, hogy mindennapos tevékenység, az emberek nagy része kisebb-nagyobb gyakorisággal folyamatosan él vele. Gyakran adódnak olyan helyzetek, amikor médiahasználat közben megosztjuk figyelmünket és gyakoriak az olyan kommunikációs tevékenységek, amelyek mellett más (gyakran média jellegű) feladatokat is végzünk.

A párhuzamosság egyértelműen megjelenik a fiatalok körében, különösen online (különböző számítógépes alkalmazások egyidejű futtatása), de esetenként az online hagyományos média kevert formájában is (pl. televízió nézés és internet használat egyidejűsége). A nemzetközi tapasztalatokhoz hasonlóan a hazai tapasztalatok is azt igazolták, hogy minél fiatalabbakat vizsgálunk, annál inkább jellemző a multitasking, még ha az egyes korosztályokon belül vannak is egyéni különbségek, pl. a pszichológiai 
jellemzőknek, szokásoknak vagy éppen a háztartás méretének, anyagi helyzetének köszönhetően.

Dolgozatomban fontos kérdésként kezeltem az egyidejű médiafogyasztás és kommunikáció szocializációs kapcsolódásait, más szóval az egyes generációk multitasking karakterét. A korábban talált médiafogyasztással kapcsolatos generációs törésponttal a multitasking vizsgálata során megmutatkozó töréspont nem feltétlenül esik egybe, az adatok nagyjából egy évtizednyi különbséget mutatnak. Az egyes generációkkal kapcsolatos, különböző megközelítésekre építkező vizsgálataim alapján megállapítható, hogy a médiafogyasztás jellemzői alapján egyértelmű generációs határokat nem lehet meghatározni.

Az empirikus tapasztalataim alapján megállapítható, hogy a kognitív szempontú megközelítések visszatérő motívuma a figyelemmegosztásból származó negatívumok többnyire nem igazolhatók, ennek okai a multitaskingba belépő tevékenység céljainak és jellegének különbségeiből fakadnak. Az empirikus tapasztalatok alapján megfigyelhető, hogy a különböző tevékenységekhez kapcsolódóan nem azonos intenzitású párhuzamosság jellemző. A hipotézisek megerősítését láthatjuk abban, hogy a rekreációs tevékenységekben, valamint a (főleg online) kommunikációban lényegesen jelentősebb szerepet kap a multitasking, mint az erőforrás-bővítő tevékenységekben. A szimultán tevékenységeket gyakran folytatók is bizonyos, koncentrációt igénylő szituációkban (pl. egy elgondolkodtató feladat megoldásakor) felhagynak a figyelmet jobban igénybevevő párhuzamos tevékenységekkel, ilyenkor megpróbálnak csak egy dologra figyelni. Meglátásom szerint tehát nem véletlen, hogy a multitasking elsősorban a személyes kommunikáció és a szórakozás különböző formáihoz kötődik, így pl. online csevegéshez, zenehallgatáshoz, tévézéshez, stb. 


\subsection{HIPOTÉZISEK VIZSGÁLATÁNAK EREDMÉNYEI}

Dolgozatomban az egyidejű többcsatornás kommunikáció és médiafogyasztáshoz kapcsolódó kutatási kérdéseimhez két fő és két-két alárendelt, összesen tehát hat hipotézist fogalmaztam meg, amelyeket többé-kevésbé sikerült igazolni.

A kutatásom egyik főbb kérdéséhez - miszerint, hogy a fiatalok médiafogyasztásában tapasztalható jellegzetességek korspecifikusak, vagy generációs hatás érvényesül kapcsolódó hipotéziseket csak részben tekinthetjük igazoltnak, ugyanis az alternatív magyarázatok sem vethetők el. Megállapítható, hogy a médiafogyasztás és kommunikációs szokások megfigyelt jellegzetességeivel kapcsolatban igazolhatók a generációs hatások, azonban a generációk pontos határainak (születési évszámoknak) meghatározása nem lehetséges, illetve a generációs jelleg alig rendelkezik magasabb magyarázóerővel, mint az életkori, illetve az idő jelleg.

A kutatásom másik fő kérdéséhez - miszerint van-e különbség a párhuzamos használatban a tevékenységek jellege szerint - kapcsolódó hipotézisek igazoltnak tekinthetők. A kvantitatív vizsgálat szerint szignifikáns különbség van a rekreációs, illetve az erőforrás-bővítő tevékenységekhez kapcsolódó multitasking mértékében, amelyet a fókuszcsoportos vizsgálatok eredményei is megerősítenek.

26. táblázat: Hipotézisek vizsgálatának eredménye

\begin{tabular}{|c|c|c|}
\hline Hipotézisek & $\begin{array}{l}\text { Hipotézisvizsgálat } \\
\text { módszere }\end{array}$ & $\begin{array}{l}\text { Hipotézisvizsgálat } \\
\text { eredménye }\end{array}$ \\
\hline $\begin{array}{l}\text { H1: A médiafogyasztásban az életkori sajátosságok mellett } \\
\text { generációs hatások is érvényesülnek, ami azt jelenti, hogy léteznek } \\
\text { olyan, a születési évek alapján meghatározható csoportok } \\
\text { (generációk), amelyek médiafogyasztási jellegzetességeiket az évek } \\
\text { múlásával is megőrzik. }\end{array}$ & $\begin{array}{l}\text { kvantitatív, lineáris } \\
\text { regresszió és } \\
\text { varianciaanalízis }\end{array}$ & részben igazolható \\
\hline $\begin{array}{l}\text { H1.1: A médiafogyasztás mennyisége és a párhuzamos fogyasztás } \\
\text { mértéke szerint is jelen vannak a generációs töréspontok. }\end{array}$ & $\begin{array}{l}\text { kvantitatív, lineáris } \\
\text { regresszió és } \\
\text { varianciaanalízis }\end{array}$ & részben igazolható \\
\hline $\begin{array}{l}\text { H1.2: A párhuzamos fogyasztás generációs „határai” nem esnek } \\
\text { egybe a fogyasztás mennyiségének generációs töréspontjaival. }\end{array}$ & $\begin{array}{l}\text { kvantitatív, lineáris } \\
\text { regresszió és } \\
\text { varianciaanalízis }\end{array}$ & részben igazolható \\
\hline $\begin{array}{l}\text { H2: A párhuzamosság mértékének fontos magyarázója a } \\
\text { tevékenység jellege: a különböző típusú tevékenységekhez nem } \\
\text { azonos intenzitású multitasking társul. }\end{array}$ & $\begin{array}{l}\text { kvantitatív, } \\
\text { faktoranalízis }\end{array}$ & igazolt \\
\hline $\begin{array}{l}\text { H2.1: A rekreációs (média és kommunikációs) tevékenységekben, } \\
\text { jelentősebb szerepet kap a multitasking, mint az erőforrás- } \\
\text { bővítésben (munka, tanulás). }\end{array}$ & $\begin{array}{c}\text { kvantitatív } \\
\text { (faktoranalízis) és } \\
\text { kvalitatív } \\
\text { (fókuszcsoportok) }\end{array}$ & igazolt \\
\hline $\begin{array}{l}\text { H2.2: A különböző tevékenységek során megfigyelhető multitasking } \\
\text { tevékenységek a legtöbbször nem spontán alakulnak ki, hanem } \\
\text { tervezettek, tudatosak, az egyén stratégiájától függnek. }\end{array}$ & $\begin{array}{l}\text { kvalitatív, } \\
\text { fókuszcsoportos } \\
\text { eredmények }\end{array}$ & igazolt \\
\hline
\end{tabular}




\subsection{TOVÁBBI IRÁNYOK}

A multitasking ma már jól mérhető és mindennapjainkban tapasztalható jelenség, ami a mobiltechnológia erősödésével, az okostelefonok és a tabletek terjedésével várhatóan újabb lendületet kap.

A kognitív folyamatokat kutatók számára továbbra is megválaszolatlan, hogy a multitaskingra alkalmas multimédia környezet hogyan hat az egyénekre, irányítja-e az embert a technológia, vagy egyszerűen az egyén keresi a lehetőségeket a multitaskingra. A technopesszimista sikerkönyv (Alone Together) írója Sherry Turkle és Steven Johnson a Future Perfect írója, akit Turkle provokatívan utópikus gondolkodásúnak tart beszélgettek a technológia szerepéről, előnyeiről és veszélyeiről. Beszélgetésük legérdekesebb része egyfajta metaforikus szintézis a pesszimista és az utópikus nézőpont között. Johnson szerint az internet akár a város hangos, zavaros és nyomasztó, a fizikai közelség ellenére könnyen izolálhatja az embereket, azonban sokan mégis a várost választják lakhelyüknek pont az ingergazdag környezet és a lehetséges kapcsolódások miatt. Turkle szerit úgy, ahogy a művészek a városi környezetben is megtalálták a magányt, úgy a technológiai környezetben is meg kell azt találnunk és meg kell becsülnünk.

A multimédia - mint állítja Turkle (2011) és a hasonlóan gondolkodó kutatók - alkalmas arra, hogy kitöltse azokat a töredékidőket (pl. várakozás), amelyek két tevékenység között találhatók, de be is szivároghat más (értékes) tevékenységekbe (pl. családi ebéd közben a közösségi oldal látogatása), amely magukat a tevékenységeket is befolyásolhatja. A megváltozó médiafogyasztási és kommunikációs szokások és különösképpen a multitasking vizsgálatának izgalmas területe a társas kapcsolatok világa. Az olyan erős hatású munkák, mint Putnam (1995) a csökkenő társadalmi tőkéről szóló tanulmánya, vagy éppen Turkle (2011) könyve az infokommunikációs eszközök használatához kapcsolódó elmagányosodásról elgondolkodtatóak és arra utalnak, hogy az infokommunikációs vívmányokhoz kapcsolódó megannyi pozitívum mellett lehetnek kifejezetten negatív hatások is.

A társadalomtudományos megközelítések az infokommunikációs eszközök hatásainak vizsgálatát korábban is leginkább a szabadidős terek társas vonatkozásaira korlátozták, pontosabban szembeállították a társas tevékenységeket az infokommunikációs 
eszközhöz kötődő tevékenységekkel úgy mint számítógép- és internethasználat. Az infokommunikációs infrastruktúra társadalom-átalakító hatásáról Bell már 1976-ban beszél, de kétségtelenül Putnam munkája emelte központi problémává a technológiai fejlődés hatásainak kérdéseit a társas viszonyokra vonatkozóan, hogy aztán Kraut és munkatársai (1998; 2004), illetve Wellman és Guila (1999), vagy Nie és munkatársai (2002, 2003), illetve a hazai szakirodalomból Molnár (2004), Lengyel és Lőrincz (2006), vagy legújabban Csüllög (2012) próbálják megválaszolni azt az alapvető kérdést, hogy a technológia elválaszt-e egymástól, vagy éppen összeköt bennünket. Az újabb empirikus munkák, amennyiben azok a számítógép- és internethasználatra korlátozódnak, megállapítják, hogy az infokommunikációs eszközökkel töltött idő nem a társas szabadidő, hanem más szabadidős tevékenységek - inkább a hagyományos médiahasználat - rovására növekszik. (Csüllög, 2012) Többnyire ezek a megközelítések is foglalkoznak a tevékenységek jellegének megkülönböztetésével, azonban a fókuszt nem a párhuzamosság jelenti, ilyenformán nem vizsgálják a társas tevékenységekbe betüremkedő, a figyelmet befolyásoló infokommunikációs eszközökhöz kapcsolódó aspektusokat. További vizsgálatra érdemesek tehát a társas multitasking hatásai az egyénekre, vagy az olyan közösségekre, mint a család, vagy egy-egy iskolai osztály, munkahelyi csoport.

Továbbá nem szabad elfelejtenünk azt a jelentékeny számú és fiatalokból is álló csoportot, amely nem él a multitaskinggal, médiafogyasztását és kommunikációs tevékenységét is az egycsatornás mód jellemzi. Milyen módon fogyasztanak médiát, hogyan alakulnak társas kapcsolataik egy multitaskingra hangolt világban?

Bizonyítottnak tekinthető, hogy a párhuzamos fogyasztás terjedése alapjaiban változtatja meg a médiahasználati szokásokat, de egyelőre megválaszolatlan a kérdés, hogy pontosan milyen mélységűek ezek a változások. A kutatás eredményei által kijelölt további irány lehet a kognitív szempontokat is jobban involváló műszeres mérés.

Izgalmas kihívás lehet annak a kérdésnek a tesztelése, hogy a felhasználói tapasztalatok (önbevallás) és a laboratóriumi kísérleti eredmények között fennáll-e a korreláció. Egy műszeres vizsgálati módszer alkalmas lehet arra, hogy azonosíthatóvá váljanak azok a kommunikációs és médiafogyasztási tevékenységek, amelyek károsak - függetlenek hasznosak a teljesítmény (feladatvégzés; megértés; fogyasztás) szempontjából. Az 
INTERFACE 116 integrált rendszer segítségével például időben szinkronizált módon rögzíthetők a következő adatok: képernyőtartalom, egér- ill. billentyűműveletek, szívritmus-variabilitás, bőrvezetés ${ }^{117}$, mimika és gesztus kommunikáció kamera segítségével. Az összefüggő fiziológiai görbék másodperces szinten követik a pillanatnyi mentális megterhelést, ami lehetőséget adhat a multitasking egyénben lezajló folyamatának mély elemzésre, a különbségek kimutatására.

A megváltozó médiafogyasztási és kommunikációs szokások jövőbeli trendjeivel kapcsolatosan közép- és hosszútávon nehéz magabiztos becsléseket megfogalmazni az infokommunikációs fejlődéshez hozzátartozik ugyanis a megjósolhatatlanság, amely azt jelenti, hogy jelenlegi állapotokból nagyon nehéz következtetni a jövőbeli trendekre ${ }^{118}$. A nemzetközi tapasztalatok azt mutatják - igazolandó a Rogers féle gondolatokat - hogy az infokommunikációs eszközök terjedésének üteme lassul, sőt a fejlett információs társadalmakban sok esetben stagnálást is tapasztalhatunk. Az olyan alapvető hozzáférésre és használatra építő penetrációs mutatók növekedéséhez, mint a számítógép- és az internethasználat, egyre kevésbé meggyőzhető (deprivált) csoportok bevonódását szükséges feltételeznünk (alacsony iskolai végzettségűek, idősek, rossz infrastruktúrájú településen, rossz anyagi körülmények között élők, stb).

Ha egy kicsit távolabbra próbálunk nézni és évtizedes intervallumban gondolkodunk, a mai tudásunk szerint alapvetően két forgatókönyvet vázolhatunk fel a „behálózott társadalom” jövőképét, amely a digitális nemzedékek forradalmával számol, ami erőteljesen hat a társadalom többi csoportjára is. Egy évtized múlva az Y generációba tartozók is középkorúvá és a Z generációba tartozók is keresővé, családfenntartóvá válnak. Ezek a korosztályok (ma nagyjából a 30-35 év alattiak) szinte kivétel nélkül internet-, mobileszköz-, stb. használók Magyarországin is. Ahogy arra többször is utaltam a legfiatalabb korosztályok esetében gyakorlatilag nincs különbség a magyar és a fejlettebb információs társadalmakban tapasztalható jelenségek között: hasonló a

\footnotetext{
${ }^{116} \mathrm{Az}$ INTERFACE rendszer használatát Izsó Lajos mutatja be Developing Evaluation Methodologies for Human-computer Interaction című könyvében.

${ }^{117}$ A bőrellenállás (galvanic skin response, GSR) szintje így jó indikátora a relaxáltság fokának, azonban azt, hogy a nem nyugodt, izgalmi állapotokban milyen érzelmek vannak jelen a személyben nem tudjuk: magas GSR-rel jár a kitörő boldogság és a zavart, idegesség állapota is.

118 Jeles példája ennek az SMS, amelynek eredetileg kiegészítő funkcióként szolgált, mondván - ki akarna üzenetet írni, ha beszélgetni is lehet, azóta tudjuk, hogy sokan akarnak így tenni nap mint nap. Az SMS népszerüségét mutatják a statisztikák, az SMS-író versenyek, a gyorsabb, kényelmesebb SMS-ezésre kialakított készülékek, stb. Továbbá megemlíthetnénk az SMS párját az MMS-t, amitől a mobilipar az SMS sikere alapján nagyon sokat várt, de nagyon keveset kapott. A levonható tanulság egyszerú: óvatosan kell bánnunk a jövőre vonatkozó elképzelések beválásával kapcsolatban.
} 
médiafogyasztásuk, hasonló az ízlésük, felhasználói tudásuk, stb. Tíz év múlva nem csupán a társadalom java részét fogják alkotni, de a kulcspozíciókba: vállalatok menedzsmentjébe, az állam- és közigazgatás vezető pozícióiba is ők fognak kerülni, amely óriási lökést ad az infokommunikációs fejlődésnek és óriási kényszert jelent majd a felzárkózásra.

A másik jövőkép az előzőnél sokkal lassabb változással számol. A „lassú erjedés” szcenáriója közelebb áll a Rogers féle modellhez, amely folyamatosan csökkenő ütemű bővülést feltételez. Ez a jövőkép számol azokkal a lehetőségekkel, hogy a nyugdíjba vonuló idősek, akik eddig a munkahelyükön használták az infokommunikációs eszközöket, kialakult szokásaikat megváltoztatják nyugdíjas éveikre, kiesnek a használók sorából, azonban kalkulál az ifjakkal is, akik szépen lassan megváltoztatják a társadalmat. Ugyanakkor ez a változtatás nem forradalomszerű, jelen van ugyan a fordított szocializáció, de nem érvényesül teljes körűen.

Léteznek más elképzelések is a következő évtizedre vonatkozóan, továbbá sokszorozható a fenti két szcenárió is pl. a konfliktus dimenzió beemelésével már négy kimenettel számolhatunk, a fentieken kívül „a békés egymás mellett élés” és a „szétszakadt társadalom” képével.

A penetráció növekedésével együtt az online világ jelentőségének további növekedésével is számolhatunk, hiszen a reklámok által elsődlegesen megcélzott, fizetőképesnek tartott közönség egyre több időt tölt a világhálón, és egyre kevesebb figyelmet fordít a hagyományos elektronikus médiumokra. Az eltöltött idővel párhuzamosan növekszik az internet fontosságának megítélése, a különböző kutatások adatai szerint az internetezők számára ma már az internet jelenti az elsődleges információ- és szórakozási forrást. Bár egyértelműnek látszik az internet sikere a hagyományos média hátrányára, nem szabad megfeledkezni a részletezett média multitasking jelenségéről, amely új kihívásokat teremt a hirdetők, médiatulajdonosok és mellékesen a médiakutatók számára is.

Összefoglalóan szólva a média és kommunikációs multitasking várható jövőjével kapcsolatban azt lehet mondani, hogy egyértelműen tovább fog terjedni, amit legalább három dolog ösztönöz: (1) az új generációk belépése; (2) a mobil eszközök terjedése; (3) a hirdetők, médiatulajdonosok, tartalom- és eszközgyártók stratégiái. A hirdetők és médiatulajdonosok ugyanis várhatóan úgy próbálnak megbirkózni a multitasking 
következményeivel, hogy még inkább ösztönzik a tevékenységet, még több linkelt tartalmat kínálva a médiafogyasztóknak, amelyek tovább ösztönzik elsősorban a mobileszközök használatát. Hasonlóan a hirdetési iparban tevékenykedőkhöz a többi vonatkozó iparág is egyre kifinomultabb a multitaskingra egyre alkalmasabb szolgáltatással jelenik meg, ahogy a Microsoft a legújabb Windows, napokban megjelent hirdetésében is fogalmaz:

„A Windows 8 megváltoztatja a személyi számítógép használatának módját, de továbbra is nyújtja mindazokat a szolgáltatásokat, amelyeket elvársz egy számítógéptől. Dokkold egymás mellé a két alkalmazást, és több feladatot is elvégezhetsz egy időben! Böngéssz az érintéssel vezérelhető interneten az Internet Explorer 10-zel, miközben az egyik kedvenc programodat használod, vagy nézz meg egy videót, mialatt elvégzed a feladataidat! A Windows 8-cal simán elintézhetsz két dolgot is egyszerre!” 


\section{FELHASZNÁLT IRODALOM}

\subsection{TANULMÁNYOK, MONOGRÁFIÁK}

Abram, S. - Luther, J. (2004): Born with the Chip; Library Journal, 129(8), 24-37.

Ahlers, D. (2006): News Consumption and the New Electronic Media. The Harvard International Journal of Press/Politics, 11(1), 29-52.

DOI: http://dx.doi.org/10.1177/1081180X05284317

Alperstein, N. M. (2005): Living in an age of distraction: Multitasking and simultaneous media use and the implications for advertisers, Social Science Research Network (SSRN): http://ssrn.com/abstract=1473864

Anderson, J. Q. - Rainie L. (2012): Millennials will benefit and suffer due to their hyperconnected lives, Pew Research Center's Internet \& American Life Project, Washington, D.C.

Anderson, D. R. - Hanson, K. G. (2009): Peer Consonance: Children, Media and Methodology. American Behavioral Scientist, 52(8), 1204-1219.

Bannister, F. - Remenyi, D. (2009): Multitasking: the Uncertain Impact of Technology on Knowledge Workers and Managers. The Electronic Journal Information Systems Evaluation, 12(1), 1-12.

Barabási, A. L. (2008): Behálózva - A hálózatok új tudománya (Helikon, 2008)

Baron, N. S. (2006): Adjusting the Volume: Technology and Multitasking in Discourse Control. Manuscript

Bawden, D. - Robinson, L. (2009): The dark side of information: overload, anxiety and other paradoxes and pathologies. Journal of Information Science, 35(3), 180-191.

DOI: $\underline{\text { http://dx.doi.org/10.1177/0165551508095781 }}$

Becker, M. W. - Alzahabi, R. - Hopwood, C. J. (2013): Media Multitasking is Associated with Symptoms of Depression and Social Anxiety. Cyberpsychology, Behavior, and Social Networking,16(2), 132-135.

DOI: http://dx.doi.org/10.1089/cyber.2012.0291

Beckers, J. - Schmidt, H. (2003): Computer experience and computer anxiety. Computers in Human Behavior, 19, 785-797.

DOI: http://dx.doi.org/10.1016/S0747-5632(03)00005-0 
Beckers, J. - Schmidt, H. - Wechters, J. (2008): Computer Anxiety in Daily Life: Old History? in: Loos, E. - Mante-Meijer, E. - Haddon, L. /ed./: The Social Dynamics of Information and Communication Technology. Ashgate, Aldershot, 13-24.

Bell, D. (1973): The Coming of Post-Industrial Society New York, Basic Books

Bessenyei, I. (2007): Tanulás és tanítás az információs társadalomban (Network for Teaching Information Society, 2007)

Bianchi S. M. (2011): Family Change and Time Allocation in American Families. The ANNALS of the American Academy of Political and Social Science November 2011, 21-44.

DOI: http://dx.doi.org/10.1177/0002716211413731

Bodoky, T. (2009): Internetes hírfogyasztás Magyarországon. Jel-Kép, 2009/1, 61-83.

Bodoky, T. (2007): „Nincs tévém, nem olvasok papírújságot”. Médiakutató 2007, nyár: http://www.mediakutato.hu/cikk/2007 02 nyar/06 nincs tevem/

Bognár, É. - Rét, Zs. (2005): A digitális egyenlőtlenségek kulturális vonatkozásai (in: Dessewffy Tibor - Fábián Zoltán - Z. Karvalics László /szerk./ Internet.hu - A magyar társadalom digitális gyorsfényképe 2., 124-152.)

Brooks-Gunn, J. - Hirschhorn, D. E. (2008): Introducing the Issue. The Future of Children, 18(1), 3-10.

DOI: http://dx.doi.org/10.1353/foc. 0.0008

Broos, A. - Roe, K. (2006): The digital divide in the playstation generation: Self-efficacy, locus of control and ICT adoption among adolescents. Poetics, 34, 306-317.

Bujdosóné, D. E. (2012): Neumann kontra Gutenberg-galaxis? - Különös tekintettel a generációs olvasási szokásokra (Networkshop konferencia - 2012 előadás)

Burak, L. (2012): Multitasking in the University Classroom. International Journal for the Scholarship of Teaching and Learning, 6(2)

Carr, N. (2010): The Shallows: What the Internet Is Doing to Our Brains (2010, W. W. Norton)

Carrier, L. M. - Cheever, N. A. - Rosen, L. D. - Benitez, S. - Chang, J. (2009): Multitasking across generations: Multitasking choices and difficulty ratings in three generations of Americans. Computers in Human Behavior, 25, 483-489.

DOI: http://dx.doi.org/10.1016/j.chb.2008.10.012

Castells, M. (2005): Az információ kora: Gazdaság, társadalom és kultúra I. kötet: A hálózati társadalom kialakulása (Gondolat-Infonia, Budapest) 
Christakis, D. A. - Zimmerman, F. J. (2009): Young Children and Media: Limitations of Current Knowledge and Future Directions for Research. American Behavioral Scientist, 52(8), 1177-1185.

\section{DOI: http://dx.doi.org/10.1177/0002764209331540}

Criss, B. R. (2006): Gender differences in multitasking. Missouri Western State University, Manuscript: http://clearinghouse.missouriwestern.edu/manuscripts/815.php

Csótó, M. - Székely, L. (2009): Indicators of Internet usage: does the Internet reflect regional inequalities within Hungary? NETCOM, 23(1-2), 49-62.

Csüllög, K. (2012): Szabadidős netezés: társasan vagy magányosan? Információs Társadalom,12(2), 24-40.

Cowan, N. (2006): Working Memory Capacity. Developmental Neuropsychology, 35(5), 447-474.

DOI: http://dx.doi.org/10.1080/87565641.2010.494985

Cummings, M. L. - Clare, A. - Hart, C. (2010): The Role of Human-Automation Consensus in Multiple Unmanned Vehicle Scheduling. Human Factors: The Journal of the Human Factors and Ergonomics Society. 52(1), 17-27.

DOI: $\underline{\text { http://dx.doi.org/10.1177/0018720810368674 }}$

Diósi, P. - Székely, L. (2009): Szakmai sztenderdek az ifjúsági kutatásokhoz. Új Ifjúsági Szemle, 7(1), 19-57.

Diósi, P. - Székely, L. (2008): Az ifjúság megismerésének alapjai: az ifjúságkutatás (in.: Nagy, Á. /szerk./: Ifjúságügy. Palócvilág - Új Mandátum, Budapest. 465-489.)

Dolliver, M. (2012): Time Spent with Media: Consumer Behavior in the Age of Multitasking; eMarketer, Inc.

Duits, L. (2010): The importance of popular media in everyday girl culture. European Journal of Communication, 25(3), 243-257.

DOI: $\underline{\text { http://dx.doi.org/10.1177/0267323110373461 }}$

Estes, W. K. (1976): Handbook of Learning and Cognitive Processes. Volume 4 Attention and Memory Lawrence Erlbaum Associates Inc.

Fábián, Z. (2005): Az IKT hozzáférés és használat kölcsönhatása a társadalmi egyenlőtlenségi rendszerrel. Esettanulmány az IKT hozzáférési és használati indexek alkalmazásával (in: Dessewffy, T. - Fábián, Z. - Z. Karvalics, L. /szerk./ Internet.hu - A magyar társadalom digitális gyorsfényképe 2., 187-212.) 
Foehr, U. G. (2006): Media Multitasking Among American Youth: Prevalence, predictors and pairings. Menlo Park, CA: Kaiser Family Foundation.

Friedrich, R. - Le Merle, M. - Peterson, M. - Koster, A. (2010): The Rise of Generation C Implications for the World of 2020, Booz \& Company: http://www.booz.com/media/file/Rise Of Generation C.pdf

Futó, P. - Rab, Á. (2007): Információs társadalom fogalomtár, Budapesti Corvinus Egyetem - Információs Társadalom c. kurzushoz kapcsolódóan

Galácz, A. - Ságvári, B. (2008): Digitális döntések és másodlagos egyenlőtlenségek: a digitális megosztottság új koncepciói szerinti vizsgálat Magyarországon. Kézirat

Gálik, M. - Urbán Á. (2008): Bevezetés a médiagazdaságtanba. Aula Kiadó, Budapest

Gálik, M. (2003): Médiagazdaságtan. Aula, Budapest.

Garrett, R. K. - Danziger, J. N. (2007): IM=Interruption management? Instant messaging and disruption in the workplace. Journal of Computer-Mediated Communication, 13, 2342 .

DOI: http://dx.doi.org/10.1111/j.1083-6101.2007.00384.x

Goldfarb, A. - Prince, J. (2008): Internet adoption and usage patterns are different: Implications for the digital divide. Information Economics and Policy, 20, 2-15.

DOI: http://dx.doi.org/10.1016/j.infoecopol.2007.05.001

Goldhaber, M. H. (2004): The Mentality of Homo Interneticus: Some Ongian Postulates. First Monday 9(6). http://firstmonday.org/issues/issue9 6/goldhaber/index.html

González, V. - Mark, G. (2004): Constant, Constant, Multitasking Craziness: Managing Multiple Work Spheres. CHI, 6(1), 113-120.

Hargittai, E. (2010): Digital Na(t)ives? Variation in Internet Skills and Uses among Members of the "Net Generation" Sociological Inquiry, 80(1), 92-113.

DOI: http://dx.doi.org/10.1111/j.1475-682X.2009.00317.x

Hembrooke, H. - Gay, G. (2003): The Laptop and the Lecture: The Effects of Multitasking in Learning Environments. Journal of Computing in Higher Education, 15(1), 46-64.

DOI: http://dx.doi.org/10.1007/BF02940852

Hulme, M. (2009): Life Support: Young people's needs in a digital age, YouthNet: http://www.youthnet.org/wp-content/uploads/2011/05/Life-Support-Report.pdf

Hundley, H. L. - Shyles, L. (2010): US teenagers' perceptions and awareness of digital technology: a focus group approach. New Media \& Society, 12(3), 417-433. 
DOI: http://dx.doi.org/10.1177/1461444809342558

Izsó, L. (2001): Developing Evaluation Methodologies for Human-computer Interaction. Delft University Press.

Jackson, M. (2008): Distracted: The Erosion of Attention and the Coming Dark Age. Amherst, N.Y., and Oxford: Prometheus Books.

Jain, S. (2007): Media Multitasking in the Age of Interruption: When Teens Pay Attention to Everything All at Once. April 23.

Jenkins, H. - Purushotma, R. - Weigel, M. - Clinton, K. - Robinson, A. J. (2009): Confronting the Challenges of Participatory Culture: Media Education for the 21st Century. Building the field of digital media and learning (Massachusetts Institute of Technology, 2009)

Jukes, I. (2005): Understanding Digital Kids; The InfoSavvy Group

Kaufhold, W. T. K. (2010): Peer Consonance: Age Matters in Story Selection and Presentation Among Television News Producers. Electronic News, 4(1), 7-22.

DOI: http://dx.doi.org/10.1177/1931243110361587

Kenyon, S. (2008): Internet Use and Time Use: The importance of multitasking. Time Society, 17(2-3), 283-318.

DOI: http://dx.doi.org/10.1177/0961463X08093426

Kenyon, S. - Lyons, G. (2007): Introducing multitasking to the study of travel and ICT: Examining its extent and potential importance ransportation Research Part A, 41(2), 161-175.

DOI: http://dx.doi.org/10.1016/j.tra.2006.02.004

Kollányi, B. - Székely, L. (2006): Hátrányos helyzetű társadalmi csoportok az információs társadalomban. Információs Társadalom, 6(2), 48-67.

Koltay T. (2009): Médiaműveltség, média-írástudás, digitális írástudás. Médiakutató 2009 tél: http://mediakutato.hu/cikk/2009 04 tel/08 mediamuveltseg digitalis irastudas/01.html?q=rai

Kraut, R. - Rainie, L. - Shklovski, I. (2004): The Internet and Social Participation: Contrasting Cross-Sectional and Longitudinal Analyses. Journal of Computer-Mediated Communication, 10(1).

DOI: http://dx.doi.org/10.1111/j.1083-6101.2004.tb00226.x 
Kraut, R. - Patterson, M. - Lundmark, V. - Kiesler, S. - Mukhopadhyay, T. - Scherlis, W. (1998): Internet paradox: A social technology that reduces social involvement andpsychological well-being? American Psychologist, 53(9), 1017-1031.

DOI: http://dx.doi.org/10.1037/0003-066X.53.9.1017

Kuczi, T. (2004): Tranzakciós költségek és munkaszervezetek. Szociológiai Szemle $2004 / 4,25-46$.

Lauricella, A. R. - Barr, R. F. - Calvert, S. L. (2009): Emerging Computer Skills: Influences of Young Children's Executive Functioning Abilities and Parental Scaffolding Techniques. Journal of Children and Media, 3, 217-233.

Lengyel, Gy. (2003): Az információs technológia terjedésének társadalmi hatásairól. Kultúra és közösség, (7)4, 47-56.

Lengyel, Gy. - Lőrincz, L. (2006): Internet és szabadidő. (in: Dessewffy, T. - Fábián, Z. - Z. Karvalics, L. /szerk./: Internet.hu - A magyar társadalom digitális gyorsfényképe 3.111136.)

Mazmanian, M. - Yates, J. - Orlikowski, W. (2006): Ubiquitous email: Individual experiences and organizational consequences of BlackBerry use. Proceedings of the 65th annual meeting of the Academy of Management, Atlanta GA: August 2006.

Molnár, Sz. - Kollányi, B. - Székely, L. (2007): Social networks and the network society. (in: Pintér, R. /ed./: Information society - coursebook. Gondolat - Új Manátum, 62-79.)

Molnár, Sz. (2004): Sociability and Internet. Review of Sociology, 10(2), 67-84.

Morris, A. - Goodman, J. - Brading, H. (2007): Internet use and non-use: views of older users. Univ Access Inf Soc 6, 43-57.

DOI: $\underline{\text { http://dx.doi.org/10.1007/s10209-006-0057-5 }}$

Moshe, M. (2012): Media Time Squeezing: The Privatization of the Media Time Sphere. Television New Media, (13)1, 68-88.

DOI: http://dx.doi.org/10.1177/1527476410392805

Nagy, Á. - Székely, L. (2013): Beyond School and Family: The Basis and the Structure of the Tertiary Socialization Field and the "Youth-Affairs" as an Autonomous Area (in: Trejos-Castillo, E. /ed./: Youth: Practices, Perspectives and Challenges. Nova, 137-158)

Nagy, Á. - Trencsényi, L. (2012): Szocializációs közegek a változó társadalomban - A nevelés esélyei: család, iskola, szabadidő, média (Ifjúságszakmai Társaság Alapítvány, Budapest) 
Nagy, Á. (2008): Ifjúságügy, ifjúsági szakma, ifjúsági munka, Palócvilág-Új Mandátum, 2008, Budapest

Nagy, R. (2007): Digitális egyenlőtlenségek: mítosz vagy valóság? Információs Társadalom, 7(2), 17-30.

Nagy, R. (2005): Digitális egyenlőtlenségek: mítosz vagy valóság? Információs technológiák használatának aspektusai az ifjúság körében. Ph.D. disszertáció. Budapesti Corvinus Egyetem, Budapest

Nguyen, A. (2010): Harnessing the potential of online news: Suggestions from a study on the relationship between online news advantages and its post-adoption consequences. Journalism, 11(2), 223-241.

DOI: http://dx.doi.org/10.1177/1464884909355910

Nie, N. H. - Hillygus, D. S. - Erbring, L. (2003): Internet Use, Interpersonal Relations and Sociability: A Time Diary Study. (in: Wellman, B. - aythornwaite C. /ed./: Internet and the Everyday Life. Oxford: Blackwell. 215-243)

Nie, N. H. - Hillygus, D. S. (2002): The Impact of Internet Use on Sociability: Time-Diary Findings. IT \& Society, 1(1), 1-20.

Nyeste, G. (2003): A magyar információs társadalom időmérlege (in: Lengyel, Gy. /szerk/: Információs technológiák és digitális szakadék 67-88.)

Nyirő, N. - Urbán, Á (2010): Vége a hagyományos tévézésnek? Médiakutató 2010, ősz: http://www.mediakutato.hu/cikk/2010 03 osz/03 teve kesleltetett time shift

Ophir, E. O. - Nass, C. - Wagner, A. (2009): Cognitive control in media multitaskers. Proceedings of the National Academy of Sciences, 106(37),15583-15587.

\section{DOI: http://dx.doi.org/10.1073/pnas.0903620106}

Pilotta, J. J. - Schultz, D. E. - Drenik, G. (2003): „Simultaneous Media Usage”: A Critical Consumer Orientation to Media Planning. Journal of Consumer Behaviour. PrePublications Release.

Pintér, R. (2005): A hazai médiafogyasztás (át)alakulása az internet tükrében. (in: Dessewffy T. - Fábián, Z. - Z. Karvalics, L. /szerk./: Internet.hu - A magyar társadalom digitális gyorsfényképe 2., 153-186.)

Pintér, R. (2007): Towards getting to know information society. (in: Pintér, R. /ed./: Information society - coursebook. Gondolat - Új Manátum, 11-28.)

Pintér, R. - Székely, L. (2006): Bezzeg a mai fiatalok - a tizenéves korosztály médiafogyasztása a többségi társadalom tükrében. (in: Dessewffy, T. - Fábián, Z. - Z. Karvalics, L. /szerk./: Internet.hu - A magyar társadalom digitális gyorsfényképe 3. 137160.) 
Pool, M.M. - Koolstra, C.M. - van der Voort, T. H. A. (2003): Background media and homework performance. Journal of Communication, 53, 74-87.

DOI: http://dx.doi.org/10.1111/i.1460-2466.2003.tb03006.x

Prensky, M. (2001): Digital natives, digital immigrants. On the Horizon - MCB University Press, 9(5), 1-6.

\section{DOI: http://dx.doi.org/10.1108/10748120110424816}

Putnam, R. D. (2006 [1995]): Egyedül tekézni: Amerika csökkenő társadalmi tőkéje. (in: Lengyel, Gy. - Szántó Z. /szerk./: Gazdaságszociológia. Szöveggyűjtemény. Budapest: Aula, 207-219.)

Rab, Á. (2007): Digital culture - Digitalised culture and culture created on a digital platform (in: Pintér, R. /ed./: Information society - coursebook. Gondolat - Új Manátum, 183-201.)

Rab, Á. - Székely L. (2007): Változó ifjúság az információs társadalomban (in.: Nagy, Á. /szerk./: Ifjúságsegítés - Probléma vagy lehetőség az ifjúság. Belvedere - Palócvilág - Új Mandátum, Budapest - Szeged, 224-244.)

Reinsch, N. L. - Turner, J. W. - Tinsley, C. H. (2008): Multicommunicating: A practice whose time has come? Academy of Management Review, (33)2, 391-403.

Rigler, A. (2005): Társadalmi egyenlőtlenségek az infokommunikációs eszközök használatában. (in: Dessewffy T. - Fábián, Z. - Z. Karvalics, L. /szerk./: Internet.hu - A magyar társadalom digitális gyorsfényképe 2., 213-238.)

Roberts, D. F. - Foehr, U. G. (2008): Trends in Media Use. The Future of Children, 18(1), 11-37.

DOI: http://dx.doi.org/10.1353/foc. 0.0000

Roberts, D. F. - Foehr, U. G. - Rideout, V.J. (2005): Generation M: Media in the Lives of 818 Year Olds. Menlo Park, CA: Kaiser Family Foundation, 2005

Robinson, J. P. - Martin, S. (2009): Of Time and Television. The ANNALS of the American Academy of Political and Social Science, 625(1), 74-86.

DOI: http://dx.doi.org/10.1177/0002716209339275

Salvucci, D. D. - Taatgen, N. A. (2008): Threaded cognition: An integrated theory of concurrent multitasking. Psychological Review, 115(1), 101-130.

DOI: http://dx.doi.org/10.1037/0033-295X.115.1.101

Selhofer, H. - Hüsing, T. (2001): The Digital Divide Index - A Measure of social inequalities in adoption of ICT; 2001 
Síklaki, I. (2011): Viszonyulás a tudáshoz. Információs Társadalom, 9(1-4), 155-161.

Silverstone, R. - Haddon, L. (1996): Design and domestication of information and communication technologies. In: Silverstone, R. - Mansell, R. (Eds.) Communication by design. Oxford: Oxford University Press. 44-74.

Schroeder, R. (2010): Mobile phones and the inexorable advance of multimodal connectedness. New Media Society, 12(1), 75-90.

DOI: $\underline{\text { http://dx.doi.org/10.1177/1461444809355114 }}$

Spink, A. - Alvarado-Alvertorio, F. - Narayan, B. - Brumfield, J. - Park, M. (2007): Multitasking information behaviour in public libraries. A survey study. Journal of Librarianship and Information Science, 39(3), 177-186.

\section{DOI: http://dx.doi.org/10.1177/0961000607080420}

Spira, J. B. - Fenituch J. B. (2005): The Cost of Not Paying Attention: How Interupptions Impact Knowledge Worker Productivity (Basex Inc., 2005)

Stephens, K. K. (2012): Multiple Conversations During Organizational Meetings: Development of the Multicommunicating Scale. Management Communication Quarterly, 26, 195-223.

DOI: http://dx.doi.org/10.1177/0893318911431802

Stephens, K. K. - Davis, J. (2009): The Social Influences on Electronic Multitasking in Organizational Meetings. Management Communication Quarterly, 23(1), 63-83.

DOI: http://dx.doi.org/10.1177/0893318909335417

Stephens K. K. - Sørnes J. O. - Rice R. E. - Browning L. D. - Sætre A. S. (2008): Discrete, Sequential, and Follow-Up Use of Information and Communication Technology by Experienced ICT Users. Management Communication Quarterly, 22(2), 197-231.

DOI: http://dx.doi.org/10.1177/0893318908323149

Szabó, A. - Bauer, B. /szerk./ (2009): Ifjúság 2008 Gyorsjelentés (Szociálpolitikai és Munkaügyi Intézet, 2009)

Szabó, A. - Bauer, B. /szerk./ (2005): Ifjúság 2004 Gyorsjelentés (Mobilitás Ifjúságkutatási Iroda, 2005)

Szabó, K. - Hámori, B. (2006): Információgazdaság - Digitális kapitalizmus vagy új gazdasági rendszer. Akadémiai Kiadó, Budapest

Szebenyi, P. (2001): Új korszak kezdete az európai pedagógiában: az iskolai népoktatás követelménye. Magyar Pedagógia 101. évf. 3. szám, 393-410. 
Székely, L. /szerk./ (2012): Magyar ifjúság 2012 kutatás első eredményei 10 kérdés az ifjúságról. Kutatópont, Budapest

Székely, L. - Hajdu, M. - Pintér, R. - Somi, G. (2011): Ügyfélkommunikáció és ügyfélszolgálat az információs társadalomban (in: Nagy, Á. /szerk./ Excenter Füzetek VII. Budapest, 91 p.)

Székely, L. - Szekeres, J. (2011): Internet a családban - az internethasználat családi reguláiról (in: Gabos Erika /szerk/: A média hatása a gyermekekre IV.; Nemzetközi Gyermekmentő Szolgálat Magyar Egyesület, 337-344.)

Székely, L. - Nagy, Á. (2011): Online youth work and eYouth - A guide to the world of the digital natives. Children and Youth Services Review, 33(11), 2186-2197.

DOI: http://dx.doi.org/10.1016/j.childyouth.2011.07.002

Székely, L. - Urbán, Á. (2011): Over the Innovators and Early Adopters: Incentives and Obstacles of Internet Usage (in: Pierson, J. - Mante-Meijer, E. - Loos E. /ed./: New Media Technologies and User Empowerment. Peter Lang, Frankfurt am Main, 195-209.)

Székely, L. (2011): A médiafogyasztás (át)alakulása az ezredfordulótól napjainkig (in: Tófalvy, T. - Kacsuk, Z. - Vályi, G. /szerk./: Zenei hálózatok - Zene, műfajok és közösségek az online hálózatok és az átalakuló zeneipar korában, L'Harmattan, Budapest, 354-367.)

Székely, L. (2010): Internetcsizma az iskolapadon - Esettanulmány egy régi vita margójára. Új Ifjúsági Szemle, 8(4), 79-87.

Székely, L. (2010): Ifjúsági munka virtuális térben (in: Nagy, Á. - Földi, L.- Járosi, É. /szerk/: Ifjúságügy - ifjúsági szakma, ifjúsági munka Módszertani kézikönyv. ISzTMobilitás-ÚMK Budapest. III. 1-56.)

Székely, L. - Nagy, Á. (2010): Virtual Youth Work and eYouth - A Guide to the World of the Digital Natives (in: Excenter Booklets VI., 57 p.)

Székely, L. (2010): Útikalauz a digitális bennszülöttek világába. Új Ifjúsági Szemle, 8(3), 42-63.

Székely, L. - Urbán, Á. (2009): A bevonódás útjai, avagy hogyan kezdtünk internetezni (in: Nagy, Á. /szerk./: Excenter Füzetek I. Budapest, 58 p.)

Székely, L. - Rab, Á. - Nagy, Á. (2008): Virtuális ifjúsági munka (in.: Nagy, Á. /szerk./: Ifjúságügy. Palócvilág - Új Mandátum, Budapest, 420-445.)

Székely, L. (2008a): Fogyasztás, gazdasági helyzet, kultúra, média, infokommunikáció Civil Ifjúsági Jelentés 2006-2007. Új Ifjúsági Szemle, 6(2-3), 67-74. 
Székely, L. (2008b): Youth in information society. (Report On The Hungarian National Youth Policies for Council of Europe (EC) Institute For Political Science Of The Hungarian Academy Of Sciences) Hungarian New Youth Review, 4(1), 79-86.

Székely, L. (2007): Valódi virtuális közösségek - recenzió. Jel-Kép 2007/3, 91-97.

Székely, L. (2007): A jövő médiafogyasztói. Új Ifjúsági Szemle, 5(1), 82-92.

Székely, L. (2006): Másvilág - Fiatalok az információs társadalomban. Új Ifjúsági Szemle, $4(3), 35-45$.

Székely, L. (2005): Magyar szó a végeken. Új Ifjúsági Szemle, 3(2), 31-57.

Tari, A. (2010): Y generáció. Klinikai pszichológiai jelenségek és társadalomlélektani összefüggések az információs korban. Jaffa Kiadó, Budapest.

Toffler, A. (2001): A harmadik hullám. Információs Társadalom A-tól Z-ig sorozat. Typotex, Budapest

Turkle, S. (2011): Alone Together: Why We Expect More from Technology and Less from Each Other Basic Books; 1 edition (January 11, 2011)

Turner, J. W. - Reinsch, N. L. (2007): The Business Communicator as Presence Allocator: Multicommunicating, Equivocality, and Status at Work. Journal of Business Communication, 44(1), 36-58.

DOI: http://dx.doi.org/10.1177/0021943606295779

Urbán, Á. - Székely, L. (2009): Multitasking - new way of communication and media consumption among young people (in: Alan Albarran, Paulo Faustino and Rogério Santos /ed./: The Media as a Driver of the Information Society - Economics, Management, Policies and Technologies, MediaXXI/Formalpress - Publicações e Marketing Lda, and Universidade Católica Editora, Unipessoal, Lda, 2009)

Urbán, Á. (2007): Az új médiaszolgáltatások terjedése. Információs Társadalom, 7(2), 31-53.

Urbán, Á. (2004): Az új média szolgáltatások piaca. Ph.D. disszertáció. Budapesti Corvinus Egyetem, Budapest

Vandewater, E. A. - Lee, S-J. (2009): Measuring Children's Media Use in the Digital Age: Issues and Challenges. American Behavioral Scientist, 52(8), 1152-1176.

DOI: http://dx.doi.org/10.1177/0002764209331539

Vega, V. (2009): Media-Multitasking: Implications for Learning and Cognitive Development in Youth. Background Paper for the Seminar on the Impacts of Media Multitasking on Children's Learning \& Development. Stanford Universitiy, 2009 
Wallis, C. (2010): The impacts of media multitasking on children's learning and development: Report from a research seminar, New York, NY: The Joan Ganz Cooney Center at Sesame Workshop.

Wang, Z. - Tchernev, J. M. (2012): The "Myth" of Media Multitasking: Reciprocal Dynamics of Media Multitasking, Personal Needs, and Gratifications. Journal of Communication, 62(3), 493-513.

DOI: http://dx.doi.org/10.1111/j.1460-2466.2012.01641.x.

Wartella, E. - Huston, A. C. - Rideout, V. - Robb, M. (2009): Studying Media Effects on Children: Improving Methods and Measures. American Behavioral Scientist, 52(8), 1111-1114.

DOI: http://dx.doi.org/10.1177/0002764209331536

Wellman, B. - Guila, M. (1999): Net Surfers Dont Ride Alone: Virtual Communities as Communities. (in: Smith, M. A. - Kollock, P. /ed./: Communities in Cyberspace, London: Routledge. 168-194)

Wirtz, B. W. (1999): Convergence processes, value constellations and integration strategies in the multimedia business. The International Journal on Media Management, 1(1), 14-22.

Z. Karvalics L.: Lyuk a falon - Közoktatás és a gyermek az információs társadalomban. (megjelenés alatt)

Z. Karvalics, L. (2009): Az iskola az információs társadalomban Az oktatás „újralátogatott” világválsága (Oktatáskutató Intézet, 2009. június 17.) http://www.ofi.hu/tudastar/nyitott-iskola-tanulo/iskola-informacios

Z. Karvalics, L. (2007a): Information society - what is it exactly? (The meaning, history and conceptual framework of an expression) (in: Pintér, R. /ed./: Information society coursebook. Gondolat - Új Manátum, 29-46.)

Z. Karvalics L. (2007b): Információs társadalom - a metakritika hiábavalósága és gyötrelmessége. Információs Társadalom, 7(4), 107-123.

\subsection{JELENTÉSEK, ONLINE CIKKEK}

Beam, J. (2011): How Do Employers Monitor Internet Usage at Work? (http://www.wisegeek.com/how-do-employers-monitor-internet-usage-at-work.htm)

Burst Media (2007): Go Online to Reach the "Online At Work” Audience (http://www.burstmedia.com/pdfs/research/2007 11 01.pdf) 
eMarketer (2006): An Imminent Shift in Consumer Electronics? October 3.

Fábián, Z. - Galácz, A. - Gerhardt, E. - Körner, J. - Kollányi, B. - Ságvári, B. - Székely, L. (2007): A digitális jövő térképe - Gyorsjelentés a World Internet Project 2007. évi magyarországi kutatásának eredményeiről. ITHAKA, 80 p.

Fábián, Z. - Galácz, A. - Gerhardt, E. - Kollányi, B. - Ságvári, B. - Székely, L. (2007): A digitális jövő térképe - Gyorsjelentés a World Internet Project 2006. évi magyarországi kutatásának eredményeiről. ITHAKA, 84 p.

Fisher, K. (2005): Web surfing costing businesses nearly $\$ 200$ billion? (http://arstechnica.com/old/content/2005/07/5119.ars)

GfK (2008): Távközlési szolgáltatások használata az üzleti és intézményi felhasználók körében - Kutatási jelentés az NHH részére, 2008

Hopkins, L. (2008): Deacons Law Firm - 2008 Social Networking Survey (http://www.leehopkins.net/2008/05/23/deacons-law-firm-2008-social-networkingsurvey/)

Kirn, W. (2007): The autumn of the multitaskers. The Atlantic, 2007. November (http://www.theatlantic.com/magazine/archive/2007/11/the-autumn-of-themultitaskers/306342/)

Lawler, R. (2010): Nielsen: Media Multitasking Catches On (http://gigaom.com/video/nielsen-americans-watching-more-tv-than-ever/)

Miller, P. (2012): Lonely, but united: Sherry Turkle and Steven Johnson on technology's pain and promise, The Verge 2012.10.05.

(http://mobile.theverge.com/2012/10/5/3459938/sherry-turkle-and-steven-johnsonon-technology-pain-promise)

MyJobGroup.co.uk (2010): Social media in the workplace (MyJobGroup.co.uk, 2010) (http://www.myjobgroup.co.uk/socialmediawhitepaper/SocialMediaWhitepaper.pdf)

Websense, Inc. (2005): \$178 Billion in Employee Productivity Lost in the U. S. Annually Due to Internet Misuse

(http://files.shareholder.com/downloads/WBSN/0x0x155638/8d693e02-a2f3-48549edd-a5a3e7f51c94/285208.pdf)

Menedzsment Fórum (2008): Tízből hét főnök száműzi a közösségi oldalakat a munkahelyről (http://www.mfor.hu/cikkek/43797.html)

nVision (2007): Media Consumption in a Wireless World. How the new 'convergence culture' is changing television, radio and newspapers as we know them.

Ofcom (2007) [Office of Communications]: Communications Market Report. 
Olswang (2006): Convergence Consumer Survey 2006

OpenDNS® (2011): OpenDNS® 2010 Report Web Content Filtering and Phishing (http://www.opendns.com/pdf/opendns-report-2010.pdf)

Ponemon Institute (2010): Web 2.0 Security in the Workplace Study of IT practitioners in the United States, United Kingdom, Australia, France \& Japan; Ponemon Institute LLC 1 June, 2010

Robert Half Technology (2011): SOCIAL WORK? More Companies Permit Social Networking on the Job, Robert Half Technology Survey Reveals (http://rht.mediaroom.com/2011SocialMediaPolicies)

Special Eurobarometer (2012): E-Communications Household Survey European Commission, Directorate-General for Communication (DG COMM "Research and Speechwriting" Unit)

The Multi-Screen Marketer Interactive Advertising Bureau (IAB) Econsultancy.com Ltd 2012

(http://www.iab.net/media/file/The Multiscreen Marketer.pdf)

Urbán, Á. - Székely, L. (2007): Kutatói kihívások a kommunikáció- és médiakutatásban (in: Infinit Hírlevél 2007.01.26.)

Wallis, C. (2006): The Multitasking Generation. Time. March 27.

Z. Karvalics, L. (2006): Computers in Libraries (in: Infinit Hírlevél 2006.04.01.) 


\section{FÜGGELÉK}

A függelékben három különböző időpontban készült adatfelvétel (World Internet Project 2001-es és 2007-es adatait, illetve a Lakossági Médiafogyasztás Kutatás 2012) eredményeit mutatom be a médiafogyasztás mennyiségével, a különböző médiumok fontosságával és a párhuzamos médiafogyasztással kapcsolatban. (Utóbbi esetben 2001es adatok híján a 2007-es és 2012-es adatokra támaszkodva.)

$\mathrm{Az}$ internethasználat mennyisége és az internet fontosságának megítélése az ezredfordulótól napjainkig gyökeresen megváltozott, az internet elterjedése mellett az internettel töltött idő és az internet fontosságának megítélése összességében is növekedett és az életkorral való kapcsolata is erősödött.

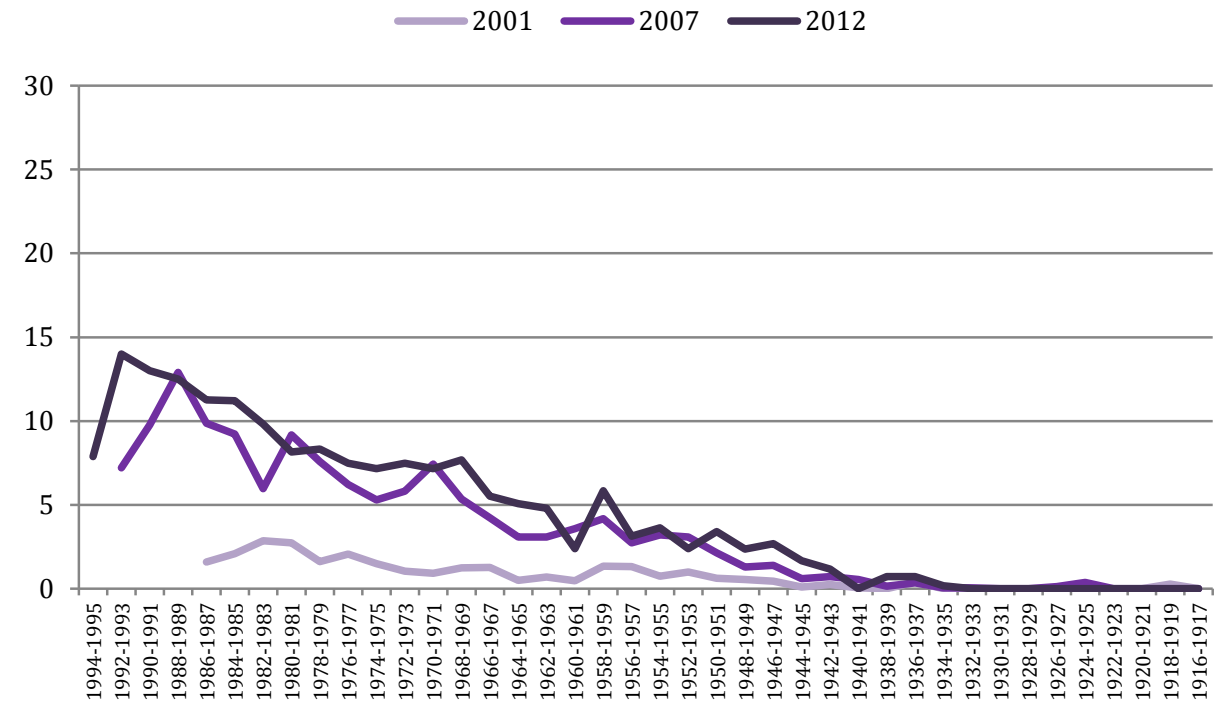




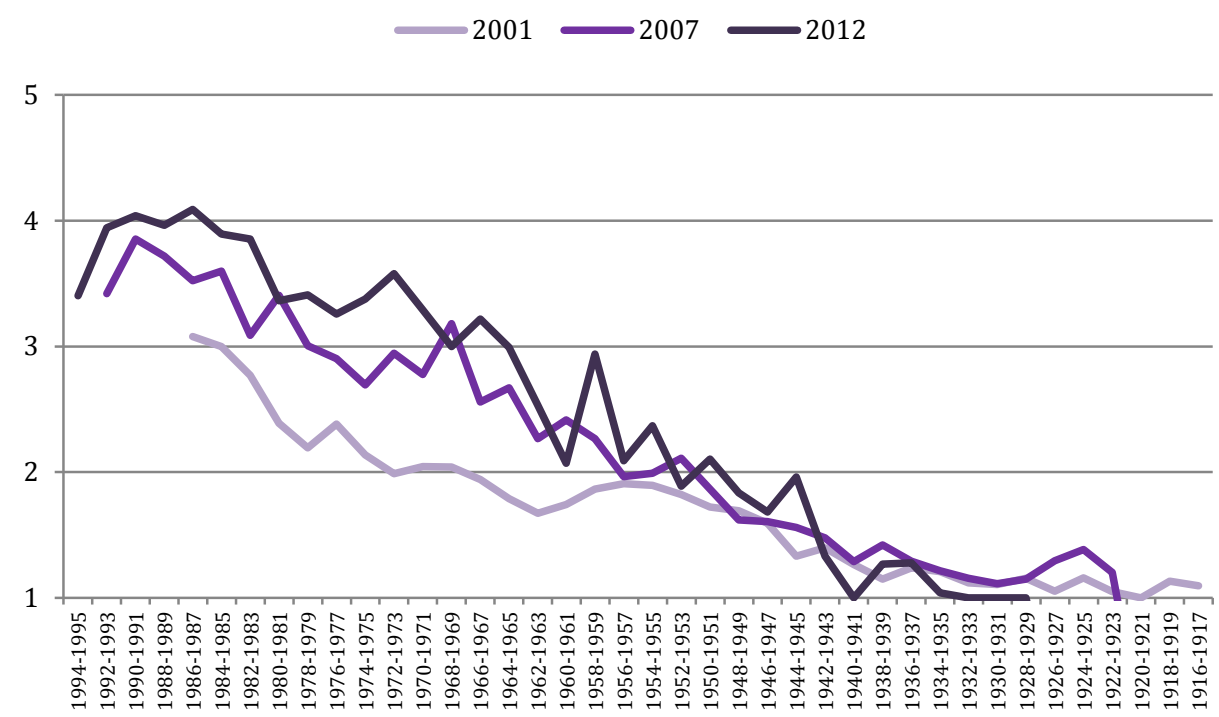

A televízió szerepe alapvetően nem változott 2001 és 2012 között, hasonló fogyasztási struktúra és fontosság látszik az adatokból. A tévézés tekintetében nem láthatunk olyan erős kapcsolatot az életkorral, mint az internet esetében, azonban így is kirajzolódnak a fő tendenciák, az életkor növekedésével egyre fontosabbá válik a televízió, ezt mutatják a fogyasztási és a szubjektív megítélés adatai egyaránt.

49. ábra: Televízió-nézés mennyisége (World Internet Project 2001; 2007 és Lakossági Médiafogyasztás Kutatás 2012)

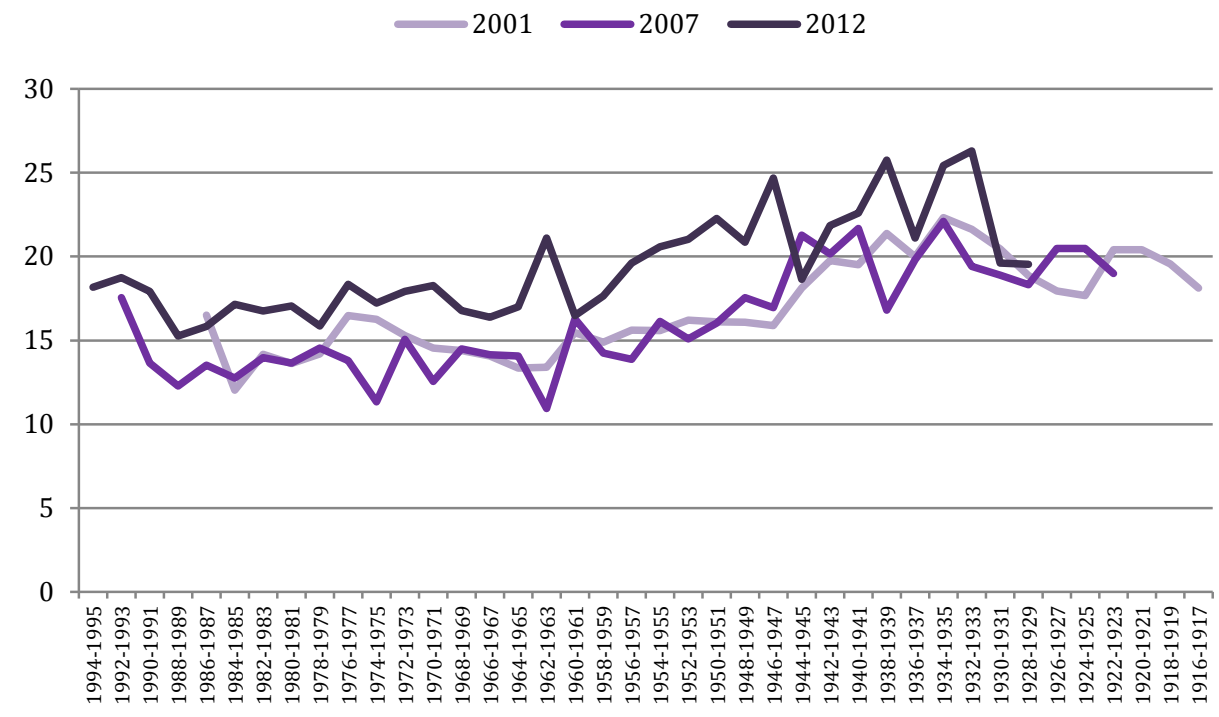




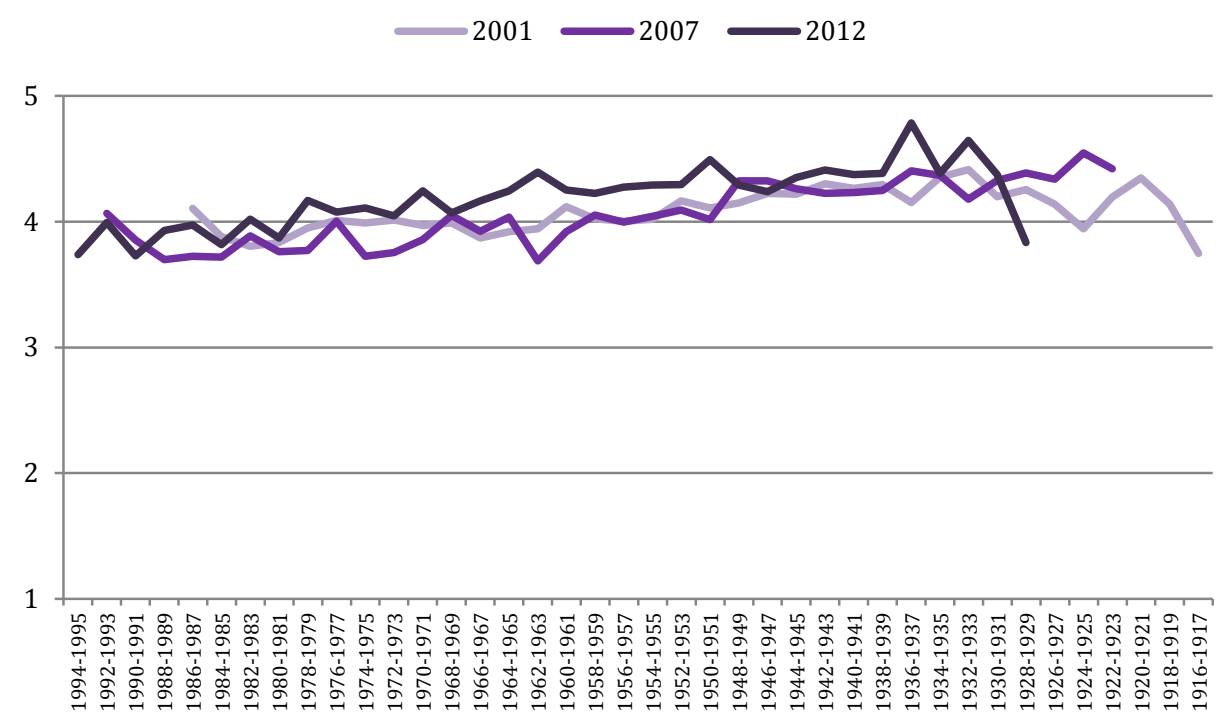

A három időpontban történt adatfelvétel jól mutatja a rádió térvesztését folyamatos csökkenést figyelhetünk meg a fogyasztás mennyiségében és leértékelődést a fontosság megítélésében. A rádió szerepe az életkor növekedésével egy darabig párhuzamosan halad, majd a '80-as évek elején, a '70-es évek végén és a születetteknél idősebb esetében inkább stagnál.

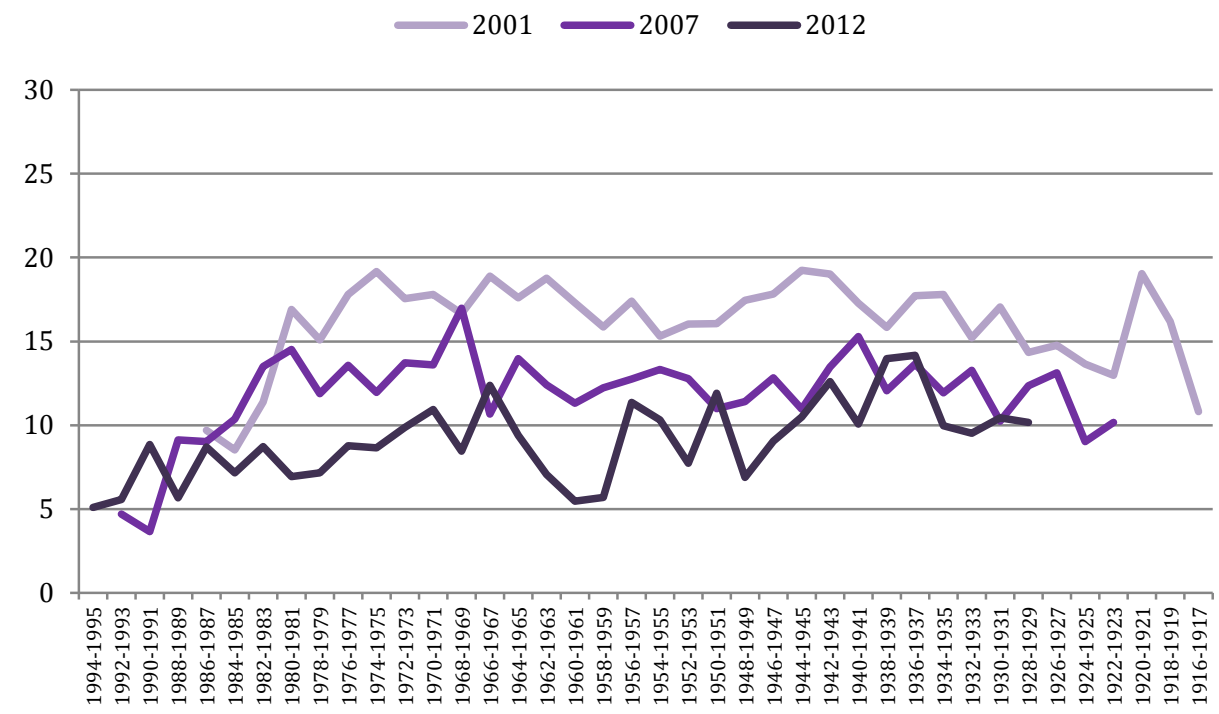




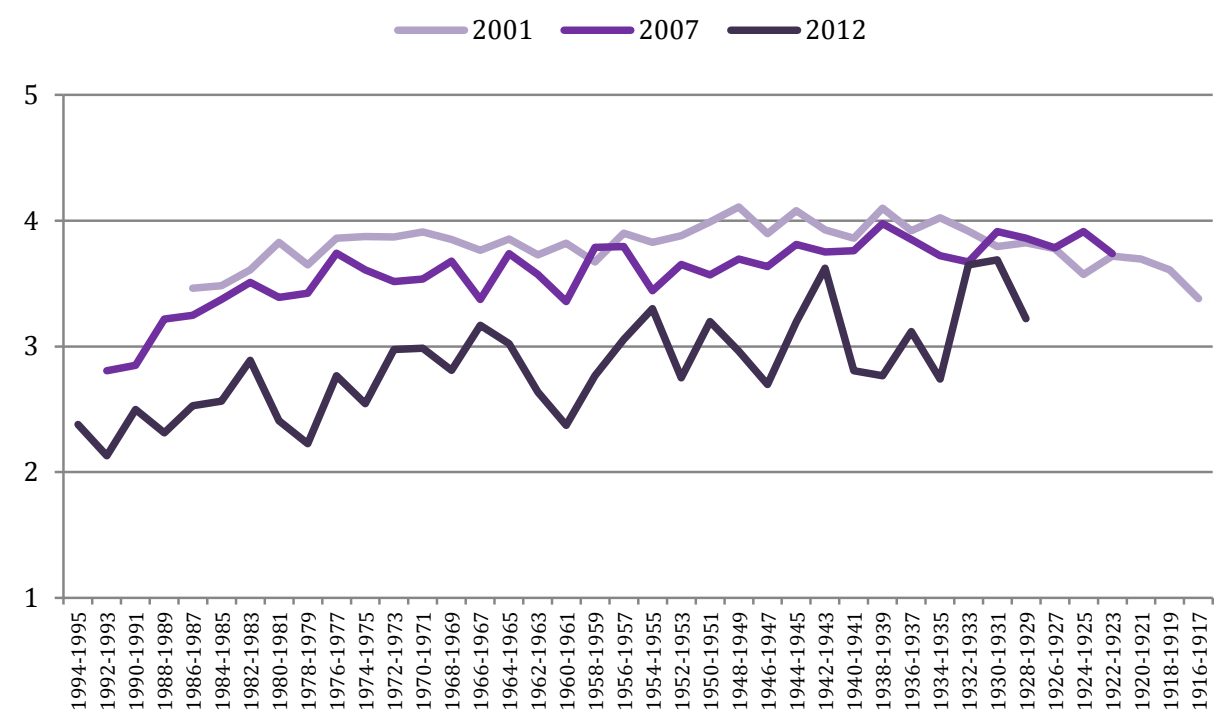

A nyomtatott sajtó fogyasztásának alacsony mennyisége valamivel tovább csökkent az ezredfordulóhoz képest. Az életkorral való kapcsolatát - legalábbis, ami az újságok fontosságának megítélését illeti - három szakaszra lehet bontani: a '70-es évek közepénvégén születetteket megelőző generációra, a második világháború után és a '70-es évek vége előtt születettek, illetve a második világháború előtt születettek generációjára.

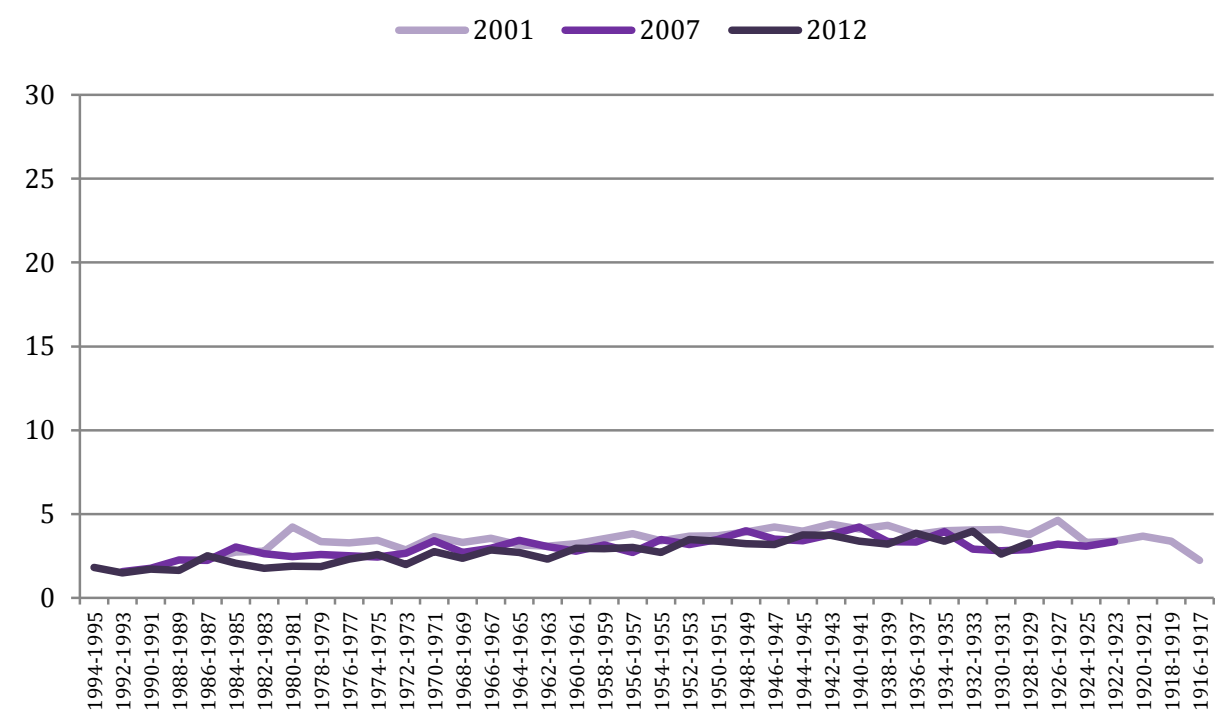


54. ábra: Újságok fontossága (World Internet Project 2001; 2007 és Lakossági Médiafogyasztás Kutatás 2012)

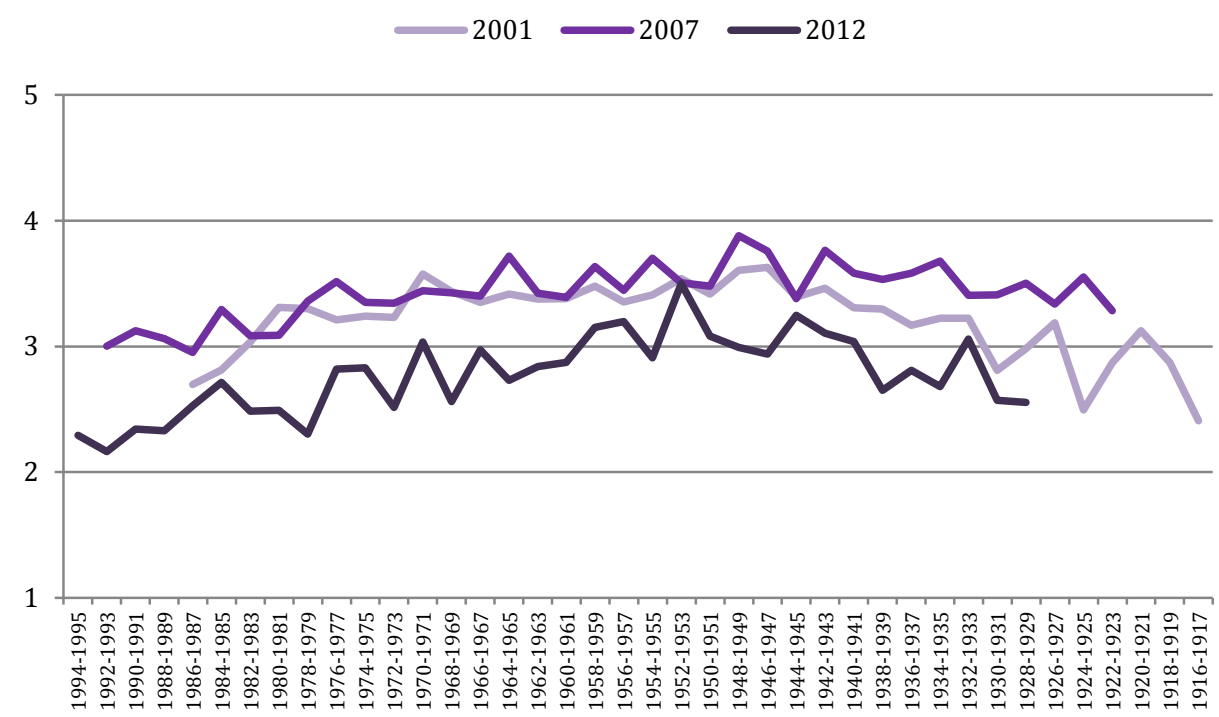

A nyomtatott sajtóhoz hasonlóan a könyvek szerepe is visszaesést mutat 2001 és 2012 között. A könyvolvasás mennyisége, illetve a könyvek fontossága nem mutat erős kapcsolatot az életkor tekintetében, kivéve a második világháború előtt születettek generációját, ahol jellemzően alacsonyabbra értékelik a fontosságát.

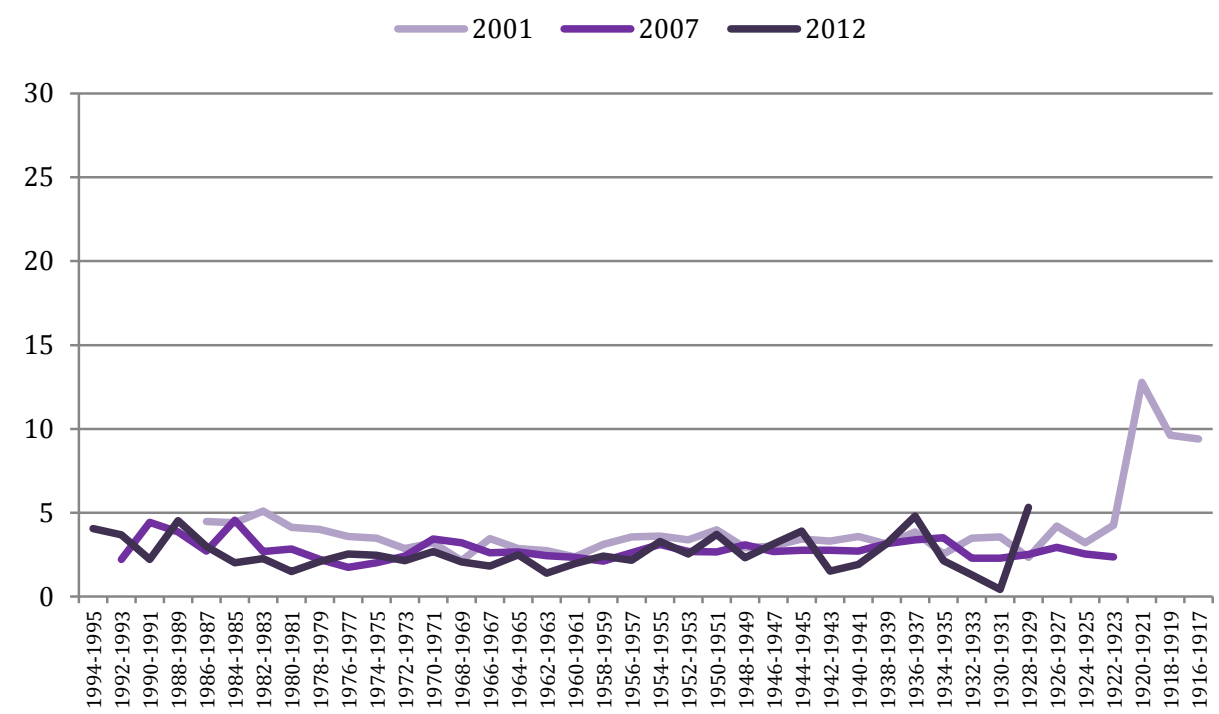




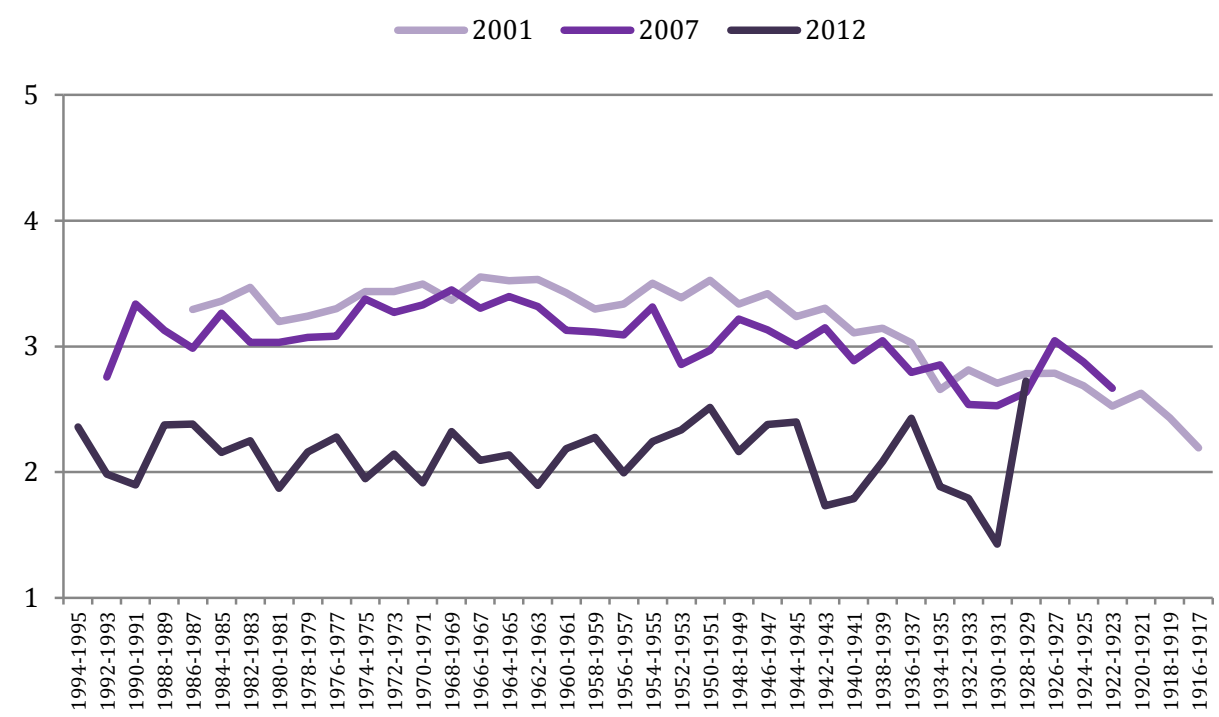

A párhuzamos médiafogyasztás csak a két utóbb készült kutatás adatbázisán vizsgálható (korábban ugyanis nem szerepelt a kérdőívben erre vonatkozó kérdés). Az alábbi ábrán látható, hogy a 2007 és 2012 között eltelt öt évben folyamatosan növekedett a párhuzamos médiafogyasztás, elsősorban a középgeneráció körében. Ezzel együtt az életkor továbbra is erős magyarázója a multitaskingnak, minél fiatalabbakat vizsgálunk annál valószínúbb a párhuzamos médiafogyasztás.

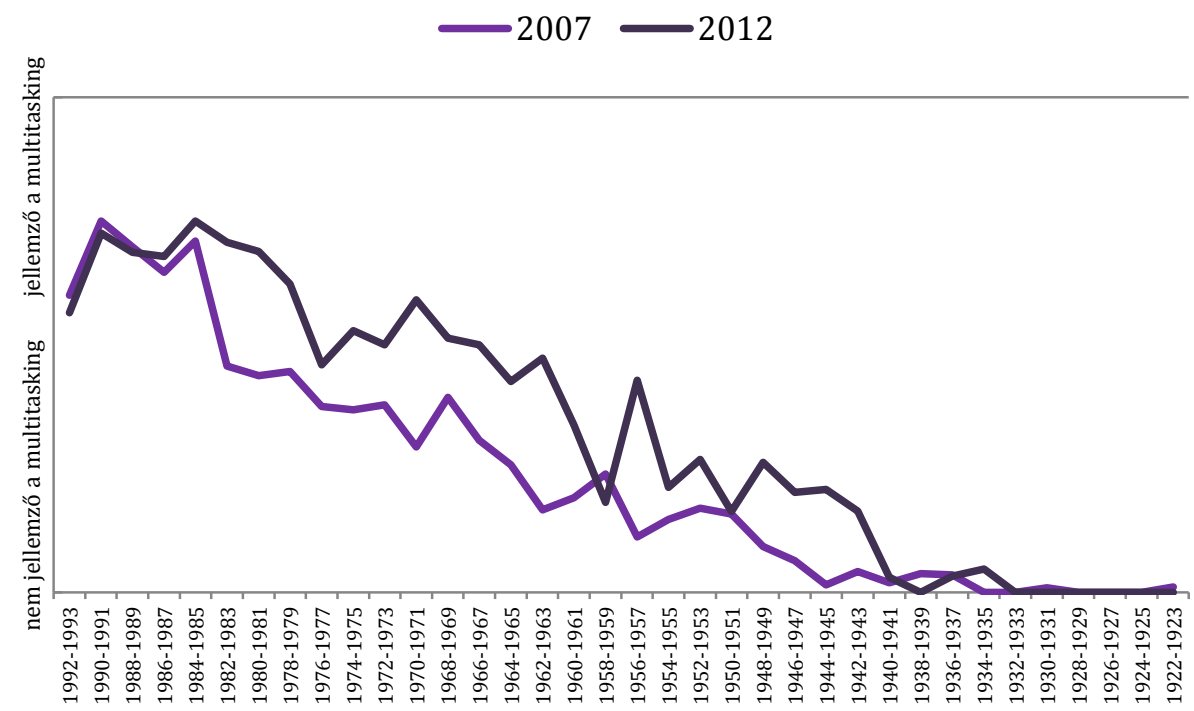


A médiafogyasztás különböző ismérvei szerint készített regressziós modellek - néhány esettől eltekintve - általában csekély magyarázóerővel bírnak. Kivételt képez a zenehallgatás, az internetezés, illetve a párhuzamos fogyasztás. Általánosságban elmondható, hogy a generációs hatást tesztelő modellek magyarázóereje csekély mértékben erősebb, mint az életkori hatást tesztelő egyszerű lineáris modellek magyarázóereje, azonban a különbségek olyan kicsik, hogy ezek alapján nem vethetjük el egyik megközelítést sem.

27. táblázat: Regressziós modellek magyarázóereje

Médiafogyasztás

Könyvolvasás

Újságolvasás

Rádióhallgatás

Zenehallgatás

Tévénézés

Internetezés

Könyvek fontossága

Újságok fontossága

Rádió fontossága

Televízió fontossága

Internet fontossága

Multitasking
Életkori hatás (Adjusted

R Square)

0,01

0,04

0,03

0,11

0,04

0,16

0,01

0,02

0,05

0,07

0,32

0,20
Generációs hatás (Adjusted R Square)

0,01

0,05

0,06

0,11

0,05

0,19

0,01

0,04

0,07

0,08

0,33

0,20 